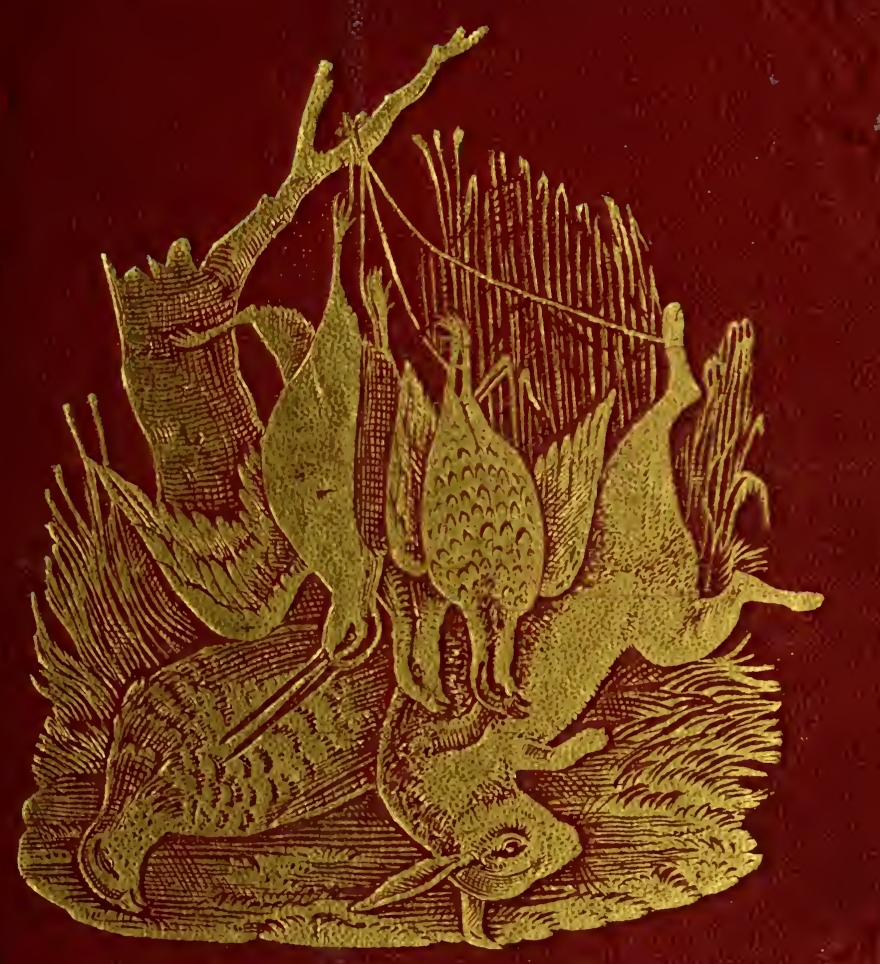




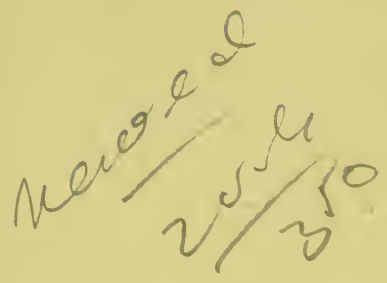

\section{THE UNIVERSITY}

\section{OF ILLINOIS}

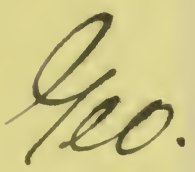

LIBRARY

799

$+41 \mathrm{fr}$

Sine

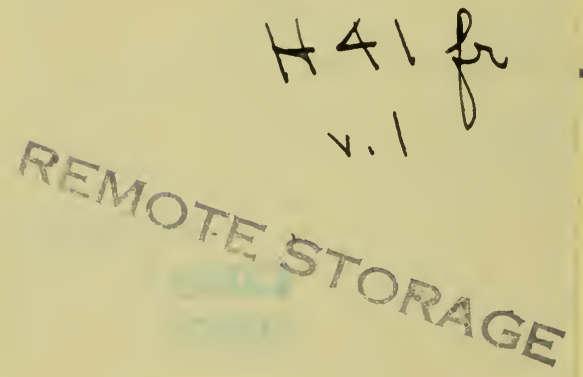


NOTICE: Return or renew all Library Materials! The MInimum Fee for each Lost Book is $\$ 50.00$.

The person charging this material is responsible for its return to the library from which it was withdrawn on or before the Latest Date stamped below.

Theft, mutilation, and underlining of books are reasons for disciplinary action and may result in dismissal from the University.

To renew call Telephone Center, 333-8400

UNIVERSITY OF ILLINOIS LIBRARY AT URBANA-CHAMPAIGN

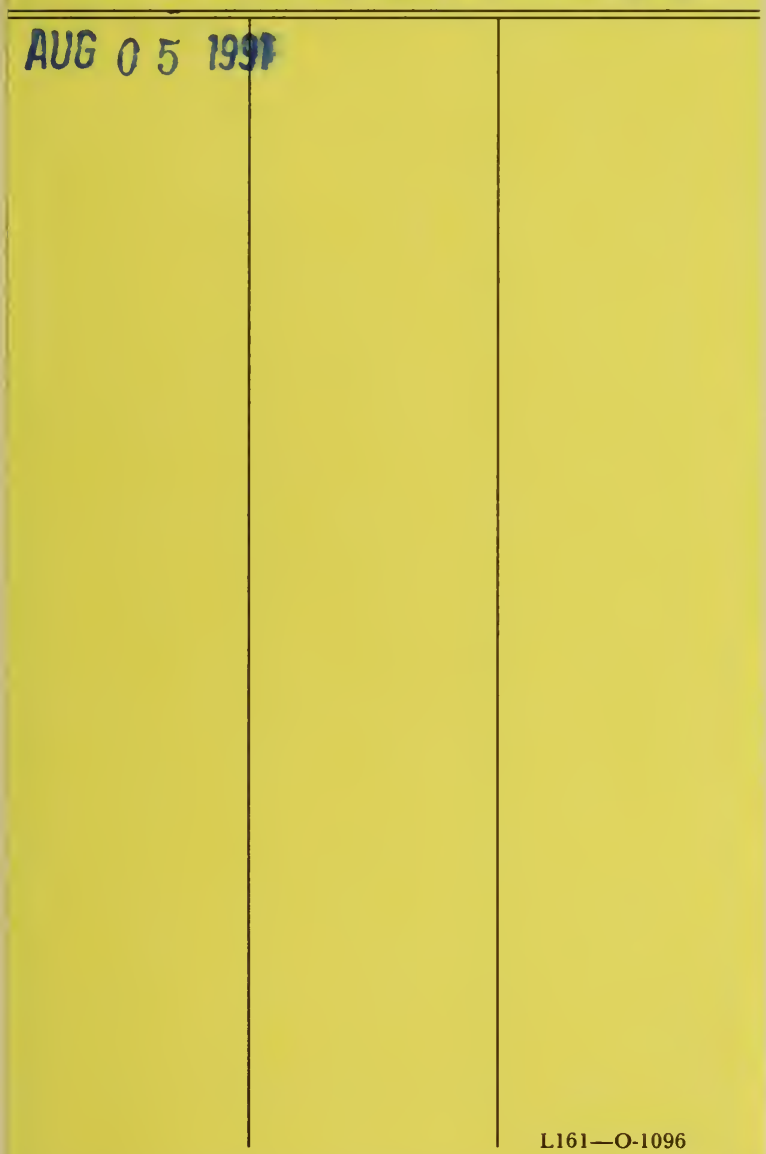




Digitized by the Internet Archive in 2015 



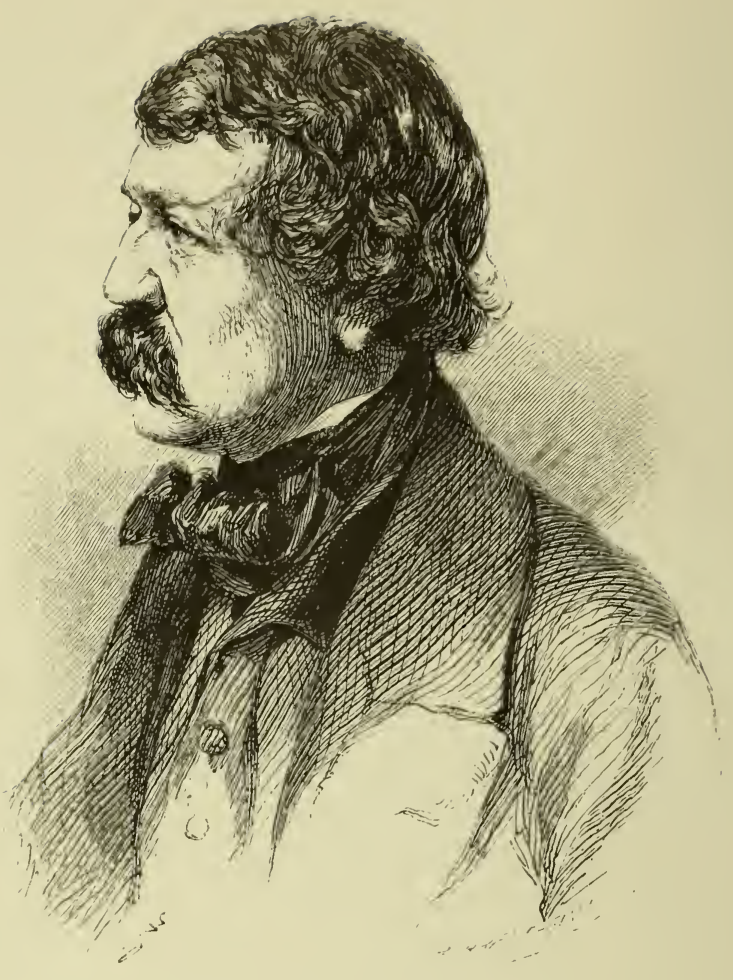

FPAXK FOIFSTER.

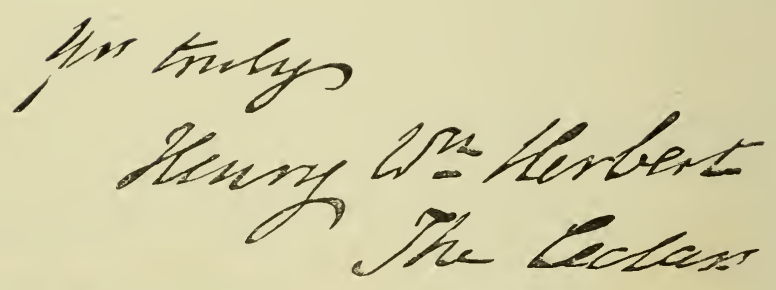




\section{FRANK F O RESTER'S}

\section{F I E L D S P O R T S \\ OF TIT:}

U N I TED STATES

AND

BRITISH PROVINCES OF NORTH AMERIOA.

BY

\section{FIF RY WIIIIAM HERBER'T,}

AUTUOR OF FRANK FORESTER'S "FISII AND FISHING," "HORSE AND HORSEMANSUIP" "TLE COZ: PLETE MANUAL FOR YOUNG SPORTSUF:X," l'TU.

\section{There is exhilaration in the chase-}

Not bodily only.

It is a mingled rapture, and we find

The bodily spirit monnting to the mind.

Sir Egertox Brydgris.

NEW EDITION, CONTAINING NUMEROUS CORRECTIONS AND ADDITIONB, WITH ILLUSTRATIONS FROM NATURE, AND A BRIEF

MEMOIR OF THE AUTHOR.

I N T W O V V L U M E S.

VOL. I.

NE T YORK:

PUBLISHED BY, W. A. TOWNSEND \& ADAMS.

1868 . 
Entered according to en Act of Congress, in the year 1848, BY STRINGER AND TOWNSEND.

In the Clerk's Ofice of the District Court for the Southern District of New-York

C. A. ALYORD, Printer:

No. 15 Vandewater Street, N. I 


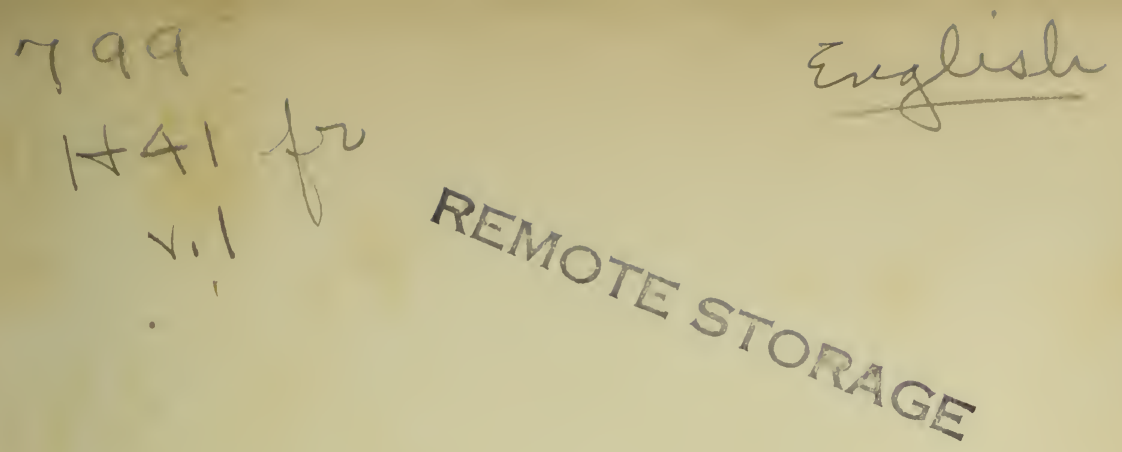

To

COLON HL WA DE HAMI'TON,

OF "THE WOODLANDS," SOUTH CAROLINA,

TH I S W O R K O N T H E

तfield Sports of the oruted States, $\triangle N D$

BR̨ITISH PROVINCES OF NORTH AMERICA,

I8

VEKY RESPECTFULLY DEDICATED, AS A TRIBUTE OF HOMAGE TO TUL

FIRST SPORTSMAN IN THE LAND

BY HIS OBD'T SERVANT,

FRANK FORESTER. 


\section{LIST OF ILLUSTRATIONS \\ (1) บ yolume (ํ)}

PORTRAIT OF THE AUTHOR, . . . . . . Frnntispiece.

Rocky Mountain Sheep and Gonts . . . . . . 32

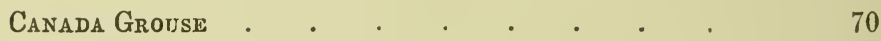

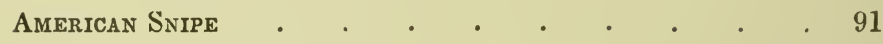

Green and Blue-Winged Teal . . . . . . . 119

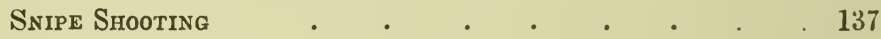

AMERICAN WOODCOCR $\quad . \quad$. . . . . 169

Ruffed Grouse . . . . . . . . 249

American Quatl • • . . . . . . . 263 


\section{CONTENTS OF VOLUME ONE.}

MEMOIR OF THE AUTHOR, . . . . . . pp. xi-xlvi

INTRODUCtory OBSERVATIONS . . . . 11

The Game of North America . 30

Dpland Shooting of the Northehn States and British

Provinces . . . . . . . . . . 4

The Pinnated Grouse _ . . . . . . . . 49

The Ruffed Grouse $\quad$. . . . . . . . 0.1

The Canada Grouse . . . . . . . . . 71

American Quail • . . . . . . . . 80

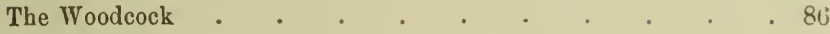

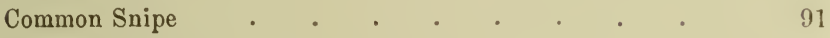

Bartram's Tatler . . . . . . . . . 94

The American Hare .

The Northern Hare $\quad$. $\quad$. . . . . . 108

The Mallard . . . . . . . . . 10!

The Dusky Duck . . . . . . . . . 110

The Blue-Winged Teal ․ . . . . . 115

The Green-Winged Teal . . . . . . . 119

The Wood Duck-Summer Duck . . . . . 122

The Pintail Duck . . . . . . . . . 128

Upland Shooting of the Eastern and Mrdde States and of

the British Provinces . . . . . . . 134

Spring Snipe Shooting • • • . . . . . 137

Summer Woodeck Shooting • • • • . . 169

Upland Plover Shooting . . . . . . . 201

Antumn Cock Shooting $\quad$ • $\quad$. $\quad$. $\quad$. . . 209 
viii

CONTENTS.

Quail Shooting . . . . . . . . . 219

Ruffed Grouse Shooting . . . . . . . 240

Grouse Shooting . . . . . . . . . 248

Autumn Shooting . . . . . . . . 263

Rail ; and Rail Shooting . . . . . . . 274

Rail Shooting . . . . . . . . . . 293

Duck Shooting on Inland Waters . . . . . 299

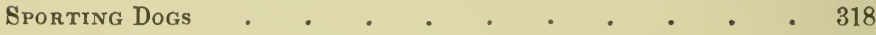

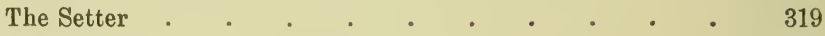

The Pointer . . . . . . . . 334

The Cocking Spaniel . . . . . . . 338

Kennel Management _ . . . . . . 841

Field Management of Dogs . . . . . . 300 


\section{A DVERTISEMENT}

TO THE EIGHTH EDITION.

I HAve little to say in the Preface to the eighth edition of the following work on Field Sports, first issued in 1849 ; my reasons for producing it, at this moment, will be found in the body of the book itself; but, once for all, it appeared to me that such a work was needed, at this juncture, and that its publication might possibly tend, in some small degrec, to avert the impending doom which seems to have gone forth from the democracy of the land against game of all sorts.

No one abler, or elder, seemed willing to stand forth; so "with all my imperfections on my head," I have ventured mysclf as the champion of American Sport and Sportsmanship; and-"what is writ is writ, would it were worthier !"

I have here, especially and before aught else, to express my obligations for what I have borrowed-the generic distinctions namely, and descriptions of the form, measurement, and plumage, of all the winged game of the Continent-from those distinguished ornithologists and good sportsmen, Mr. AuduBoN and Mr. Granud, to whose " Birds of America," and "Birds of Long Island," I am greatly indebted. I have not scrupled, moreover, to quote largely, on occasion, from Wilson's "American Ornithology," De KAY's " Natural History of New York," and Godman's " American Natural History," - and to all these gentlemen I beg to express the high sense I feel, of the aid I have 
derived from their excellent works. To my friend, William T. Porter, I need not apologise for the two or three pages I have borrowed from his admirable edition of "Kawker on Shooting," as he would pardon, doubtless, a heavier offence to a fellow worker in the same honorable field with himself.

For the illustrations designed by myself, from living or stuffed specimens, I am greatly indebted to Mr. BeLL, the eminent taxidermist and naturalist, who kindly laid open his cabinet for my use.

Since issuing my first edition, many criticisms-some very correct and courteous, others just as incorrect, uncandid, and ungentlemanly-have led me to review some of my opinions; and those which are found incorrect, will be found entirely altered and rewritten. This is the case with the article on the Pinnated Grouse, concerning which I have obtained much valuable information from an eminent Western sportsman, which will be found embodied in this edition.

A tour to the North-West and the Great Lakes has enabled me to give some farther information regarding that very interesting region; and much communion during this spring with a very well known Prairie and Rocky Mountain Hunter, Mr. T. M. Adams, of Independence, Missouri, has confirmed me in some of my views, and enabled me to correct errors in others in relation to the Wild Sports of the West.

This said, nothing remains but to express my hope, that my labors may be not wholly vain, and that my doctrines may meet the favorable censure of those, for whose use they are intendedthe Sportsmen of America.

\section{HENRY WILLIAM HERBERT.}

THE above preface is the latest prepared by Mr. Herbert, while anticipating the pleasure of issuing this revised edition, shortly prior to his suddeu decease. The index also, has been carefully adapted to the numerous add:tions in the work, and is now believed to be both accurate and complete. 


\title{
A FEW MEMOIRS
}

OF

\section{HENRY WILLIAII HERBERT,}

\author{
BETTER AND MORE FAMILIARLY KNOWN AS \\ "F R A N K F O R ESTER ."
}

The web of our life is of a mingled yarn, good and ill together: our virtues would be proud if our faults whipped them not, and our crimes would despair if they were not cherished by our virtues."-SHAKESPEARE.

[THE publisher intended to have availed himself of the pleasing pen of one of Mr. Herbert's most intimate and most esteemed friends, the late William T. Porter, Esq., the popular editor of the "Spirit of the Times," as the best qualified and most suitable biographer of the departed "Frank Forester." Mr. Porter, however, being in feeble health, the following sketch was prepared by a mutual friend of all the parties, with the intention of obtaining Mr. Porter's approval as a prefix. In the mean time, a verification occurred of the solemn proverb, "Man proposes-God disposes." William T. Pcrter himsclf is now numbered amorg those who have "gone before."

The publisher is enabled to say, however, that the manuscript of the following sketch has been examined by several of the most prominent associates of both the deceased gentlemen, connected with either the Press or the Turf, and it has been honored with their entire and most cordial approbation.]

AFTER the injunction of "silence," so earnestly implored by the unfortunate-infelicissimus, most unfortunate-gentleman whose real and assumed names are here mentioned, there may, possibly, be some appearance 
of presumption, or disrespect, in making any attempt at a relation of the principal incidents in his life.

Still, as "Frank Forester," the lover of Nature, the charming writer, the Shakespeare of sporting literature, Herbert's name and fame have now become a species of American public property, as it were, in which every person using the English language takes a hearty interest; and, without intending any disregard to the personal wishes of their dear, departed friend-for such his readers all feel and know him to be-his spiritual life and his literary influence have now commenced to shine forth in their true glory, and possess a greater hold than ever upon the public mind, as if enough never could be written or printed concerning so versatile and fascinating an anthor.

Yes, indeed; by the matchless works Herbert has left to speak for him, he is with us more than ever-in spirit - upon the hill-top, in the flowery dell, tracing the sides of mountain brooks from bright and breezy eminences, or holding lofty communion with Nature among the leafy arches and solemn shades in our glorious old woods. As a writer, he has stamped the current impress of his genius upon a young and confederated nation, just beginning to find out its vast possessions in topography and resources, yielding to its inhabitants almost every variety of climate and production. "Frank Forester," with his pen, accompanies us like some well-experienced surveyor, walking about with a divining rod. "Our Frank" does more. He pleasantly introduces us to this, that, or the other -whatever may be most worthy of observation-in earth, air, or water. He points out how to cherish and preserve what an all-bountiful Providence has in store for the active, the patient, or the resolute. He is the "Peter Parley" of his delighted followers. We incontinently shoulder our smooth-bore, lug the knapsack, or continue 
to hold a fishing-rod with both hands, perhaps, even if some attendant mosquitoes are busily digging into our cuticle. We feel fairly enlisted, with all our manhood. We could follow such a leader as Herbert to any Sebastopol, or through any Dismal Swamp. Health and activity would thus give Mercury's wings to our heels, securing a firm colhesion for our brains; and, in town or country, in house or field, while the English language goes on growing in grace or grandeur, the fame and influence of Henry William Herbert must be ever present among our household sentiments and familiar conversations, especially as not one of his writings can be found to contain any improper tendencies. No wonder that the name of "Frank Forester" is already ranked among the most endearing of our "household words." Wherever we may go, the spirit of this instructive and pleasing writer seems to be with us. If we only look out upon the road, or go to the stable, we are reminded of Herbert's influence as soon as our eyes rest upon a horse. The horse itself has advanced in comfort and civilization, so to speak, although he may never have known the benefactor of his race, perhaps, in the flesh-never had an opportunity to trustingly rest his nose on Herbert's shoulder. But, Herbert has reached that horse. The genial spirit of "Frank Forester" has penetrated and dispersed the dark days of mismanagement, whispering a good word or two in season, among the right parties, appealing to the natural affections of the noble animal, and calling forth the loyal response of all the gallant creature's fidelity and endurance.

This is no exaggeration. The length and breadth of this glorious land are now filled with the refreshing practical philosophy taught by "Frank Forester." We say this not as a mere figure of speech; we assert it as a fact, honorable as well to the reading public as to the author 
they thus delight to honor. By the spiritualization of intellect in Herbert's writings, even the largest and wildest of our American forests may become organized into classification, as if one grand cathedral for the worship of Nature in the study of natural history. The sunlight of intelligence seems to come over the mountain-tops, and stream in through the clearings, lake shores, or oak openings, as if the trees it illuminates were architectural windows, depicting sacred subjects for our contemplation upon stained glass, and mellowing our souls with a sublimity of thought ascending like incense from an altar which consumes all inordinate desires and city-bred artificialities. Surely then, no person who has ever read Herbert's works would intentionally mar or interfere with the legitimate operations of their genial and refining influence.

No; the hand now tracing these lines obeys the mind of a friend who would not, for worlds, be guilty of disregarding the last wishes of so delightful (to him) a companion, and so completely qualified a public instructor as Henry William Herbert. As the priest wears a ring in token of marriage with the Church, so Herbert, with his pen in hand, was always faithful and constant to his public. A man so wayward-so peculiar-so often troublesome, apparently, to those who had actual dealings with him, is but rarely met with; and yet, he always had one uniform degree of devotion to his readers. Even this was more tacit than expressed, but it was, nevertheless, uniform and consistent from the time he first began to write for the public eye. Perhaps we might say, by way of metaphor, that Herbert's only real wife was his public. Certain it is that constant devotion on his part, and increasing kindness on the other, has brought about a union of such indissoluble happiness as deprives death of nearly all its sting, and leaves the grave itself no victory. 
In accordance with and in response to a national-we might almost say universal-wish for some biographical particulars relating to $\mathrm{H}$. W. INerbert, we may commence by remarking that he was no curling-tongs count, nor runaway banker's clerk, but precisely what he always represented himself to be-an English gentleman, descended fiom and connected with some of the oldest and most aristocratic families in Great Britain and Ireland.

The Herberts (or Fitz-Herberts, as they are frequently called in England) are undoubtedly of ancient origin and high rank. The name of Fitz-Herbert, signifying Son-ofHerbert, came into vogue in consequence of the long interval between their early progenitor of importance, who was lord-chamberlain to King Henry I. from about 1120 till 1135, and the creation of William Herbert as Earl of Pembroke by Edward IV. in 1468.

Chamberlains were of some importance in England about those days, especially when they acted as officier $d u$ bouche, or moutl-provider (chief butler), for their royal masters. This office was always considered a safe position for an ambitious man. Henry I. was killed by a surfeit after eating too many lampreys-a kind of fish he was very fond of - at Lyons, in Normandy. Edward IV. generally overcame his surfeits; but, when he made prisoner of the Duke of Clarence, one of his brothers, who had joined in a rebellion against him under the Earl of Warwick, he ordered the duke to be drowned in a butt of Malmsey wine, and the sentence was duly executed by the king's chief butler. These little facts are only mentioned here in order to show that the family of Herberts would be likely to copy or inherit all the peculiar "notions" of monarchy since the days of the Norman kings; and, wherein they have not, we must give their heads and hearts credit for the difference.

The English people have gradually made their mon- 
archs understand the necessity and convenience of good behavior. Henry I. was the third of the four Norman kings. Then came fourteen of the Plantagenet family. Edward IV. was the twelfth among them. Then came five of the house of Tudor. Then followed six of the Stuart line. After these came five of the Brunswick line; and, finally, Queen Victoria. Now, as Henry I. (like his brother, William Rufus) was a son of Williain the Conqueror, the Herberts may be said to have seeu and survived nearly all the important changes in English society. There are but two other families more ancient in the provision of good things for the royal tables. These are the Botelers and the Dalbiacs, who "came in with the Conqueror."

- While attempting to judge of Herbert's character, all these antecedents of his family should be considered, as of course they (unconscionsly to him) helped to form in his mind those notions of classification and exclusiveness which seem so absurd and inexplicable to persons not acquainted with their historical origin and ancestral or legal importance. Herbert would be pleasant among gentlemen whom he knew to be such, according to his ideas; he would also be quite affable and jolly among his jockey acquaintances; but, as soon as he came near what are sometimes called "gentlemen-jocks," he seemed to try how ugly and wilful he could behave. Such was one of his "notions." He thus caused himself to be much misunderstood, and sometimes seemed to revel in the misunderstanding. He wronged himself, however, more than anybody else, for strangers cared not a snap about his notions, while those who knew him also knew that his heart was full of universal sympathy, and the sympathyseeking cast of his mind was admirably well qualified for adapting the most matured maxims of art to the fresh feelings and candid expressions of a free and independent 
people, as all his writings most conclusively show. How frequently do the most worthy individuals and greatest nations misunderstand each other's manners and customs!

The first Earl of Pembroke, already mentioned, was taken prisoner by the Lancasterian party, and belieaded by them in about a year after he obtained his earldom. His wife was Anne Devereaux, sister of Lord Ferrers of Chantley. She had a large family, but William Herbert's successors becane extinct in the male line after two more generations. From William's brother, however, have descended the famous Herberts of Cherbury, and one of these became Earl Powis in 1746. This line also became extinct in a similar way, and passed with a daughter of Earl Powis into the family of the famous Lord Clive, where it yet remains.

We do not know whether there is, or need be, any "bar sinister" upon the subject in the heraldic insignii of the Herberts, but it so happened that the aforesaid William Herbert, first Earl of Pembroke, left a son by a Welsh lady who bore his name of Herbert, in Montgomeryshire. The son of that son married Anne Parr, sister of Catharine Parr, the sixth and last wife of Henry VIII. This renewed the influence of the Herberts at court; and, after "Old Harry" was dead, in the year 1551, during the reign of Edward VI., the grandson of the first earl received the title of Earl of Pembroke by a new creation, joined with that of Earl of Montgomery, inherited on the maternal side. This title is now held by Robert Herbert, a descendant of the eighth generation, but reckons by fraternal mutations of the line as the twelfth Earl of Pembroke and the ninth Earl of Montgomery. Sidney Herbert, late Secretary of War in the British cabinet, is a brother to this personage.

Among the younger sons of Thomas Herbert, the 
eighth Earl of Pembroke, was General William Herbert, who distinguished himself greatly in the pubiic service, and also had the good fortune to marry Eliza Wyndham, distinguished as the great-grand-daughter of the Duke of Somerset and of Elizabeth Percy, who was a sister of the last Earl of Northumberland, of the old continental line of Joscelyn of Louvain. General William Herbert was, therefore, on these accounts, raised to the peerage, with the title of Earl of Carnarvon, in 1793.

The third son of this first Earl of Carnarvon was the Hon. and Rev. William Herbert, subsequently Dean of Manchester, and the father of the subject of these memoir's. Hence, it is clear that our own "Frank Forester," the modern author, was a descendant of the proud Percys, the irascible Joscelyns, and the ducal Somersets, commingled with the agricultural Herberts, as well as the literary and liberty-loving Sidneys. On the maternal side, besides the original Welsh blood of the Montgomery stock, he inherited an Irish influence of the very highest character, his mother being the Hon. Letitia Allyn, second daughter of Viscount Allyn of Kildare, one of the Irish representative peers, and a branch of the princely Leinster line. This estimable lady is now living in May Fair, London. Herbert's father, the Dean of Manchester, is best known to American readers as the author of "Attila." He was a profound scholar, and died in $184 \tau$.

Henry William Herbert was born in London on the 7th of April, 1807, a year which has been made famous by giving America her Longfellow and her Willis. Until the age of twelve, Master Henry was taken charge of by private tutors in his father's house, which, in those days especially, was a general resort for parliamentary wits and distinguished scholars. On entering his teens, Henry was sent to Dr. Hooker's academy at Brighton, on the Sussex coast. In April, 1820, commencing his four 
teenth year, he was entered at Eton, where his happy powers of analysis, or of synthesis, astonished all the professors. He made such remarkable progress that in 182.5 his father sent him to Cains College, Cambridge, and in the class of 1829-'30 he graduated thence.

While at Cambridge the society of the yonthful Herbert was eagerly sought after by more wealthy yourg commoners; and, as he was equally anxious to associate with them, he gradually formed some very expensive liabits. In books and in clothing, boating, racing, tandem drives, etc., he scattered money extravagantly; but there are always very kind old gentlemen, around colleges especially, who know a yonng man's pedigree and connections as well, if not better, than he does himself, and who have a particular regard for lending money to young gentlemen with large expectations themselves or parents able to pay np all forfeits. One of the best things Her. bert did while at Cambridge was to join a troop of Cambridgeshire Yeomanry Cavalry, a full squadron of which was occasionally "camped ont" on the rontes between Cambridge and Huntingdon, Peterborough, Lynn, Norwich, and sometimes as far north as Boston in Lincolnshire, as the different connties might invite each other's nembers, generally freeholders of the county, but always willing to receive recruits from among the collegians. By the knowledge of equestrian and field movements thus acquired, Herbert was subseqnently enabled to give us those fine descriptions of Roman battles, sieges, and campaigns (by the way, the historian Gibbon has made use of a similar advantage in early education among his works), which Herbert's delighted readers find in "The Captains of the Old World," or in "The Roman Republic," and which he intended to have continued. Much of the supposed hauteur of Herbert's manner arose from the fact that his mind was so freqnently "pre-occupied"

vot. $\mathrm{r}$. 
-as the French would say-with some other scene, in other lands, and among other languages, so that his return to present realities, and the use of vernacular English, required a mental effort which might easily be mistaken for lack of courtesy. There need be no doubt of this, for in his writings the magnetic chord of attraction is never interrupted between him and his readers, or between them and him. Nor does he make any parade of learned lore, either by allusion or quotation, except as they would suggest themselves to those scholars who can revel in similar flights of classic exploration and poetic adaptation. And yet, of all the writers ever gifted to charm all classes, we know of no one who has more uniformly kept in view the old maxim that-verbum dulce multiplicat amicos, etc. - sweet language will multiply friends, and a fair-speaking tongue will multiply kind greetings.

These considerations and circumstances remind us of the often mentioned difference implied by the exhortation-"Do as I preach, no matter what I may do." While at college, Herbert had so rapidly acquired a restless and reckless way of living, that his parents could exercise little or no control over him. He plunged deeper and deeper into debt after coming of age; and, on being "whitewashed" for the third time by the insolvency process, the usual sentence of outlawry for debt was published. Herbert then voluntarily went to Brussels, and afterwards to Paris; but neither the Continent, nor Europe itself, were large enough for his peculiar ideas, and "no pent-up Utica" could satisfy him; nothing short of "a boundless continent," like that of America, seemed wortlyy of his notice.

Herbert landed in this country about November, 1831, and the few hundred pounds he brought with him having been soon expended, he was compelled to turn his attention to business. He readily obtained an engagement as 
a teacher of Greek in the Rev. R. Townsend Huddart's classical and fushionable sclool, which at that time was in Beaver street, near Broadway. The duties of his station, and the select company he met with, were too much like those at his father's house at lome. Ierbert was, like Hazlitt, "an untamable lover of liberty," and he griadually began to write for the press, in a solt of annnynoms manner, but with no objection to the pecuniary results. Making the acquaintance of the editor" of the "Spirit of the Times," Col. Wm. T. Porter", the "tall son of" York," Herbert's contributions were gladly received. He then "did up the reviews" for the "Courier" and Enquirer," and soon made his mark as a keen and trenchant reviewer. Notwithstanding a discovery of these facts, it is due to the memory of the deceased to state that he retained the most lonorable confidence, while giving perfect satifaction, at Mr. Huddart's school for eight years.

In 1834, Herbert's first historical novel, "The Brothers, a Tale of the Fronde," was published by the IIarpers, and was very favorably received by the public. Such a writer certainly was an acquisition in those days, and the American mind readily acknowledged the author's claims to distinction. For some reasons we de not understand, and have no wish to interfere with, this work has been allowed to go out of print, although it is said that the pages are stereotyped, and the plates are in possession of Messrs. Harper, who refuse to allow any further use to be made of them. IIerbert was for a long time known to the public only by the title of "author of The Brothers," etc., but he never offered the Harpers any more of his MSS. A member of that enterprising firm is said to have been "hit off" in the "Warwick Woodlands."

From 1833 to 1836, Herbert was, more or less, connected with the "American Monthly Magazine," sometimes writing all the editorial matter, having succeeded 
Dr. A. D. Patterson, and joined Charles F. Hoffman in its editorial management.

In 1837, Herbert's reputation as a writer of historical novels seemed fully confirmed by the appearance of "Cromwell," which was even more favorably received by the American public than "The Brothers."

In 1838, Herbert became mixed up in a dispute leading to a proposed duel, which would undoubtedly have taken place but for a severe snow-storm, which prevented the parties from meeting in Canada as intended. The second of his antagonist, having subsequently reproached Herbert with cowardice at Washington Hall, in New York, the latter fired twice at his accuser, but the balls went into the door of the room as the other gentleman went out. This affair furnished much gossip for the small daily papers then coming into notice.

Washington Hall was on the Reade street corner of what is now known as Stewart's marble palace in Broad way. This hotel was the general head-quarters of all the "men about town," and the "Bucks of Washington Hall" was a title commonly given to the frequenters of its barroom. All the "odd fish" and "strange geniuses" were sure to go there, by a sort of tacit understanding, as soon as they arrived in New York. The hotel became particularly famous after it had been visited by Madame Mali. bran, and here it was that Mr. Gilfert, then proprietor of the Bowery Theatre, offered the gifted songstress the articles of an engagement, with blanks left for herself to insert such terms of payment as she might think proper. The arrival, in 1831, of such an "invincible" as Herbert threw "the whole crowd" into ecstasies. His cavalier boots, with King Charles spurs, were voted "just the cheese." His moustaches, such articles being rarely seen in Broadway during those days, attracted many a fair one's favorable glance from the opposite or fashionable side of the way. 
We do not mean to imply that Herbert was an inmate at Washington Hall, althongh, like hundreds of others, he visited the house occasionally. He was boarding at the Carlton House, whither he had gone in 1836, because his connection with the "Courier and Enquirer" and other papers, all published down town, had become so intimate as to engross a large portion of his time. James $O$. Sargent was in those days one of the leading editors of the "Courier," and a strong team-from Matthew I. Davis around to Charles A. Burdett-were engaged to fill the various departmental duties. As a reviewer and an occasional contributor of poetry, Herbert's name and presence became familiar in literary, artistic, and musical circles. As a natural consequence, his handsome person and fascinating manners caused the society of such a man to be inuch courted by the ladies, but his thoughts were too much occupied by his writings or by "the jolly dogs of the clubs" to seriously entertain the idea of marriage.

In this state of afficirs, Herbert was requested, one day in 1839 , to accompany one of his literary friends, $\mathrm{Mr}$. Joseph A. Scoville, on a wedding tour to Bangor, in Maine. Mr. Scoville was at that time in wealthy and promising circumstances. He was about to marry a Miss Barker, danghter of the then Mayor of Bangor. Herbert found that Scoville had so much set his mind upon having him as groomsman at the wedding that at last he consented to accompany the expectant bridegroom. The inconvenience of leaving business in New York would be compensated by a round trip of a thousand miles, and the pleasure of witnessing a joyful occasion.

After arriving at Bangor, there was, for some unaccountable reason, a slight delay. In the mean time, the astounding discovery was made that the intended bride was quite willing for the ceremonies of sacrifice at the bymenial altar to proceed, but it was with Henry William 
Horbert only for her husband; and thus the aforesaid Joseph A. Scoville found himself in a peculiarly perplexing predicament, and his mind has, we believe, never fully recovered from this distressing shock to its original sensibilities. These circumstances are a subject of gossip down to the present day in Bangor. This is, undisputably, a free country; our Puritan brothers in the East have peculiar ideas of European nobility; and the sway of female power is not only absolute but unquestionable in American society. The real motives of action in such cases are necessarily of a private nature, and it is not likely that they ever can be properly understood by outside lookers-on. We have here stated such facts as are known to have occurred, and they go to show that $\mathrm{H}$. W. Herbert was not the only odd character in his day and generation. As "Death loves a shining mark," so does "the reptile spirit of calumny."

History teaches that royal marriages, when conducted by proxy, sometimes lead to dangerous perils from the despotism of love. The ambassador is frequently thought more of than the prince who sent him. But Herbert was not the man to play the part of Dandini to any other man's Prince Fclix-Cinderella or no Cinderella. Herbert's principal was present.

The general consistency of Herbert's spirit-life may be seen in the fact that a happy marriage made him more useful and more admirable in society. Domestic disquiet being a fatal bar to all sublimity of attainment, no manhowever great he may be in the way of genius or of industry-can possibly prosper under such despotic and obtrusive misery. But, with a happy home, all the ordinary troubles of life are deprived of any serious influence, and the man has some chance for shining forth in lis true character. So it was with Herbert. In 1840, the year his son was born, Herbert extended his literary and poet- 
ical contributions to the press more freely than ever. It. was at this interesting period when the nane of "Frank Forester" becaine created firom Herbert's Jove-like brain, and the world has consented to receive

\section{"FRANK FORESTER"}

with all the honors, regardless of title or nation, heraldic derices or peerage looks, but simply for that love of Nature which makes "all mankind akin." The name of "Frank Forester" soon became famous by carrying on a very spirited controversy in the "American Turt Register" with the able articles furnished by "Cypress, Jr." "Our Frank" was joyfully received among the great family of public favorites. His "Ringwood the Rover" and "Warwick Woodlands," caused a general desire to have "a few more of the same sort." While thus engaged in producing some of the finest novels in his day, he found time to contribute many a good fugitive article to the "Knickerbocker Magazine," "Graham's Magazine," and several other periodicals. There was scarely an issue of the last named magazine without one, two, and sometimes three, articles from Herbert's ready pen; and these were generally thrown off by him without much thought or finish, as merely mental pastime among his other more permanent literary labors.

One of the articles Herbert furnished to Graham in 1841, was "The Roman Bride," a beautiful story, in which the general character of Attila the Hun, as portrayed by Herbert's father in his famous poem of "Attila," is well exemplitied by the incidents attending the interruption of the bride's marriage with Aurelius, and the dreadful combat between the sturdy barbarians of the Hun and the gallant champions of Roman virtue. The subject is renowned for its artistic beauties, and Herbert's treatment 
of it is a fine specimen of his doubly-gifted power of description and condensation.

Another of the articles sent to Graham in 1841, was "The Marriage of Achilles," which attracted general attention, for it showed the immense wealth of classic lore in the author's mind, and his ability to concentrate and reweave the charming fruits of previous ages of study into the small scope of a magazine article. It astonished some of our oldest and best-read collegians with its abundance of historical detail, and it delighted the most superficial readers with its easily intelligible gorgeousness of description, partaking of both the voluptuous and heroic. The article read as if the old spirit of Grecian mythology had taken up a new abode among the brightness of the American continent, to keep alive our love of the beantiful, while showing the ancient sword of military warfare crowned with a wreath of orange-blossoms and myrtle leaves, surrounded by a halo of poetic glory, "lambent and imitative of the lights that stud the empyrean."

However, our purpose at present requires us to pass on without stopping to indulge in a consideration of Herbert's writings, except so far as they give some outline of his life and character. Suffice it to say, that public favor induced him to gradually make his choice of subjects more familiar; for, with all his funlts, he was true to his great patron-the American people. His "Marmaduke Wyvil; or, the Maid's Revenge," published in 1843, was uncommonly well received, but he wrote more and more sporting matter as he found "Frank Forester" was a more potent name than even that of H. W. Herbert. His connection with the "Spirit of the Times," and its then editor, Wm. T. Porter, was Herbert's most magnetic; link of communication with popular favor, and many a "spicy article" has been concocted among the frequenters near the "old Spirit" office, when it was in Barclay 
street under the American IIotel, on the corner of Broadway, in the good old days of Col. Cozzens. This kind of influence subsequently brought forth those treatises on sporting matters and natural history which have now become standard works in our national literature.

$\mathrm{Mr}$ : and Mrs. Herbert, shortly after marriage removed from the Carlton IIouse, in New York, to the Park House in Newark, N. J. In 1846, Mrs. Herbert died while at the latter place. Their son had been sent to England, where he found great favor with all his father's relatives, and his education had been already undertaken by them. A proposition was made for the purchase of a house and hoinestead for the youthful Herbert, which, howerer, should be inalienable for any other purpose, except it might be as a residense for II. W. IIerbert (held by a deed of trust) until his son became of age. Herbert, liaving long liked " the Cedars," a little shooting-box between Newark and Belleville, suggested its adoption, and took up his entire residence there shortly after Mrs. Herbert's death. It is a romantic little spot, only an acre of ground, and the cottage is built in the Mary 'Tudor style, so situated as to be enbowered in foliage.

Here the mind of "Frank Forester" gave forth "My Shooting Box," "Dallads of the American Revolution," "The Field Sports of America," "The Deer Stalkers," "The Quorndon IIounds," "Fish and Fishing of Torth America," "Game in its Scasons," "The Young Sportsman's Manual," and, finally, his great work on "The Horse and Horsemanship of America." Among the unfinished works at the time of his death were, "Tricks and Traps of Horsedealers," "Hints to Horsekeepers," etc.

As H. W. Herbert he was equally busy, although, perhaps not yet so popularly known, by such works as "The Roman Traitor, a Romance founded on Cataline's Conspiracy," published in $18 \pm 8$. This was followed by 
"A Metrical Translation of the Prometheus and Agamemnon of Aschylus," "IIenry VIII. and his Six Wives," "The Cavaliers of England," "The Chevaliers of France," "The Knights of England, France, and Scotland," "The Captains of the Old World," "Persons and Pictures from the Histories of France and England," "The Captains of the Roman Republic," and "The Wager of Battle." But the greatest effort in this class of writing remains unfinished-a spirited translation from the "Iliad" of Homer; there is also a beautifully romantic account of "The Marys of History," the MS. being quite complete, as he left it, but of course additional characters might be selected.

Besides these acknowledged works, his contributions to newspapers and magazines are almost countless. In 1850 he gave much time to a paper called "The Sunday Era," and in 18.51 to another called "The Sachem," both published in New York. He also contributed many articles to what is now known as "Ballou's Pictorial," in Boston. Dr. Patterson's "Anglo-American," about 1839, had fledged his pen for newspapers.

We have more occasion to speak of Herbert as a writer than his private affairs as a man; but, in order to make this sketch as complete as possible, we must record the fact that he had some trifling dispute with a legal gentleman named Valentine, which resulted in a duel, and took place near IIerbert's residence at "the Cedars." After Herbert had been shot near one of his ankles, and Mr. Valentine lost a button from his waistband, the affair was amicably settled. By a sad coincidence with Herbert's subsequent fate, we may state that Mr. Valentine committed suicide shortly after this duel. The previous duel in which Herbert's name was concerned owed most of its notoriety to the fact that it almost inmediately iollowed the fatal renenntre between Barton and Graham, at 
Hoboken. The duel with Mr. Valentine attracted but little notice, and we should hardly mention it here except for the sake of impartiality.

Our duty now leads us to a much more delicate affair, in which we hope to be correct without intrusion. In February, 1858, the newspapers of Newark, N. J., and New York, announced the marriage of Henry William Herbert with Adela R. Budlong, as having taken place on the 16 th of that month. They were married by the Rev. John Shackleford, at the Episcopalian Honse of Prayer, in Newark. This announcement caused considerable gossip, but that soon subsided. Herbert was in ecstasies with his new choice, and sad only when she was absent. In a few weeks, among the callers upon the newly married lady was a person who professed to know much of Herbert's affairs, and also to have such a great regard for the new Mrs. Herbert that she could not take her leare without giving her a large amount of very spicy information, taking great care, however, to exact a promise that the name of the informant should not be revealed.

From that moment, peace fled the happy abode at "the Cedars." All poor Herbert's plans of reforination and future improvement were upset. Mrs. Herbert is said to have left the house while he was absent in New York, whither he had gone to engage rooms at the Stevens House, thinking that more lively company and less slanderons callers would be more agreeable for Mrs. IIerbert. His clear use of reason never fully rallied after he discovered her departure; and, when he received a letter stating that she would not visit him again, he spoke frequently of committing suicide, on the same day of the month in which he was married. His friends became alarmed, and watched his movements; but, about two o'clock in the morning of the 17th of May, 1858, the un- 
fortunate gentleman shot himself while in his room at the Stevens House, after withdrawing for a moment or two from the presence of $\mathrm{Mr}$. Philip Hone Anthon, who had been in his company all the previous day and evening. The result was fatal. Two letters were found upon Herbert's table. One was addressed to "the coroner," and the other to "the Press of the United States." They read as follows:-

Mondat, May 16, 1858 (three months since the happiest day of my life.)

To avoid all trouble, and simplify your duty, I have to state that I have taken my own life by a pistol shot, no one being privy to my doing it, or to my design.

My reason for this act consists in no remorse for what I have done, or left undone; from no pecuniary pressure, from no inability, or fear of inability to support myself, from no weak fear of public opinion, least of all of New York, which I do now, as I always have done, utterly disregard and despise ; from no embarrassment arising from any indebtedness.

I have abundance of employment, and the prospect of much more -had the people of Newark, whom I forgive, from the bottom of my heart, suffered me to live honorably and happily in my humble home, and to amend $\mathrm{my}$ life where it was in error, in a new sphere, which I was honestly prepared to do, I might have paid off all my debts, and lived many years among you, an honest, useful, and happy man. My debts will be paid from my assets to the last dollar.

It was not, however, so to be. My blood, and the guilt of it, is upon those women and men who first sowed suspicion, distrust and dissension between myself and the sweetest creature God ever gave, and man took away from an unhappy sinner. My own unhappy temper did the rest.

The reason for this act, then, is simple. My life, long, sad, solitary and weary, and without an object beyond labor to earn a living for the day, has become utterly hopeless, hateful, and unendurable. A hope had been kindled in my heart again; my home had got a light in it brighter than sunsline; my life had a purpose; I loved her unutterably; I was immeasurably happy-all this has been dashed down-all is lost forever. Home-lope-sunshine, she-let life go likewise, since, henceforth, it is only another word for torture. 
I would not deny falsely one fault of which I am conscious, especially at this last moment-I would not deny that I erred towards her whom this day shows that I loved more than life. I did err, but it was hastily. In any act or rash word, never, so may God deal with me, in thought or intimation. I never had one word with her about money matters, nor cared-scarcely knew whether she had or had not money. I never laid a hand or finger on her in wrath in my life. What I said or did wrongly, I repented on the instant-I hare endeavored to atone for it ever since--I die for it this day. I think, I hope I deserve pity more than blame, but I know that I shall not find it, least of all in Newark.

I can say truly, with my last breath, I never wronged man or woman in my life by premeditation, or failed to ask pardon, or to make atonement when I could do so. I never bore malice in my life. I repent of all iny faults and sins, and have endearored to amend them.

I die in perfect peace and charity with all men. I ask forgireness of all those against whom I have sinned. I forgive all those who have sinned against me, even the woman whocalled at my own house, and set my wife's thoughts first against me-in proof of it I am sure I know her, yet do not name her name. I beg God to forgive me, as I forgive all my enemies. I die in perfect faith and trust in my Redeemer, and believe in him I shall have eternal life.

\section{Hexrí William Herbert.}

\section{To the Press of the United States:}

Before going to my account, I would say a few words to the Press of $\Lambda$ merica, and to its conductors, as to men among whom I have, for many years, been more or less associated.

I have my faults. my failings : I have done my share of evil, in my life, as all men have done; perhaps I have done my share of good. likewise.

Of my private history few men know any thing-fewer still know much-no one knows the whole. It cannot concern the public to know any thing. As a writer let me be judged-as a man let my God judge me.

I implore not praise, nor a favorable construction-I implore sIlexce. For what $I$ hare to account with God, let me account with God, and not with man; who may uncertainly perceive and distin- 
guish facts, but certainly cannot perceive causes or divine motives and intentions.

I do not even ask charity; I only implore silence. Let the good that I have done, if any. be interred with my bones; let the evil also. For the evil. I can say positively. is such as can do no evil after me. I have taught, I have inculcateu, I have put forth nothing which I did not believe to be good and true. In all my life I have written no line of which I an ashamed-no word which I desire to blot.

I have done many things wrongly, many things of which I am ashamed many things of which I have sincerely repentud. many things, under the pressure of poverty and necessity, to which I an not accustomed by my education, which, I hoje, I should not do again under any temptation.

I am very sorry. I have been weak at times, and have fallenwho has not done so?

Fur justice sake, for charity's sake, for God's sake, lct me rest. I bear an honorable name; I have striven hard, in great trial, in great temptition, in a forcign country, in a false position, among nen who did not, perhaps coull not, sympathize with we, to keep it honorable. As you would have your own names honored, and your sons preserve them to you, I charge you, do not dis'ınor mine.

Few will niss me when I am gone; probahly none lament meso be it! Only, I implore you, do not misrepresent and malign me.

Having said this, I have sail nearly all-one word more only-if, as I presume will be the case, my earnest and hopeful appeal for repose be disregarded-if the vultures of the Press pounce on my cold remains, to tear through them the heartstrings of $\mathrm{my}$ living relatives - to blizon forth all my misdeeds in unhlushing colors to the sunlet none of iny friends-if I have a friend-stand forth to lefend me. Defence only provokes bitterer attacks, and gives a keener tooth to scandal.

I die forciving every man who has wronged me, asking forgiveness of every man whom I have wronged. I have atoned so far as I know, or can atone, for every wrong I have ever done.

I leave the means, I belieie, if they be carefully managed, to pay every thing that I owe, amil perhaps to leave a small surplus. I never shrank, while I was alive, from meeting the consequences of my deeds, face $t^{\prime}$ ) face. I never said a word to a man's back which I would not or did not say to his face.

Remember now, all you that would assail me, that my back is turned, forever-that henceforth, forever, I can disprove no slander 
that is spoken of me; that with me no witness can be ever more confronted; that from no accusation, how false soever, can I prove myself not guilty. Of all cowardice, the inost base and cruel is to strike the dead, who can make no defence or answer.

I ask no praise-do not praise me-probably I deserve none.

I deserve reproach, doubtless, for I am mortal, and have sinned. Say so, then, of me, if you say any thing, and let my sins go with $m y$ mortality to llis judgment who can tell not only when and where, but why they were committed, and how far they have palliation, how far they deserve pardon.

Remember, also, when you judge me, that of all lives mine has been, almost, the most unhappy. No counsellor, no friend, no country, have been mine for six and twenty weary years. Every lope has broken down under ny foot as soon as it has touched it. Every spark of happiness has been quenched as soon as it has been kindled. If I have sinned much, and sorrowed much, I have also loved much-more, perhaps, than I have either sinned or sorrowed. It is the last drop that overflows the golden bowl, the last tension that breaks the silver cords. My last hope is gone-my last love and my life go together and so good night to

May 16, 1858.

HeNry Herbert.

At the first announcement of Herbert's death, his friends naturally viewed his last injunction of "silence" in a positive and forbidding sense, and the following hasty, but evidently heartfelt, remarks were immediately written by the gifted and renowned "Acorn," whose friendship IIerbert had had the honor of enjoying. Surely any very bad man could not have caused so spontaneous an expression of refined and honorable feelings from his literary compeers and associates, especially from one whose acquaintance had existed for a quarter of a century :-

\section{HENRY WILLIA II HERBERT.}

"The evil that men do lives after them;

The good is oft interred with their bones."

The friends of H. W. Herbert, in this city, were appalled at the announcement of his death, a few days since. The sad intelligence 


\section{xxxiv}

fell upon the heart of the writer, who has known him for over a quarter of a century, like a withering mildew, and, were it not for the dying injunction of poor Herbert, that his friends should remain silent, my feeble pen, directed by the best energies of my brain, should reveal the deep sympathies of my heart for one whose life, although somewhat wayward, was nevertheless marked by many virtues and bright deeds.

Henry William Herbert, the brilliant genius and rare scholar, is in his grave!

\section{"After life's fitful fever he sleeps well."}

For charity's sake, let not the sanctity of that grave be desecrated by heartless or unfeeling scribblers, simply to feed or gratify the appetites or morbid tastes of those whose wicked and malignant slanders were mainly instrumental in wrecking so bright a mind! After frenzying that once noble intellect, and sending its owner unbidden into the presence of his Maker, may we not hope, for humanity's sake, that the portals of the grave may be a barrier against the poisonous tongue of the earth's greatest pestilence-the slanderer!

For the sake of those whose veins bear kindred blood, and whose hearts and spirits are now bowed down to the dust, forbear, I implore you, and no longer aim your poisoned and malignant arrows of revenge at the dead, through the already lacerated spirits of the living! But let the f.ults and the weaknesses of him, whose earthly career met so melancholy and fearful an end, slumber in silence with his ashes in the tomb! For mercy's sake, let his kind acts and charitable deeds, only, rest in the minds of his fellow-men, for many such acts and deeds are known to the writer, which will assuredly be placed to the credit of him who has gone to his account, at the final judginent day. Were it not for violating the last request of this extraordinary man, I would reveal many bright and manly characteristics; but the observance of a request, made almost with his expiring breath, forbids, and tells me to drop a curtain over his grave, on which to write in letters of gold-Silence! Peace to the ashes of Henry Williay HERBERT!

AOORN.

Bostox, May 22, 1858.

It is of such a man as Herbert we now proceed to speak Among the private letters left to Mr. Anthon. 
whom he appointed as his executor, was the following, addressed to Mr. I'Anson, a right trusty and well-beloved neighbor, in Newark:-

My Dear Mrles I'Anson: The time has come, and I call upon you with the last words of a dying countryman to come and perform your promise. My last friend, do not fail me.

When you receive this I shall be lying dead in the cemetery. I could not be easy in New York, and I must not be buried in the Potter's Field or by charity.

Have me dressed in the clothes which I have put in the carpet bag, with the little packet I have sewn to the shirt upon my heart, and the pin-cushion with "IIerbert" pricked upon it, under my head -a plain oaken coffin, with this inscription only: "Henry William Herbert-aged 51."

Let me be buried in your lot; send the coffin down by the steamer; no funeral and no pomp. I send a note to Mr. Shackleford; he will perform the service.

I enclose a draft for ten pounds sterling on my sister, which will pay all expenses; I have written to her. Come the moment you receive this, or you will be too late, and they will thrust me into some hole away from humanity. She has refused all reconciliation absolutely and forever, but she is not to blame, and it is my last request that no friend of mine will blame her or defend me, except to say what I solemnly swear with my dying breath, that I did not marry her for moneythat I did not know when I married her, and do not know now, whether she has any money or how much-that I never had a word or dispute with her about money, and never said one unkind word until that Monday, when I threatened my life if she would not tell me who had accused me to her falsely.

God forgive and God bless her! I forgive all men who have wronged me, and ask forgiveness of all whom I have wronged. Every shilling I owe in America will be paid from the lease of the house, and the books I leave behind me, ready to be published.

Give my best parting love to all my friends, think of me sometimes as a most miserable man, yet your true friend,

Henry Wy. Herbert, Stevens House.

May 15, 1858.

VOL. I. 
I wish to have a very small, very plain headstone, of Little Falls, or Belleville stone, with this inscription:

\section{HENRY WILLIAM IIERBERT, \\ of \\ ENGLAND, \\ Aged 51 years. \\ Infelicissimus.}

Will you take care of Vixen? She has been my only comfort. she has never left me for one moment. I am sure she knows I am wretched. God bless you and your wife!

Here we may perceive how bravely the fine spirit of "Frank Forester" continues to shine out, even from the shattered mind of H. W. Herbert. He cannot bear the thought of being buried "away from hmmanity." No, indeed. Then, with regard to poor little Vixen, (a blackand-tan farorite among his dogs,) he is quite sure that "sire knows I am wretched." Another of the private letter's, directed to one of Herber't's most esteemed friends, reads as follows, and shows the chivalry of a spirit which could not bear to be suspected :-

"MY DEAR - What is done is done and cannot be undone. I know you will blame and probably despise me; but the strength of one man is the weakness of another, and I could not endure the agony I have been suffering.

If ever I have vexed, wronged, or offentled you, I sincerely and humbly beg your pardon.

As the last request of a dying man, I entreat you, on account of this, not to throw up my affairs, but to endeavor to settle them fully. I am satisfied that with the rent of the Cedars and my own goods, \&c., there will be enough to pay every thing that I owe on earth.

I have the manuscript of three books all ready for the pre $s$, which ought to produce at least $\$ 1000$, and I think that in view of this act of mine, good or bad, they would sell even now-

I assure you that I have received a letter from my leloved wife. 
which exonerates her of all blame, except for over-credulousness, sensitiveness, and a weak fear of me, who would have died a hund:ed times rather than harm her. I entreat you as my last request, not only not to speak, but not to think unkindly of her.

Never seek to defend my memory at any suit to her discreditonly you can assert, for I consulted you lefore we were married, and you know it, that I never cared, much lcss knew, or inquired any thing about, her property or troubled her about it.

liememher, always, that I love her beyond any thing on earth. I would even ask you, if it ever be in your power, to protect and assist her as my beloved widow.

Fare you well, old friend; think sometimes of old days, and your friend,

Henry Wa. Herbert.

The general directions for the funeral (which had an attendance of the highest respectability) were faithtully obeyed. The corpse was taken to "the Cedars;" and here the picture of desolation, caused by the sudden stopprage of all "Frank Forester"s" little plans of confort and usefulness, seemed sad indeed. IIere it was that he had hoped to entwine the jessamine of aniability and the linden of conjugal affection annong the cedars of glory which tower to the skies. But now, under a clouded aberration of his usual life-hearty intellect, our own well-beloved "Frank Forester" had thrown himself into the arms of Death, as if irresistibly impelled by the chastening rod of a sorrow which was more than he could endure:-

"Dear, beantenns Death! thon jewel of the just,

Shining nowhere but in the dark!

What mysteries do lie beyond thy dust,

Could inan out-look the mark!"

As the deceased gentleman was himself the son of a minister in the Episcopal communion, and well knew that the rubrics of the "Book of Common Prayer" forbid any 
minister under that discipline to perform funeral services at the grave of persons who may have committed suicide, the proceedings on the present occasion were somewhat novel. Rev. Mr. Shackleford, the clergyman officiating at the marriage of Herbert with his last wife, was present; and, after the company had taken a last look at the corpse, the reverend gentleman alluded to the above circumstances, and regretted that his obligations of duty forbade him to appear in any other capacity than as a friend of the deceased, whose faults (he felt sure) were all on the surface of his character, but whose virtues were more numerous than could be generally known. All true friends of the dear, departed Herbert, would therefore follow the remains slowly and silently to the grave, and see them slowly and silently interred, with only those expressions which might be suggested or occur from a mute sorrow. Expressing a hope that the God above, who alone can judge of sincerity of heart, would have mercy upon the soul of the deceased, and of all those now present, the reverend gentleman concluded his remarks, and a silent sorrow pervaded the entire assemblage.

The procession passed through the gate by which the grounds of Mount Pleasant Cemetery, adjoining " the Cedars," are entered. It was at this spot where Herbert and his wife shared that kiss which became a parting kiss, and where, according to the letter left for Mr. I'Anson, Herbert expected to die. Some green twigs from the neighboring trees were sadly but hopefully thrown upon the coffin, and the assemblage departed.

"Youth flies, life decays, even hope is o'ercast;

No more with love's former devotion we sue:

He spreads his young wing, he retires with the blast;

The shroud of affection is love's last adieu!" 
Probably no man ever lived who was more likely to realize the poetical measure of misery indicated by such a case, as we find it expressed in Anacreontic lyrics, and familiarized in Byronian lines than Herbert:-

"Oh! mark you yon pair: in the sunshine of youth

Love twined round their childhood his flowers as they grew; They flourish awhile in the season of truth,

Till chill'd by the winter of love's last adieu!"

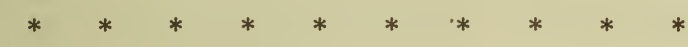

"In vain with endearments we soothe the sad heart,

In vain do we vow for an age to be true;

The chance of an hour may command us to part,

Or death disunite us in love's last adieu!"

The circumstances attending Herbert's second marriage were much more romantic than those of the first, but we prefer to leave these matters for the developments of time and legal investigation. We fecl free to say, however, that Herbert has been "more sinned against than sinning." As for his striking a woman, or caring about her money, that might have been possible-when sky-larks run a quarter-race or eagles play at skittles.

Notwithstanding Herbert's own estimation of the feelings entertained towards him in Newark, and around the neighborhood of his residence, there need be no doubt (and it is a matter of pride to observe the fact now) that he was mistaken on that matter, so far as regards the respectable portion of the population. It was a part of the great error which his mind labored under. The news of his death was received with expressions of general 
regret, as well as cansing the grief of those associates who might well say, in old Roman style,-

"Friends, I owe more tears

To this dead man than thou shalt see me pay."

Mr. Thos. T. Kinney, the talented editor of the "Newark Daily Advertiser," seems to have been a constant and particular friend of the lamented Herlert. The most authentic statements of Herbert's last troubles may be found in the columns of that admirable journal, and $\mathrm{Mr}$. Kinney now has in his possession the little black-and-tan terrier, Vixen, poor "Frank Forester's" true friend, who remained faithful to the last, winning from him the title of his "only comfort." Many persons connected with the New York book-trade reside in that part of New Jersey, and were, more or less, acquainted with Herbert, but we know of no one who has not acknowledged a pang of grief on learning the untimely end of "Frank Forester," the gay and rollicking preceptor of Young America in the "gentle science of woodcraft," that science which is always ancient and ever new to youthful hearts and emulative spirits.

The omission of certain ceremonies at the grave of poor Herbert may furnish some satisfaction to the vultures of vituperation. Herbert well knew this. His words to Rev. Mr. Shackleford were, "Do the best you can for me." But, that Herbert's friends were numerous and enthusiastic in the place of his residence, may be inferred from the fact that when Rev. Henry B. Sherman, Rector of Christ Church, Belleville, N. J., offered to second any judicious compromise which might be suggested to save Herbert's body from being consigned to the grave without some token of Christian burial, the reverend gentleman's kindness met with a prompt response 
as a kindness (for lis action was courteously dispensed with), by a large number of the most influential citizens of Newark and vicinity, as soon as they understood the circumstances of the case. A testimonial to Mrr. Sherman was subscribed for, and we append the document as a sufficient refutation of the absurd slander that Herbert lacked firiends in the place where he was best known. The signers are all fair "representative men," well qualified to speak for Newark:-

The subscribers, desirous of showing their regard for the Rev. Henry B. Sherman, of Belleville, and especially their admiration of his conduct at the funeral of the late Henry $W$. Herbert, in his wil. lingness to perform some Christian ceremony over the grave of the deceased, cheerfully contribute to the amount necessary to procure a suitable testimonial.

John Morrison,

Win. T. Mercer,

F. H. Dawes,

F. E. Berier,

E. A. Carman,

Geo. B. Halsted,

Alex. N. Dougherty, M. D.,

F. W. Ricord,

Thos. B. Peddie,

Thos. T. Kinney,

A. Bigelow,

J. P. Pennington,

Lewis C. Grover,

J. D. Orton,

Cornelius W. Tolles,

J. Callaway,

G. Grant, M. D.,

Bethuel L. Dodd, M. D.,

Silas Merchant,
Wm. S. Faitoute,

I. M. Andruss, Abram Coles, MI. D., James Ross,

R. B. Hathorn,

Cortlandt Parker,

O. H. IIalsted, Jr.,

H. B. Miller,

A. Sclialk,

H. Schalk,

C. T. Zeigler,

A. M. W. Ball,

T. Seaman,

Morris R. Hamilton,

N. N. Halsted,

J. A. Pennington,

Richmond Ward,

A. Jackson Drake, U. S. N.,

J. Southard.

A beautifully bound copy of Herbert's "Horse and Horsemanship of America," his most elaborated and com- 
plete work, one of the most splendid books produced by the arts of printing, engraving, and binding,-acknowledged to be the best work of the kind in the world, and the most successful publication of its class by subscription,-was presented to $\mathrm{Mr}$. Sherman as the most appropriate and acceptable gift they could select, and the presentation was accompanied by a spirited and suitable letter from Mr. F. W. Ricord, cliairman of the commitiee having the matter in charge. The Rev. Henry B. Sherman's letter of acknowledgment does him great honor; and the whole proceedings show that both national feeling and Christian sentiment were warmly enlisted on behalf of the unfortunate deceased, notwithstanding his many eccentricities. Let it not be said on either side of the Atlantic, for it is not true, that Americans ever failed to reward the talents of "Frank Forester."

What was Herbert is now "Frank Forester," for ever, in American literature. The latter was not exactly "the Persian rose" but "the flower that grew beside it," and now we can hardly tell which most attracts the admiration of the world.

There is a grand moral to be drawn from Herbert's untimely fate. It teaches us that if even he, out among the fields with his dog and gun, or cantering along the road with a free-breathing courser, or tickling the trout out of their native streams, even he-the all-conquering "Frank Forester"-must succumb to consuming cares and hopeless passions, how requisite it is for all of us to be on our guard against falling into a similar abnormal state, by patronizing a due share of field sports, or at least some stated relaxations from business by the aid of travel and agreeable society. To professional and literary men, especially, Herbert's case is full of warning, and their matrimonial partners would do well to learn that society ha; "rights" as well as individuals. A more conserva. 
tive tone of action seems needed by all classes, and the cultivation of suitable out-door sports for the people is a subject worthy of the wisdom of a second WAsungton.

Herbert had all the self-sustaining hardihood of a Dante with the fertile aptitude of a Brougham. But, look at the dreadful cost of such efforts. See the morbid irritability of Johnson, Pope, or Byron. See the tumbledown helplessness of Tom Moore, and even the carefully conservative Bob Southey, in their old days. Hark to the plaintive cries from Tasso's cell. Observe the fierce insanity of Collins or Swift. What should we say of Poe, or Lippard, or North? What should we say of those who are said to "die young" in the vain attempt at literary glory? Our own Tuckerman has judiciously observed that "God is not less worshipped by select intelligences, through fidelity to the natural laws, than by celebrating his glory in the triumphs of art." The sad case of Hugh Miller must be fresh in the minds of our reader's, as that of the great devotional geologist who lately shot himself in Scotland, while in his studio, surrounded by fame, easy circumstances, and the consolations of religion. And yet, so dreadful are the life-exhausting effects of severe study, that only the very thoughtless would dare to sit in judgment on its unfortunate victims.

To the credit of Herbert, "Our Own Frank Forester," we may say that his field sports did save him from dwindling down to a inisanthrope. Let us be thankful that he did not reach that deplorable degree of mental degradation. A lover of Nature cannot harbor a very bad heart. Hence we find that Herbert did not leave his ever-fatthful "Vixen" unprovided for"; and, so far from being any thing like a misanthrope, he begs and prays that he may not be buried "away from humanity."

That Herbert's intellectual powers had been by no means impaired, but were on an increase of ability, can 
be easily seen in his latest writings. Among these we may mention the beautiful story of "Omémees," which he commenced in "Porter's Spirit of the Times," when that admirable sporting paper was started by Messrs. Porter and Wilkes, in September, 1856. The opening paragraph of this interesting tale is one of the finest descriptions of the loveliness of a September morning, among American scenery, that ever was written in prose. The whole contribution reads as if its anthor was anxious to repay the fostering kindness of his old friend of "the Spirit;" and W. T. Porter's associate editor, George Wilkes, very properly called public attention to it, in their first number, as a "loud, ringing peal from the clarion of Frank Forester." And so it is, now ringing in our ears more sweetly sonornus than ever, inspiring renewed reverberations every year among those hearts which can enjoy the glories of our September landscapes.

Perhaps the day may not be far distant when the importance of "condition" will be familiarly understood to have quite as much influence upon mankind as upon the lower animals. If Herbert had had the timely benefit of good medical advice, or-what is much more rarely found -the wisdom of docility in obedience to its teachings, he might, in all probability, so far as human calculation could tell, have been spared for a longer and more useful life, cheering us with the continued creations of his charming pen.

Scarcely any class of men are so apt to "break down" as public writers. Critical and splenetic by acquired habits, if not by nature, engaged in a sedentary employment, and continnally forcing the activity of their cerebral region, all at once, when, perhaps, their most intimate friends may not think of the real canse, the balance of judgment-or", what amounts to the same in practice, "the blood and judgment are not well commingled"-is thus 
set aside. This misfortune may or may not assume a very decisive or sudden character in ontward appearance, any more than other forms of monomania need necessarily be violent in their demonstrations. But, it is at work, nevertheless, and interfering with the normal colierence of ideas, especially if any acrimony of the blood is allowed to remain long enough for the creation of norbid humors. In all the arrangements made by Herbert for his suicide, funeral, etc., the usual rigor of his intellect expresses itself in the remarkably precise and deliberate directions he so rapidly gave in writing. He is "all right," except on the "one idea" - and this wrong idea (without being, perhaps, perceptible to unpractised observers) was the result of a morbid condition-gradually superinducing an abnormal mentality-like the last efforts of an expiring flame, which finally destroys itself.

There need be no doubt that it Herbert's brain, plexus, arterial system, etc., had been restored to their usually harmonized degree of "condition," so noble and gifted a mind-instead of wrongfilly supposing itself to be in the right-would never have committed the sad error of judgment we now so deeply deplore. The peculiar phase of phrenitis he labored under appears to have been quite sufticient for gradually taking away his moral accountability. The lesson is sometimes taught to the most gifted minds-before they leave this sublunary sphere-that Heaven is our only Friend, our only Refuge, our only Saviour. Let us, therefore, fervently hope that human charity will leave poor Herbert's final error to the only Power capable of judging that and all his other failings.

These failings-or whatever they may be termed-are not mentioned here from any morbid desire to parade them in connection with so bright an example; for, be it remembered that, down to the last of Herbert's instructive life, the very manner of the unfortunate-most unfor- 
tunate-gentleman's death is one more additional proof of how much we all need greater regard for out-of-door sports, conversational hilarity, or heavenly aspirations, while less attention should be given to corroding cares, passionate impulses, or rash conclusions. We have merely endeavored to impartially describe that "Frank Forester" whose gentle, but proud spirit, scorned the vulgarity of carving his name upon the rising tree of American greatness in any manner that could possibly injure any other person, but has derived his principal pleasure while living - and his most glorious fame after death-from the fact that as soon as we take up one of his books, that noble spirit-sweetly responsive to our own-seems to take us also by the hand, leading us forth into forest wild or homestead beautiful, where we may willingly acknowledge the magic sway of the original and creative "Frank Forester" himself, while he guides our field sports, suggests our healthy pastimes, teaches us to tread lightly among those beautiful flowers which the poets well describe as "the scriptures of the earth," or imparts an additional tone of elegance to those charming family circles where eyes of light and forms of beauty come forth to grace the scene.

Much more-very much more-might be written by pens competent or worthy to discuss the memoirs of Henry William Herbert. Less we conld not have said, in ordinary justice. After all, while conscious of the comparative incompleteness of our effort, and we have said our say, or sung our lay, as best we may,

"The rest-let Sorrow say." 


\section{FIELD SPORTS}

OF THE

\section{UNITED STATES AND BRITISII PROVINCES.}

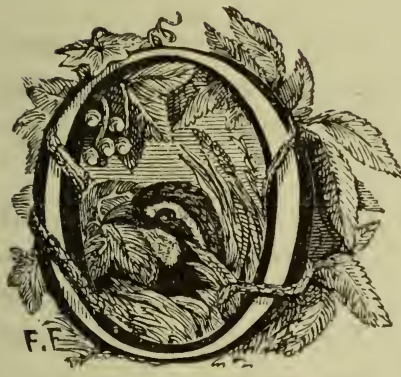

$\mathrm{N}$ the occasion of commencing, it is now several years ago, a series of papers in a leading monthly magazine, "On the Game of North Anerica, its nomenclature, habits, haunts, and seasons; with hints on the science of woodcraft"-I introduced the subject, by the following general remarks, and it appears to me that, inasmuch as they are not only still applicable, but have in effect become more and more evidently true, owing to the lapse of time since their publication, during which the evils complained of have increased tenfold, I cannot do better than repeat them, as entirely germane to the matter, and as aptly introductory to that which is to follow.

"There is, perhaps," I remarked, " no country in the world which presents, to the sportsman, so long a catalogue of the 
choicest game, whether of fur, fin, or feather, as the United States of North America ; there is none, probably, which counts more numerous, or more ardent, devotees; there is none, certainly, in which the wide-spread passion for the chase can be indulged, under so few restrictions, and at an expense so trifling.

"Yet all this, notwithstanding, it is to be regretted greatly that there is no country in which the nomenclature of these ferce natura, these roving denizens of wood, wold and water, is so confused and unscientific; none, in which their habits are so little known, and their seasons so little regarded; none, in which the gentle craft of Venerie is so often degraded into mere pot-hunting; and none, in which, as a natural consequence, the game that swarmed of yore in all the fields and forests, in all the lakes, rivers, bays, and creeks of its vast territory, are in such peril of becoming speedily extinct.

"That in a nation, every male inhabitant of which is, with but rare exceptions, a hunter, and ready with the gun almost beyond example, this should be the case, can be explained only by the fact that, as I have said before, little is known generally of the habits of game; and that the rarest and choicest species are slaughtered inconsiderately, not perhaps wantonly, at such times and in such manners, as are rapidly causing them to disappear and become extinct.

"That such is the case, can be proved in a few words, and Ly reference to a few examples. The most evident, perhaps, of these, is the absolute extinction of that noble bird, the HeathHen, or Pinnated Grouse, Tetrao Cupido, on Long Island, where, within the memory of our elder sportsmen, they might be taken in abundance at the proper season, but where not a solitary bird has been seen for years. In the pines on the southwestern shores of New Jersey, and in the oak-barrens of northeastern Pennsylvania, the same birds were also plentiful within a few years; but now they are already rarce aves; and, after a few more returns of the rapidly succeeding seasons, they will be sntirely unknown in their old-accustomed places."

The same thing is the case, in a yet greater degree, with re- 
gard to the Wild Turkey. It is not yet half a century since these birds, the noblest wild game of the Gallinaceous order, abounded on the slopes of the Warwick and Musconetcong Mountains; in the Shawangunks; and, in a word, throughout the whole length of the great chain, which connects the White Mountains of the north, with the Alleghanies proper. I have myself conversed with sportsmen, in the river counties of New York, who, in their boyhood, thought less of killing their halfdozen Wild Turkeys in the morning, than we should now-a-days of bagging as many Ruffed Grouse. At present, with the exception of a few stragglers which, I believe, still exist on the Connecticut, about the rocky steeps of Mount Torn and Mount Holyoake, and a single drove, which are reported to be seen occasionally among the hill-fastnesses at the lower end of the Greenwood Lake, on the frontiers of New York and New Jersey, none are to be found until we reach the western regions of Pennsylvania. And, in fact, as a bird of sport, they are not, any where on the eastern side of the great Apalachian chain.

The Deer and the greater American Hare, which turns white in winter, are likewise already extinct in many places, where both could be captured, within the last twenty years, in such numbers as to afford both sport and profit to their pursuers.

In New Jersey, and in New York, south of the forty-second degree of north latitude, with the exception of a small number carefully preserved on the brush-plains of Long Island, the Deer, Cervus Virginianus, has ceased to exist. And it requires no prophetic eye to see the day when this pride of the North American forest shall have ceased to have its habitation any where eastward of Pennsylvania; unless it be in the remote northern forests of Maine, in the mountains of New Hampshire and Vermont, and in that small district of $\mathrm{New}$ York, lying between the head waters of the Hudson, Lake Champlain, the St. Lawrence, and the exstern extremity of Ontario-which latter tract, owing to its singularly rugged and unproductive character, will probably contain the Deer, the Moose, the Cariboo, the Panther, and 
even the Beaver, after they shall have become extinct, even in the far West.

It has been alleged, and by many is doubtless believed to bo true, that the increase of population, the spread of cultivation, and the transfiguration of the woods and wastes into corn-lands and pastures, are in themselves an all-sufficient and irremediable cause for the disappearance of all the various kinds of game, the extinction of which the sportsman and the naturalist alike deplore.

Were this the case, it would be needless to waste words on the subject-but so far is it from being the case, that with regard to very many kinds of game-several of those already cited, and others, which, though still numerous, will ere long be in the same predicament, so rapidly are they decreasing-the very converse of the proposition is true.

The Wild Turkey, the Pinnated Grouse, and its congener, the Ruffed Grouse, as also the much rarer bird of the same orler, commonly known as the Spruce Partridge-the very existence of which was unknown to Wilson-all unquestionably do maise their homes in the wilderness, the last-named there exclusively. But all the others, without exception, prefer the vicinity of cultivated regions on account of the plenty and choicer quality of the food; and are found nowhere in such abundance as in those localities, which afford the combination of rough wild lyingground, with highly cultivated land, on which to feed at morn and dewy eve.

Thus, in the Eastern States, if you are in pursuit of the Ruffed Grouse, the surest places where to flush your game will not be the depths of the cedar swamp, or the summit of the mountain horrid with pine and hemlock, but on the slopes and ledges falling down to the cultivated vales, and in the skirts of briary woodlands, or in the red-cedar knolls, which remain yet unshorn in the midst of maize and buckwheat fields, which never fail to tempt this mountain-loving bird from his native fastnesses.

In like manner, in the West, it is on the prairie, but in the vicinity of the boundless tracts of maize and wheat, which the industrv of the white man has spread out over the hunting 
grounds of the Indian, that the Pinnated Grouse is to be found in millions; and the Turkey in similar situations, where the forest encircles the yet isolated clearings of the agricultural pioneer.

Thus, of these three species, it is untrue that the spread of cultivation, unless in so far as that involves the increased numbers and increased persecution of the cultivators, has any detrimental effect on their propagation, or in anywise tends to decrease their numbers. For centuries yet to come, let American industry develope and extend American agriculture as rapidly as it may, there will be woodlands and wilds in abundance to furnish shelter for any quantity of game; and there will always be fastnesses innumerable, which never will, because they never can, be cleared, owing to the roughness of their surface, and the sterility of their soil, whether from elevation above the sea, rockiness or swampiness of situation, or other natural causes, which it needs not to enumerate.

Other species of game, so far from flying cultivation, or abhorring the vicinity of civilized man, are literally not to be found except where the works of the ox and the man are conspicuous; never being seen at all in the wilderness proper, and giving cause for some speculation as to their whereabouts, their haunts, their habits, if not their existence on the continent, previous to the arrival of civilized man, from realms nearer to the sun.

Neither the Woodcock nor the Quail, Scolopax Minor, and Perdix, sive Ortyx Virginiana, are ever found in the depths of the untamed forest, aloof from human habitations; though both gencra frequent, nay require, woodland, as a sine quâ non, for their habitation. Moreover, in places where they are entirely unknown to the first settlers, where they do not in fact exist at all, they speedily become abundant, so soon as the axe levels the umbrageous forest, and the admitted sunbeams awaken or mature the germs of that animal or vegetable life, on which the birds subsist.

This is, I presume, so generally known as a fact, that no proof thereof is necessary I may, however. mention two or thref. 
very distinct and remarkable instances of this fact, which have come under my own observation; one with regard to the increase and spread of Quail, the others of Woodcock, into localities where they were previously unknown. Some seventeen years ago, I visited Niagara Falls for the first time, and travelled westward so far as the upper waters of the Thames and the Chenail Ecartè in Canada West, shooting a little when occasion offered, and making many enquiries concerning the varieties of game, and the habits of those to be found in the province. At that time, I enjoyed some extremely good Snipe shooting, close to the village of Niagara, at the embouchure of the river into Lake Ontario ; and, in fact, I saw more birds, and those tamer, than in any other place where I have ever shot them. I had no dog with me, and was completely ignorant of the country; but in such multitudes were the Snipe feeding in every fallow-field and maize stubble-it was in the spring, immediately on the breaking of the frost-that I made a very large bag, in the course of a very few hours. At that period, the Woodcock was just becoming known on the frontier; and a few birds were killed in the season; they were, however, still extremely rare, and had been known, comparatively speaking, but a short time. Quail were utterly unknown, both in the Province and on the American side of the river. I had not journeyed many miles, ere 1 had outstripped the Woodcock; and I could gain no tidings of his existence beyond the Ouse, or Grand River of the Mohawks. At this moment, probably, the best Woodcock shooting on the continent is to be obtained in the islands situate at the western end of Lake Erie, in the Detroit River, and in Lake St. Clair. Quail are also Lecoming exceedingly plentiful throughout that region.

In the same manner, in the Eastern States, until within the last six years, the Woodcock has been unknown on the Penobscot River, although abundant in the vicinity of Portland and Casco Bay, and in the older settlements on the Kennelec. What renders it more evident, in the latter case, that it is tle absence of civilization and not the severity of the climate, which 
has so long deterred this bird of passage from visiting the eastern parts of Maine, is the fact that, in the British Provinces of New Brunswick and Nova Scotia, much farther to the northward and eastward, and in the old cultivated French country below and around Quebec, the Woodcock has long been an object of pursuit by the sportsman, and of attainment by the gourmet.

It may, therefore, be assumed at once, that the spread of agriculture and civilization, in themselves, has no injurious operation, but rather the reverse, on any kind of winged game; and that, in some instances, the progress of one is simultaneous with the increased numbers of the other.

Even with game of the largest kind, as Deer, Bear, Hares, and the like, it is not the circumscription of their limits by ploughed fields, but the ruthless persecution to which they are subjected, which is gradually extinguishing them, where, within ten or fifteen years, they abounded.

In the counties of Hampshire and Berkshire, in Massachusetts, of Dutchess, Putuan, Rockland and Orange in New York, and of Sussex, in New Jersey, there is an extent of forest land, wilder and more inaccessible, and in every way more suited to harbor herds of Deer, and ten times greater, than all the Deer forests in the Highlands of Scotland; in the former, you have perhaps rather a greater chance of meeting an elephant, thanks to the abundance of menageries, than a hart or hind-in the latter, the Ked Deer are more numerous now than they were two centuries ago.

Hence it is evident, that there is no natural reason whatever, inuch less a necessary or inevitable one, for the rapid decrease and approaching extinction of all kinds of game, whether large or small, throughout the United States of America. Nor is it to be attributed to any other cause than the reckless and ignorant, if not wanton, destruction of these animals by the rural population.

The listruction of the Pinnated Grouse, which is total on Long Island, and all but total in New Jersey and the Pennsylvania oak-barrens, is ascribable to the brutal and wholly wanton havoc committed among them by the charcoal-burners, who fre. 
quent those wooded districts; and who, not content with destroying the parent birds, at all seasons, even while hatching and hovering their broods, shooting the half-fledged cheepers in whole hatchings at a shot, and trapping them in deep snows-with a degree of wantonness equally barbarous and unmeaning, steal or break all the eggs which they can find.

To this add the spring burnings of the forest land, and you have cause enough to account for the extermination of the Pinnated Grouse, or Heath-Hen; who is not now to be shot in such numbers as to render it worth the while to hunt for him nearer than Michigan or Illinois.

I should, perhaps, here state as a farther proof of the correctness of my assertion, that, on the little island of Martha's Vineyard, off the coast of Massachusetts, where the Heath-Cock, once abundant, had nearly become extinct, the species was preserved from annihilation by the very praiseworthy means, equally determined and energetical, adopted by the citizens in general to prevent its extermination.

This fine bird is again plentiful in that, its last locality, on the Atlantic coast; and it is like to remain so, as the people take an honorable pride in preserving it, and neither kill it themselves, nor allow visitors to do so, except in the proper seasons, and under restrictions as to numbers. For a space, I believe, of five years the prohibition to kill was absolute; and the fine so heavy, and so rigorously enforced-backed as it was by public opinion - that the desired end was gained.

The period, if I am not mistaken, for which the Grouse barrens were closed has expired, and, under some limitations, of the the nature of which I am not exactly aware, they may be visited by sportsmen henceforth.

The destruction of the smaller and more abundant species is to be attributed to different reasons-but the operation of these is more rapid and more fatal than those which have led to the extinction of the races we have mentioned.

The first of these causes is the very singular, if not incomprehensible, characteristic of the people of the United States, to dis- 
regard and violate all laws, even laws of their own making - the second, the apathy of the rural population with respect to game, and the error into which they have fallen of regarding all gamelaws as passed to their detriment, and for the pleasure of the dwellers in cities-the third is, the dishonest gluttony of all classes in the cities, with the exception of a few sportsmen-and the last, horresco referens, the selfishness and want of union among themselves of genuine sportsmen.

With regard to the first of the reasons laid down here, it may be taken as a matter of fact that no man, boy or fool, in the country, abstains from killing game, in or out of season, for fear of the law ; and that no farmer or landholder will ever give information against the violation of this law, though so far is he from being non-litigious, that one of the principal pleasures of his life is the sueing his neighbors for the smallest possible sums. The exceeding fondness of the population in general for recourse to civil, and their equally evident disregard of criminal, law, is one of the phenomena of the country, and the age in which we live.

Secondly; the apathy of the farmer arises naturally enough from this, that all he has heard of game-laws in foreign lands is in connection with feudal rights, individual privileges, and nominal distinctions, which are certainly everywhere more or less vexatious, and in some places really injurious to classes-although far less so than Americans are led to believe by the demagogue orators and editors from whom they obtain their information on this topic, as on most others of the internal economy of foreign countries.

It is needless to state that the game-laws of the United States have no such bearing whatsoever; and are intended solely to protect the animals in question, during the periods of nidification, incubation, and providing for the youthful broods.

Remarkably enough, it has so happened in this country, owing to the non-residence of wealthy and otiose men in the rural districts of the Northern States, that until very recently all application for and amendments of game-laws have emanated from the dwellers in cities; and, for this obvious reason, that the coun- 
try farmers, as a body, have neither the time, the inclination, nor the opportunities for making themselves acquainted with the names, habits, or manners of garne-animals ; and consequently could not, if they would, have framed adequate laws for their protection. I believe that if they could now be brought as a body to understand that the provisions of these laws are not arbitrary, and intended to suit the wishes of classes, they might be induced to lend their hand to the good work of game-preservation.

A very few years since, the sportsmen proper-those I mean who shot for exercise, pleasure, and healthful excitement-and the poachers who shot for the markets, both coming from the cities, were the only enemies of the Quail and Woodcock. They were at that time entirely disregarded by the farmers, who had not the art to kill them on the wing, who did not care for them as delicacies, or articles of food, and who had no markets to supply with what they considered useless birds. So great was the extent of this disregard, that I have repeatedly, on firing a great number of shots in small pieces of woodland, been questioned by the owners what on earth I found to shoot at; and, on showing some twenty or thirty Woodcock, have been met by a remark that the speaker had lived on that farm all his life, and had not seen a dozen such birds in his life-time-and the name of the bird was unknown to them.

At this period, which was the golden age for the sportsman, travelling was, comparatively speaking, expensive; it was often necessary, in visiting out-of-the-way places, where the best sport was to be had, to hire private conveyances; and the consequence was that the city poacher was in a great measure precluded from following his barbarous and dishonest trade. Add to this, that the country people were averse to the market-shooter, when they discovered his object, and cast obstacles in his way.

All this is now changed-the rail-roads by which the country is everywhere intersected, enable the city pot-hunter to move about with his dogs, and to transmit the subject of his butcliery to the market easily, cheaply, speedily. Nor is this all-the cuuntry now bids fair to monopolize the trade of pot-hunting. 
The young men and boys, now-a-days, all shoot on the wing; many of them shoot extremely well; and knowing the country, and being at it all the time, the devastation they make is enormous.

Their garne is easily disposed of by the aid of the conductors, or other employés on the rail-roads, who share the spoils with the killers. The father, finding that the idle lad, who formerly did an hour or two of work, and bird-nested or played truant quite unprofitably all the rest of the day, now readily earns his three or four shillings a day by loafing about the woods with a gun in his hand and a cur at his heels, encourages him in this thoughtless course, and looks upon him as a source both of honor and profit to the family.

In the meantime, knowing nothing, and caring less than nothing, about the habits or seasons of the birds in question, he judges naturally enough that, whenever there is a demand for the birds or beasts in the New York markets, it is all right to kill and sell them.

And thanks to the selfish gormandizing of the wealthier classes of that city, there is a demand always; and the unhappy birds are hunted and destroyed, year in and year out, by the very persons whose interest it is to protect them, if it be only for the selfish object of making the most money of their killing.

Even now, while I write these lines-February, 1848-owing to the mildness of the winter, which has allured them earlier than usual from their hybernacula in the swamps of the sunny South, the Woodcock are here among us, preparing their nests already ere the snow is off the ground. Each pair of these birds, if unmolested now, will raise eight young-perhaps twelve-during the season. The bird, moreover, is in no condition at this time of year-his plumage is full of a species of louse, his flesh is unsavory, he is thin and worthless-yet the ostentation, rather than the epicureanism of the rich New Yorker demands Woodcock; therefore, despite law, common sense, and common humanity, the bird is butchered at all times-even now. Within ten years to come, if some means widely different from any now 
adopted be not taken to save this bird, it will be extinct everywhere within a hundred miles of the Atlantic seaboard-and inland, everywhere within a hundred miles of any city large enough to afford a market. Within fifty years from the day on which I now write, I am satisfied that the Woodcock will be as rare in the eastern and midland states, as the Wild Turkey and the Heath-Hen are at present.

The Quail will endure a little longer, and the Ruffed Grouse the longest of all-but the beginning of the twentieth century will see the wide woodlands, the dense swamps, and the mountain sides, depopulated and silent. I begin to despair-to feel that there is no hope for those who would avert the evil day, when game shall be extinct, and the last manly exercise out of date in the United States of North America.

The foregoing remarks contain, in brief, the reasons which have induced me to prepare and offer to the public the present work, on "the Field Sports of the United Stales, and the British Provinces of North America"-a work, the intention and character of which, I shall take this opportunity of stating, are entirely different from those of any book heretofore published in this country.

"In all European countries," I remarked, in connexion with the observations quoted above, "writers on all branches of sporting have long abounded; many of them of high birth, many of them distinguished in the world of science and of letters, and some even of the gentler sex. The greatest chemist of his day, Sir Humphry Davy, was not ashamed to record his piscatory experiences in 'Salmonia,' a work second only in freshness and attraction to its prototype, by old Isaak Walton. That fair and gentle dame, Juliana Berners, deemed it not an unfeminine task to indite what, to the present day, is the text-book of falconry; and hapless beautiful Jane Grey thought she had given the exrremest praise to Plato's eloquence, when she preferred it to the music of the hound and horn in the good greenwood. Till the last few years, however, America has found no son to record the feats of her bold and skilful hunters, to build theories on the results of 
their experience, or to plead the cause of her persecuted and almost exterminated game.

"Within the last few years, indeed, much has been done. A whole host of sporting writers have sprung up in all quarters of the land, having their rendezvous and rallying point in the columns of the New York Spirit of the Times.

" Still, most of these writers have aspired rather to entertain than to instruct; rather to depict scenes and incidents to the life, than to draw from those scenes a moral and a theory."

Even the beautiful edition of that admirable English work, "Hawker on Shooting"-prepared for the American reader by my excellent friend, William T. Porter, known throughout the length and breadth of the continent as a thorough and accomplished sportsman-does not descend to those minute details of the zoological distinctions, nomenclature, and habits of our various species of game, which I propose to give to my readers; nor - though abounding with graphic accounts and highly colored anecdotes relating to every species of shooting or hunting, does it present any views or suggest any means for the preservation of game, or for the acquisition of skill in woodcraft and gunnery in this country-both being very different on this from what they are on the other side of the Atlantic.

This consideration-connected with another, namely, that for the last two years hardly a week has passed without my receiving a letter from some person addicted to field sports, in all, even the remotest, parts of the country, requesting me to suggest some plan for the prevention of, what all see to be imminent, the total annihilation of game within our borders-has led me to believe that the time has arrived, when a work of this character is called for by the country in general, and is likely to be as well received as the deficiencies of its author will permit.

And now, after these brief introductory observations, I shall state what is my plan for the arrangement of this work, and thereafter plunge at once in Medias Res.

In the first place, I propose briefly to ascertain what are the game of the United States and Provinces of America-a point 
which is, by the way, of no small consequence; as it is not by any means generally understood, at least by the rural portion of our eastern and midland sportsmen; and as, until it is understood and the understanding acted upon, sportsmanship never can be placed on a scientific footing.

This done, I shall classify it under its three great distinct divisions, of Upland or Inland, Coast or Sea, and Western Shooting.

Under each head, I shall give full descriptions, selected from the best authorities in natural history and ornithology, of the genera, the colors, habits, breeding seasons, and haunts of every species of game-thereafter, I shall treat of the proper scientific modes of killing and preserving them; and, last not least, I shall insist on the proper nomenclature, urging its adoption with all my poor powers, and endeavoring to abolish the vulgar, ignorant, slipshod habit, which prevails to such a terrible extent, of using absurd provincial misnomers for almost every animal of the chase.

Of the science of gunnery, the training and pathology of dogs, the acquisition of the art of shooting flying, and other kindred topics, so much has been stated at length by Hawker, Youatt, Blaine, and other great English authorities, that it is not necessary that I should be very diffuse in my observations. As, however, no work on field sports can be perfect, or approach to perfection, unless it include these vital subjects, I shall of course not pass them over in silence, though I shall dilate only on such parts of them as appear to be most desirable, either for want of sufficient present publicity, or from peculiar applicability to the circumstances of field sports in America.

Hunting, or coursing, proper, does not exist on this continent; the great topics, therefore, of condition, training, summering, and riding hunters to hounds, are, of course, out of the question; as well as the kindred subjects of the management of greyhounds, kennel-treatment and hunting of hounds, and lastly, all connected with the noble science of falconry, once termed "the Mystery of Rivers."

I have, indeed, often wondered that both falconry and coursing have not been introduced on the boundless prairies of the 
West, which, for the perfection of the first named sport, are the grounds pur excellence of the whole world-the decline of falconry on the continent of Europe, and in England, being caused by the multiplicity of enclosures, which renders it impossible to pursue a chase, blindfold as it were, the eyes being fixed constantly on the manœuvres of the hawk to pounce, and of the quarry to evade his stoop, in the mid-air.

Again, Deer-coursing might be practised with undoubted success on the prairies; the best proof of which is in the fact, that it has been tried by one gentleman at least, who has inported the rough Scottish deer greyhound for the purpose, in the extreme West; and has been found by him to surpass all his expectations, both for the excitement of the chase and the great sport attained. Deer, of the largest size and finest head, were run into, after a pursuit of three miles or more, in view, and pulled down single-handed-nay, even the enormous Elk was brought to bay unerringly, by these staunch, fleet and noble hounds.

With regard to these sports, however, I have said my say, and only expressing my wonder that they should not be adopted, and my advice to all genuine Western sportsmen-I do not mean game-butchers-to adopt them with all due speed-I pass un to what more claims attention.

Fishing is, perhaps, scarcely a field sport; it is nevertheless so decidedly a branch of sportsmanship-of course I mean flyfishing, or trolling with the live or dead minnow; any other mode I can regard only as I would knocking a hare on the head in her form, or shooting a bevy of Quail running, or in a huddle -that I may not leave it unnoticed, lest 1 should he supposed to rob it and its votaries of the honor due to the gentle science.

I know not, whether, before entering on my subject, I owe any apology to my readers for that $I$, not native or to the manor born, should aspire to treat of a subject so purely indigenous as the field sports of America Should it be deeined presumptuous in ine to attempt it, I must only point, as my excuse, to seventeen years of apprenticeship honestly devoted to acquiring the lit- 
tle I do know of American field sports-and so infinitesinal is that little, that I am almost compelled to own, with the sage of old, "all that I do know is, that I know nothing"-and to a constant and long-maintained habit of intercourse and familiar correspondence with better, though not more thoroughgoing, sportsmen than myself, in every part of the United States, and of the Provinces.

Upon any general defence of field sports I do not here think it worth the while to enter. All men whose opinions are worth one moment of attention, have long ago decided that they are the best, the manliest, and the most desirable, in every respect, of national amusements, tending to prevent the demoralization of luxury, and over civilization, the growth of effeminacy and sloth, and to the maintenance of a little manhood in an age, the leading characteristics of which are fanaticism, cant, and hypocrisy, added to a total and general decay of all that is manly or independent either in the physical or moral characters, alike of individuals or nations.

To those who think field sports cruel, immoral, wicked, and brutalizing, I have only to make my lowest bow; and to entreat that they will give me and my book, as I shall assuredly give them and their opinions, the widest possible berth; assuring them that, without the slightest respect for their opinions, 1 have no idea of intruding upon their premises, nor any desire to convert them from their comfortable and self-hugging creed.

In all ages and in all countries, genuine field sports-from which I, of course, exclude the really cruel and brutalizing amusements of bear-baiting, dog-fighting, cock-fighting, and other similar pursuits, which are for the most part followed only by the vicious and worthless population of large citieshave been approved of and encouraged by the wisest men, by statesmen and philosophers and philanthropists, not merely as legitimate pursuits whereon to expend and exercise the buoyant animal spirits, and ardent animal propensities of youth -which must have an outlet one way or another-but as the best mode of preserving the combined advantages of the mens 
sana in corpore sano-of keeping up manhood, and of maintaining the physical energies and capacities of the human race at their highest standard.

It is an authentic and undeniable fact that the aristocracy and gentry of the British Islands are superior, in physical beauty and power, in robustness, agility, and the capacity of enduring fatigue, to any other class of nolbility in the world. They are, in fact, the only nobilily in existence, which have been enabled to resist the deteriorating influences of wealth, luxury, and breeding-in-and-in, which have corrupted and effeminated the nobility of all other lands; they are the only nobilily, in existence, which not only equals, but exceeds, in physical stature and strength the peasantry and laborious classes of their own country. And to nothing is this, or can it be, ascribed, but to their habit of residence on their rural estates, and their addiction to manly and laborious field sports. To the like cause, may be, in its degree, attributed the superiority, in vigor and robustness, despite of ill fare and hardship, of the British peasant and artisan to his equal in society, in France, Spain, Italy, and on the European continent in general.

This being, as it must be admitted, true of Great Britain, there are two reasons, worth the consideration of the statesman and the philanthropist, why the encouragement of a love for field sports is even more desirable and necessary in the United States than in that country.

'The first is this-that the wealthy classes of the northern states enlirely, and of all the states, in a great degree, dwelling exclusively in large cities, and not residing at all on rural estates, or acquiring rural tastes and habits, are infinitely more liable to become effeminated and effele than the gentry, not of Britain only, but of France and Germany. And, in fact, the soi discmle aristocracy, the dandies of our cities, are now softer and more cocknified, as a rule, than the gentry of the European inonarchies.

The second consideration is this-that, standing armies being out of the question in this republic, the defence of the land an' 
its institutions must ever be intrusted to the people at large; and the adaptibility of the people to that defence will ever depend on their aptitude to become soldiers at a short notice, and especially on their readiness with the gun.

So far as they have been tried hitherto, nothing can be more satisfactory than the results. But, I think, it will appear, on a little consideration, that the probability of those results continuing the same for a large term of years, as far as regards the use of the gun, is small indeed and hourly decreasing.

During the war of the Revolution, every countryman was a rifleman. Burgoyne surrendered as much to the unerring aim of the undisciplined Aınerican inilitia, as to the skill or courage of the regulars. Even in the last war, the northern and midland states could produce their hundreds and thousands of rifle shots ; and on the Canada frontier they did good service.

Along the Atlantic sea-board the rifle is now, already, an unknown arm; and I doubt extremely whether, between the Kennebec, the Delaware, the great lakes, and the ocean, one regiment could be raised of men practically familiar with the use of this deadly national weapon.

According to this rate, the use of the weapon, of course, passing away so soon as its utility passes, the rifle will ere long be as rare in the western, as it now is in the eastern states. The Bison, the Elk, are already rare on this side the Mississippi, if not extinct. The Deer are, in the same ratio, declining, and the Turkey.

These gone, the utility and honor of the rifle are extinct also

So long as smaller game exist, the shot-gun will still continue, replacing the rifle as it has done to the eastward, to be in use ; and the practice of fire-arms will not be wholly lost. Destroy the small game, too, and the fowling-piece falls into disuse also.

I do not myself believe that one century will pass over the United States, before its population, now the readiest on earth with the gun, will have cast it aside altogether; and before a frrclock will be as rare, unless in the hands of trained regulars, as $\mathrm{tl}$ :e rifle is now on the sea-board. 
This certainly is a point worthy of consideration, even by those who think themselves far too great and philanthropical to trouble themselves about such trifles as the increase or decrease of little birds, and the field sports of little men. It is, however, sound philosophy which teaches us that "great ends come from small beginnings." 


\section{THE G A M E}

OF THE

\section{UNITED STATES AND BRITISH PROVINCES.}

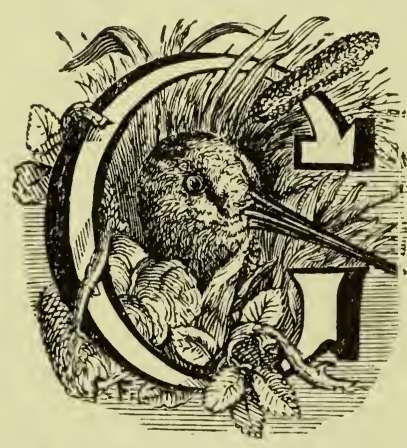

AME is not every thing which exists in the shape of birds or beasts in a state of nature, ferce naturâ, in the woods, the wastes, or the waters.

This, to sportsmen, self-evident proposition is by no means generally admitted or applied by the gunners of the United States, or the recorders of their feats; as will

be readily seen by those who peruse the registers of game killed, in the great hunting parties which are constantly occurring in the more remote districts of the Eastern and Midland Statesregisters in which we shall find Owls, Hawks, Bluejays, Robins, Pigeons, Squirrels ; nay, even Skunks, Ground-hogs, and Opossums enumerated as game.

Game is an arbitrary term, implying, in its first and most correct sense those animals, whether of fur or feather, which are the natural pursuit of certain high breeds of dogs, and which such dogs, whether they have ever met with the animal before or not, will instinctively follow and take.

Thereafter, it comes to signify all animals which are so pursued by dogs for the purpose of sport, not of obtaining food, or of destroying a noxious animal merely, and to which certain courtesies, if I may so express myself, are shewn, and certain semichivalrous usages extended. 
At the sane time, with but two exceptions that occur to me, " animal can properly be game which is not fitted for the table, and the flesh of which is not delicate, and esteemed a rarity.

Again, although it be an essential qualification to game that it should be such as a well-bred dog will notice, and pursue naturally, it is not necessary that the dog should be invariably used in its pursuit-as in the case of the Water-Rail, and the Upland or Bartram's Plover ; on both of which thorough-bred dogs will stand steadily, although, for reasons of which I shall treat under their appropriate heads, it is not usual or desirable to take out pointers or setters in pursuit of them.

Once more, to conclude, there are animals which may be re garded as game, under certain contingencies and in certain countries, which I should not call game under different circumstances.

Where falconry is in vogue, for example, which is purely a sport, and a most scientific sport, too, the Heron, the Skylark, nay, even the Magpie is pursued as, and may be considered, game.

In like manner, where packs of Fox and Otter hounds are regularly kept for the purpose of hunting those animals, legitimately and scientifically, and where to kill those animals otherwise than legitimately and scientifically, is contrary to sportsmanship and custom, the Fox and the Otter may be properly termed garne.

In England I should certainly term the Fox an animal of garne; in those counties of England, wherein Otter hounds are kept up, the Otter likewise.

Here, like the other noxious animals, or those which are killed for their peltry only, by the trap or the gun, they are vermin; as are the Racoon, the Opossum, and the like, although these may be casually pursued, unscientifically, and without fair play, or regular rules of sportsmanship, for their flesh, or ever: for sport.

Game, therefore, in its proper sense-and in no other do I treat of it-consists but of a few families, and even genera, voL. I. 
though of many species; and in the United States and British Provinces of North America, these families may be limited to six families of quadrupeds only, containing twelve sub-genera and species; and this at the very largest and most liberal computation. These families are the Ox, Bos; the Goat, Capra; the Antelope, Antilope; Deer, Ccrvus; Hare, Lepus; and the Bear, Ursus

Of the first, second and third of these genera, there are but three species found on this continent, one of each.

The Bison, Bos Americanus, peculiar to South Arnerica.

The Rocky Mountain Goat, Capra Montana.

The Rocky Mountain Sheep, Ovis Montana; and

The American Antelope, or Pronghonn.

Of the Deer there are five varieties found in the territories of the United States and the Provinces, namely-

The Moose, Cervus Alces;

The Elk, Cervus Canadensis;

The Cariboo, American Reindeer, Cervus Tarandus;

The Common Deer, Cervus Virginianus; and

The Black-Tailed Deer, Cervus Macrotis.

Of the Hare there are two varieties known on this continent: The Common Hare-vulg. Rabbit-Lepus Americanus; and The Northern Hare, Lepus Virginianus.

Of the Bear also there are two varieties :

The Common Brown Bear, Ursus Americanus; and The Grisly Bear, Ursus Horribilis.

This is the utmost limit that I can assign to the quadruped game of this country; as I cannot lend my humble sanction to the shooting squirrels, racoons, or opossums out of trees, and calling that sportsmanship ; any more than I can assent to shooting thrushes, crow-blackbirds, pigeons, meadow-larks, and reedbirds, and calling them game.

In fact, for my own part, I can scarcely bring myself to regard the Bison or the Bear as game, in consequence of the whole- 


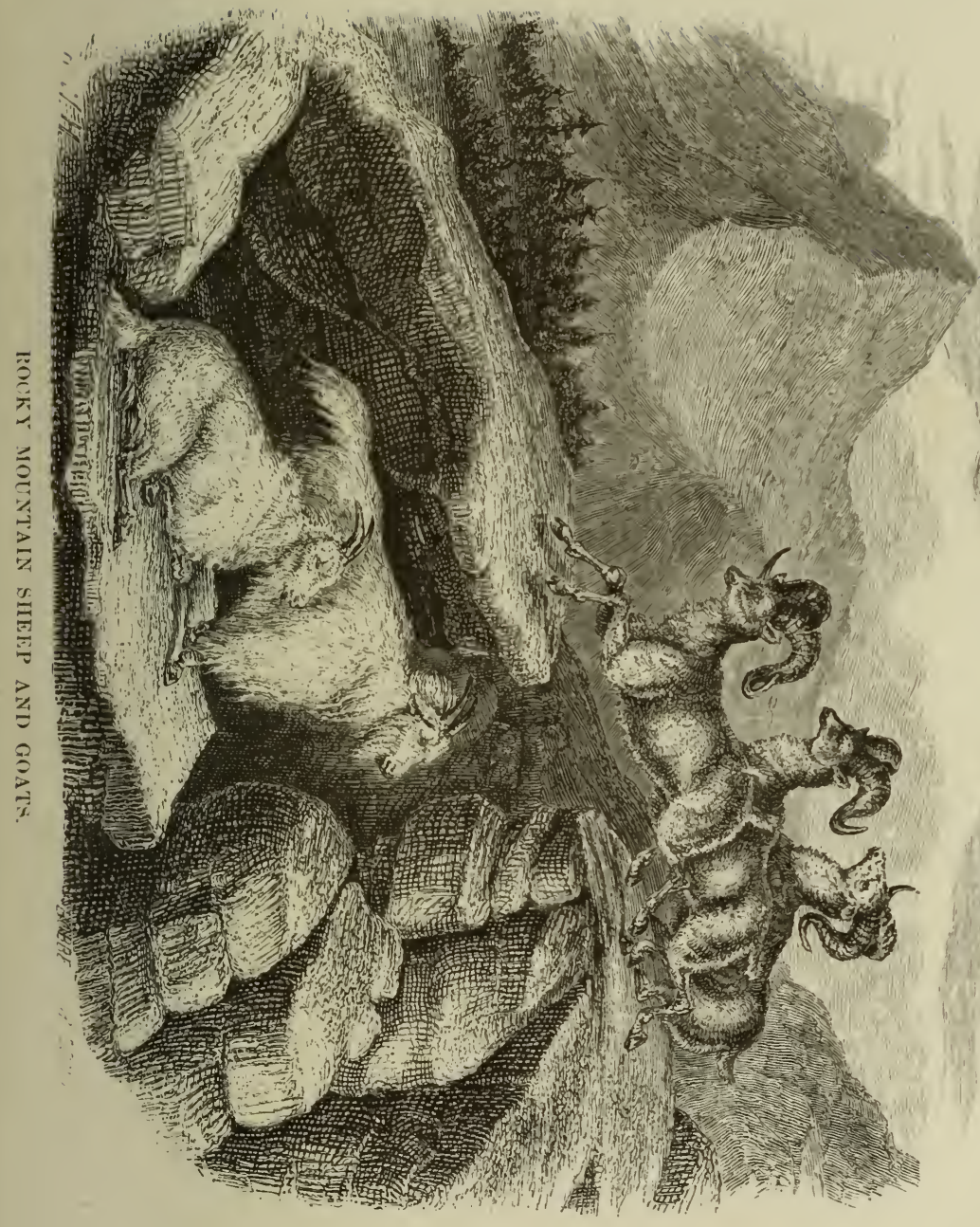



sale and butcher-like fashion in which the former are slaughtered, and the total absence of what I should deem sport in gallopping alongside of a great unwieldly terrified mountain of flesh, pouring broadsides into him, until he falls for loss of blood; and looking to the ferocious and noxious character of the latter.

Nevertheless, in the West, Buffalo-hunting is rerarded as sport-therefore the Bison-for, be it observed, there is no such animal known to this continent as the Buffalo-must take its place among the game of North America; and, in the south and south-west, the bear is hunted sportsmanly and scientifically with packs of highly-trained and highly-bred hounds. I cannot therefore, deny him a place in the list of animals of game or chase.

The Antelope again, and, yet more, the Rocky Mountain Sheep, are so rare, and so little pursued, except by the travellers and trappers of those barren wilds, who kill them-when they can-for their flesh, that they barely come within the sphere of game. There is no mode of hunting or pursuing them practised, except to crawl as near to them as you can, and shoot them if you can; still they are of species recognised as game elsewhere, which doubtless would afford rare sport, if they were in situations where they could be legitimately hunted; and perhaps will yet afford it, if they be not destroyed by the trappers and backwoodsmen, before increasing civilization and refinement brings up a class capable of indulging in the expensive pursuit, and of cherishing a fondness for sport, purely for sport's sake.

The Moose, the Elk, the Cariboo, and the Common Deer, are distinctly game in every sense of the word; and are pursued as such whenever they can be found. The black-tailed Deer is of precisely the same order, and will doubtless afford as good sport, when civilization shall have reached his haunts, which are on, and to the westward of, the Rocky Mountains.

The two varieties of Hare are likewise emphatically game; and it is with these two families only, and but with two or three species of these, that nine-tenths of my readers will ever have to do. 
The Mouse and Cariboo may be hunted with more or less success in Maine and Canada, as well as in the Eastern provinces of Nova Scotia and New Brunswick. A few linger yet in the north-eastern angle of New York, and on the northern frontiers of Vermont and New Hampshire. There is, how ever, little prospect of sport in their pursuit, west of the St. Johns, or south of the Canada lines. A few Elk are said to exist still in the western districts of Pennsylvania, and also in Kentucky, but to find them in herds, and in fact to have a chance of killing them, the hunter must go westward of the Mississippi.

Even the larger species of hare, which becomes white in winter, is becoming rare in New York south of the region of Lake Champlain; and, except among the craggy hills where he can laugh at pursuit, he will soon cease to exist as an animal of chase.

So that in fact for the great majority of sportsmen, the number of varieties of four-footed game is reduced to two species-the common Deer, and the common Hare-the small grayish brown fellow, I mean, who is erroneously called Rabbit-for be it observed no Rabbit exists on the continent of North America, and no Buffalo; though I suppose to all eternity, men will persisteven men of education, who ought to know, and do know, better -in calling them by the names applied to them by the illiterate and vulgar.

I have no patience with the dependent provincial vulgarism of calling all birds, beasts, plants and fishes, by the name of European animals or vegetables, to which they bear some fancied resemblance, when no such things exist on the continent.

There is scarcely a wild bird or a wild plant in this country that does not go by some ludicrous misnomer. Thus a Thrush is termed a Robin, a Vulture $a$ Crow, a Grouse a Pheasant or a Partridge, a Quail a Partridge - a Rhododrendon, an Azalia, and a Calmia-all three as wide apart from each other, and from the thing they are called, as an ivy bush from an oak tree-laurel; and so on, of almost everything that runs, flies or grows in the wuods or wilds of the United States. 
It is to those stupid misnomers, as I shall show hereafter, that one-half the confusion and difficulty arises among sportsmen with regard to the objects of their pursuit.

We now come to the winged game; and here we shall find less difficulty in deciding what species are properly game; though, with regard to one or two families, much more in ascertaining the correct denominations of the birds themselves, it being no easy task to assign the individuals known by some barbarous nickname to any real tribe or order.

All the game birds, proper, of this continent, then, belong to three orders; one of land, and two of - as they are called-water birds; although several species of the latter are found inland and on uplands.

All our game, coming under the head of land-birds, proper, are of the order termed by ornithologists Rasores; and belong to two families, Pavonida, and Tetraonida ; or birds following the types of the Peacock, and of the Grouse. Of these again we have three subdivisions-Meleagris, or Turkey; Ortyx, or American Quail ; and Tetrao, or Grouse.

Of the second* family Pavonide, and first genus Meleagris, the United States possess but one species.

\section{The Wild Turkey. Meleagris Gallipavo.}

Of the third family Tetraonide, and first genus, Ortyx, Quail, there are no less than six distinct species within the territories now belonging, or about shortly to belong, to the United States; and I think it well at least to mention their names and places of residence; as experience teaches us that our population spreads with such vast rapidity, that tracts, which are a wilderness one year, are the next almost thickly settled places; so that it is by no means impossible, nor even very improbable, that within a few years, more or less, these varieties of Quail, now known only to a few minute and laborious ornithologists, may be as regularly hunted and as scientifically killed as our own domestic bird of the same kin. They are thesegame.

* The first family, Columbida, of this order, the third of land-birds, are not 

1. The Common American Quall,
Ortyx Virginiana ;
2. The Californian Quail,
Ortyx Californica;
3. The Plumed Quail,
Ortyx Plumifera;
4. The Welcome Quail,
Ortyx Neoxena;
5. The Painted Quail,
Ortyx Picta;
6. The Douglass Quail,
Ortyx Douglasii.

Of these six species the first alone is yet an object of pursuit, being found everywhere south of the 43rd degree of north latitude, from the waters of the Kennebeck to those of the Rio Grande, if not yet farther to the south. The second, third, fourth, and fifth species are all inhabitants of California, as far north as the valley of the Columbia-the third, or Plumed Quail, being found farther north among the Rocky Mountains; and the last, named after its discoverer, being a denizen of Lower California only, and never straying so far northward as his congeners.

Still of the third family Tetruonida, we have in the United States and Canada, a second genus Tetrao, Grouse proper, of which three distinct and well marked species belong to the States, if not four. Two more, in addition to the above, inhabit the British provinces, and thence northward to the Arctic Ocean; and four others are peculiar to the Rocky Mountains, and the valley of the Columbia. Three of these species are tolerably plentiful, and two of them $I$ have myself shot, the one being the Ruffed, and the other the Canada Grouse, respectively vulgarised, as the Partridge, and Spruce Partridge.

Within a few years, there is little doubt that the western species will be exposed for sale in our markets; and, should Whitney's Oregon Railroad go into effect in our days, who knows but we may live to shoot Cocks of the Plains ourselves, and bring them home the next day to dinner at Delmonico's?

The ten American species of Grouse are as follows:

1. The Common Ruffed Grouse, Tetrao Umbellus;

2. The Pinnated Grouse-or the Heath-Hen, Tetrao Cupido,

3. The Canada Grouse-or Spruce Grouse, Tetrao Canadensis;

4. The Dusky Grocse, Tetrao Obscurus : 
5. The Cock of the Plains, Tetrao Urophasianus;

6. The Sinarp-talled Grouse, Tetrao Phasianellus;

7. The Willow Grouse, Tetrao Saliceti;

8. The American Ptarmigan, Tetruo Mutus;

9. The Rock Ptaruigan, Tetrao Rupestris; and

10. The White-tailed Ptarmigan, 'Tetrao Leucuras.

Of these noble birds, the three species first named are all natives of the Eastern States, and a few of all are yet to be found in them; although the Pinnated Grouse, or Heath-Hen, has been nearly exterminated-as I have before observed-and the Canada or Spruce Grouse, is a shy, forest-haunting bird, rarely met with, and scarcely ever pursued on his own account alone. I never saw but one alive, which I shot on the Penobscot, in Maine. It is, so far as I can learn, nowhere plentiful, not even in its northern haunts.

The seventh species, the Willow Grouse, is stated in the books to exist from Maine to Labrador. I never, however, have heard of one being killed, or seen south of the St. Lawrence, above Quebec. If it be found in the States, it is so rare as to be unworthy of notice, as a species of gaine.

The fourth, fifth, sixth, and tenth varieties are indigenous to the Rocky Mountains and the valley of the Columbia, and will probably be, one day, added to the list of American game, and fairly pursued, as such.

The eight and ninth inhabit the desolate regions northward of Labrador, and Melville Island, and the banks of the Churchill River, where no one is very like to follow them in search of sport. Few of our race have ever seen them living, and they are of course incapable of naturalization to the southward.

And here ends the list of our game land-birds, proper-although as I have stated, two or three varieties of those which are classed by the naturalist as water-birds, and which are in some sort amphibious, fall under the sportsinan's head of Upland shooting. It is on account of this peculiarity, that I propose, after enumerating and classifying the game of the country in general, in its proper orders, families, and genera, to distinguish 
it farther according to the regions and situations in which we find it, and the modes we adopt in its pursuit.

Of game land-birds, proper, then, we have in all but THREE genera, the wild Turkey, the Grouse, and the Quail. Here specially observe and remember that on the whole continent of America there exists neither Pheasant nor Partridge; and to call the Ruffed Grouse, or American Quail, as both are called, by those names, is not an iota less absurd than it would be to call them Game-cocks, and Bantams.

Moreover, of all the various species both of Grouse and Quail, conimon to this country, there are but two of the former, the Ruffed and Pinnated, and one of the latter, the commun Quail, sufficiently abundant in any part of the United States or Canada, to render it worth the sportsman's while to pursue them.

Of water-birds, to proceed with our enumeration, we have a a nuch larger number coming under the head of game; all of two families, Grallatores, or waders, and Natatores, or swimmers. 'The first, third, and fourth families of the first of these orders, the waders, include some of our choicest and most favorite varieties of game, both for the excellence of their flesh, and the sport they afford in the field.

They are the Rallida, the Charadriada, and the Scolopacida, or the families whereof the Rail, the Plover, and the Woodcock form the types. Of the second order, the swimmers, the scond family alone, the Anatida, of which the Duck constitutes the type, comes within the sphere of my notice as game; but five of its six genera-the first, containing the Flamingo, only being omitted-Goose, Swan, Duck, Sea-duck and Diver, contain more species than all the rest of our list together. But to proceed in order, of the first family Rallida, of the waders, we have two genera. Fulica, Coot, and Rallus, Rail.

1st. The Comnon American Coot, Fulica Nigra, which is a common autumnal visitant of all the coasts, bays and salt marshes from Pennsylvania eastward.

Of the Rail, three species are well known to all our sportsunคn 
1st. The Virginia Rail, Rallus Virginianus;

2nd. The Clapper Rail-Vulg. Meadow, or Mud, HenRallus Crepitans;

3rd. The Common Sora Rall, Rallus Carolinus, which is the bird killed in such abundance on the flats and reed-beds of the Delaware in autumn.

The second family of this order, the Gruida, of which the Crane is the type, containing all the varieties of Heron, Ibis, and Bittern, I do not regard as game; and therefore pass in silence. Of the next, third, family, Charadriada, we have all the genera but one, the Charadrius, Plover, proper, six varieties-the Strepsilas, Turnstone and the Hamatopus, Oyster-catcher, the last named hardly being entitled to the name of game, the others all, like four-fifths of the next family, being included under the vulgar appellation of Bay Snipe, or Bay birds. It is unnecessary, at present, to enumerate all the species of these genera, as, in truth, they are generally of small value, with perhaps one exception, the Golden Plover.

The fourth family, Scolopacida, contains almost all our best and most delicious species for the table, and those which are most eagerly pursued and most highly prized by the genuine sportsman.

All the genera of this family are game, and scarcely one but contains some favorite species.

The first is Tringa, Sandpiper, of which we have eight or nine varieties, classed indiscriminately with the next two genera, as Bay birds, by our gunners.

The second, Totanus, Tatler, contains seven species, all of which are common along the Atlantic seaboard, and four, $\mathrm{a}^{+}$ least, of which are universally known and general favorites.The first I regard, myself, as the best bird that flies, in an epicurean point of view, not excepting even the world-famous canvass back. The varieties are-

1. The Upland Plover, Grass Plover; or Frost Bird, Totanus Bartramius;

2. Semi-Palmated Snipe, or Willet, Totanus Semipalmatus; 
3. Spotted Tatler, Totanus Macularius;

4. Solitary Tatler, Totanus Solitarius;

5. Yellow Shanks Tatler, Lesser Yellow Leg, Totanus Flavipes;

6. Telltale Tatler, Greater Yellow Leg, Totanus Vociferus; and

7. Green Shanks Tatler, Totanus Glottis.

Of these the Upland Plover, the Willet, and the two Yellow Le gs are very general favorites. The first is an excellent bird; the others, me judice, are, nine times out of ten, uneatably fishy or sedgy.

The third genus, Limosa, Godwit, has but one species which visits us.

The Great Marbled Godwit, or Straight-billed Curlew, Limosa Fedoa, frequently killed with the Sandpipers, Plovers and Tatlers on the Long Island bays, and the shores of New Jersey.

The fourth genus, Scolopax, has three species known to every sportsman; two his most chosen game. They are-

1. Wilson's Snipe-vulg. English Snipe-Scolopax Wilsonii ;

2. Red-breasted Snipe - vulg. Quail Snipe-Scolopax Noveboracensis; and

3. The American Woodcock, Scolopax Minor.

The other genera, each containing one species, are the

Recurvirostra, Avosets ; Himantopus, Stilt ; and Numenius, Curlew; all of which are well known to our fowlers, though, with the exception of the last, all falsely termed Bay Snipe. ОвSERvE, that the Red-breasted Snipe of this family is the only Snipe which frequents the sea-beach or salt marshes; the other birds so called are Plovers, Sandpipers, Tatlers, Turnstones, Avosets, Phalaropes, and others, whose names are legion; but not a Snipe among them; and even the solitary Red-breasted Snipe lies under some suspicion of being rather a connecting link between the Snipes, proper, and the Godwits and Tatlers, than him. self a pure Snipe. 
We now arrive at the last order, Natatores, swimmers, of which, to take cognisance, under the head of its second family, Anatida. The second genus of this family, Anser, Goose, gives us four species, though two, the third and fourth, are far from common. The first and third are decidedly the best of our sea fowl.

1. The Canada Goose-Wild Goose-Anser Canadensis;

2. The Barnacle Goose, ${ }^{*}$ Anser Leucopsis;

3. The Brant Goose-Brant-Anser Bernicla;

4. The White-rionted Goose, Anser Albifrons; and

5. The Snow Goose, Anser Hyperboreus.

The third genus, Swan, affords two species to North America, but the second only belongs to the Eastern States; the Trumpeter ranging only through Northern California to the fur countries, from westward of the Ohio.

1. The Trumpeter Sivan, Cycnus Buccinator; and

2. The American Swan, Cycnus Americanus.

The fourth genus, Anas, Duck, contains ten species, every one of which, with the exception of the fourth, is well known to all sportsmen; they are of the finest quality for the table, and preferable to all others, with the exception of the Canvass Back, and perhaps the Red Head. They are as follows:

1. The Mallard-vulg. Green Head-Anas Boschas;

2. The Dusky Duck-vulg. Black Duck-Anas Obscura;

3. The Gadwall, Anas Strepera;

4. Brewer's Duck, Anas Brewerii;

5. The American Widgeon, Anas Americana;

6. The Pintall Duck, Anas Acula;

7. The Wood Duck, Summer Duck, Anas Sponsa;

8. American Green-winged Teal, Anas Carolinensis.

* I have my doubts whether the Barnacle and Brant are not one and the same bird, though at different ages, and in different states of plumage. 
9. The Blue-winged Teal, ${ }^{*}$ Anas Discors, and

10. The Shoveller, Anas Clypeata.

The fifth genus, Fuligula, Sea Duck, contains sixteen species, several of which are well known, and the two first prominent above their race. They are-

1. The Canvass Back Duck, Fuligula Valisneria;

2. The Red-headed Duck $†$-vulg. Red-head-Fuligula Marina ;

3. The Scaup Duck, Fuligula Marila;

4. The Ring-necked Duck, Tufted Duck, Fuligula Rufi-torques;

5. The Ruddy Duck, Fuligula Rubida;

6. The Pied Duck, Fuligula Labradora;

7. The Velvet Duck, Fuligula Fusca;

8. The Surf Duck, Fuligula Perspiculata;

9. The American Scoter, Fuligula Americana;

10. The Eider Duck, Fuligula Mollissima;

11. The Golden-eye Duck, Fuligula Clangula;

12. The Buffel-headed Duck, Fuligula Albeola;

13. The Harlequin Duck, Fuligula Histrionica;

14. The Long-tailed Duck - vulg. South-southerly-Fuligula Glacialis ;

15. The King Duck, Fuligula Spectabilis ; and

16. The Western Duck, Fuligula Dispar.

The sixth genus, Mergus, Merganser, contains three well known species, which, commonly shot and of rare beauty, are all nearly worthless as articles of food, so rank and fishy is their flesh. They are, as follows :

1. The Goosander-vulg. Sheldrake-Mergus Merganser;

2. The Red-breasted Merganser, Mergus Serrator; and

3. The Hooded Merganser, Mergus Cucullatus.

- I once doubted whether this Duck was not identical with the Garganey of Europe, Anas Querquedula, but am now satisfied that they are distinct birds.

t This I believe to be the same with the European Pochard. 
Here ends what may, I believe, be termed a complete list of all the game, both quadruped and winged, of the United States and the Provinces; I am not aware of a single omission; perhaps, indeed, in the latter portion of my catalogue, the fowl especially, I have admitted some genera, which are of so rare occurrence on the coast, as to fall seldom before the gunner's aim ; and which, therefore, can hardly be enumerated as regularly game. I judged it, however, better to err on this, than on the other side of the question; and the error, if error there be, will be rectified when I come to speak of the various kinds of shooting, and the habits of the animals pursued in each.

And here I should, perhaps, apologize to my readers for the apparent but necessary dryness of this part of my work. A catalogue never can be rendered entertaining, and yet it is indispensable. I think I can promise that future pages will possess more interest to the general reader, although I should strenuously urge it on him, whe desires really to make himself a master of the subject, not to skip or slur over the above list of names, but to fix them in his understanding and his memory, as I shall have constant occasion to refer to them hereafter, and as a knowledge of them is absolutely necessary to the acquisition of skill and science in field sports, in their widest range and most liberal signification.

I now come to the subdivisions of my subject, according to the different regions of country to which the different kinds of shooting and hunting, and the different species of game belong. These, it appears to me, are threefold, chiefly.

First. Upland shooting, which may be termed particularly the field sports of the Northern and Midland States, consisting in the pursuit of small game-as the Pinnated and Ruffed Grouse, the Quail, the Woodcock, the Snipe, the Upland Plover, the Hare, the Rail, and one or two species of Duck, which are found only on inland streams and marshes-with the double gun, and the trained pointer, setter, spaniel, or retriever.

Second. Fowl shooting, whether from sailing-boats, batteries, or otherwise; and, under this head, I include the killing of the 
smaller coast-birds, as Plovers, Sandpipers, and the like, over stools, as they are called, or decoy birds.

Third. Western shooting, which may be termed hunting, as it consists of the pursuit of the larger animals, as the Bison, the Elk, the Bear, the Deer, \&c., either with the aid of hounds or the speed of horses, but invariably with the rifle instead of the shotgun. Even the pursuit of the Turkey is a species of still hunting, or stalking, rather than of shooting proper; as I never have heârd of this bird lying to, or being killed over, setters, and not often of his being shot on the wing, or with the fowlingpiece. I am, of course, not unaware that all the smaller kinds of eastern game abound to the westward, but as the mode of killing them, over setters or pointers, is identical with that used on the seaboard, and is adopted thence, that does not, I think; militate against the justice of my distinction.

Lastly. The hunting of the Northern and Eastern States must, I suppose, find a place ; though, in truth, the deer-hunting is so idle and contemptible, now-a-days, in that part of the States, as to be hardly worthy of notice; while the pursuit of the Moose and Cariboo, although really a grand field sport, and a very noble exercise, requiring pluck, power, wind, sinew, speed, and endurance, is so rare and difficult of attainment, as to present little attraction to the general run of sportsmen.

Without farther comment I now proceed to Upland game and Upland shooting, connected with which I shall discuss, in their places, the use of the fowling-piece, the art of shooting flying, the breeds, breeding, diseases and management of dogs, and such other points as shall appear to flow naturally from the subject; and this I esteem the principal portion and better part of the work before me; and, as my own especial hobby and chosen sport, I come to deal with it, as a work of love and pleasure. 


\title{
UPLAND SHOOTING
}

\author{
OF THE
}

\section{NORTHERN STATES AND BRITISH PROVINCES.}

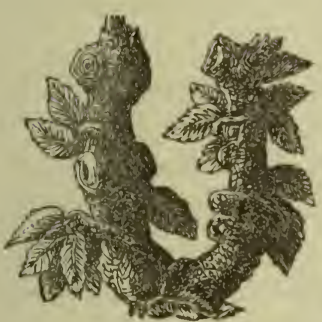

PLAND shooting, as it is understood by American sportsmen, is the distinctive term, not, as would appear at first sight, dividing the sport of the hill from that of the plain country, but that of the inland from that of the coast. It includes, therefore, not only all game of the order, Rasores, the home of which is in thickets, mountain-sides, stubbles, or maize-fields, but such also of the Grallatores, or warders, as dwell either in inland swampy woods, fresh meadows, or river-side morasses; and, farther yet, such of the Natatores, swimmers, as are found exclusively or principally on brooks, rivers, above tide water, and spring marshes.

By upland shooting, in a word, we understand all that is pursued with the aid of pointers, setters, or spaniels, and the ordinary light fowling-piece; as opposed to that which is followed in boats with heary ducking guns, and by the aid of decoys, or, as they are here termed, stools.

Of all sports of this country, therefore, upland shooting is that which requires in the sportsman the greatest combination of qualities, the greatest skill with the gun, the greatest knowledge of the habits and haunts of his game, the greatest science in the management of his dogs, and the greatest bndily vigor and endurance. 
The upland shooter of America does not, cannot, select his stands, or easy walking ground, for getting shots and killing game, leaving it to his gamekeeper or beaters to hunt his dogs, and flush his birds in the thicket, so that they shall fly out before his face-still less does he, like the deer shooter, remain listless and silent at his stand, until his guide, a practical woodman, shall find the quarry and hunt it toward him, so that, perchance, without walking fifty yards or making the slightest exertion, he gets his point-blank shot, and thinks it a great matter to have killed a big helpless animal, as big as a jackass, and as timid as a calf, literally in the intervals between eating bread and cheese and drinking brown stout, as he sits on a mosscovered $\log$ to leeward of the runaway.

No, through the thickest alder swamp, the deepest and most boggy marsh, among tussocks knee-high, and fallen trees, and interlacing vines and cat-briars-along the sharp limestone ledges and through the almost impervious growth of the rhododendron overcanopied by juniper and hemlock-over mile after mile of broad, bare hill-side stubbles-through black morasses, intersected by broad drains-trusting to his own sure foot and even stride, he must toil on after his game, the wildest, fleetest, wariest, and sharpest-flying of all the fowls of the air, depending on his own knowledge of their seasons and their habits to launch his trusty dogs into their proper haunts, at their proper hours; on his management of those dogs to flush them fairly within shot, and on his own eye and hand of instinct to give a good account of them, when flushed within distance.

The perfection to which some men have carried this art is almost incredible-the certainty with which they will find game on the same tract of land, with another party who shall find none - the unerring instinct with which they will read the slightest signs of the weather, and comprehend the smallest indications of the whereabouts of their game-the readiness with which they will draw conclusions and positive deductions from signs which to others seem light as air-the facility with which they understand their dogs, and their dogs them-and lastly, theis 
wonderful accuracy, rapidity and deliberate promptitude of aim and execution, backed as these are by the great improvements in the art of gunnery, and by the vast superiority of the percussion to the flint lock, are such as would make our ancestors, of a century since, despair amid their admiration-such as constitute the first-rate game shot on the wing, decidedly the greatest marksman and artist with the gun, be the other what he may.

For, without disparaging the beautiful practice of the rifle or pistol, it may be affirmed safely that it is merely mechanical, and attainable by every one possessed of a steady hand and a true eye ; while I know not what of calculation, of intuition, almost of inspiration, is not needed to constitute a crack shot. As my poor friend, Cypress, Jun., said, in one of his inimitably witty false quotations, purporting to be from Pliny's chapter on Black Ducks, "Legere quidem et scribere est poedagogi, sed optimè collineare est Dei," which he rendered somewhat thus, "A creditable scholar can be made by the schoolmaster, but a crack shot is the work of God," the Latinity being equal to the truth of the apopthegm.

Now, without pretending that I can give every person a receipt whereby he can become a "crack shot," which no one, I helieve, can be, unless he is born to that good eminence, or even presuming that I can make him a good sportsman, I shall proceed to set down such facts with regard to the habits and haunts, the seasons and the instincts of game, as I can derive from the best sources, with such directions for the pursuit and killing of them as many years experience has led me to consider the most likely to attain success.

And first of all, we will consider what animals come under the head of upland game, and thence proceed to their generic distinctions and habits, as recorded by our greatest naturalists, after which we shall be led in due season to my own personal experiences and observations.

Our upland game consists then, as we find it here in the northern and north-eastern parts of North America, of three species of grouse proper-one of them very rare and very rarely vot. I. 
killed over dogs—one species of quail-three varieties of waders; several species of duck, and two of hares.

The grouse are, The Pinnated Grouse, Telrao Cupido, commonly known as the Prairie-Hen, or IIealh-Hen.

The Ruffed Grouse, Tetrao Umbellus, vulgarly called the Partridge in New England and New York, and as vulgarly the Pheasant in New Jersey and Southward.

The Canada Grouse, Tetrao Canadensis, commonly known as the Spruce Partridge.

I trust that the remarks I have already made, and the clearly distinctive proofs which I shall hereafter adduce from the best ornithologists, will lead sportsmen to act in earnest about reforming the sporting vocabulary, and eschewing the snobbish and ignorant provincialism, or cockneyism-for such it indeed is, of calling Grouse, "Pheasant and Partridge," and thereby destroying all consistency in the dialect, and all community in the feelings of the sporting world.

The Quail is, The American Quall, Ortyx Virginiana, properly known in New Jersey and eastward as Quail; wrongly to the Southward as Partridge.

The Waders are, The American Woodcock, Scolopax Minor, sive, Microptera Americana-the latter, I conceive, a causeless distinction and subdivision-commonly called in the country, Mud Snipe, Blind Snipe, and Big-headed Snipe; while its correct name, Woodcock, is often given to the larger red-polled Woodpecker.

The American Snipe, Gallinago Wilsonii, commonly known as Eng7ish Snipe.

The Upland Sandpiper, Bartram's Tatler, Tringa Bartramia, sive, Totanus Bartramius, commonly known as the Upland Plover, Grass Plover, or Frost Bird.

The Ducks, which may be classed as Upland game, are TнF. Dusky Duck, Anas Obscura, commonly known as the Black Duck.

The Mallard, Anas Boschas, vulg. Green Head.

The Greev-winged Teal, Anas Carolinensis. 
The Blue-winged Teal, Anas Discors.

The Wood Duck, or Summer Duck, Anas Sponsa.

The Prntail Duck, Anas Acuta, vulg. Sprig Tail, Pigeon 'Tail.

One or two other varieties of this family are common either to both salt and fresh waters, or of so rare occurrence as to require no notice ; of the former I will merely name The SHoveller, Anas Clypeata, and The Golden Eye, Anas Clangula : of the latter, The Gadwald, Anas Strepera.

The Hares are, The Common American Hare, Lepus Americanus, commonly and improperly, Rabbit.

The Northern Hare, Lepus Virginianus, vulgarly and improperly, White Rabbit.

The Common Sora Rail, Rallus Carolinus, must be classed under a sporting head, peculiar to itself-as it is shot from boats, apart froin any other species of game, and in different localities, though in the same manner, with some exceptions, as wild fowl on the coast.

With the exception of the Wild Turkey, which is unquestionably the noblest bird of the order, Rasores, and as such the king of American game, the three Grouse which we possess must take the lead; and first in place, as in size and honor, I assign the palm to

\section{THE PINNATED GROUSE.}

Tetrao Cupido-Linn, Wilson, Audubon. La Gelinotte Huppee d'Amerique-Brissot. The Prairie-Hen, Grouse, or HeathHen.

"Male, 18.27!

"Abundant from Texas, throughout all the Western prairies, to very high up the Missouri, Kentucky, Illinois and Ohio ; almost extirpated in the Middle and Eastern Districts. Resident,

"Adult Male.

"Bill short, robust; upper mandible with the dorsal outline 
curved, the edges overlapping, the tip declinate* and rounded Nostrils basal, roundish, concealed by the feathers. Head small, neck rather long, body bulky. Feet of ordinary length, tarsus short-feathered, toes covered above with numerous short scutella, $\uparrow$ marginate, $\uparrow$ and pectinate, $\S$ hind toe extremely short, two lateral equal, middle toe much longer; claws of ordinary length, strong, arched, rather obtuse, concave beneath.

" Plumage compact, the feathers generally broad and rounded, those of the head and neck narrow, and proportionally shorter, excepting of the crown, which are elongated. Two tufts of lanceolate elongated feathers on the side of the neck, under which is an oblong bare space on either side capable of being inflated. Lower tibial || and tarsalT feathers short, soft and blended. Wings short and curved, the primaries strong and narrow; fourth longest, third and fifth nearly equal, second longer than sixth, first much shorter. Tail very short, much rounded, sloping on both sides, of eighteen broad, rounded feathers.

"Bill dusky, paler beneath; iris brown, toes dull yellow, claws grayish brown; the general color of the upper parts is blackish brown, transversely marked with broad, undulating bands of light yellowish red; the wing coverts and secondaries of a lighter brown, tinged with gray, and barred with paler red, the latter only on the outer webs ; primary quills grayish brown, with black shafts, and spots of pale reddish on the outer webs, excepting toward the end. Tail dark grayish brown, narrowly tipped with dull white, the two middle feathers mottled with brownish red. Space from the bill to the eye, a band from the lower mandible over the cheek and throat, pale yellowish red or cream color; a band of blackish brown under the eye, including the ear coverts, and another about an inch and a half long on

* Declinate-Bent downward.

+ Scutella-Scales overlapping, like tiles or shingles.

$\ddagger$ Marginate-Having margins or borders.

II Pectinate-Toothed, like a comb.

§ Tibial-Belonging to the tibia, or thigh.

T Tarsal-Belonging to the tarsus, or shank. 
the side of the throat. Membrane above the eye scarlet. Bare skin of the sounding bladder orange. The longest feathers of the neck tufts are dark brown on the outer webs, pale yellowish red and margined with dusky on the inner, excepting the lowest, which are all brownish black. The lower parts are marked with large transverse curved bands of grayish brown and pale yellowish gray, the tints deeper on the anterior parts and under the wings. Under tail coverts arranged in three sets, the middle feathers convex, involute, white, with two concealed brown spots; the lateral larger, of the same form, abrupt, variegated with dusky red and white, the extremity of the latter color, but with a very narrow terminal margin of black. The tibial and tarsal feathers are gray, obscurely and minutely banded with yellowish brown.

"Length 18 inches; extent of wings, $27 \frac{1}{2}$; bill along the back, $\frac{7}{1^{2}}$; along the edge, $\frac{11}{12}$; tarsus, $1 \frac{1}{2}$; weight, $1 \mathrm{lb} .13 \mathrm{oz}$.

"Adult female.

"The female is considerably smaller than the male, and wants the crest, neck-tufts and air-bags, but in other respects resembles him."-Audubon's Birds of America.

Attagen Americana, Brissot, 1, p. 59-Pinnated Heath-Cock, Bonnasa Cupido, Steph. Sh. cont. 11, p. 299-Tetrao Cupido, Bonap. Synop, p. 126.

"Before I enter on a detail of the observations which I have myself personally made on this singular species, I shall lay before the reader a comprehensive and very circumstantial memoir on the subject, communicated to me by the writer, Dr. Samuel L. Mitchill, of New York, whose exertions both in his public and private capacity, in behalf of science, and in elucidating the natural history of his country, are well known and highly honorable to his distinguished situation and abilities. That peculiar tract, generally known by the name of the Brushy Plains of Long Island, having been from time immemorial the resort of the bird now before us, some account of this particular range of country seemed necessarily connected with the subject, and has accordingly been obligingly attended to by the learned Professor : 
66 New YoRk, SeP'r. 19, 1810.

"6 Dear Sir,-It gives me much pleasure to reply to your letter of the 12th inst., asking of me information concerning the Grouse of Long Island.

"6 6 The birds, which are known there emphatically by the name of Grouse, inhabit chiefly the forest range. This district of the island may be estimated as being between forty and fifty miles in length, extending from Bethphage, in Queen's County, to the neighborhood of the Court-house, in Suffolk. Its breadth is not more than six or seven. For though the island is bounded by the Sound, separating it from Connecticut on the north and the Atlantic Ocean on the south, there is a margin of several miles on each side in the actual possession of human beings.

" ' The regions in which these birds reside lie mostly within the towns of Oysterbay, Huntington, Islip, Smithstown and Brooklyn; though it would be incorrect to say that they were not to be met with sometimes in River Head and Southampton. This territory has been defined by some sportsmen as situated between Hempstead Plain on the west and Shinnecock Plain on the east.

" " The more popular name for them is Heath-Hens. By this they are designated in the act of our Legislature for the preservation of them and of other game. I well remember the passing of this law. The bill was introduced by Cornelius J. Bogart, Esq., a Member of Assembly from the city of New York. It was in the month of February, 1791, the year when, as a representative from my native county of Queen's, I sat for the first time in Legislature.

" " The statute declares among other things, that " the person who shall kill any Heath-Hen within the counties of Suffolk or Queen's, between the 1st day of April and the 5th day of October, shall for any such offence forfeit and pay the sum of two dollars and a half, to be recovered with costs of suit by any person who shall prosecute for the same before any Justice of the Peace in either of said counties, the one half to be paid to plaintiff and the other half to the overseers of the poor ; and if any Heath-Hen so killed shall be found in the possession of any per- 
son, he shall be deemed guilty of the offence and suffer the penalty. But it is provided that no defendant shall be convicted unless the action shall be brought within three months after the violation of the law."

" "The country selected by these exquisite birds requires a more particular description. You already understand it to be the midland and interior district of the island. The soil of this island is, generally speaking, a sandy or gravelly loam. In the parts less adapted to tillage, it is more of an unmixed sand. This is so much the case, that the shore of the beaches beaten by the ocean affords a material from which glass has been prepared. Silicious grains and particles predominate in the region chosen by the Heath-Hens or Grouse; and here there are no rocks, and very few stones of any kind. This sandy tract appears to be a dereliction of the ocean, but is nevertheless not doomed to total sterility. Many thousand acres have been reclaimed from the wild state and rendered very productive to man; and within the towns frequented by these birds, there are numerous inhabitants, and among them some of our most wealthy farmers. But within the same limits there are also tracts of great extent, where men have no settlements, and others where the population is spare and scanty. These are, however, by no means naked deserts; they are, on the contrary, covered with trees, shrubs and smaller plants. The trees are mostly pitch-pine, of inferior size, and white-oaks of a small growth. They are of a quality very fit for burning. Thousands of cords of both sorts of fire-wood are annually exported from these barrens. Vast quantities are occasionally destroyed by the fires which, through carelessness or accident, spread far and wide through the woods. The city of New York will probably for ages derive fuel from these grounds. The land, after being well cleared, yields to the cultivator poor crops. Unless, therefore, he can help it by manure, the best disposition is to let it grow up to forest again.

"6 ' Experience has proved that in a term of forty or fifty years, the new growth of timber will be fit for the axe. Hence it may 
be perceived that the reproduction of trees, and the protection they afford to Heath-Hens, would be perpetual, or in other words, not circumscribed by any calculable time, provided the persecutors of the latter would be quiet. Beneath these trees grow more dwarfish oaks, overspreading the surface, sometimes with here and there a shrub, and sometimes a thicket. These latter are from about two to ten feet in height. When they are the principal product, they are called, in common conversation, brush, as the flats on which they grow are termed brushy plains. Among this hardy shrubbery may frequently be seen the creeping vegetable, named partridge-berry, covering the sand with its lasting verdure.

" 'In many spots the plant which produces hurtleberries sprouts up among the other natives of the soil. These are the more important; though I ought to inform you, that the hills reaching from east to west and forming the spine of the island, support kalmias, hickories, and many other species; that I have seen azalias and andromedas, as I passed through the wilderness, and that where there is water, cranberries, alders, beeches, maples, and other lovers of moisture, take their stations. This region, situated thus between the more thickly inhabited strips or belts on the north and south sides of the island, is much travelled by waggons, and intersected accordingly by a great number of paths.

" " As to the birds themselves, the information I possess scarcely amounts to an entire history. You who know the difficulty of collecting facts, will be most ready to excuse my deficiencies. The information I give you is such as I rely on. For the purpose of gathering the materials, I have repeatedly visited their haunts. I have likewise conversed with several men who were brought up at the precincts of the Grouse ground, who had been witnesses of their habits and manners, who were accustomed to shoot them for the market, and who have acted as guides for gentlemen who go the: e for sport.

« ' Bulk.-An adult Grouse, when fat, weighs as much as a barn-door fowl of moderate size, or about three pounds avoirdu- 
poise. But the eagerness of the sportsmen is so great, that a large proportion of those they kill are but a few months old, and have not attained their complete growth. Notwithstanding the protection of the law, it is very common to disregard it. The retired nature of the situation favors this. It is well understood that an arrangement can be made which will blind and silence informers, and the gun is fired with impunity for weeks before the time prescribed in the act. To prevent this unfair and unlawful practice, an association was formed a few years ago, under the title of the 'Brush Club,' with the express and avowed intention of enforcing the game law. Little benefit, however, has resulted from its laudable exertions; and, under a conviction that it was impossible to keep poachers away, the society declined.

" "At present the statute may be considered as operating very little towards their preservation. Grouse, especially full-grown ones, are becoming less frequent. Their numbers are gradually diminishing; and, assailed as they are on all sides, almost without cessation, their scarcity may be viewed as foreboding their eventual extermination.

" ' Price.-Twenty years ago, a brace of Grouse could be bought for a dollar. They cost now from three to five dollars. A handsome pair seldom sells in the New York market now-a-days for less than thirty shillings-three dollars and seventy-five cents-nor for more than forty, five dollars.

" "These prices indicate, indeed, the depreciation of money and the luxury of eating. They prove at the same time that Grouse are become rare ; and this fact is admitted by every man who seeks them, whether for pleasure or profit.

" ' Amours.-The season for pairing is in March, and the breeding time is continued through April and May. Then the male Grouse distinguishes himself by a peculiar sound. When he utters it, the parts about the throat are sensibly inflated and swelled. It may be heard on a still morning for three or more miles; some say they have perceived it as far as five or six. This noise is a sort of ventriloquism. It does not strike the ear 
of the bystander with much force, but impresses him with the idea, though produced within a few rods of him, of a voice a mile or two distant. This note is highly characteristic. Though very peculiar, it is termed tooting, from its resemblance to the blowing of a conch as heard from a remote quarter.

" " The female makes her nest on the ground, in recesses very rarely discovered by man. She usually lays from ten to twelve eggs. Their color is of a brownish yellow, much resembling those of a Guinea-Hen. When hatched, the brood is protected by her alone. Surrounded by her young, the mother bird much resembles a domestic Hen and Chickens. She frequently leads them to feed in the roads crossing the woods, on the remains of maize and oats contained in the dung dropped by the travelling horses. In that employment they are often surprised by the passengers. On that occasion the dam utters a cry of alarm. The little ones immediately scamper to the brush, and while they are skulking into places of safety, their anxious parent beguiles the spectator by drooping and fluttering her wings, limping along the path, rolling over in the dirt, and other pretences of inability to walk or fly.

" ' Food.-A favorite article of their diet is the Heath-Hen plum or partridge-berry, beforementioned; they also use hurtleberries or cranberries. Worms and insects of several kinds are occasionally found in their crops. But in the winter they subsist chiefly on acorns and the buds of trees which have shed their leaves. In their stomachs have been sometimes observed the leaves of a plant supposed to be a winter-green; and it is said when they are much pinched, they betake themselves to the buds of the pine. In convenient places they have been known to enter cleared fields and regale themselves on the leaves of clover, and old gunners have reported that they have been known to trespass upon patches of buckwheat and peck up the grains.

" "Migration.-They are stationary, and are never known to quit their abode. There are no facts showing in them any disposition to migration. On frosty mornings, and during snow, they perch on the upper branches of pine trees. They avoid wet 
and swampy places, and are remarkably attached to dry ground. The low and open brush is preferred to high and shrubby thickets. Into these latter places they fly for refuge, when closely pressed by the hunters; and here, under a stiff and impenetrable cover, they escape the pursuit of dogs and men. Water is so seldom met with on the true Grouse-ground, that it is necessary to carry it along for the pointers to drink. The flights of Grouse are short, but sudden, rapid and whirring. I have not heard of any success in taming them. They seem to resist all attempts at domestication In this, as well as in many other respects, they resemble the Quail of New York, or the Partridge of Pennsylvania

" 'Manners.-During the period of mating, and while the females are occupied in incubation, the males have a practice of assembling principally by themselves. To some select and central spot, where there is very little underwood, they repair from the adjoining district. From the exercises performed there, this is called a scratching-place. The time of meeting is the break of day. As soon as the light appears, the company assembles from every side, sometimes to the number of forty or fifty. When the dawn is passed, the ceremony begins by a low tooting from one of the cocks. This is answered by another. They then come forth, one by one, from the bushes, and strut about with all the pride and ostentation they can display. Their necks are incurvated, the feathers on them are erected into a sort of ruff; the plumes of the tails are expanded like fans; they strut about in a style resembling, as nearly as small may be illustrated by great, the pomp of the Turkey-Cock. They seem to vie with each other in stateliness, and, as they pass each other, frequently cast looks of insult and utter notes of defiance. These are the signals for battles. They engage with wonderful spirit and fierceness. During these contests, they leap a foot or two from the ground, and utter a cackling, screaming and discordant cry. They have been found in these places of resort even earlier than the appearance of light in the east. This fact leads to the belief, that a part of them assemble over night. The rest join them 
in the morning. This leads to the farther belief that they roost on the ground; and the opinion is confirmed by the discovery of little rings of dung, apparently deposited by a flock which had passed the night together. After the appearance of the sun, they disperse. These places of exhibition have been often discovered by the hunters, and a fatal discovery it has been for poor Grouse.

" 'The destroyers construct for themselves lurking-holes made of pine branches, called bough-houses, within a few yards of the parade, and hither they repair with their fowling-pieces, in the latter part of the night, and wait the appearance of the birds. Waiting the moment when two are proudly eyeing each other, or engaged in battle, or when a greater number can be seen in a range, they pour on them a destructive charge of shot. This annoyance has been given in so many places, and to such an extent, that the Grouse, after having been repeatedly disturbed, are afraid to assemble. On approaching the spot to which their instinct prompts them, they perch on the neighboring trees, instead of alighting at the scratching-place; and it remains to be observed how far the restless and tormenting spirit of the marksman may alter the nature and habits of the Grouse, and oblige them to new ways of life. They commonly keep together, in coveys or packs, as the phrase is, until the pairing season. A full pack consists, of course, of ten or a dozen. Two packs have been known to associate. I lately heard of one whose number amounted to twenty-two. They are so unapt to be startled, that a hunter, assisted by a dog, has been able to shoot almost a whole pack, without making any of them take wing. In like manner, the men lying in concealment near the scratching-places, have been known to discharge several guns before either the report of the explosion or the sight of their wounded or dead fellows would rouse them to flight. It has been farther remarked that when a company of sportsmen have surrounded a pack of Grouse, the birds seldom or never rise upon their pinions while they are encircled; but each runs along until it passes the person that is nearest, and then flutters off with the 
ntmost expedition. As you have made no enquiry of me concerning the ornithological character of these birds, I have not mentioned it, premising that you are already perfectly acquainted with their classification and description. In a short memoir, written in 1803, and printed in the eighth volume of the Medica Repository, I ventured an opinion as to the genus and species. Whether I was correct is a technical matter, which I leave you to adjust. I am well aware that European accounts of our productions are often erroneous, and require revision and amendment. This you must perform. For me it remains to repeat my joy at the opportunity your invitation has afforded me to contribute somewhat to your elegant work, and at the same time to assure you of my earnest hope that you may be favored with ainple means to complete it.

\section{" "Samuel L. Mitchill." "}

"Duly sensible of the honor of the foregoing communication, and grateful for the good wishes with which it is concluded, I shall now, in further elucidation of the subject, subjoin a few particulars, properly belonging to my own department.

"It is somewhat extraordinary that the European naturalists, in their various accounts of our different species of Grouse, should have said little or nothing of the one now before us, which in its voice, manners, and peculiarity of plumage, is the most singular, and in its flesh the most excellent of all those of its tribe, that inhabit the territory of the United States. It seems to have escaped Catesby, during his residence and different tours through this country, and it was not till more than twenty years after his return to England, viz., 1743, that he first saw some of these birds, as he informs us, at Cheswick, the seat of the Earl of Wilmington. His lordship said they came from America; but from what particular part could not tell. Buffon has confounded it with the Ruffed Grouse, the Connon Partridge of New England, or Pheasant of Pennsylvania, (Tetrao Umbellus.) Edwards and Pennant have, however, discovered that it is a different species, but have said little of its note, of its flesh or 
peculiarities ; for alas, there was neither voice or action, nor delicacy of flavor in the shrunk and decayed skin from which the former took his figure and the latter his description; and to this circumstance must be attributed the barrenness and defects of both. This rare bird, though an inhabitant of different and very distant districts of North America, is extremely particular in selecting his place of residence, pitching only upon those tracts whose features and productions correspond with his mode of life, and avoiding immense intermediate regions that he never visits. Open, dry places, thinly interspersed with trees, or partially overgrown with shrub-oak, are his favorite haunts. Accordingly, we find these birds on the Grouse-plains of New Jersey, in Burlington County, as well as on the brushy plains of Long Island; among the trees and shrub-oaks of Pocano, in Northampton County, in Pennsylvania ; over the whole extent of the barrens of Kentucky, on the luxuriant plains and prairies of the Indiana and Upper Louisiana, and according to the information of the late Governor Lewis, on the vast remote plains of the Columbia River, in all these places preserving the same singular habits. Their predilection for such situations will be best accounted for by considering the following facts and circumstances :-First, their mode of flight is generally direct and laborious-ill calculated for the labyrinth of a high and thick forest, crowded and intersected with trunks and arms of trees that require continual angular evolution of wing or sudden turnings, to which they are by no means accustomed. I have always observed them to avoid the high-timbered groves that occur here and the: $\mathrm{e}$ in the Barrens. Connected with this fact is a circumstance related to me by a very respectable inhabitant of that countyviz., that one forenoon a Cock-Grouse struck the stone chimney of his house with such force, as instantly to fall dead to the ground. Secondly, their known dislike of ponds, marshes, or watery places, which they avoid, drinking but seldom, and it is believed never from such places. Even in confinement this peculiarily has been taken notice of. While I was in the State of Tennessee, a person, living within a few miles of Nashville, 
had caught an old Hen-Grouse in a trap, and being obliged to keep her in a large cage, she struck and abused the rest of the poultry, he remarked that she never drank, and that she even avoided that quarter of the cage where the cup containing the water was placed. Happening one day to let some water fall on the cage, it trickled down in drops along the bars, which the bird no sooner observed than she eagerly picked them off, drop by drop, with a dexterity that showed she had been habituated to this mode of quenching her thirst, and probably to this mode only, in those dry and barren tracts, where, except the drops of dew and drops of rain, water is very rarely to be met with. For the space of a week he watched her closely, to discover whether she still refused to drink; but, though she was constantly fed on INDIAN corn, the cup and water still remained untouched and untasted. Yet, no sooner did he again sprinkle water on the bars of the cage, than she eagerly and rapidly picked them off, as before. The last and probably the strongest inducement to their preferring these places, is the small acorn of the shruboak, the strawberries, huckleberries and partridge-berries, with which they abound, and which constitute the principal part of the food of these birds. These brushy thickets also afford them excellent shelter, being almost impenetrable to dogs or birds of prey. In all those places where they inhabit, they are, in the strictest sense of the word, resident; having their particular haunts and places of rendezvous-as described in the preceding account-to which they are strongly attached. Yet they have been known to abandon an entire tract of such country, when, from whatever cause it might proceed, it became again covered with forest. A few miles south of the town of York, in Pennsylvania, commences an extent of country fairly of the character described, now chiefly covered with wood, but still retaining the name of Barrens. In the recollection of an old man, born in that part of the country, this tract abounded with Grouse. The timber growing up, in progress of years, these birds totally disappeared, and for a long period of time he had seen none of them, until, migrating with his family to Kentucky, on entering 
the BARRENs, he one morning recognized the well-known music of his old acquaintances, the Grouse, which, he assures me, are the very same with those he had known in Pennsylvania. But, what appeared to me the most remarkable circumstance relative to this bird, is, that none of all those writers who have attempted its history, have taken the least notice of those two extraordinary bags of yellow skin, which mark the neck of the male, and which constitute so striking a peculiarity. These appear to be formed by an expansion of the gullet, as well as of the exterior skin of the neck, which, when the bird is at rest, hangs in loose, pendulous wrinkled folds along the side of the neck, the supplemental wings, at the same time, as well as when the bird is flying, lying along the neck. But when these bags are inflated with air, in breeding-time, they are equal in size, and very inuch resemble in color a middle-sized, fully-ripe orange. By means of this curious apparatus, which is very observable several hundred yards off, he is enabled to produce the extraordinary sound mentioned above, which though it may easily be imitated, is yet difficult to describe by words. It consists of three notes of the same tone, resembling those produced by the NightHawks, in their rapid descent, each strongly accented, the latter being twice as long as the others. When several are thus engaged, the ear is unable to distinguish the regularity of those triple notes, there being at such times one continued humming, which is disagreeable and perplexing, from the impossibility of ascertaining from what distance or quarter it proceeds. While uttering this, the bird exhibits all the ostentatious gesticulations of a TURKEY-Cock, erecting and fluttering his neck-wings, wheeling and passing before the female, and close before his fellows, as in defiance. Now and then are heard some rapid, cackling notes, not unlike that of a person tickled to excessive laughter ; and, in short, one can scarcely listen to them without feeling disposed to laugh from sympathy. These are uttered by the the males, while engaged in fight, on which occasion they leap up against each other, exactly in the manner of T'URKIES, seemngly with more malice than effect. This humining continues 
from a little before day-break to eight or nine o'clock in the morning, when the parties separate to seek for food.

"Fresh-ploughed fields in the vicinity of their resorts are sure to be visited by these birds, every morning, and frequently also in the evening. On one of these I counted, at one time, seventeen males, most of whom were in the attitude represented, making such a continued sound as, I am persuaded, might have been heard more than a mile off. The people of the Barrens informed me that when the weather becomes severe, with snow, they approach the barn and farm-house, and are sometimes seen sitting on the fields in the Indian corn, seeming almost domesticated. At such times great numbers are taken in traps. No pains, however, on regular plans, have ever been persisted in, as far as I was informed, to domesticate these delicious birds. A Mr. Reid, who lives between the PilotKNoBs and Bairdstown, told me that, a few years ago, one of his sons found a Grouse's nest, with fifteen eggs, which he brought home and immediately placed beneath a hen then sitting, taking away her own. The nest of the Grouse was on the ground, under a tussock of long grass, formed with very little art and few materials. The eggs were brownish white, and about the size of a pullet's. In three or four days, the whole were hatched. Instead of following the Hev, they compelled her to move after them, distracting her with the extent and di versity of their wanderings ; and it was a day or two before they seemed to understand her language, or consent to be guided by her. They were let out to the fields, where they paid little regard to their nurse, and, in a few days, only three of them remained. These became exceedingly tame and familiar, were most expert fly-catchers, but soon after they also disappeared.

"On dissecting these birds, the gizzard was found extremely muscular, having almost the hardness of a stone; the heart remarkably large; the crop was filled with briar-knots; containing the larvæ of some insect, quantities of a species of green lichen, small, hard seeds, and some grains of Indian Corn." -Wilson's Am. Ornith. 
Next to this fine bird, both in his game qualities and the excellence of his flesh, I note, unhesitatingly,

\section{THE RUFFE GROUSE.}

Tetrao Umbellus. Linn: Wilson: Audubon. La Gelinotte Huppeè de Pennsylvanie. Brissot.—The Pheasant, or Partridge.

"Male, 18.24.

"Common from Maryland to Labrador, and, in the interior, from the mountainous districts to Canada and the Jashatchẹwan, Columbian River. Resident.

"Adult Male.

"Bill short, robust, slightly arched, rather obtuse; the base covered by feathers; upper mandible, with the dorsal outline, straight in the feathered part, convex toward the end, the edges overlapping, the tip declinate; under mandible somewhat bulging toward the tip ; the sides convex. Nostrils concealed among the feathers. Head and neck small. Body bulky. Feet of ordinary length. Shank feathered, excepting at the lower part in front, where it is scutellate, spurless ; toes scutellate above, pectinate on the sides; claws arched, depressed, obtuse.

"Plumage compact, glossy. Feathers of head narrow, and elongated into a curved tuft. A large space on the neck destitute of feathers, but covered by an erectile ruff of elongated feathers, of which the upper are silky, shining, and curved forward at the end, which is very broad and rounded. Wings short, broad, curved, and much rounded. Tail long, ample, rounded, of eighteen feathers.

"Bill brown color, brownish-black to ward the tip. Iris hazel. Feet yellowish-gray. Upper part of the head and wing part of the neck bright yellowish-red. Back rich chesnut, marked with oblong white spots, margined with black.

"Tail reddish-yellow, barred and minutely mottled with black, and terminated by a broad band of the latter color, between two narrow bands of bluish-white, of which the one is terminal. A 
yellowish band from the upper mandible to the eye, beyond which it is prolonged. Throat and lower part of the neck light brownish-yellow. Lower ruff feathers of the same color, barred with reddish-brown; the upper black, with blue reflections. A tuft of light chesnut feathers under the wings. The rest of the under parts yellowish-white, with broad, transverse spots of brownish-red; the abdomen yellowish-red; and the under tail coverts mottled with brown.

"Length, 18 inches; extent of wings, 2 feet; bill, along the ridge, ${ }_{4}^{3}$; along the gap, $1 \frac{1}{12}$; shank, $1 \frac{7}{12}$; middle toe, $1_{4}^{3}$.

" Adult female.

"The plumage of the female is less developed, and inferior in beauty. The feathers of the head and ruff are less elongated; the latter of a dull black. The tints of the plumage generally are lighter than in the male.

"The eggs usually measure an inch and a half in length, by an inch and two-twelfths in breadth, and are of an uniform dull yellowish tint."-Audubon's Birds of America.

"This is the Partridge of the Eastern States, and the Pheasant of Pennsylvania and the Southern Districts. It is represented as it was faithfully copied from a perfect and very beautiful specimen. This elegant species is well known in almost every quarter of the United States, and appears to inhabit a very extensive range of country. It is common at Moose Fort, on Hudson's Bay, in lat. $51^{\circ}$, is frequent in the upper parts of Georgia, very abundant in Kentucky, and the Indiana Territory, and was found by Capts. Lewis and Clark in crossing the great range of mountains that divide the waters of the Columbia and Missouri more than three thousand miles, by the measurement, from the mouth of the latter. Its favorite places of resort are high mountains, covered with the balsam, pine, hemlock, and other evergreens. Unlike the Pinnated Grouse, it always prefers the woods, is seldom or never found in open plains, but loves the pine-sheltered declivities of mountains near streams of water. 
' This great difference of disposition in two species whose food seems to be nearly the same, is very extraordinary. In those open plains called the Barrens, in Kentucky, the Pinnated Grouse was seen in great numbers, but none of the Rufred. While in the high groves with which this singular tract of country is interspersed, the latter, or Pheasant, was frequently met with, but not a single individual of the former. The native haunts of the Pheasant, being a cold, high, mountainous, and woody country, it is natural to expect that as we descend from thence to the sea shores, and the low, flat, and warm climate of the Southern States, these birds should become more rare, and such is indeed the case. In the low parts of Carolina, and Georgia, and Florida, they are very seldom observed, but as we advance inland to the mountains, they again make their appearance. In the low parts of NEw JERSEY we indeed occasionally meet with them, but this is owing to the more northerly situation of the country, for even here they are far less numerous than among the mountains. Dr. Burton, and several other English writers, have spoken of a Long-TAILED Grouse, said to inhabit the back parts of Virginia, which can be no other than the present species; there being, as far as I am acquainted, only these two, ${ }^{*}$ the Ruffed and Pinnated Grouse, found natives within the United States. The manners of the Pheasant are solitary, they are seldom found in coveys of more than four or five together, and more usually in pairs, or singly. They leave their sequestered haunts in the woods early in the morning, and seek the path or road to pick up gravel, and glean among the droppings of the horses. In travelling among the mountains that bound the Susquehanna, I was always able to furnish myself with an abundant supply of these birds without leaving the path. If the weather be foggy or lowering, they are sure to be seen in such situations. They generally move along with great stateliness, the broad, fan-like tail spread out.

" The drumming, as it is usually called, of the Pheasant, is another singularity of this species. This is performed by the

* This is, of course, an error of Wilson's. 
male alone. In walking through the solitary woods frequented by these birds, a stranger is surprised by suddenly hearing a kind of thumping, very similar to that produced by striking two full-blown ox-bladders together, but much louder; the strokes at first are slow and distinct, but gradually increase in rapidity, till they run into each other : resembling the rumbling sound of very distant thunder dying away gradually on the ear. After a few minutes' pause, this is again repeated, and in a calm day may be heard nearly a mile off. This drumming is most common in spring, and is the call of the cock to a favorite female. It is produced in the following manner: The bird, standing on an old prostrate $\log$, generally in a retired and sheltered situation, lowers his wings, erects his expanded tail, contracts his throat, elevates the two tufts of feathers on the neck, and inflates his whole body something in the manner of a Turkeycock, strutting and wheeling about in great stateliness. After a few manœuvres of this kind he begins to strike with his stiffened wings in short and quick strokes, which become more and more rapid until they run into each other, as has been already described. This is most common in the morning and evening, though I have heard them drumining at all hours of the day. By means of this, the gunner is led to his retreat, though to those unacquainted with the sound there is great deception in the supposed distance, it generally appearing to be much nearer than it really is. The Pheasant* begins to pair in ApriL, and builds its nest early in $\mathrm{M}_{\mathrm{AY}}$. This is placed on the ground at the root of a bush, old log, or other sheltered or solitary situation, well-surrounded with withered leaves. Unlike that of the QuAIL, it is open above, and is usually composed of dry leaves and grass. The eggs are from nine to fifteen in number, of brownish-white, without any spots, and nearly as large as those of a Pullet. The young leave the nest as soon as hatched, and are directed by the cluck of the mother, very much in the manner of the common Hen. On being surprised, she exhibits all the distress and affectionate manœuvres of the Quail, and most other birds, to lead yo's

* An error! The Ruffed Grouse is polygamous, and does not pair at all. 
away from the spot. I once started a Hen Pheasant with a single young one, seemingly only a few days old; there might have been more, but I observed only this orre. The mother fluttered before me for a moment, but suddenly darted towards the young one, seized it in her bill, and flew off along the surface through the woods with great steadiness and rapidity, till she was beyond my sight, leaving me in great surprise at the incident. I made a very close and active search around the spot for the rest, but without success. Here was a striking instance of something more than what is termed blind instinct, in this remarkable deviation from her usual manœuvres when she has a numerous brood. It would have been impossible for me to have injured the affectionate mother who had exhibited such an example of presence of mind, reason, and sound judgment as must have convinced the most bigoted advocate of mere instinct. To carry off a whole brood in this manner at once, would have been impossible, and to attempt to save one at the expense of the the rest, would be unnatural. She, therefore, usually takes the only possible mode of saving them in that case, by decoying the person in pursuit of herself, by such a natural imitation of lameness as to impose on most people. But here, in the case of a single, solitary young one, she instantly altered her plan, and adopted the most simple and effectual means for its preservation. The Pheasant usually springs within a few yards, with a loud whirring noise, and flies with great vigor through the woods, beyond reach of view, before it alights. With a good dog, however, they are easily found, and at some times exhibit a singular degree of infatuation, by looking down from the branches where they sit, on the dog below, who, the more noise he keeps up, seems the more to confuse and stupify them, so that they may be shot down one by one till the whole are killed, without attempting to fly off. In such cases, those on the lower limbs must be taken first; for should the upper be first killed, in their fall they alarm those below, who immediately fly off. In deep snows they are usually taken in traps, commonly dead traps, supported by a figure 4 trigger. At this season, when suddenly 
alarmed, they frequently dive into the snow, particularly when it has newly fallen, and coming out at a considerable distance, again take wing. They are pretty hard to kill, and will often carry off a large load to the distance of two hundred yards, and drop down dead. Sometimes in the depth of winter they approach the farm-house, and lurk near the barn or about the garden. They have, also, been often taken young, and tamed, so as to associate with the fowls; and their eggs have frequently been hatched under the common Hen, but these rarely survive until full grown. They are exceedingly fond of the seeds of grapes, occasionally eat ants, chesnuts, blackberries, and various vegetables. Formerly they were numerous in the immediate vicinity of Philadelphia, but as the woods were cleared, and population increased, they retreated to the interior. At present there are very few to be found within several miles of the city, and those only singly in the most solitary and retired woody recesses. The Pheasant is in best order for the table in September and October. At this season they feed chiefly on wortleberries, and the little aromatic partridgeberries, the last of which give the flesh a peculiar delicate flavor. With the former, our mountains are literally covered from August to November, and these constitute at that season, the greater part of their food. During the deep snows of winter they have recourse to the buds of alder, and the tender buds of laurel. I have frequently found their crops distended with a large handful of these latter alone, and it has been confidently asserted that after being fed for some time on the laurel buds, the flesh becomes highly dangerous to eat of, partaking of the poisonous qualities of the plant. The same has been asserted of the flesh of the deer, when, in severe weather and deep snows they subsist on the leaves and bark of the laurel. Though I have myself ate freely of the flesh of the Pheasant, after emptying it of large quantities of laurel buds, without experiencing any bad consequences; yet from the respectability of those, some of them eminent physicians, who have particularized cases in which it has proved deleterious and even fatal, I am inclined to believe in certain cases, wrere this 
kind of food has been long continued, and the birds allowed to remain undrawn for several days, until the contents of the crop and stomach have had time to diffuse themselves through the flesh, as is too often the case, it may be unwholesome, and even dangerous. Great numbers of these birds are brought to our markets at all times during fall and winter, some of which are brought from a distance of more than a hundred miles, and have been probably dead a week or two, unpicked and undrawn, before they are purchased for the table.

"Regulations prohibiting them from being brought to market, unless picked and drawn, would very probably be a sufficient security against all danger. At these inclement seasons, however, they are lean and dry, and, indeed, at all times, their flesh is far inferior to that of the Pinnated Grouse. They are usually sold in Philadelphia market at from three-quarters of a dollar to a dollar and a quarter a pair,-sometimes higher."-Wilson's Am. Ornith.

The last of this species which it is worth our while to notice as a sporting bird, is the Canada Grouse, and even it, although Mr. Audubon speaks of it as abundant in parts of Maine, and although it unquestionably exists in the north-eastern angle of New York, is so rarely met, and so shy, as to be known to very few of our sportsmen.

The Willow Grouse, or Willow Ptarmigan, perhaps the most beautiful of all the American species, and perhaps to be met with in the extreme north of Maine, is too uncommon to be classed as game. I fear, indeed, that few of my readers will ever have the good fortune to kill the beautiful little Grouse of which we are now speaking. I doubt whether it would ever lie to dogs. It is a solitary forest bird. 


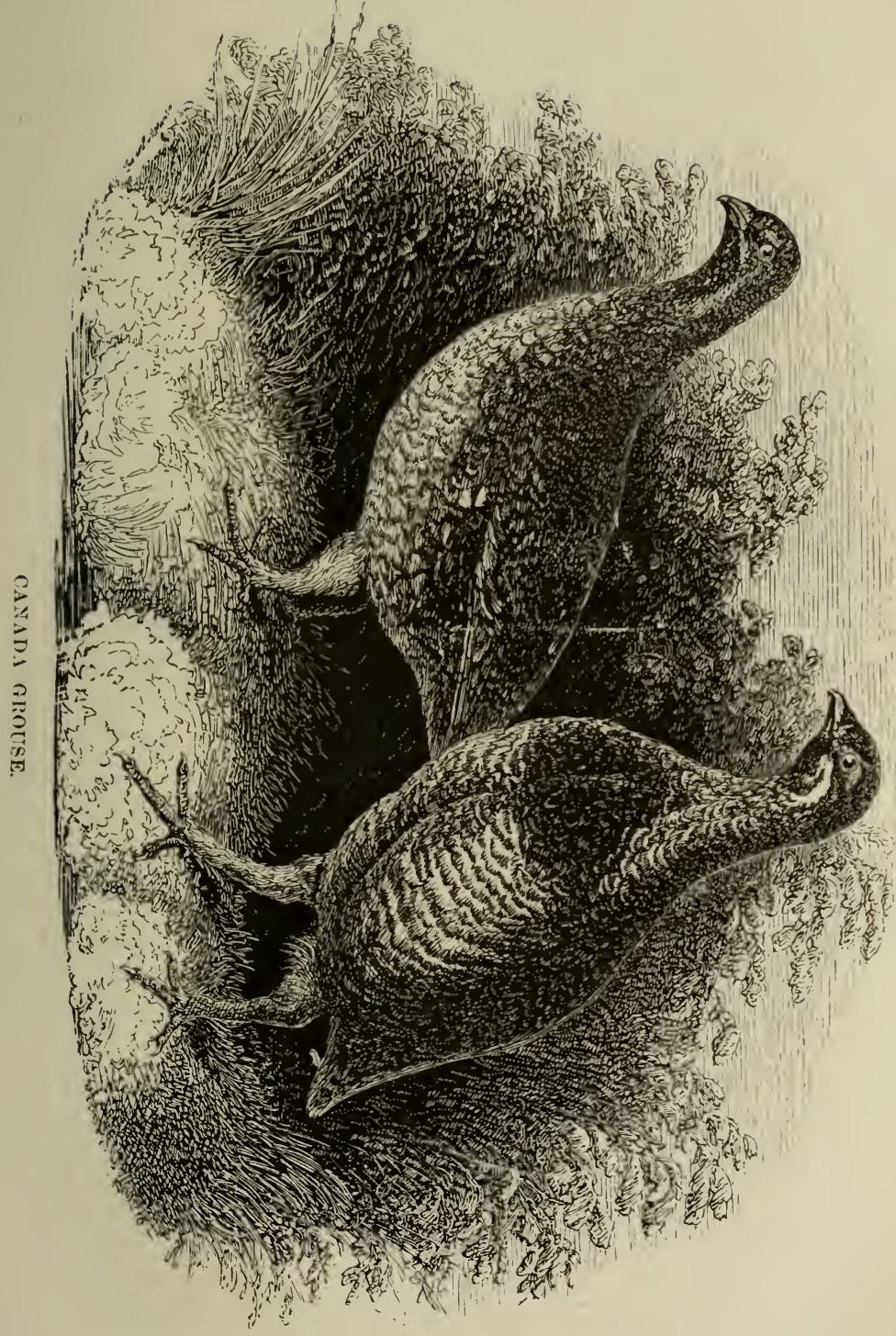



THE CANADA GROUSE.

Tetrao Canadensis. Linn: Bonaparte: Audubon. Spotled Grouse; Franklin's Grouse; Spruce Partridge.

" Male, 15 $5_{4}^{3} .21_{4}^{3}$. Female, $15_{2}^{1} .21$.

" Plentiful from the Northern parts of New York to Labrador, as well as from Canada to the Arctic Sea, Columbia River. Partially migratory in winter.

"Adult Male.

" Bill short, robust, slightly arched, rather obtuse; the base covered by feathers; upper mandible with the dorsal outline convex toward the end-the edges sharp and overhanging-the tip declinate; lower mandible slightly convex in its dorsal outline; the back broad and rounded; the sides sloping outward; the tip rather rounded. Nostrils basal, lateral, concealed by the short feathers. Head small; neck of ordinary length; body full. Feet short, rather small; tarsus short, roundish, feathered. Toes scutellate above, broadly margined and pectinate; the anterior ones connected by a web at the base; the hind toe very small, the two lateral about equal, the middle one much longer; claws short, arched, compressed, rather obtuse.

"Plumage compact, slightly glossed. Feathers of the head very short. Wings short, broad, much rounded and curved, the third quill longest, the fourth next, the second and fifth nearly equal, the first very short. Tail ample, of ordinary length, rounded, of sixteen broad rotundate truncate* feathers, having a minute mucio.

"Bill and claws brownish black. Iris $\nmid$ hazle. Fringed membrane over the eyes, vermillion. Toes purplish gray. Upper plumage and flanks brownish black, transversely barred with brownish gray; the tip of each feather with two bars of the latter color; on the hind parts the bars are larger, and the pale

* Truncate-Cut off short and abruptly.

+ Iris-The circle about the pupil of the eye. 
ones more tinged with brown. Quills and larger coverts, blackish brown, the outer edges of the primaries pale brownish gı ay, and those of the secondaries minutely mottled with the same. Tail coverts brownish black, minutely mottled and tipped with grayish white; tail feathers darker, and tipped with dull brownish red. Lower parts black, the feathers on the throat having a white spot near the end; those of the lower and lateral parts of the neck unspotted; of the breast, with a broad, subterminal spot, and the under tail coverts largely tipped with white. Inner wing coverts above brown, the proximal and axillaries tipped with white.

"Length, $15 \frac{3}{4}$ inches; extent of wings, $21 \frac{3}{4}$; bill, along the back, $\frac{8}{12}$; along the edge, $1 \frac{2}{12}$; tarsus, $1 \frac{1}{4}$; weight, $17 \mathrm{oz}$.

" Adult female.

"The female is not much smaller. The superciliary membrane is much less, but of the same color. The upper parts are nearly of the same tints, but more broadly barred; the head, sides of the neck, fore neck, and anterior parts of the breast, yellowish gray, barred with brownish black; the lower parts, grayish black, barred with reddish white. The tail is minutely tipped and mottled with brownish red. The younger females have more of the yellowish red tints than the old ones. In other respects, the coloring is nearly similar.

"Length, $15_{2}^{1}$ inches; extent of wings, 21 ; weight, 15oz."Audubon.

Inasmuch as this rare and beautiful little species of Grouse is almost entirely unknown to our sportsmen, as I have never found any who have killed it, and very few who are aware of its existence; and as, with a single exception, I have never but once shot it, though I have on several occasions tried for it in the State of Maine, on the waters of the Penobscot, I cannot speak as to its habits or haunts with any certainty, from my own personal experience, or from the report of sportsmen. I am inclined to believe, however, that it is not a bird which will be found to yield much sport, as I doubt its lying to settels or 
pointers, or being met with in sufficient numbers to render the pursuit of it pleasurable or exciting.

The single specimen which I killed, rose suddenly from the ground, which was covered with snow to the depth of a foot or more, in a little dell or basin, full of tall larch and spruce-firs, just as I came over the brow of the hill; and I was fortunate enough to kill it at long range, by a snap shot. It was a fine cock bird, agreeing in all respects accurately with the above description, from the pages of the greatest living naturalist.

Feeling that something more than this bare notice is due to this beautiful bird, and with some faint hope that, by calling the attention of sportsmen to the undoubted fact of its existence within our sporting limits, I may add one to our list of game, I shall proceed to quote from the author already noticed, whose ornithological distinctions and descriptions I shall adopt throughout this work, the following graphic account of his experience as relates to this Grouse.

I say, that I entertain but a faint hope, because among many intelligent and observing friends, keen sportsinen and good shots, both in Lower Canada and New Brunswick, I have never heard this Grouse named as a bird of game. In fact, I believe that no bird which haunts the depths of the North American wilderness can, under any circumstances, afford much sport to the legitimate pursuer, though they may be treed with cur-dogs, and shot sitting, in sufficient numbers to supply markets, and to satisfy the sporting aspirations of the prowling, backwoods' gunner.

"No sooner had I entered the State of Maine, than I considered the Canada Grouse as one of the principal objects of my enquiry. Every person to whom I spoke about it, assured me that it was rather abundant during the whole year, and consequently that it bred in the country. All this I fortunately proved to be quite true; but no one told me of the difficulties I should have to encounter in watching its habits; and although I ultimately succeeded in this, the task was perhaps as severe as any which I ever undertook. 
"In August, 1832, I reached the delightful little village of Dennisville, about eighteen miles distant from Eastport. There I had the good fortune to become an inmate of the kind and most hospitable family of Judge Lincoln, who has resided there for nearly half a century, and who is blessed with a family of sons equal to any with whom I am acquainted, for talents, perseverance and industry. Each of these had his own peculiar avocation, and I naturally attached myself more particularly to one who, ever since his childhood, manifested a decided preference for ornithological pursuits. This young gentleman, Thomas Lincoln, offered to lead me to those retired woods, where the Spruce Partridges were to be found. We accordingly set out on the 27th of August, my two sons accompanying us. Thomas, being a perfect woodsman, advanced at our head, and I can assure you, reader, that to follow him through the dense and tangled woods of his native country, or over the deep mosses of Labrador, where he accompanied me afterward, would be an undertaking not easily accomplished. We, however, managed to follow our guide the whole day, over fallen trees, among tangled brushwood, and through miry ponds; yet not a single Grouse did we find, even in the places where he had before seen them; and great was my mortification when, on our return, toward sunset, as we were crossing a meadow belonging to his father, not more than a quarter of a mile from the village, the people employed in making hay informed us that about half an hour after our departure, they had seen a fine covey. We were too much fatigued to go in search of them, and therefore made for home.

"' Ever ardent, if not impatient, I immediately made arrangements for procuring some of these birds, offering a good price for a few pairs of old and young, and in a few days renewed my search, in company with a man, who had assured me he could guide me to their breeding-grounds, which he actually did, to my great pleasure. These breeding-grounds I cannot better describe, than by telling you that the larch forests, which are here called 'Hackmetack Woods,' are as difficult to traverse 
as the most tangled swamps of Labrador. The whole ground is covered by the most beautiful carpeting of verdant moss, over which the light-footed Grouse walk with ease, but among which we sunk at every step or two up to the waist, our legs stuck in the mire, and our bodies squeezed beneath the dead trunks and branches of the trees, the minute leaves of which insinuated themselves between my clothes, and nearly blinded me. We saved our guns from injury, however, and seeing some of the Spruce Partridges before they perceived us, we procured several specimens. They were in beautiful plumage, but all male birds. It is in such places that these birds usually reside, and it is very seldom that they are seen in the open grounds, beyond the borders of their almost impenetrable retreats. On returning to my family, I found that another hunter had brought two fine females, but had foolishly neglected to bring the young ones, which he had caught and given to his children, who, to my great mortification, had already cooked them when my messenger arrived at his house.

"The Spruce Partridge, or Canada Grouse, breeds in the States of Maine and Massachusetts, about the middle of May, nearly a month earlier than at Labrador. The males pay their addresses to the females, by strutting before them on the ground or moss, in the manner of the Turkey-cock, frequently rising several yards in the air, in a spiral manner, when they beat their wings violently against their body, thereby producing a drumming noise, clearer than that of the Ruffed Grouse, and which can be heard at a considerable distance. The female places her nest beneath the low horizontal branches of fir-trees, taking care to conceal it well. It consists of a bed of twigs, dry leaves and mosses, on which she deposits from eight to fourteen eggs, of a deep fawn color, irregularly splashed with different tints of brown. They raise only one brood in the season, and the young follow the mother as soon as they are hatched. The males leave the females whenever incubation has commenced, and do not join them again until late in autumn; indeed, they remove 
to different woods, when they are more shy and wary than during the love season or the winter.

"This species walks much in the manner of our Partridge. I never saw one jerk its tail, as the Ruffed Grouse does; nor do they burrow in the snow, like that bird, but usually resort to trees, to save themselves from their pursuers. They seldom move from thence at the barking of a dog; and, when roused, fly only to a short distance, uttering a few clucks, which they repeat on alighting. In general, when a flock is discovered, each individual forming it may be easily caught ; for, so seldom do they see men in the secluded places they inhabit, that they do not seem to be aware of the hostile propensities of the race.

"Along the shores of the Bay of Fundy, the Spruce Partridge is much more common than the Ruffed Grouse; which, indeed, gradually becomes scarcer the farther north we proceed, and is unknown in Labrador, where it is replaced by the Willow Grouse, and two other species. The females of the Canada Grouse differ materially in their coloring, in different latitudes. In Maine, for instance, they are more richly colored than in Labrador, where I observed that all the individuals procured by me were of a much grayer hue than those shot near Dennisville. The like difference is, perhaps, still more remarkable in the Ruffed Grouse, which are so very gray and uniformly colored in the Northern and Eastern States, as to induce almost every person to consider them as of a species distinct from those found in Kentucky, or any of the southern mountainous districts of the Union. I have in my possession skins of both species, procured a thousand miles apart, that present these remarkable differences in the general hue of their plumage.

"All the species of this genus indicate the approach of rainy weather or a snow storm with far more precision than the best barometer; for, on the afternoon previous to the occurrence of such weather, they all resort to their roosting-places earlier, by several hours, than they do during a continuation of fine weather. I have seen groups of Grouse flying up to their roosts at mid-day, or as soon as the weather felt heavy, and have observed 
that it generally rained in the course of that afternoon. When, on the contrary, the same flock would remain busily engaged in search of food, until sunset, I found the following morning fresh and clear. Indeed, I believe that this kind of foresight exists in the whole tribe of gallinaceous birds.

" One day, while on the coast of Labrador, I accidentally almost walked upon a female Canada Grouse, surrounded by her young brood. It was on the 18th of July. The affrighted mother, on seeing us, ruffled up all her feathers, like a common hen, and advanced close to us, as if determined to defend her offspring. Her distressed condition claimed our forbearance, and we allowed her to remain in safety. The moment we retired, she smoothed down her plumage, and uttered a tender maternal cluck, when the little ones took to their wings, although they were, I can venture to assert, not more than one week old, with so much ease and delight, that I felt highly pleased at having allowed them to escape.

"Two days afterward, my youthful and industrious party returned to the Ripley with a pair of these Grouse in moult. This species undergoes that severe trial at a much earlier season than the Willow Ptarmigan. My son reported that some young ones which he saw with their mother, were able to fly fully a hundred yards, and alighted on the low trees, among which he caught several of them, which, however, died before he reached the vessel.

"This species is found not only in the State of Maine, but also in the mountainous districts of New Hampshire, and the northern parts of New York, as well as around our Northern Great Lakes and the head-waters of the Missouri. It is abundant in the British Provinces of New Brunswick, Nova Scotia, Newfoundland and Labrador.

"Among the great number, procured at all seasons of the year, which I have examined, I never found one without the rufous band at the extremity of the tail ; nor did I see any having the terminal white spot on the upper tail-coverts, exhibited in figures of this species. 
"Their food consists of berries of different sorts, and the young twigs and blossoms of several species of plants. In the summer and autumn, I have often found them gorged with berries of the plant which is commonly called 'Solomon's seal.' In the winter I have seen the crop filled with the short leaves of the larch or hackmetack.

"I have frequently heard it said that these birds could be knocked down with sticks, or that a whole covey could be shot, while perched on trees, by beginning at the lowest one; but I never witnessed anything of the kind, and cannot therefore vouch for the truth of the assertion. During the autumn of 1833, these birds were uncommonly plentiful in the State of Maine. My friend Edward Harris, of New York, Thomas Lincoln, and others, killed a great number; and the latter gentleman procured a pair alive, which were fed on oats and did well.

"The flesh of this Grouse is dark, and fit for being eaten only when it has fed on berries. In winter, when it feeds on the leaves of trees and other plants, the flesh is quite bitter and disagreeable.

"According to Dr. Richardson, all the thick and swampy black spruce forests between Canada and the Arctic ocean abound with this bird, and considerable numbers exist, in the severest seasons, as high as the 67th parallel. I am informed by Mr. Townsend that it is also plentiful on the Rocky Mountains and the plains of the Columbia, from which parts I have obtained specimens differing in nothing from others procured in Maine and Labrador. I have also compared those in the Edinburgh Museum, which Mr. Douglass was pleased to name Franklin's Grouse, with several of my own, and feel confident that they are all of one and the same species."

From this vivid and life-like description of this beautiful little Grouse, its habits, food, motions, and the districts which it inhabits, it will be evident to all that it cannot be denied a place among the Upland game of the United States and British Pro. 
vinces; while it is, I fear, scarcely less apparent that neither its numbers nor its manrers will ever, in probability, allow it to be pursued successfully for the purposes of sport.

In one respect only I must venture to differ from the great authority and venerable man, whom I have quoted above; and this on a point only whereon the least scientific may be allowed to differ from the opinions of the wisest; since it is admitted everywhere that de gustibus non est disputandum. Mr. Audubon says that in winter the flesh is bitter and disagreeable. I have eaten it in winter, and then only, and while I must admit the almost resinous aromatic bitterness, I venture to pronounce it delicious in the extreme; and I believe that all epicures in game will agree with me-all those, I mean, who prefer the back bone and thighs of the Ruffed Grouse of America, or the Moorfowl of the British Isles, to the tamer white meat of the breast. European readers will understand the flavor I allude to, when 1 state that it closely resembles that of the Capercaillie, as imported from Norway in the winter season.

With this species I shall conclude my notice of the Grouse Tetraonide of America, since the Willow Ptarmigan, Tetrao Saliceti, "Red-necked Partridge," is so very rare that it really cannot be included under the head of Game, even that indefatigable explorer, Mr.・Audubon, having failed to discover it within the limits of the States, although he expresses his conviction that "it exists in the State of Maine, as well as in the Northern Districts bordering on the great lakes."

For the benefit of those who desire to be informed, and to learn the distinctions between Grouse, Pheasant, and Partridge, neither of the latter species existing in America, I will state simply and briefly that all Grouse are feathered on the legs, below the termination of the thigh, some quite to the toe nails. The Ruffed Grouse is feathered below the knee-the Pinnated and Canada Grouse to the ancles-the Willow Grouse to the claws. Of many generic marks this is the most decided. No gamebird but the Grouse is feathered below the knee, and he always carries this distinctive sign after the spring migration. 


\section{AMERICAN QUAIL.}

Ortyx Virginiana - Stephens. La Perdrix d'Amerique-Brissot. The Quail,_-"The Partridge" in Pennsylvania and Southward, improperly.

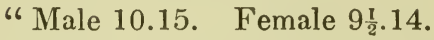

"Breeds abundantly from Texas to Massachusetts; in the interior, high on the Missouri, and in all intermediate districts.

"Adult male.

"Bill short, robust, rather obtuse, the base covered with feathers; upper mandible* with the dorsal outline curved, the sides convex, the edges overlapping, the tip declinate; under mandible nearly straight in its dorsal outline, arched on the edges, the sides convex, nostrils concealed among the feathers. Head and neck of ordinary size; body short and bulky. Feet of ordinary length; tarsus anteriorly scutellate, $\uparrow$ a little compressed, spurless. Toes scutellate above, pectinatef on the sides; claws arched, obtuse.

"Plumage compact, glossy. Feathers of the upper part of the head erectile into a tuft. Wings short, broad, much curved, and rounded; the fourth quill the longest. Tail short, rounded, of twelve rounded feathers.

"Bill dark brown. Iris hazel. Feet grayish blue. The forehead, a broad line over each eye, and the throat and foreneck white. Lore, auricular $\oint$ coverts, and a broad semilunar band on the foreneck, more or less black. Upper part of the head, hind and lower part of the neck, all round, reddish brown. Upper back and wing coverts, bright brownish red; the lower part of the back, light red, tinged with yellow. Primaries dusky, externally margined with blue; secondaries irregularly barred with light red. Tail grayish blue, excepting the middle

* Mandible-division of bill corresponding to the jaws.

+ Scutellate-covered with scales overlapping each cther like tiles.

$\ddagger$ Pectinate-toothed like a comb.

c. A uricular-belonging to the ear. 
feathers, which are dull grayish yellow, sprinkled with black. Sides of the neck spotted with white. Under parts white, streaked with brownish-red, transversely and undulatingly barred with black. Sides and under tail coverts, reddish.

"Length, 10 inches; extent of wings, 15; bill along the back, $\frac{1}{2}$, along the gap, $\frac{7}{12}$; tarsus $\frac{1}{4}$; middle toe nearly the same.

" Young Male.

"Similar to the adult male in the general distribution of the colors, but the white of the head and throat bright reddishyellow; the back of the fore-neck and sides of the head, deep brown; the under parts less pure and more dusky; and the tail of a duller gray.

"Adult Female.

"The female resembles the young male, but is more decidedly colored; the bill darker, the head of a more uniform and richer reddish-yellow; the sides of the neck spotted with yellow and black.

"Young Female.

"The young females are somewhat smaller and lighter in their tints than the young males.

"Very young Birds.

"Bill brownish-yellow. Iris light hazel. The general color of the upper parts, light yellowish-brown, patched with gray; sides of the head dusky."-Audubon's Birds of America.

"This well known bird is a general inhabitant of North America, from the northern parts of Canada and Nova Scotia, in which latter place it is said to be migratory to the extremity of the peninsula of Florida, and was seen in the neighborhood of the Great Osage Village in the interior of Louisiana. They are numerous in Kentucky and Ohio. Mr. Pennant remarks that they have been lately introduced into the Island of Jamaica, where they appear to thrive greatly, breeding in that warm climate twice in the year. Capt. Henderson mentions them as being plenty near the Belize, at the Bay of Honduras. They 
rarely frequent the forest, and are most numerous in the vicinity of well cultivated plantations, where grain is plenty. They, however, occasionally seek shelter in the woods, perching on the branches, or secreting themselves among the brushwood; but are found most usually in open fields, or along fences sheltered by thickets of briars; when they are not too much persecuted by the sportsman they become almost half domesticated, approach the barn, particularly in winter, and sometimes in that severe season mix with the poultry to glean up a subsistence. They remain with us a whole year, and often suffer extremely by long, hard winters, and deep snows. At such times the arts of man combine with the inclemency of the season for their destruction. To the ravages of the gun are added others of a more insidious kind. Traps are placed on almost every plantation in such places as they are known to frequent. They are formed of lath or thinly split sticks, somewhat in the shape of an obtuse cone, laced together with cord, having a small hole at the top with a sliding lid to take out the game by. This is supported by the common figure 4 trigger, and grain is scattered below and leading to the place. By this contrivance ten or fifteen have sometimes been taken at a time. These are sometimes brought alive to market, and occasionally bought up by sportsmen, who, if the season be very severe, sometimes preserve and feed them till Spring, when they are humanely turned out to their native fields again, to be put to death sone future time secundum artem. Between the months of August and March great numbers of these birds are brought to the market of Philadelphia, where they are sold at from twelve to eighteen cents a piece.

"The Quail begins to build early in May. The nest is made on the ground, usually at the bottom of a thick tuft of grass that shelters and conceals it. The materials are leaves and fine dry grass, in considerable quantity. It is well covered above, and an opening left on one side for entrance. The female lays from fifteen to twenty-four eggs, of a pure white, without any spots. The time of incubation has been stated to me by various per- 
sons at four weeks, when the eggs were placed under the domestic Hen. The young leave the nest as soon as they are freed from the shell, and are conducted about in search of food by the female; are guided by her voice, which, at that time, resembles the twittering of young chickens, and sheltered by her wings in the same manner as the domestic fowl, but with all that secrecy and precaution for their safety which their helplessness and greater danger require. In this situation, should the little timid family be unexpectedly surprised, the utmost alarm and consternation prevails. The mother throws herself in the path, fluttering along and beating the ground with her wings, as if sorely wounded, using every artifice she is master of to entice the passenger in pursuit of herself, uttering at the same time certain peculiar notes of alarm, well understood by the young, who dive separately amongst the grass, and secrete themselves until the danger is over, and the parent, having decoyed the pursuer to a safe distance, returns by a circuitous route to collect and lead them off. This well known manœurre, which nine times in ten is successful, is honorable to the feelings and judgment of the bird, but a severe satire on man. The affectionate mother, as if sensible of the avaricious cruelty of his nature, tempts him with a larger prize to save her more helpless offspring, and pays him as avarice and cruelty ought always to be paid, with mortification and disappointment.

" The eggs of the Quail have been frequently placed under the domestic Hen, and hatched and reared with equal success as her own, though generally speaking, the young Partridges, being more restless and vagrant, often lose themselves and disappear. The Hen ought to be a particular good nurse, not at all disposed to ramble, in which case they are very easily raised. Those that survive acquire all the familiarity of common Chickens, and there is little doubt that if proper measures were taken and persevered in for a few years, they might be completely domesticated. They have been often kept during the first season and through the whole of that winter, but have uniformly deserted in the spring. Two young Partridges that 
were brought up by a Hen, when abandoned by her, associated with the cows, which they regularly followed to the fields, returned with them when they came home in the evening, stood by them while they were milked and again accompanied them to the pasture. These remained during the winter, lodging in the stable, but as soon as spring came they disappeared. Of this fact I was informed by a very respectable lady, by whom they were particularly observed. It has been frequently asserted to me that the Quails lay in each others nests. Though I have never myself seen a case of this kind, I do not think it altogether improbable, from the fact that they have often been known to drop their eggs in the nest of the common Hen, when that happened to be in the fields or at a small distance from the house. The two Partridges above mentioned were raised in this manner, and it was particularly remarked by the lady who gave me the information, that the Hen sat for several days after her own eggs were hatched, until the young Quails made their appearance. The Partridge, on her part, has sometimes been employed to hatch the eggs of the common domestic Hen. A friend of mine, who himself made the experiment, informs me that of several Hen's eggs which he substituted in place of those of the Partridge, she brought out the whole, and that for several weeks he occasionally surprised her in various parts of the plantation, with her brood of Chickens, on which occasions she exhibited all that distressful alarm, and practised her usual manœuvres for their preservation. Even after they were considerably grown, and larger than the Partridge herself, she continued to lead them about; but though the notes or call were those of common Chickens, their manners had all the shyness, timidity, and alarm of young Partridges, running with great rapidity, and squatting in the grass exactly in the manner of the Partridge. Soon after this they disappeared, having probably been destroyed by dogs, by the gun, or by birds of prey. Whether the domestic fowl might not by this method be very soon brought back to its original savage state, and thereby supply another additional subject for the amusement 
of the sportsman, will scarcely admit of doubt ; but the experiment, in order to secure its success, would require to be made in a quarter of the country less exposed than ours to the ravages of guns, dogs, traps, and the deep snows of winter, that the new tribe might have full time to become completely naturalized and well fixed in all their native habits. About the beginning of September, the Quail being now nearly full grown and associated in flocks or coveys of from four or five to thirty, afford considerable sport to the gunner. At this time the notes of the male are most frequent, clear, and loud. His common call consists of two notes, with sometimes an introductory one, and is similar to the sound produced by pronouncing the words Bob White. This call may be easily mistaken by whistling, so as to deceive the bird itself, and bring it near. While uttering this he is usually perched on a rail of the fence, or a low limb of an apple tree, where he will sometimes sit repeating, at short intervals, Bob White, for half an hour at a time. When a covey are assembled in a thicket, or corner of a field, and about to take wing, they make a low, twittering sound, not unlike that of young Chickens; and when the covey is dispersed they are called together by a loud and frequently repeated note, peculiarly expressive of tenderness and anxiety. The food of the Partridge consists of grain, seeds, insects, and berries of various kinds. Buckwheat and Indian Corn are particular favorites. In September and October the Buckwheat fields afford them an abundant supply as well as a secure shelter. They usually roost at night in the middle of a field, on high ground, and from the circumstance of the dung being found in such places in one round heap, it is generally conjectured that they roost in a circle with their heads outward; each individual in this position forming a kind of guard to prevent surprise. They also continue to lodge for several nights in the same spot. The Partridge, like all the rest of the gallinaceous order, flies with a loud, whirring sound, occasioned by the shortness, concavity, and rapid motion of its wings, and the comparative weight of its body. The steadiness of its 
horizontal flight, however, renders it no difficult mark to the sportsman, particularly when assisted by his sagacious pointer. The flesh of this bird is peculiarly white, tender and delicate, and unequalled by that of any other of its genus in the United States. There is only one species of Quail at present known within the United States."-Wilson's Am. Ornithology.

\section{THE WOODCOCK.}

Scolopax Minor.-La Becasse d'Amerique-Brissot. The MudSnipe, Blind Snipe, Big-headed Snipe, Bog-Sucker.

"Male, 11.16. Female, 11 $\frac{7}{12} .17 \frac{1}{4}$.

"Distributed throughout the country, extremely abundant in the Middle and Eastern Districts, as well as in the interior, where it breeds as far as Nova Scotia. Equally abundart in winter, in the Southern States, though many migrate Southward.

" Adult Male.

"Bill double the length of the head, straight, slender, tapering, sub-trigonal, and deeper than broad at the base, slightly depressed toward the end. Upper mandible, with the dorsal line straight; the ridge narrow, toward the end flattened; the sides nearly erect, sloping outward toward the soft, obtuse edges; the tip blunt, knob-like, and longer than that of the lower mandible. Nostrils basal, lateral, lineal, very small. Lower mandible broader than the upper; the angle very long and narrow, the dorsal line straight, the back broadly rounded, the sides marked with a deep groove, sloping inward at the base, outward toward the end, the edges soft and obtuse, the tip rounded.

"Head rather large, oblong, narrowed anteriorly ; eyes large, and placed high. Neck short and thick. Body rather full. Feet rather short; tibia feathered to the joint; tarsus rather short, compressed, covered in front by numerous scutella; on the sides and behind with sub-hexagonal scales, and having a row of small scutelliform scales along the outer side behind. Toes free, slender, the first verv sinall, the second slightly 
shorter than the fourth, the third much longes and exceeding the tarsus in length; all scutellate above, marginate, flattish, beneath. Claws very small, arched, acute, that of the hind toe extremely small, of middle toe with a thin inner edge.

" Plumage very soft, elastic, blended; of the fore-part of the head very short; of the neck full. Wings short, rounded; the fourth and fifth quills about equal and longest, the first three extraordinarily attenuated, being in fact sublinear, narrower beyond the middle, the inner web slightly enlarged toward the end, the first as long as the seventh. Secondaries broad, the outer a little incurved and rounded, the inner tapering and elongated. Tail very short, wedge-shaped, of twelve narrow feathers, which taper toward the rounded point.

"Bill light yellowish-brown, dusky toward the end. Iris brown. Feet flesh-colored; claws brownish black. The forehead is yellowish-gray, with a few dark inottlings in the centre. On the upper part of the head are two blackish-brown broad transverse bands, and on the occiput two narrower, separated by bands of light red; a brownish-black loral band and a narrow irregular line of the same across the cheek, and continued to the occiput. The upper parts are variegated with brownish-black, light yellowish-red, and ash-gray. There are three broad, longitudinal bands of the first color, barred with the second, down the back, separated by t'vo of the last. The inner wing coverts and secondary quills are similarly barred; the outer, pale grayish-red, faintly barred with dusky. The quills are grayishbrown, tipped with dull gray, the secondaries spotted on the outer web with dull red. Upper tail coverts barred; tail feathers brownish-black, their tips gray, their outer edges mottled with reddish. The sides of the neck are gray, tinged with red; the lower parts in general, light red, tinged with gray on the breast, on the sides and lower wing coverts deeper; the lower tail coverts with a central dusky line, and the tip white.

"Length to end of tail, 11 inches; to end of wings, $9 \frac{1}{2}$; wing from flexure, $5 \frac{1}{4}$; tail, $2 \frac{4}{12}$; bill along the ridge, $2 \frac{8}{12} ;$ along 
the edge of the lower mandible, $2 \frac{11}{2} ;$ tarsus, $1 \frac{2}{12} ;$ middle toe, $1_{1 \frac{5}{2}}$, its claw, $\frac{1}{4}$; weight, $6 \frac{1}{4} \mathrm{oz}$.

"Adult Female.

" The female, which is considerably larger, has the same colors as the male.

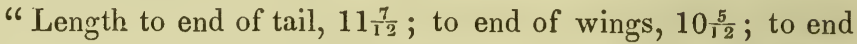
of claws, $13 \frac{4}{12}$; wing, from flexure, $5 \frac{4}{12}$; tail, $2 \frac{4}{12}$; bill along the ridge, $2 \frac{10}{12}$; along the edge of lower mandible, $2 \frac{13}{2} ;$ tarsus, $1 \frac{2}{12}$; middle toe, $1 \frac{5}{12}$; its claw, $\frac{1}{4}$; weight, $8 \frac{1}{2} \mathrm{oz}$.

" Fledged young.

"When fully fledged, similar to the old birds." -Audubon's Birds of America.

"This bird is universally known to our sportsmen. It arrives in Pennsylvania early in March-sometimes sooner-and, I doubt not, in mild winters, some few remain with us the whole of that season.

" During the day they keep to the woods and thickets, and at the approach of evening seek the high and open country places to feed in. They soon disperse themselves over the country to breed. About the beginning of July, particularly in long-continued hot weather, they descend to the marshy shores of our large rivers, their favorite springs and watery recesses inland being chiefly dried up. To the former of these retreats they are pursued by the merciless sportsman, flushed by dogs, and shot down in great numbers. This species of amusement, when eagerly followed, is still more laborious than Snipe-shooting; and, from the nature of the ground, or " cripple," as it is usually called-viz., deep mud intersected with old logs, which are covered and hid from sight by high reeds, weeds, and alder bushes-the best dogs are soon tired out, and it is customary with sportsmen who regularly pursue this diversion, to have two sets of dogs to relieve each other alternately.

"The Woodcock usually beging to lay in April. The nest is placed on the ground, in a retired part of the woods, frequently at the root of an old stump. It is formed of a few withered 
leaves and stalks of grass, laid with very little art. The female lays four, soinetimes five eggs, about an inch and a half long, and an inch, or rather more, in diameter, tapering suddenly to the small end. These are of a dull clay color, marked with spots of brown, particularly at the great end, and interspersed with others of a very pale purple. The nest of the Woodcock has, in several instances that have come to my knowledge, been found with egrgs in February, but its usual time of beginning to lay is in April. In July, August and September, they are considered in good order for shooting. The Woodcock is properly a nocturnal bird, feeding chiefly at night, and seldom stirring about till after sunset. At such times, as well as in the early part of the morning, particularly in the spring, he rises by a kind of spiral course, to a considerable height in the air, uttering at times a sudden quack, till having gained his utmost height, he hovers around in a wild and irregular manner, making a sort of murmuring sound, then descends with rapidity, as he rose. When uttering his common note on the ground, he seems to do it with difficulty, throwing his head toward the earth, and frequently jetting up his tail. These notes and mancuvres are most usual in the spring, and are the call of the male to his favorite female. Their food consists of various larve and other aquatic worms, for which, during the evening, they are almost continually turning over the leaves with their bills, or searching in the bogs. Their flesh is reckoned delicious, and prized highly. They remain with us till late in the autumn, and, on the falling of the first snows, descend from the ranges of the Alleghany to the lower parts of the country, in great numbers-soon after which, viz., in November, they move off to the South. This bird, in its general figure and manners, very greatly resemble the Woodcock of Europe ; but is considerably less, and differently marked below, being an entirely distinct species. A few traits will clearly point out these differences. The lower parts of the European Woodcock are thickly barred with dusky-waved lines on a yellowishwhite ground. The present species has those parts of a bright ferruginous. The male, of the American species, weighs from 
five to six ounces, the female eight; the European twelve. The European Woodcock makes his first appearance in Britain in October and November, that country being, in fact, only its winter quarters; for, early in March, they move off to the northern parts of the continent to breed. The American species, on the contrary, winters in countries south of the United States; arrives here early in March, extends its migration as far at least as the river St. Lawrence-breeds in all the intermediate places, and retires again to the South on the approach of winter. The one migrates from the torrid to the temperate regions-the other from the temperate to the Arctic. The two birds, therefore, notwithstanding their names are the same, differ not only in size and markings, but also in native climate. Hence the absurdity of those who would persuade us that the Woodcock of America crosses the Atlantic to Europe, and vice versa. These observations have been thought necessary, from the respectability of some of our own writers, who seem to have adopted this opinion. How far to the North our Woodcock is found, I am unable to say. It is not mentioned as a bird of Hudson's Bay, and being altogether unknown in the Northern parts of Europe, it is very probable that its migrations do not extend to a very high latitude; for it may be laid down as a general rule, that those birds which migrate to the Arctic regions, in either continent, are very often common to both. The head of the Woodcock is of singular conformation-large, somewhat triangular, and the eye fixed at a remarkable distance from the bill, and high in the head. This construction was necessary to give a greater range of vision, and to secure the eye from injury while the owner is searching in the mire. The flight of the Woodcock is slow. When flushed at any time in the woods, he rises to the height of the bushes or underwood, and almost instantly drops behind them again at a short distance, generally running off for several yards as soon as he touches the ground. The notion that there are two species of Woodcock in this country, probably originated from the great difference of size between the male and femalethe latter being considerably the larger. When taken, they ut- 



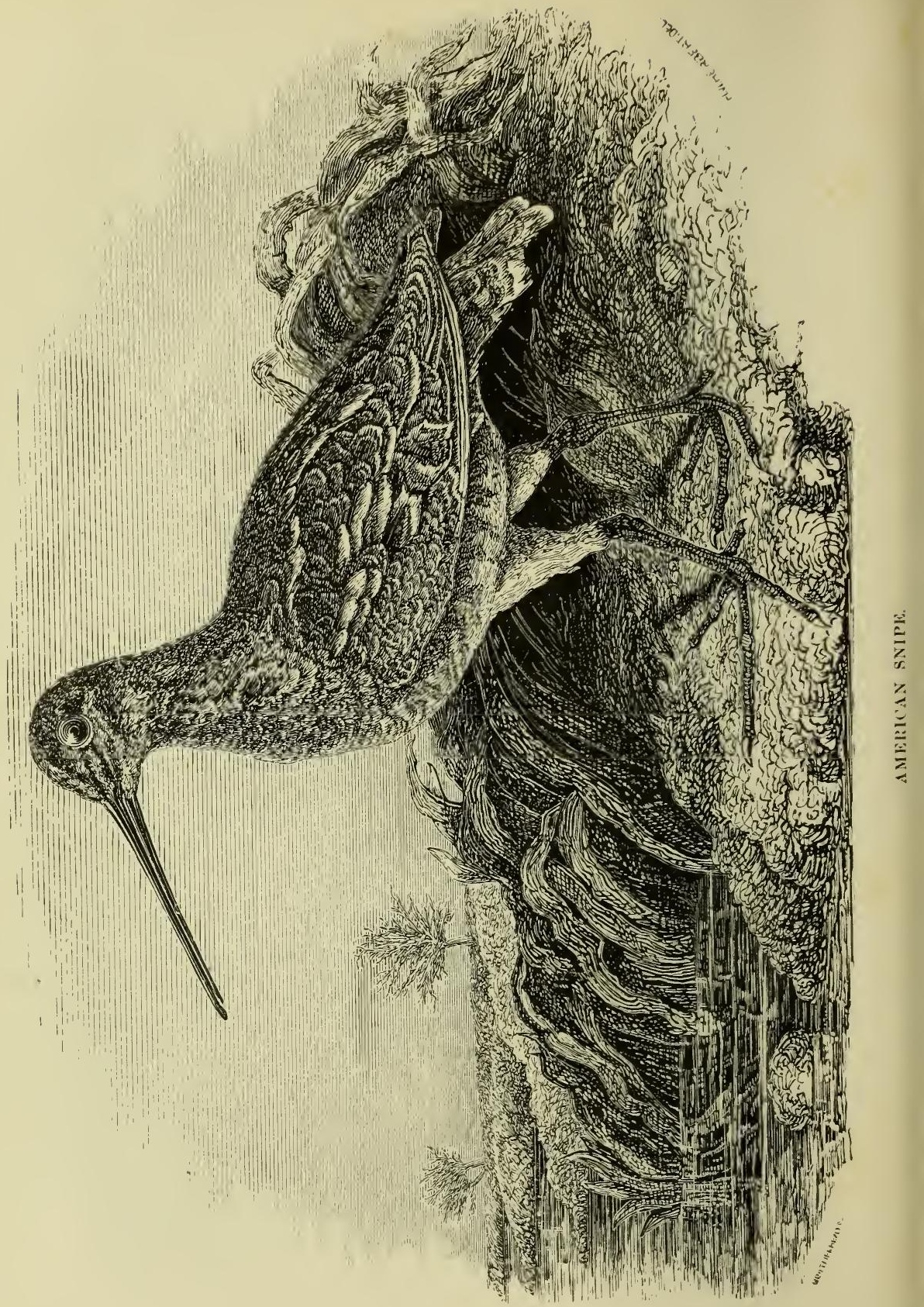


.er a long, clear, but feeble peep, not louder than that of a mouse. They are far inferior to young partridges, in running and skulking, and, should the female be unfortunately killed, may be easily taken on the spot."-Wilson's Am. Ornithology.

\section{COMMON SNIPE.}

\section{Scolopax Wilsonii.-The English Snipe.}

" Male $10 \frac{1}{2} \cdot 17$.

" Distributed throughout the country. Breeds from Virginia northward. Exceedingly abundant in the Southern and Western districts during winter.

"Adult male.

"Bill twice as long as the head, subulate, straight, depressed toward the end, compressed for more than half its length. Upper mandible with the dorsal line straight; the ridge, for a short space at the base, flattish, then convex; towards the end flattened; the sides with a narrow groove extending to near the tip, which is obtuse and probe-like; the edges soft and obtuse. Nostrils basal, linear, very small. Lower mandible with the angle extremely narrow and long, the sides nearly erect, with a groove having several bars across it; the end of both mandibles covered, after death, with numerous prominences, or rather with reticular depressions, leaving small prominences between them.

"Head rather small, oblong, narrowed anteriorly, the forehead elevated and rounded. Neck rather short. Body rather full. Legs of moderate length, slender; tibia bare below, scutellate before and behind; tarsus with numerous scutella before, smaller ones behind, and reticulated sides; toes very slender, free, scutellate above, narrow and slightly margined beneath; first very small, third longer than the tarsus; fourth much shorter, but considerably longer than the second. Claws slightly arched, extremely compressed, very acute, that of the third toe longest.

"Plumage very soft, rather full, blended; on the forepart 
of the head very short. Wings of moderate length, narrow sharp; primaries broad, tapering, but rounded, the first ex tremely small and pointed, the second longest, the third very little shorter, the rest rapidly graduated; secondaries broad, short, incurved, rounded, the inner very long, tapering, as are the scapulars. Tail short, rounded, of sixteen rounded feathers.

"Bill brown, the granulated part toward the tip black. Iris hazel. Feet bluish gray, claws dusky. On the upper part of the head two brownish-black longitudinal bands, separated by a narrower central pale brown one, and with another pale brown band on each side from the bill over the eye. Then a loral band of dark brown; chin whitish; neck pale reddishbrown, spotted with brownish-black. The general color of upper parts is brownish-black, variegated with pale reddishbrown, of which latter color are the outer edges of the scapulars and of the lateral feathers on the anterior part of the back. Wing-coverts, and inner secondaries, similarly mottled; the small anterior coverts, the primary coverts, primary quills, and outer secondaries, deep brown more or less tipped with white; rump barred with yellowish-gray and dusky; upper tail coverts similar, but the larger barred with brownish-red and black. Tail feathers brownish-black at the base, with a broad subterminal band of brownish-red on the outer web of the two middle, and on both webs of the rest, excepting the outer on each side, which is barred with brownish-black and white, the black bars five; the tips of all white. Anterior part of breast like the neck, the rest white; abdomen and lower tail coverts grayish-yellow, barred with brownish-black; lower wing coverts similarly mottled.

" Length to end of tail, $10 \frac{1}{2}$ inches; to end of claws, $11_{2}^{1}$; extent of wings, 17 ; wing, from flexure, 5 ; tail, $2 \frac{1}{4}$; bill along the back, $2 \frac{7}{12}$; along the edge of the lower mandible, $2 \frac{5}{12} ;$ tarsus, $1 \frac{2}{1 \frac{2}{2}}$; middle toe, $1 \frac{1}{4}$; its claw, $\frac{9}{24}$; weight $30 z$.

"Adult female.

"The female resembles the male, but is rather larger." Audubon's Birds of America. 
"This bird is well known to our sportsmen, and if not the same, has a very near resemblance to the common Snipe of Europe. It is usually known by the name of the English Snipe, to distinguish it from the Woodcock, and from several others of the same genus.

"It arrives in Pennsylvania about the 10th of March, and remains in the low grounds for several weeks, the greater part then move off to the north and to the higher inland districts, to breed. A few are occasionally found and consequently breed in our low marshes during the summer. When they first arrive they are usually lean, but when in good order are accounted excellent eating. They are perhaps the most difficult to shoot of all our birds, as they fly in sudden zigzag lines, and very rapidly. Great numbers of these birds winter on the rice grounds of the Southern States, where, in the month of February, they appeared to be much tamer than they usually are here, as I have' frequently observed them running about among the springs and watery thickets. I was told by the inhabitants that they generally disappeared in the spring. On the 20th of March I found these birds extremely numerous on the borders of the ponds near Louisville, $\mathrm{Ky}$, and also in the neighborhood of Lexington, in the same State, as late as the 10th of April. I was told by several people that they are abundant in the Illinois country up as far as Lake Michigan. They are but seldom seen in Pennsylvania during the summer, but are occasionally met with in considerable numbers, on their return in autumn, along the whole east side of the Alleghany, from the sea to the mountains. They have the same soaring, irregular flight in the air, in gloomy weather, as the Snipe of Europe; the same bleating note, and occasional rapid descent, spring from the marshes with the like feeble squeak, and in every respect resemble the common Snipe of Great Britain, except in being about an inch less, and in having sixteen feathers in the tail instead of fourteen, the number said by Bewick to be in that of Europe. From these circumstances we must either conclude this to be a different species, or partially 
changed by difference of climate; the former appears to me the most probable opinion of the two.

"These birds abound in the meadows and low grounds along our large rivers, particularly those that border the Schuylkill and Delaware, from the 10th of March to the middle of April, and sometimes later, and are eagerly sought after by our gunners. The nature of the grounds, however, which these birds frequent, the coldness of the season, and peculiar shyness and agility of the game, renders this amusement attractive only to the most dexterous, active, and eager of our sportsmen." Wilson's Am. Ornithology.

The last of what may be called the purely Upland game birds of North America, is that commonly known as the UP- land Plover, also called the Frost Bird and Grass Plover, from the places which it frequents, and the periods at which it is found in perfection. It is, in my opinion, with no exception, unless perhaps it be the Canvass Back Duck, the most delicious bird that flies. Though generally known as a Plover, it does not belong to that species, but to that of Totanus, Tatler, a sort of connecting link between the Snipes and Sandpipers-the Plover proper having no hind toe. This is the only one of the three families above named that is, in the United States, a land bird, its habits being those of the European Golden Plover, the American namesake of which is essentially a shore bird. The Upland Sandpiper, or Tatler, is thus described by Mr. Audubon:

\section{BARTRAM'S TATLER.}

Totanus Bartramius-Upland Plover, Upland Sandpiper, Frost bird, Grass Plover.

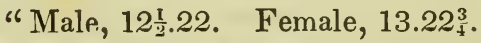

"From Texas along the coast to Nova Scotia. Breeds from Maryland northward to the Saskatchewan. In vast flocks in Louisiana, Oppelousas, and the Western Prairies, in autumn and spring. Rare in Kentucky. 
" Adult Male.

"Bill a little longer than the head, slender, straight; slightly deflected at the end. Upper mandible with the dorsal line straight, the edges convex, the sides grooved beyond the middle, afterward convex, the edges inflected, the tips a little deflected, and tapering to an obtuse point. Nostrils sub-basal, lateral, linear, pervious, nearer the edge than the dorsal line. Lower mandible with the angle very narrow and elongated, beyond it the outline slightly convex, the sides sloping outward and concave until the middle, afterward flattened, the edges sharp, the point very narrow.

"Head rather small, convex above, compressed. Neck of moderate length, slender. Body rather slender. Feet long and slender, tibia bare about half its length, scutellate before and behind ; tarsus long, slender, having before and behind numerous scutella; the narrow lateral spaces with very small, oblong scales. Toes slender; the first very short, the second much shorter than the fourth, the third and fourth connected at the base by a web; the scutella numerous ; claws small, compressed, slightly arched, rather blunt.

" Plumage soft; on the neck and lower parts blended; on the upper rather distinct. Wings rather long, acute, narrow. Primaries tapering and rounded; the first longest, the second a little shorter, the rest rapidly graduated; secondaries obliquely rounded, the inner elongated and tapering. Tail of moderate length, much rounded, of twelve rather narrow feathers.

"Bill yellowish-green, tip dusky, the edges toward the base yellow. Iris dark hazel. Legs and tarsi light yellowish-gray, toes rather darker, claws brownish-black. Upper part of the head dark brown, with a median pale yellowish brown line; the margins of the feathers also of that color which prevails along the sides of the head and the back of the neck, which are streaked with dusky; the eye surrounded with yellowish-white. Throat yellowish-white, without spots ; forepart and sides of the neck, with a portion of the breast and sides of the body, creamcolored, with dusizy lines, which gradually become arrow-shaped 
on the breast, forming a double transverse band; the feathers on the side barred; the rest of the lower parts and lower wing coverts white, banded with brownish-black. On the upper parts the feathers are dark brown, glossed with green, with rich cream-colored margins; the rump darker. On the margins of the scapulars, within the pale edge, is a series of dusky spots which, toward the end, become continuous. Alula, primary coverts, and primary quills blackish-brown, the inner webs crossed by white bands, until about an inch from the end; the shaft of the first quill white, those of the rest dusky. Secondaries grayish-brown, their outer margins pale brown with dusky spots; the inner darker. The two middle feathers of the tail are dark olive, tinged with gray, transversely barred with black, the last bar arrow-shaped, the margins light cream-color, the next feather on each side lighter, and tinged with yellowishred; the rest gradually lighter, the outer white, all barred with black.

"Length to the end of tail, $12 \frac{1}{2}$ inches; to the end of wings, $11 \frac{1}{8}$; to the end of the claws, $13 \frac{1}{2}$; extent of wings, 22 ; wing from flexure, 7 ; tail, $3 \frac{3}{4}$; base part of tibia, $\frac{9}{10}$; tarsus, $1 \frac{3}{2^{4}}$; first toe, $\frac{4}{12}$; claw, $\frac{3}{24}$; bill along the ridge, $1 \frac{2}{12}$; along the edge of lower mandible, $1 \frac{3}{12}$; weight, $6 \mathrm{oz}$.

"Female.

"The female is a little larger, and weighs 7oz., but resembles the male in color. The individual of which the weight is here given, was very fat; but I have never met with any that weighed three-fourths of a pound, as described by Wilson.

"The Bartramian Sandpiper is the most truly terrestrial of its tribe with which I am acquainted. It is even more inclined at all seasons to keep away from water than the Kildeer Plover, which may often be seen along the sandy or muddy margin of the shores of the sea, or of fresh-water lakes and streams. Although not unfrequently met with in the vicinity of such places, it never ventures to wade into them; and yet the form and length of its legs and feet, would naturally induce a person not acquainted with its habits, to consider it as a wading-bird. 
" The dry, upland plains of those sections of Louisiana, called Oppelousas and Attakapas; are amply peopled with this species early in spring, as well as in autumn. They arrive there from the vast prairies of Texas and Mexico, where they spend the winter, in the beginning of March or about the first appearance of the Martins-Hirundo Purpurea-and return about the first of August. They are equally abundant on all the Western Prairies on either side of the Missouri, where, however, they arrive about a month later than in Louisiana, whence they disperse over the United States, reaching the Middle Districts early in May, and the State of Maine by the middle of that month, or about the same period at which they are seen in Indiana, Kentucky and Ohio. Some proceed as far north as the plains adjoining the Saskatchewan River, where Dr. Richardson met with this species in May.

"It has been supposed that the Bartramian Sandpiper never forms large flocks; but this is not correct-for in the neighborhood of New Orleans, where it is called the 'Papabote,' it usually arrives, in great bands, in spring, and is met with on the open plains and large grassy savannahs, where it generally remains about two weeks, - though sometimes individuals may be seen as late as the 15th of May. I have observed the same circumstance on our Western Prairies, but have thought that they were afterward obliged to separate into small flocks, or even into pairs, as soon as they are ready to seek proper places for breeding in; for I have seldom found more than two pairs with nests or young in the same field or piece of ground. On their first arrival, they are generally thin, but on their return southward, in the beginning of August, when they tarry in Louisiana until the first of Octuber, they are fat and juicy. I have observed that, in spring, when they are poor, they are usually much less shy than in autumn, when they are exceedingly wary and difficult of approach; but this general observation is not without exceptions, and the difference, I think, depends on the nature of the localities in which they happen to be found at either period. When on newly-ploughed fields, which they are fond of fre- 
quenting, they see a person at a greater distance than when they are searching for food among the slender grasses of the plains. I have also thought that the size of the flocks may depend upon similar contingencies; for this bird is by no means fond of the society of man.

"Like the Spotted Sandpiper-Totanus Macularius-they not unfrequently alight on fences, trees and out-houses; but, whether in such situations or on the ground, they seldom settle without raising both wings upright to their full extent, and uttering their loud, prolonged and pleasing notes They run with great activity, stop suddenly, and vibrate their body once or twice.

"When earnestly followed by the sportsman, they lower their neads in the manner of Wilson's Plover, and the species called the Piping, and run off rapidly, or squat, according to the urgency of the occasion. At other times, they partially extend their wings, run a few steps as if about to fly, and then cunningly move off sideways, and conceal themselves among the grass, or behind a clod. You are unfrequently rendered aware of your being near them by unexpectedly hearing their plaintive and mellow notes, a circumstance, however, which J always concluded to be indicative of the wariness of their disposition; for, although you have just heard those well-known cries, yet, on searching for the bird itself, you nowhere see it-. for the cunning creature has slipped away and hid itself. When wounded in the wing, they run to a great distance, and are rarely found.

"Like all experienced travellers, they appear to accommodate themselves to circumstances, as regards their food-for in Louisiana they feed on cantharides and other coleopterous insects ; in Massachusetts on grasshoppers, on which my friend NuTTALL says they soon grow fat; in the Carolinas on crickets and other insects, as well as the seeds of the crab-grass-Digitaria Sanguinaria-and in the Barrens of Kentucky they often pick the strawberries. Those which feed much on cantharides require tc be very carefully cleaned, otherwise persons eating 
them are liable to suffer severely. Several gentlemen of New Orleans have assured me that they have seen persons at dinner obliged to leave the room at once, under such circumstances as cannot well be described here. When flavored with the ripe strawberries on which they have fed, their flesh is truly delicious.

"This species performs its migrations by night as well as by day. Its flight is rather swift, and well sustained. While travelling, it generally flies so high as to be beyond the reach of the gun; but, if the weather be cloudy, or if it blow hard, it flies lower, and may be easily shot. It generally proceeds in straggling bands, and moves along with continuous easy beats of its wings, but sails as it were, when about to alight, as well as during the love season.

"As long ago as 1805 and 1806, I observed this species breeding in the meadows and green ficlds of my plantation of Millgrove, near the banks of the Perkioming Creek. Since then, I have known of its rearing broods in different parts of Pennsylvania, in the State of New York, and in various districts to the Eastward, as far as the confines of Maine; but I did not find it in Newfoundland or Labrador; and I have reason to believe that it does not breed to the south of Maryland.

"I have found the eggs of this bird laid on the bare earth, in a hollow, scooped out to the depth of about an inch and a half, near the roots of a tuft of rank grass, in the middle of a meadow ; and have seen some nests of the same species formed of loosely-arranged grasses, and placed almost beneath low bushes, growing on poor, elevated ridges, furnished with a scanty vegetation. When disturbed while on its nest, but unobserved, it runs thirty or forty yards, and then flies off, as if severely wounded. Should it have young, its attempts to decoy you away are quite enough to induce you to desist from distressing it. The eggs measure an inch and five and a-half eighths by an inch and a quarter in their greatest breadth. In form they resemble those of the Totanus Macularius, being broadly rounded at one end and rather pointed at the other; their surface smooth, 
their ground color dull grayish-yellow, with numerous spots of light purple and reddish-brown. They are placed in the nest in the same manner as those of the Spotted Sandpiper; that is, with the smaller ends together; which is also the case with those of the Telltale Godwit, Wilson's Plover, and the Kildeer Plover."-Audubon's Birds of America.

From these seven species, constituting the Upland Game Birds, proper, of the United States-for reasons which have been stated above, I prefer to consider the Wild Turkey under the head of Western Sporting-I come to the two varieties of Hare-Pseudo Rabbit, and White Rabbit; the true genera and distinctive marks of which are subjoined.

\section{THE A MERICAN HARE.}

\section{Lepus Americanus. Lepus Virginianus.}

I have already mentioned, that there is no variety of Rabbit found on this continent; although, from the smaller size, the lighter and grayer color of its fur, and its general resemblance to the wild Rabbit of Europe, the smaller species-Lepus Americanus-which is found in almost every part of the United States and Canada, is invariably termed, and very generally believed to be a Rabbit.

This misnomer is not, like the calling Grouse "Pheasant, and Partridge," a mere error in nomenclature, used by persons who are well aware of the distinction, and sometimes adopt the false instead of the true name, as it were compulsorily, and in order to make themselves understood by the ignorant-as I have found myself obliged to term Woodcock Blind Snipe, in conversation with country people-but is an absolute mistake, which is held by many sportsmen, who will not be convinced of the contrary.

Sportsmen are, indeed, but too apt to undervalue, and even ridicule, the minute distinctions of the naturalist ; not understanding how so small differences as are in some questions alone de- 
cisive of species and genera, can be of the weight ascribed to them; and will persist, even after they are informed to the contrary, in supporting their own opinion against the definitions of science; which is, in fact, not one whit less ridiculous than it were for any one to dispute with the philosopher the earth's roundness, or the sun's volume, because his eyes cannot discern all that is taught by science.

The European Hare, it is well known, is more than double the size and weight of the American variety; weighing, when full grown, from six to eight pounds; and measuring two feet in length-while the American congener is not above eighteen inches long, at the utmost, and does not weigh above two pounds. It is natural enough, therefore, that the European sportsman should be inclined to doubt the fact, associating his ideas of the animal with the large kind which he has hunted or shot at home, when he is told that the little grayish creature, which so very closely resembles the Rabbit of his country in size, is not a Rabbit but a Hare.

In many points, moreover, connected with his haunts, habits and history, the small Hare of America resembles the Rabbit of the eastern continent; although in others more marked, and, inindeed, positively decisive of his species, the two animals differ entirely.

The points of similarity lie in this, that the smaller American Hare, like the Rabbit of Europe, loves craggy and inaccessible wooded hill-sides; and, when hard pressed by dogs, will betake itself to holes and clefts in the rock; and that he has the same skulking habit, and much the same motion.

The great difference is, that he never dwells in vast congrega tions, or warrens, and never burrows in the earth for his habitual dwelling-place. This point, with some others, of structure and breeding, is decisive against his being a Rabbit.

\section{"The American Hare-Lepus Americanus-vuly. The Rabbit.} " S,ength, from nose to tip of hind claws, 16 incnes; length 
of hind legs, $10 \frac{4}{12}$; of head, $3 \frac{8}{12}$; of ears, $3 \frac{2}{12}$; of tail, $2 \frac{8}{1 \frac{8}{2}}$; weight, 3 to $4 \mathrm{lbs}$.

"Ears shorter than the head. Forehead convex. Claws sharp-pointed, and nearly straight. Upper anterior incisors white, with a deep, longitudinal groover near their inner margin; the small incisors behind short, oppressed to the anteriur incisors, and inserted into the upper maxillary. First molar above simple, recurved; the four succeeding larger, and of nearly equal size, composed of double folds of enamel; the last simple, cylindrical, directed forward, and scarcely attaining the length of its predecessors. Beneath, the incisors are smooth, in front long and subquadrate. The first molar inclined backward, grooved before, and with a double groove on the outer surface; the succeeding ones to the last upright, nearly equal, with a single groove and two prominent ridges on their external surfaces ; the last smallest, inclined forward, with a slight groove on the external surface, and the tip exhibits a double case of enamel.

"Color.-In summer the general color is yellowish-brown, which becomes more or less rufous on the outer surface of the extremities and on the breast. Margin of the eyes blackishbrown, and outside of this a circle of yellowish-white. Throat and under side of the tail white. Abdomen grayish-white. Ears edged with white and tipped with brown. Fur plumbeous, lead-colored at the base, and for much of its length. In winter the fur becomes longer, and the upper surface of the head and body lighter, occasionally iron-gray; but I have never seen it as white as is stated by Godman. There may, however, be white varieties; but it cannot be said to have two distinct coats of fur.

" The most remarkable distinctions of this species, by which it is discernible alike from the Rabbit and the common Hare of America, are as follows :-1st. His size, which is much inferior to that of the common or variable Hare, and little superior to that of the common wild Rabbit of Europe ; whence he is frequently confounded with the Rabbit. 2d. The proportion of his legs; the hind legs being longer, the fore legs shorter than those of the larger Hares. 3d. The color and length of the ears, which 
have a black margin at the outside, and no black mark at the tip, and are also shorter than those of the common Hare. 4th. The upper side of the tail is less black. 5th. The body is grayer than that of the other species of Hare. 6th. Its habits, which are purely those of a Hare, as distinct from those of the Rabbit.

"Unlike its congener, the Northern or Varying Hare, it does not confine itself to the woods, but is frequently found in open fields, or where there is a slight copse or underbrush. It never burrows, like its closely-allied species, the European Rabbit, but makes its form, which is a slight depression in the ground, sheltered by some low shrub. It frequently resorts to a stone wall, a heap of stones, or a hollow tree, and sometimes to the burrow of some other animal. Its food consists of bark, buds, grass, wild berries, \&c. Its habits are nocturnal. It breeds three times in the season, producing from four to six at a birth. It has not a wide geographical range, being found from New Hampshire to Florida. Its western limits are not yet ascertained."-Dekay's Nat. Hist. of N. York, \&c.

In addition to this, I think it well to observe, that this is a solitary animal, not gregarious and congregating in large companies, and not breeding monthly, like the European Rabbit; and that, so far as my own observation goes, it does not change its color in winter. Dr. Dekay evidently leans to this latter opinion, in spite of other authorities, who have evidently confounded this with the following species:

THE NORTHERN HARE.

Varying Hare-Lepus Virginianus.-Vulgo, White Rabbit.

"Length of head and body, 20-25 inches; of the hind legs', $11 \frac{2}{12}$; of fore legs, $6 \frac{5}{12}$; of the head, $3 \frac{6}{12}$; of the ears, $3 \frac{4}{12}$; of the tail, $1 \frac{5}{12}$; weight, $6 \frac{1}{2} \mathrm{lbs}$.

"Head short; nose blunt; eyes large and prominent; ears broad and approximated; upper anterior incisors long and slen- 
der, moderately grooved; the small posterior incisors not as large as in the preceding species; lower incisors wedge-shaped, nearly straight. Molars more compressed and broader than in the preceding species. Skull depressed between the orbits. Body covered with loose, shaggy hair. Feet thickly covered with hair above and beneath, concealing the long, thin, and slightly curved claws. Whiskers long and numerous, black, or black and white; a tuft of three or four over the eyes, and some beneath the chin.

"Independently of the change by season of this Hare, it may" be said that at no time, unless in high northern latitudes, can two individuals be found marked precisely alike. At all seasons the base of the fur is lead colored above, and white beneath.

"Winter Dress.-White, or nearly so, with irregular spots and dashes of a bright fawn color, which is more apparent on the ears, forelegs and rump ; ears margined with blackish-brown above, being deeper toward the tips; tail, and all beneath, white.

"S Summer Dress.-Above, bright fawn or reddish-brown; forehead, cheeks and ears of the same color; all beneath, white; edges of the ears white, bordered with darker, particularly toward the tip. At all seasons the hair on the soles is dirty white. Margin of the eyelids, dark brown; pupil dark brown. Iris yellowish.

"It is a distinct variety, differing in many respects from the common Hare, Lepus Timidus, the Varying Hare, Lepus Variabilis, and the Alpine Hare, Lepus Glacialis, of Europe.

"It is found from Canada as far north as Hudson's Bay; southerly to the northern parts of Pennsylvania, perhaps even of Virginia ; but in the Middle States is only found in mountainous and roughly wooded districts.

"Its period of gestation is about six weeks; it bears from four to six young at a litter.

"The flesh of this and the preceding species is insipid, dry, and savorless, depending entirely on the condiments and cooking for its moderate goodness."-Dekay's Nat. Hist. 
With these seven birds and two quadrupeds I might properly enough close my enumeration of our Upland game. There are, however, six species of Duck, which I have named above-THE Duskx, vulgo Black Duck; The Mallard; The Blue-winged and The Green-winged Teal; The Summer, or Wood Duck ; and The Pintail Duck; all of which, although water fowl, may be regarded with great fitness as Upland game, since they all frequent fresh lakes, marshes, and streams-are frequently killed in swamps far inland, and many hundreds of miles above tide water, and with but one exception, are rarely met with or taken, in very great abundance, on the sea-shores, or even on salt marshes.

The Dusky Duck is indeed a frequenter of the bays and of Long Island Sound; I have, however, shot him so often, even over dead points from setters, on inland meadows-his flesh is so far superior when so taken, and above all, he so evidently prefers fresh feeding grounds, so long as the weather will permit-that I must regard him rather as Upland than Shore game. The American Widgeon, and The Shoveller, are so rare, except on the great western waters, which are indeed frequented by almost every variety of fowl, excepting only a few of the purely SEA Ducks, that it is needless to do more than name them. The varieties of the Merganser, generally known as Sheldrake, though sufficiently abundant, I can scarce bring myself to regard as game, their flesh being so rank and fishy as to be scarcely eatable. The six varieties above named, as being the most delicious, and in plumage the most beautiful of the whole duck tribe, must not be passed over so lightly.

The first of these which I shall mention as being worthy of remark as the parent stock of our domestic Duck and Drake, second in succulence and flavor to none but the Canvass Back and Red-head, and superior to all except the Wood Duck in beauty, is the Mallard. 
THE MALLARD.

Anas Boschas-le Canard Sauvage.-Brissot. The Greenhead.

"Male 24.36. Female 22.

"Breeds from Texas sparingly throughout the United States, Columbia River, and Fur Countries. Abundant during the winter in all the Southern Districts; not found in Maine, or Eastward.

Adult male.

"Bill about the length of the head, higher than broad at the base, depressed and widened toward the end, rounded at the tip. Upper mandible with the dorsal outline sloping, and a little concave; the ridge at the base broad and flat, toward the end broadly convex, as are the sides, the edges soft and rather nbtuse; the marginal lamellæ transverse, fifty on each; the unguis oval, curved, abrupt at the end. Nasal groove elliptical, sub-basal, filled by the soft membrane of the bill; nostrils subbasal, placed near the ridge, longitudinal, elliptical, pervious. Lower mandible slightly curved upward, with the angle very long, narrow, and rather pointed, the lamellæ about sixty.

"Head of moderate size, oblong, compressed; neck rather long and slender, body full, depressed. Feet short, stout, placed a little behind the centre of the body. Legs bare a little above the joint; tarsus short, a little compressed, anteriorly with scutella, laterally and behind with small reticulated scales. Hind toe extremely small, with a very narrow membrane; third toe longest; fourth a little shorter, but longer than the second; all the toes connected by reticulated membranes, the outer with a thick margin, the inner with the margin extended into a slightly lobed web. Claws small, arched, compressed, rather acute; that of the middle toe much larger, with a dilated, thin inner edge.

"Plumage, dense, soft, elastic ; of the head and neck, short, blended, and splendent. Of the other parts in general, broad 
ana rounded. Wings of moderate length, acute; primaries narrow and tapering; the second longest, the first very little shorter; secondaries broad, curved inward, the inner elongated and tapering. Tail short, much rounded, of sixteen acute feathers, of which the four central are recurved.

"Bill greenish-yellow. Iris dark brown. Feet orange-red. Head and upper part of neck deep green, a ring of white about the middle of the neck; lower part anteriorly, and fore part of breast dark brownish-chestnut; fore part of back light yellowishbrown, tinged with gray; the rest of the back brownish-black; the rump black, splendent with green and purplish-blue reflections, as are the recurved tail feathers. Upper surface of wing: grayish-brown; the scapulars lighter, except their inner webs, and with the anterior dorsal feathers minutely undulated with brown. The speculum, or beauty spot, on about ten of the secondaries, is of brilliant changing purple and green, edged with velvet-black and white, the anterior bands of black and white being on the secondary coverts. Breast, sides, and abdomen, very pale gray, minutely undulated with darker; lower tail coverts black, with blue reflections.

"Length to the end of tail, 24 inches; to the end of the claws, 23 ; to the tips of the wings, 22 ; extent of wings, 36 ; wing from flexure, $10 \frac{1}{2}$; tail, $4 \frac{1}{4}$; bill, $2 \frac{2}{12}$; tarsus, $1 \frac{3}{4}$; middle toe, $2 \frac{3}{12}$; its claw $\frac{5}{12}$; weight, from $2 \frac{1}{2}$ to 3 lbs.

"Adult female.

"Bill black in the middle, dull orange at the extremities and along the edges. Iris as in the male, as are the feet. The general color of the upper parts is pale yellowish-brown, streaked and spotted with dusky brown. The feathers of the head are narrowly streaked, of the back with the margin and a :entral streak yellowish-brown, the rest of the scapulars similar, but with the light streak on the outer web. The wings are nearly as in the male; the speculum similar, but with less green. The lower parts dull olive, deeper on the lower neck, and spotted with brown.

"Length, 22 inches ; weight, from 2lbs. to $2 \frac{1}{2}$. 
"The young acquire the full plumage in the course of the first winter."-Audubon's Birds of America.

"The common Wild Duck is found in every fresh water lake and river of the United States, in winter, spring, or autumn, but seldom frequents the sea shore or salt marshes. Their summer residence is the North, the great nursery of this numerous genus. Instances have been known of some solitary pairs breeding here in autumn; in England these instances are more common. The nest is usually placed in the most solitary recesses of the marsh or bog, amidst coarse grass, reeds, and rushes; and generally contains from twelve to sixteen eggs, of a dull greenish-white. The young are led about by the mother in the same manner as those of the tame Duck, but with a superior caution, cunning, and watchful vigilance, peculiar to her situation.

"The male attaches himself to one female, as among other birds in their native state, and is the guardian and protector of her and her feeble brood. The Mallard is numerous in the rice fields of the Southern States during winter; many of the fields being covered with a few inches of water, and the scattered grains of the former harvest lying in abundance, the Ducks swim about and feed at pleasure. The flesh of the commor Wild Duck is in general and high estimation, and the ingenuity of man, in every country where it frequents, has been employed in inventing stratagems to overreach these wary birds, and procure a delicacy for the table. To enumerate all these various contrivances would far exceed our limits; a few, however, of the most simple and effective may be mentioned. In some ponds frequented by these birds, five or six wooden figures are painted so as to represent ducks, and sunk by pieces of lead nailed on the bottoms, so as to float at the usual depth on the surface, are anchored in a favorable position for being raked from a concealment of brush, etc., on shore. The appearance of these usually attracts passing flocks, which alight, and are shot down. Sometimes eight or ten of these painted wooden 
ducks are fixed on a frame, in various swimming postures, and secured to the bow of the gunner's skiff, projecting before it in such a manner that the weight of the frame sinks the figures to the proper depth; the skiff is then dressed with sedge or coarse grass, in an artful manner, as low as the water's edge, and under cover of this, which appears like a party of Ducks swimming by a small island, the gunner floats down, sometimes to the very skirts of a whole congregated multitude, and pours in a destructive and repeated fire of shot among them.

"In winter, when detached pieces of ice are occasionally floating in the river, some of the gunners on the Delaware paint their whole skiff, or canoe, white; and laying themselves flat at the bottom, with the hand on the side, silently managing a small paddle, direct it imperctptibly into or near a flock, before the Ducks have distinguished it from a floating mass of ice, and generally do great execution among them. A whole flock has sometimes been thus surprised asleep, with their heads under their wings.

"On land, another stratagem is sometimes practised with great success. A large, tight hogshead is sunk in the flat marsh or mud, near the place where Ducks are accustomed to feed at low water, and where, otherwise, there is no shelter; the edges and top are carefully concealed with tufts of long, coarse grass, and reeds or sedges. From within this, the gunner, unseen and unsuspected, watches his collecting prey; and when a sufficient number offers, sweeps them down with great effect.

"The mode of catching Wild Ducks, as practised in India and China, the island of Ceylon, and some parts of South America, has been often described, and seems; if reliance may be placed on those accounts, only practicable in water of a certain depth. The sportsman, covering his head with a hollow wooden vessel or calabash, pierced with holes to see through, wades into the water, keeping his head only above, and thus disguised, moves in among the flock, which takes the appearance to be a mere floating calabash, while suddenly pulling them under by the legs, he fastens them to his girdle, and thus takes as 
many as he can conveniently stow away, without in the least alarming the rest. They are also taken with snares made of horsehair, or with hooks baited with small pieces of sheep's lights, which, floating on the surface, are swallowed by the Ducks, and with them the hooks. They are also approached under cover of a stalking horse, or a figure formed of thin boards, or other proper materials, and painted so as to represent a horse or an ox.

"But all these methods require much watching, toil, and fatigue; and their success is but trifling when compared with that of the decoys now used both in France and England; which, from its superiority over every other mode, is well deserving the attention of persons of this country residing in the neighborhood of extensive marshes frequented by Wild Ducks, as by this method Mallard and other kinds may be taken by thousands at a time."-Wilson's Am. Ornithology.

Next in size, though neither in beauty nor in excellence, to the Mallard, comes the Dusky Duck, better known in every part of the United States as the Black Duck, the latter being a misnomer as applied to this fowl, and really belonging to a very different bird, which will be treated of hereafter with the Sea Ducks-Fuligula. This bird, unlike the former species, which is common to both continents, Europe and America, if not to Africa and Asia also, is peculiar to North America, ranging from Labrador to Texas; in both of which, strange to say, and in all the intermediate localities, it breeds and rears its young.

\section{THE DUSKY DUCK.}

Anas Obscura-Wilson, Bonap. The Black Duck.

"Breeds in Texas, westward, and throughout the United States, British Provinces, Labrador, and Columbia River 
Common in autumn and spring along the middle Atlantic districts. Abundant in the Southern and Western States in winter.

"Adult male.

"Bill about the length of the head, higher than broad at the base, depressed and widened toward the end, rounded at the tip. Upper mandible with the dorsal line sloping and a little concave, the ridge at the base broad and flat, toward the end broadly convex, as are the sides; the edges soft and thin, the marginal lamellæ about forty on each side. The unguis obovate, curved, abrupt at the end. Nasal groove sub-basal, elliptical, filled with the soft membrane of the bill; nostrils sub-basal, placed near the ridge, longitudinal, elliptical, pervious. Lower mandible slightly curved upward, flattened, with the angle very long, narrow, and rather pointed ; the lamellæ about sixty.

"Head of moderate size, oblong, compressed. Neck rather long and slender. Body full, depressed. Feet short, stout, placed a little behind the centre of the body. Legs bare a little above the joint. Tarsus short, a little compressed, anteriorly with small scutella, externally of which is a series continuous with those of the outer toe, laterally and behind with reticulated angular scales. Hind toe extremely small, with a very narrow membrane; third toe longest, fourth a little shorter, but longer than the second; the scutella of the second and third oblique, of the outer transverse; the three anterior toes connected by reticulated membranes, the outer with a thick margin, the inner with a margin extended into a slightly lobed web. Claws small, arched, compressed, rather obtuse, that of the middle toe much larger, with a dilated thin edge.

"Plumage dense, soft, elastic ; on the neck and head the feathers linear-oblong, on the other parts, broad and rounded. Wings of moderate breadth and length, acute ; primaries narrow and tapering, the second longest, the first very little shorter; secondaries broad, curved inward ; the inner elongated and tapering. Tail short, much rounded, of eighteen acute feathers, none of which are recurved.

"Bill yelluwish-green, the unguis dusky. Iris dark brown. vol. 1 . 
Feet orange-red, the webs dusky. The upper part of the he is glossy brownish-black, the feathers margined with light brown; the sides of the head and a band over the eye are light grayish-brown, with longitudinal dusky streaks; the middle of the neck is similar, but more dusky. The general color is blackish-brown, a little paler beneath; all the feathers margined with pale, reddish-brown. The wing coverts are grayish dusky, with a slight tinge of green; the ends of the secondary coverts velvet-black. Primaries and their coverts blackish-brown, with the shafts brown; secondaries darker; the speculum is green, blue, violet, or amethyst-purple, according to the light in which it is viewed, bounded by velvet-black; the feathers also tipped with a narrow line of white. The whole under surface of the wing and the axillaries, white.

"Length to the end of tail, $24 \frac{1}{2}$ inches; to the end of claws, 26 ; extent of wings, $38 \frac{1}{2}$; bill, $2 \frac{4}{12}$ along the back ; wing from flexure, $11 \frac{1}{2}$; tail, $4 \frac{4}{12}$; tarsus, $1 \frac{13}{2}$; middle toe, $2 \frac{3}{12}$; first toe, $\frac{5}{12}$; its claw, $\frac{2}{12}$; weight, 3lbs.

" Adult female.

"The female, which is somewhat smaller, resembles the male in color, but is more brown, and has the speculum of the same tints, but without the white terminal line.

"Length to the end of tail, 22 inches; to the end of wings, $21 \frac{1}{4}$; to the end of claws, 22 ; wing from flexure, $10 \frac{1}{2}$; extent of wings, $34 \frac{1}{4}$; tarsus, 2 ; middle toe and claw, $2 \frac{1}{2}$; hind toe and claw, $\frac{5}{12}$.

"This species extends its migrations from the Straits of Belleisle, on the coast of Labrador, to Texas. Strange as it may seem, it breeds in both of these countries, and in many of the intermediate places. On the 10th of May, 1833, I found it breeding along the marshy edges of the inland pools, near the Bay of Fundy; and on Whitehead Island, in the same bay, saw several young birds of the same species, which, although apparently not a week old, were extremely active, both on land and water. On the 30th of April, 1837, my son discorered a nest on Galveston Island, in Texas. It was formed of grass and 
feathers : the eggs, eight in number, lying on the former, surrounded with the down and some feathers of the bird to the height of about three inches. The internal diameter of the nest was about six inches, and its walls were nearly three in thickness. The female was sitting, but flew off in silence as he approached. The situation was a clump of tall, slender grass, on a rather sandy ridge, more than a hundred yards from the nearest water, but surrounded by partially dried salt marshes. On the same island, in the course of several successive days, we saw many of these Ducks, which, by their actions, showed that they also had nests. I may here state my belief, that the Gadwall, Blue-winged Teal, Green-winged Teal, American Widgeon and Spoon-billed Duck, all breed in that country, as I observed them there late in Nay, when they were evidently paired. How far this fact may harmonize with the theories of writers respecting the migration of birds in general, is more than I can at present stop to consider. I have found the Black Ducks breeding on lakes near the Mississippi, as far up as to its confluence with the Ohio, as well as in Pennsylvania and New Jersey; and every one acquainted with its habits will tell you that it rears its young in all the Eastern States intervening between that last mentioned and the St. Lawrence. It is even found on the Columbia River, and on the streams of the Rocky Mountains; but as Dr. Richardson has not mentioned his having observed it in Hudson's Bay, or farther north, we may suppose that it does not risit those countries.

"As many of the nests found in Labrador differed from the one mentioned above, I will give you an account of them :-In several instances, we found them imberlded in the deep moss, at the distance of a few feet, or a few yards from the water; they were composed of a great quantity of dry grass and other vegetable substances; and the eggs were always placed directly on this bed, without the intervention of the down and feathers, which, however, surrounded them, and which, as I observed, the bird always uses to cover them, when she is about to leave them for a time. The eggs are two inches and a quarter in 
length, one inch and five-eighths in breadth, shaped like those of a domestic fowl, with a smooth surface, and of a uniform yellowish-white color, like that of ivory tarnished by long exposure. The young, like those of the Mallard, acquire the full beauty of their spring plumage before the season of reproduction commences, but exhibit none of the curious changes which that species undergo.

"Although the Dusky Duck is often seen on salt water bays or inlets, it resembles the Mallard in its habits, being fond of swampy marshes, rice fields, and the shady margins of our rivers, during the whole of its stay in such portions of the Southern States as it is known to breed in. They are equally voracious, and may sometimes be seen with their crops so protruded as to destroy the natural elegance of their form. When on the water, they obtain their food by immersing their head and neck in the water, and, like the Mallard, sift the produce of muddy pools. Like that species also, they will descend in a spiral manner from on high, to alight under an oak or a beech, where they have discovered the mast to be abundant.

" The flight of this Duck is powerful, rapid, and as sustained as that of the Mallard. While travelling by day, they may be distinguished from that species by the whiteness of their lower wing-coverts, which form a strong contrast to the deep tints of the rest of the plumage. Their progress through the air, when at full speed, must, I think, be at the rate of more than a mile in a minute, or about seventy miles an hour. When about to alight, they descend with double rapidity, causing a strong, rustling sound by the weight of their compact bodies and the rapid movements of their pointed wings. When alarmed by a shot or otherwise, they rise off their feet by a powerful single spring, fly directly upwards for eight or ten yards, and then proceed in a straight line.

" The Black Ducks generally appear in the Sound of Long Island in September or October, but, in very cold weather, proceed Southward; while those which breed in Texas, as I have been informed, remain there all the year. At their arrival they 
betake therriselves to the fresh-water ponds, and soon become fat, when they afford excellent eating; but when the ponds are covered with ice, they betake themselves to estuaries or inlets of the sea, and their flesh becomes less juicy, and assumes a fishy flavor. During continued frost, they collect into larger bodies than at any other time- - a flock once alighted seeming to attract others, until at last hundreds of them meet, especially in the dawn and toward sunset. The larger the flock, however, the more difficult it is to approach it, for many sentinels are seen on the lookout, while the rest are asleep or feeding along the shores. Unlike the Sea Ducks, this species does not ride at anchor, as it were, during its hours of repose."-Audubon's Birds of America.

THE BLUE-WINGED TEAL.

Anas Discors.

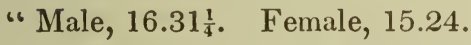

"Breeds in Texas and Westward, Great Lakes, Fur Countries, Columbia River. Very abundant in autumn and spring in the Middle Atlantic Districts, as well as in the interior. Abundant also in all the Southern States.

"Adult Male.

"Bill almost as long as the head, deeper than broad at the base, depressed toward the end; its breadth nearly equal in its whole length, being, however, a little enlarged toward the rounded tip. Upper mandible with the dorsal outline at first sloping, then nearly straight, on the unguis decurved, the ridge broad and flat at the base, suddenly narrowed over the nostrils, broader and convex toward the end ; the sides erect at the base, afterward sloping and convex; the narrow membranous margins a little broader at the end. Nostrils sub-basal, near the ridge, rather small, elliptical, pervious. Lower mandible flattened, straight, with the angle very long and rather narrow, the 
dorsal line very short and slightly convex, the sides internally erect, with about a hundred and twenty lamellæ.

"Head of a moderate size, oblong, compressed. Neck of moderate length, rather slender. Body full, depressed. Feet short, placed rather far back. Tarsus short, compressed at its lower part, anteriorly with two series of scutella, the rest covered with reticulated angular scales. Toes with numerous scutella above. First toe very small, and with a narrow membrane beneath; third longest; fourth about a quarter of an inch shorter; the anterior toes united by reticulated webs, of which the outer is deeply sinuate. Claws small, curved, compressed, acute; the hind one smaller and more curved, that of the third toe largest, and with the inner margin sharp.

"Plumage dense, soft and blended. Feathers of the head and neck very small and slender-of the back and lower parts in general, broad and rounded. Wings of moderate length, rather narrow and acute; primaries strong, slightly curved, tapering; the first scarcely longer than the second, the rest rapidly decreasing; secondaries broad, the outer obliquely rounded, the inner elongated and acuminate, as are the scapulars. Tail short, rounded and acuminate, of fourteen rather narrow acuminate feathers.

"Bill bluish-black. Iris dark hazel. Feet dull yellow; webs dusky. Claws brownish-black, with the tips grayish-yellow. Upper part of the head black; a semilunar patch of pure white on the side of the head before the eye, margined before and behind with black. The rest of the head, and the anterior parts of the neck, of a deep purplish-blue, with purplish-red reflections ; the lower hind neck and fore-part of back brownishblack, glossed with green, each feather with a curved band of pale reddish-buff, and a line or band of the same in the centre; the hind part of the back greenish-brown, the feathers edged with paler. The smaller wing-coverts of a rich ultra-marine blue, silky, with almost metallic lustre. Alula, primary coverts and primary quills, grayish-brown, edged with pale bluish; outer secondaries of the same color, those of the speculum duck- 
green, changing to blue and bronze, with a narrow line of white along their terminal margin; the inner greenish-black on the outer web, greenish-brown on the inner, with a central line and narrow external margin of pale reddish-buff; the more elongated scapulars similar, but some of them margined with greenishblue. Secondary coverts brown, with their terminal portion white. Tail feathers chocolate-brown, slightly glossed with green; their margins buffy. The lower parts are pale reddishorange, shaded on the breast with purplish-red, and thickly spotted with black, the number of roundish or elliptical spots on each feather varying from ten to twenty-five ; those on the upper and hind parts of the sides running into transverse bars. Axillary feathers, some of the lower wing-coverts, and a patch on the side of the rump, pure white; lower tail coverts brownish-black.

"Length to end of tail, 16 inches ; to end of claws, $14 \frac{1}{4}$; to end of wings, $14_{4}^{1}$; extent of wings, $31 \frac{1}{4}$; wing from flexure, $7 \frac{4}{12}$; tail, $3 \frac{5}{12}$; bill along the back, $1 \frac{1}{4}$; from frontal process to tip, $1 \frac{1}{2}$; tarsus, $1 \frac{2}{12}$; first toe and claw, $\frac{5}{12} ;$ middle toe and claw, $1 \frac{10}{12}$; outer toe and claw, $1 \frac{8}{12}$; weight, $12 \frac{1}{2} \mathrm{oz}$.

" Adult Female.

"Bill greenish-dusky. Iris hazel. Feet of a duller yellow than those of female; the head and neck are pale, dull buff, longitudinally marked with brownish-black lines, which are broader and darker on the top of the head; the fore-parts of the cheek and the throat whitish, without markings. The upper parts are dark brown, the feathers margined with brownish-white. The smaller wing-coverts colored as in the male, but less brilliantly; no blue on the scapulars, which are also less elongated. On the lower parts, the feathers are dusky-brown, broadly margined with light brownish-gray, of which there is a streak or spot in the centre. The axillary feathers, and some of the lower wingcoverts are white, but the patch of that color, so conspicuous in the male, is wanting.

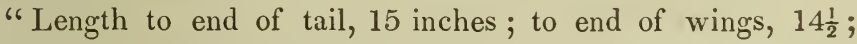
to end of claws, $15 \frac{1}{2}$; extent of wings, 24 ; wing from flexure, $7 \frac{1}{4}$; tail, $2 \frac{7}{12}$; bill along the ridge, $2 \frac{2}{\frac{2}{2}}$; weight, $10 \frac{1}{2} \mathrm{oz}$. 
"The young birds are similar to the female, but paler, and without the speculum."-Audubon's Birds of America.

"The Blue-Winged Teal is the first of its tribe that returns to us in the autumn from its breeding-place in the North. They are usually seen early in September along the shores of the Delaware, where they sit on the mud, close to the edge of the water, so crowded together, that the gunners often kill great numbers at a single discharge. When a flock is discovered thus sitting and sunning themselves, the experienced gunner runs his bateau ashore at some distance above or below them, and, getting out, pushes her before him over the slippery mud, concealing himself all the while behind her. By this method he can sometimes approach within twenty yards of the flock, among which he generally makes great slaughter. They fly rapidly, and when they alight, drop down suddenly, like the Snipe or Woodcock, among the reeds or on the mud. They feed chiefly on vegetable food, and are eagerly fond of the seeds of the reeds or wild oats. Their flesh is excellent, and after their residence for a short time among the reeds, they become very fat. As the first frosts come on, they proceed to the South, being a delicate bird, very susceptible of cold. They abound in the inundated rice field: of the Southern States, where vast numbers are taken in traps, placed on small dry eminences, that here and there rise above the water. These places are strewed with rice, and by the common contrivance called a figure four they are caught alive in hollow traps. In the month of April they pass through Pennsylvania for the North, but make little stay at that season. I have observed them numerous on the Hudson, opposite to the Katskill Mountains. They rarely visit the sea shore."-Wilson's Am. Ornithology.

The Blue-Winged Teal is stated to be very easily tamed, and very docile in confinement. It is strange that this bird and the Wood Duck are not both domesticated. 


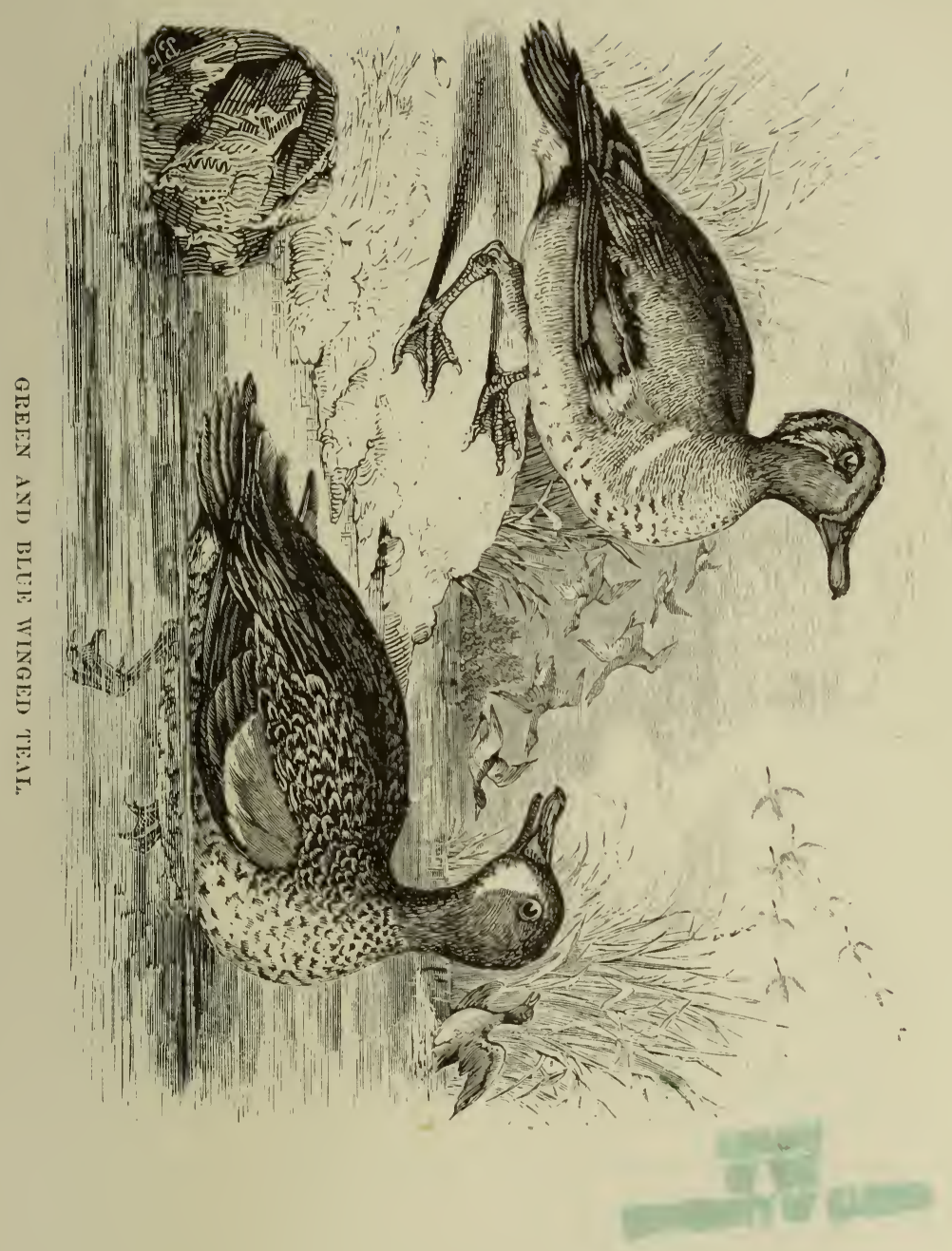





\section{THE GREEN-WINGED TEAL.}

\section{Anas Crecca, sive, Carolinensis.}

" Male, 14 $\frac{3}{4} \cdot 24$. Female, $13_{4}^{3} \cdot 22 \frac{1}{2}$.

"Dispersed throughout the country during autumn and spring. Extremely abundant during winter in all the Southern States and Texas. Breeds sparingly along the Great Lakes, and far North.

" Adult Male.

"Bill almost as long as the head, deeper than broad at the base, depressed toward the end, its breadth nearly equal in its whole length, being, however, a little enlarged toward the rounded tip. Upper mandible with the dorsal line at first sloping, then concave, toward the ends nearly straight, the ridge broad and flat at the base, then broadly convex, the sides convex, the edges soft, with about fifty-five lamellæ. Nostrils sub-basal, near the ridge rather small, elliptical, pervious. Lower mandible flattish, with the angle very long and rather narrow. The dorsal line very short, straight, the sides perpendicular, with about a hundred and thirty lamellæ.

" Head of moderate size, compressed. Neck of moderate length, rather slender. Body full, depressed. Wings rather small. Feet short, placed rather far back. Tarsus short, compressed at its lower part, anteriorly with two series of scutella, the rest covered with reticulated angular scales. Toes scutel late above; first toe very small, free, with a narrow membrane beneath; third longest, fourth a little shorter; the anterior toes connected by reticulated webs, of which the outer is deeply sinuate. Claws small, curved, compressed, acute; the hind one smaller and more curved; that of the third toe largest, and with an inner sharp edge.

" Plumage dense, soft, blended. Feathers of the middle of the head and upper part of hind neck very narrow, elongated, with soft, filamentous, disunited bands; of the rest of the head 
and upper parts of neck very short; of the back and lower parts in general, broad and rounded. Wings of moderate length, narrow, acute. Primaries strong, curved, tapering; second longest; first scarcely shorter; secondaries broad, rather pointed, the inner elongated and tapering, as are the scapulars. Tail short, rounded and acuminate, of sixteen acuminate feathers.

" Bill black. Iris brown. Feet light bluish-gray. Head and upper part of the neck chestnut-brown; a broad band narrowing backward from the eye down the back of the neck, deep, shining green, edged with black below ; under which is a white line, which, before the eye, meets another that curves forward and downward to the angles of the mouth. Chin brownish-black, as are the feathers at the base of the upper mandible. Upper parts and flanks beautifully undulated with narrow, brownish-black and white bars; anterior to the wings is a short, broad, transverse band of white. Wings brownish-gray; the speculum in the lower half violet-black, the upper bright green, changing to purple, and edged with black; behind margined with white, before with reddish-white. Tail brownish-gray, the feathers margined with paler; the upper coverts brownish-black, edged with light yellowish-gray. Lower part of neck anteriorly barred as behind. Breast yellowish-white, spotted with black; its lower part white. Abdomen white, faintly barred with gray. A patch of black under the tail; the lateral tail-coverts creamcolored, the larger black, with broad white margins and tips.

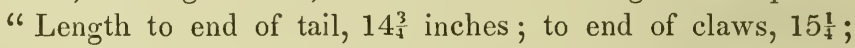
extent of wings, 24; wing from flexure, $7 \frac{1}{2}$; tail, $3 \frac{1}{4}$; bill along the back, $1 \frac{7}{12}$; along the edge of lower mandible, $1 \frac{9}{12}$; tarsus, $1 \frac{2}{12}$; middle toe, $1 \frac{6}{12}$; its claw, $\frac{5}{12}$; weight, $10 \mathrm{oz}$.

"Adult female.

" The female wants the elongated crest, and differs greatly in coloring. The head and neck are streaked with dark brown and light red; the foreneck whitish; the upper parts mottled with dark brown; the anterior feathers barred, the posteriors margined with yellowish-white. The wings are nearly as in the male, but the green of the speculum is less extensive; the 
lower part of the foreneck is tinged with yellowish-red, and mottled with dark brown, as are the sides; the rest of the lower parts white.

"Length to end of tail, $13_{4}^{3}$; to end of claws, $14 \frac{1}{4}$; extent of wings, $22 \frac{1}{2}$; weight, 10oz."-Audubon's Birds of America.

" Most writers on the ornithology of America have considered this bird as a variety of the European Teal. All, however, agree in their regarding the difference in the variety, and of its being constant in the Northern specimens. Thus, Dr. I atham mentions the white pectoral band. Forster says, "This is a variety of the Teal, for it wants the two white streaks above and below the eyes; the lower one indeed is faintly expressed in the male, which has also a lunated bar of white over each shoulder; this is not to be found in the European Teal.' Pennant observes, 'that it wants the white line which the European one has above each eye, having only one below; has over each shoulder a lunated bar.' The authors of the Northern Zoology observe, "The only permanent difference that we have been able to detect, after comparing a number of specimens, is that the English Teal has a white longitudinal band on the scapulars, which the other wants. All the specimens brought home by the Expedition have a broad transverse bar on the shoulder, which does not exist in the English one.' And our author in his plate, has most distinctly marked the differences. From the testimony of all its describers, marking the variety as permanent and similar, I am certainly inclined to consider this bird, though nearly allied, to be distinct; and as far as we yet know, peculiar to the Northern parts of America. I have not been able to procure a specimen for immediate comparison, and only once had an opportunity of slightly examining a Northern bird. From their great similarity no observers have yet particularly attended to the manners of the American bird, or to the markings of the females. If the above observations are the means of directing farther attention to these points, they will have per- 
formed their intended end. I by no means consider the point decided.

"The naturalists of Europe have designated this little Duck by the name of American Teal, as being a species different from their own. On an examination, however, of the figure and description of the European Teal, by the ingenious and accurate Bewick, and comparing them with the present, no difference whatever appears in the length, extent, color, or markings of either but what commonly occurs among individuals of any other tribe; both undoubtedly belong to one and the same species.

"This, like the preceding, is a fresh water Duck, common in our markets in autumn and winter, but rarely seen here in summer. It frequents ponds, marshes, and the reedy shores of creeks and rivers; is very abundant among the rice plantations of the Southern States; flies in small parties, and feeds at night; associates often with the Duck and Mallard, feeding on the seeds of various kinds of grasses and water plants, and also on the tender leaves of vegetables. Its flesh is accounted excellent."-Wilson's Ornithological Biography.

I have myself repeatedly shot this bird on both continents, and am now thoroughly convinced that the two species are permanently and invariably distinct. In my first edition I'recorded a contrary opinion, but subsequent examination of many specimens has led to a correcter judgment. The transverse lunated bar on the shoulder of the American species, as exhibited in the accompanying cut, is the distinctive mark, and I am not sure but that our bird is somewhat the larger.

\section{THE WOOD DUCK-SUMMER DUCK.}

Anas Sponsa.

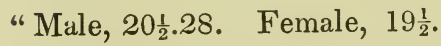

" Breeds throughout the country from Texas to the Colum- 
bia, and Eastward to Nova Scotia ; Fur Countries. Accumulates in the Southern Districts in winter.

" Adult male.

"Bill shorter than the head, deeper than broad at the base, depressed toward the end, slightly narrowed toward the middle of the unguis, the frontal angles prolonged and pointed. Upper mandible with the dorsal line at first sloping, then concave, along the unguis convex, the ridge broad and flat at the base, convex and sloping toward the end, edges soft with about twenty-two lamellæ, unguis broadly elliptical, curved, rounded Nostrils sub-basal, lateral, rather small, oval, pervious. Lower mandible flattish, with the angle very long and rather narrow, the dorsal line very short, convex, the sides convex, the edges soft and rounded, lamellate above.

"Head of moderate size. Neck rather long and slender. Body full and depressed. Wings rather small. Feet very short, strong, placed rather far back; tarsus very short, considerably depressed, at its lower part anteriorly with two series of scutella, the rest covered with reticulated angular scales. Toes scutellate above; first very small, free, with a narrow membrane beneath; third longest, fourth a little shorter ; claws small, curved, compressed, acute; the hind one smaller and more curved, that of the third toe with an inner sharp edge.

"Plumage dense, soft, blended, generally glossed. Feathers of the middle of the head and upper part of the hind neck very narrow, elongated, and uncurved; of the rest of the head and upper part of the neck very short; of the back and lower parts in general broad and rounded, excepting on the shoulders before the wings, where they are enlarged, very broad and abrupt. Wings of moderate length, narrow, acute; primaries curved, strong, tapering, first and second longest; secondaries broad and rounded. Tail of moderate length, rather broad, much rounded, of sixteen rounded feathers.

"Upper mandible bright red at the base, yellowish at the sides; the intermediate space along the ridge and the unguis black, as in the lower mandible and its membrane. Iris and 
edges of eye-lids bright red. Feet dull orange; claws black. Upper part of the head, and space between the bill and the eye, deep green and highly glossed; below the latter space a patch of dark purple, and a larger one of the same color, but lighter, behind the eye; sides of the neck, its hind parts under the crest and the middle all round very dark purple. A narrow line along the base of the upper mandible and over the eye, meeting on the occiput, very pure white, as are some of the feathers of the crest; another from behind the eye, meeting below the occiput, and including several of the lower elongated feathers. Throat for more than three inches pure white, with a process on each side a little beyond the eye, and another nearly half way down the throat. Sides of the neck, and its lower part anteriorly, reddish-purple, each feather on the latter with a triangular white tip. Middle of the neck behind, back and rump, very dark reddish-brown, the latter deeper and tinged with green; upper tail coverts and tail greenish-black; some of the lateral tail coverts dull reddish-purple, a few on either side with their filaments light red. Smaller wing coverts, alula, and primaries dull grayish-brown; most of the latter with part of their outer web grayish-white, and their inner toward the tip darker and glossed with green. Secondary quills tipped with white, the outer webs green, with purple reflections; those of the inner secondaries and scapulars velvet black, their inner webs partially glossed, and changing to green. The broad feathers anterior to the wings are white, terminated with black; breast and abdomen grayish-white; feathers under the wings yellowish-gray, minutely undulated with black and white bars; lower wing coverts and axillar features white, barred with grayish-brown; lower tail coverts dull grayish-brown.

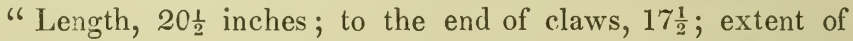
wings, 28 ; bill, $1 \frac{6}{12}$; tarsus, $1 \frac{5}{12}$; middle toe and claw, $2 \frac{3}{12}$; wing from flexure, 9 ; tail, $4 \frac{1}{4}$.

"Adult female.

" The female is considerably smaller, and differs greatly from the male in coloring. The feathers of the head are not elon- 
gated, but those of the upper part of the neck are slightly so. In other respects the plumage presents nothing very remarkable, and is similar to that of the male, only the feathers anterior to the wing, the hypochondrial, the inner secondaries and the rump feathers, are not enlarged as in him. Bill blackish-brown; feet dusky, tinged with yellow. Upper part of the head dusky, glossed with green; sides of the head and neck, and the hind part of the latter, light brownish-gray; throat white, but without the lateral processes of the male. Forepart of the neck below, and sides, light yellowish-brown, mottled with dark grayish-brown, as are the sides under the wings; breast and abdomen white, the former spotted with brown. Hind neck, back and rump, dark brown, glossed with green and purple Wings as in the male, but the speculum less, and the secondaries externally faint reddish-purple; the velvet black of the male diminished to a few narrow markings. Tail dark brown, glossed with green; lower tail-coverts pale grayish-brown, mottled with white; lower wing-coverts as in the male.

"Length, $19 \frac{1}{2}$ inches.

"This beautiful species ranges over the whole extent of the United States, and I have seen it in all parts from Louisiana to the confines of Maine, and from the vicinity of our Atlantic coasts as far inland as my travels have extended. It also occurs sparingly in the breeding season in Nova Scotia, but farther North I did not observe it. Everywhere in this immense tract, I have found it an almost constant resident, for some spend the winter even in Massachusetts, and far up the warm spring waters of brooks on the Missouri. It confines itself, however, entirely to fresh water, preferring at all times the secluded retreats of the ponds, bayous, or creeks, which occur so profusely in our woods.

"The flight of this species is remarkable for its speed, and for the ease and elegance with which it is performed. The Wood Duck passes through the woods, and even among the branches of trees, with as much facility as the Passenger Pigeon; and while removing from some secluded haunt to its breeding- 
grounds at the approach of night, it shoots over the trees like a meteor, scarcely emitting any sound frorn its wings.

"'The Wood Duck breeds in the Middle States about the beginning of April, in Massachusetts a month later, and in Nova Scotia, or our Northern Lakes, seldom before the first days of June. In Louisiana and Kentucky, where I have had better opportunities of studying their habits in this respect, they generally pair about the first of March, sometimes a fortnight earlier. I never knew one of these birds to form a nest on the ground, or on the branches of a tree; they always seem to prefer the hollow, broken portion of some large marsh, the hole of our large Woodpecker, Picus Principalis, or the deserted retreat of the fox squirrel; and I have frequently been surprised to see them go in and out of a hole of any one of these, when their bodies while on wing, seemed to be nearly half as large again as the aperture within which they had deposited their eggs. Once only I found a nest with ten eggs, in the fissure of a rock, on the Kentucky River, a few miles below Frankfort. The eggs, which are from six to fifteen, according to the age of the bird, are placed on dry plants, feathers, and a scanty portion of down, which I believe is mostly plucked from the breast of the female. They are perfectly smooth, nearly elliptical, of a light color between buff and pale green, two inches in length by one and a half in diameter; the shell is about equal in firmness to that of the Mallard's egg, and quite smooth.

"No sooner has the female completed her set of eggs than she is abandoned by her mate, who now joins others, which form themselves into considerable flocks, and thus remain until the young are able to fly, when old and young of both sexes come together, and so remain until the commencement of the next breeding season. If the nest is placed immediately over the water, the young, the moment they are hatched, scramble to the mouth of the hole, launch into the air with their little wings and feet spread out, and drop into their favorite element; but whenever their birth-place is at some distance from it, the 
mother carries thein to it, one by one, in her bill, holding them so as not to injure their yet tender frames.

"Those which breed in Maine, New Brunswick, and Nova Scotia, move southward as soon as the frosts commence, and none are known to spend the winter so far North. I have been much surprised to find Wrusor speaking of the Wood Ducks as a species of which more than five or six individuals a:c seldom seen together. A would-be naturalist in America, who has had better opportunities of knowing its habits than the admired author of the 'American Ornithology,' repeats the same error; and I am told, believes that all his statements are considered true. For my own part, I have seen hundreds in a single flock, and have known fifteen to be killed by a single shot. They, however, raise only one brood in the course of the season, unless their eggs or young are destroyed. In this case the female soon finds means of recalling her mate from the flock which he has joined."-Audubon's Birds of America.

The discrepant statements, alluded to in the last paragraph, concerning the gregarious habits of the Wood Duck, may be probably accounted for by the difference of the bird's manners in different localities. I have never myself seen above eight or nine of these birds together, and I presume that along the Atlantic seaboard, they are rarely seen in greater numbers. On the Great Lakes, and in the unbounded solitudes of the West, they doubtless congregate, as do many other species, in vast flocks.

There is nothing which it behoves the observer of natural history more to guard against than a tendency to convert local or accidental peculiarities of individuals into settled habits of species. All wild animals appear to accommodate themselves with infinite facility to circumstances, and to adapt their manners to the necessities of the regions in which they chance to be thrown, more readily than is generally suspected. In one place, a species is solitary; in another, gregarious in its customs-here it is migratory, there domestic; and to positive and 
general dicta, ascribing these habits invariably to this or that species, much confusion and inconvenience may be attributed.

As an instance, I will merely state here, what I shall go into more largely hereafter, that the common Quail, Ortyx Virginia$n a$, which is to the Westward distinctly a bird of passage, with easily defined habits of migration, eastward of the Delaware River is unquestionably stationary; and that from this undoubted fact, a question has arisen whether there were not two different species; and, that hypothesis proved untenable. a doubt, among the less enlightened of Eastern sportsmen, whether the naturalists and travellers who have insisted on the migratory habits of the Quail, especially on the Ohio and other large western rivers, have not ignorantly or wilfully falsified the truth.

Such mistakes should be guarded against with care, and all conflicting statements, as made by candid and earnest enquirers, regarded with the utmost liberality and allowance; which, I regret to say, is too seldom practised by naturalists, who frequently appear to regard all who differ from themselves, much in the light of enemies, or of heretics, with whom no terms are to be kept.

The last water-fowl, of which I shall give a minute description as falling under the head of Upland Game, is the

\section{PINTAIL DUCK:}

Anas Acuta-Wilson. Le Canard a Longue Queue-Brissott. The Winter Duck, Sprigtail, Pigeontail, vulgo.

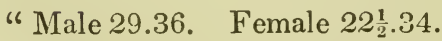

"From Texas throughout the interior to the Columbia River, and along the Atlantic coast to Maine, during the winter, and early spring. Breeds in the Arctic regions Abundant. 
"Bill nearly as long as the head, deeper than broad at the base, depressed toward the end, the frontal angles short and obtuse. Upper mandible with dorsal line at first sloping, then concave-toward the curved unguis nearly straight; the ridge broad and flat at the base, then broadly convex; the sides convex; the edges soft, with about fifty interual lamellx; unguis small, somewhat triangular, curved abruptly at the broad end. Nostrils sub-basal, lateral, rather sinall, oval, pervious. Lower mandible flattish, its angle very long and narrow; the dorsal line very short, slightly convex; the sides convex; the edges soft, with about fifty lamellæ.

" Head of moderate size, compressed, the forehead rounded. Neck rather long and slender. Body full and depressed. Wings rather small. Feet very short, placed rather far back; tarsus very short, compressed, at its lower part anteriorly with two series of scutella, the rest covered with reticulated scales. Toes obliquely scutellate above; first very small, free, with a narrow membrane beneath; third longest; fourth a little shorter, their connecting webs entire, reticulated, at the end pectinate. Claws small, curved, compressed, acute; the hind one smaller and more curved-that of the third toe with an inner sharp edge.

"Plumage dense, soft, blended. Feathers of the head and neck short; on the hind head and neck elongated. Wings narrow, of moderate length, acute; the first quill longest, the second nearly equal, the rest rapidly graduated; outer secondaries broad and rounded; inner elongated and tapering, as are their coverts and the scapulars; first quill serrated on the outer edge, something like that of the Owl. Tail of moderate length, tapering, of fourteen tapering feathers, of which the two middle project far beyond the rest.

"Bill black; the sides of the upper mandible light blue. Iris brown. Feet, grayish-blue. Claws black. Head, throat, and upper part of the neck anteriorly greenish-brown, faintly margined behind with purplish-red. A sinall part of hind neck dark-green; the rest, and the upper parts in general, beautifully 
undulated with very narrow bars of brownish-black and yellowish-white. Smaller wing-coverts, alula and primary quills graythe latter dark brown toward the end. Speculum of a copperyred, changing to dull green; edged anteriorly with light brownish-red; posteriorly with white. The inner secondaries and the scapulars black and green, with broad gray margins. Upper tail-coverts cream-colored, the outer webs blackish and green; tail light gray, the middle feathers dark brown, glossed with green. On each side of the neck is an oblique band of white, of which color are the under parts in general; the sides, however, are undulated like the back; the lateral feathers of the rump cream-colored; the lower tail-coverts black; those at the sides edged with white.

"Length to the end of tail, 29 inches ; extent of wings, 36 ; bill along the back, $2 \frac{2}{12}$; along the edge of lower mandible, $2 \frac{3}{12}$; tarsus, $1 \frac{8}{12}$; middle toe with claw, $2 \frac{4}{12}$; wing from flexure, 11 ; tail, $5 \frac{1}{2}$; weight 2 Ibs.

" Adult Female.

"The female, which is much smaller, has the upper parts variegated with brownish-black and light yellowish-brown; the margin of the feathers and a mark on each side of the shaft being of the latter color. The speculum is dusky green, margined behind with white. The primary quills grayish-brown. The lower parts are of a light brownish-yellow, the sides variegated with brown; the bill is black; the iris brown; the feet light bluish-gray.

"Length, $22 \frac{1}{2}$ inches ; extent of wings, 34 ; weight, 1lb. $9 \mathrm{oz}$. "The first observation that I made, on arriving at Labrador, was that no species of Ducks, excepting those which were entirely or chiefly oceanic, seemed to resort to that coast; and I left the country with the same impression. We saw no Mallards, Teals, Widgeons, or Wood Ducks there, nor any species of Merganser, except the Red-breasted, which is a marine bird. The Pintail Duck, then, was not known in the parts of that country which I visited; nor was it known in Newfoundland, on the Magdeleine Islands, or in the British Province of Nova 
scoria, at least along its Atlantic boundaries. In Kentucky, and the whole of the Western country, where it is extremely abundant in early autumn, during winter, and up to a very advanced period in spring, you meet with it wherever its usual food is to he found. It follows the waters of the Mississippi to New Orleans, is seen westward in the prairies of Oppelousas, and extends to the eastward as far as Massachusetts, beyond which, like the Mallard, it is very rarely seen. Indeed, this species is at all times rare on the seacoast of the Atlantic, and must therefore be regarded as an inland bird.

"The Pintail, which, in the United States, is better known by the name of Sprigtail, arrives on the Western waters early in October, sometimes even in September; the period of its arrival depending on the state of the weather, or the appearance of other species with which it keeps company. Their plumage is in fine condition when they arrive; their tail feathers are then as long as at any other period, and the whole apparel of the adult bird is as perfect as in the breeding season.

"Whilst with us, the Pintail is found in company with the Baldpate or American Widgeon, the Blue-Winged Teal, and the Mallard; more frequently on ponds than on streams; although it sometimes resorts to the latter, when their shores are overhung with beech-trees, loaded with their nutritious fruits, of which this species is extremely fond, and in search of which they even ramble a short distance into the woods. Were this Duck to feed entirely on beech mast, I have no doubt that its flesh would be excellent. It feeds on tadpoles in spring, on leecnes in autumn; while, during the winter, a dead mouse, should it come in its way, is swallowed with as much avidity as by a Mallard. To these articles of food it adds insects of all kinds ; and, in fact, is by no means an inexpert fly-catcher.

"The Pintails are less shy in the Western country than most species of their family; and in this respect they resemble the Blue-Winged Teals ; which, in fact, might be called stupid birds, with as much propriety as many others. They swim rather deeply, keep close together, and raise the hind part of the body' 
like the Mallards. On the water, on land, or on the wing sr. veral may generally be killed at a shot. They are scarcely nocturnal, but rest much in the middle of the day; basking in the sunshine whilst on the water, whenever they can indulge in this luxury.

" The flight of the Pintails is very rapid, groatly protracted, and almost noiseless. They remain at night in the ponds where they feed; and cuntinue there generally, unless much disturbed. On such occasions they keep in the middle of the water, to avoid their land enemies. In the Middle States they are highly esteemed for the table. There they arrive later, and retire sooner toward their breeding places, than in the country west of the Alleghany Mountains."-Audubon's Birds of America.

This species, like the last, is seldom found, in the northern part of the Middle and Eastern States, in such large flocks, as it would appear to use in the West. It is often found solitary; and very seldom, in my own experience, are more than three or four to be found in company.

I entertain some suspicion that the Pintail Duck occasionally breeds in New Jersey and in New York. In the former State, on one occasion, I shot an adult female bird, in full plumage, as late as the twelfth of May. She rose, before a dead point from an old setter, out of a thick tuft of alders on a large marsh meadow. I could find no traces of a nest, but can conceive no object but that of nidification which should have induced the bird to seek such a haunt. I have several times shot these birds during spring Snipe-shooting, so late as the end of April.

The American Widgeon, Anas Americana, is occasionally found on fresh waters, especially to the westward of the Ohio; but rarely frequents rivers, except on their estuaries and sandbars, where it associates more with the Fuligula, or Sea Ducks, than with its immediate congeners. It is found on the Chesapeake with the C'anvass-back, and is known as the "Bald pate." 
The Shoveller, Anas Clypeata, is rare in the United States; though they are found in Louisiana, Florida, and the Carolinas, in winter; but are abundant on the streams of the Rocky Mountains and in Texas.

The Gadwall, Anas Strepera, is also found, though rarely, along the maritime districts of the States. In the interior, especially on the tributaries of the Ohio, Missouri, and Mississippi, it is said to abound. It is of solitary habits, rarely congregating in large bodies, and is therefore not generally known in the United States.

Of the Sea Ducks, the Golden-Eye, Fuligula Clanyula, and the Buffel-Head, Fuligula Albeola, better known as the "Whistler," and the "Butter-Ball," are at times found on the fresh waters of the interior, but nut in sufficient numbers to render it necessary to do more than name them, as it would be a most liberal courtesy which should extend to them the style of Upland game, which may be held to be completed with the Duck last described.

The list thus concluded, the nomenclature established on fixed grounds, and the general habits and territorial limits of every kind of Upland game being thus laid before the reader, I shall proceed to treat, each in its several place and season, of the Upland shooting of the Eastern and Middle United States, and the Provinces, in all its various kinds and phases; touching upon each according to the date of its commencement in the natural year.*

* Since writing the above page, I ascertained, during two journeys through Canada, one along the northern shore of Lake Huron so far as to the Sault St. Marie, first, that "WIDGEON" are exceedingly abundant on the rivers and rice lakes of that region.

And secondly, that on Lake Champlain and on the St. Lawrence, about Prescott, the Golden Exe is the most numerous Duck, and that which affords most sport on those waters.

For the description of an excellent Duck, which I found very abundant on the upper lakes, and which I believe to be a nondescript, though the point is not quite decided, see Vol. II, Appendix F. 


\section{THE UPLAND SHOOTING}

OF THE

\section{EASTERN AND MIDDLE STATES, AND OF THE BRITISH PROVINCES.}

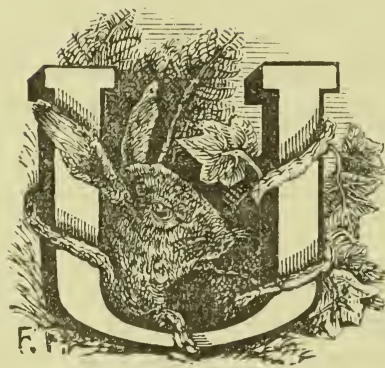

PLAND SHOOTING, which, with the interval of about three months in ordinary seasons, may be enjoyed in some form or other during the whole year, in the Eastern and Middle States, may be divided with propriety into four different heads, commencing with the opening of spring, and terminating only with the termination of the year.

These heads are "Spring Snipe Shooting;" "Summer Cock Shooting;" "Upland Plover Shooting;" and "Autumn Shooting," which might be called "general shooting," inasmuch as in the course of a good day's sport, it is by no means unusual to bring to bag almost every variety of game which I have enumerated above, the Grouse and the Northern Hare alone excepted.

A separate head must be given to Grouse shooting,-by which I mean Pinnated Grouse; since they are so nearly extinct in those districts in which alone Upland Shooting is practised scientifically and as a sport, that they are rarely, I might say never met with, by those in pursuit of other game.

It will be observed that I am now speaking of Upland shooting, as it is; both established by law, and habitually practised, 
in those of the States in which only game is generally protected by statute; not as I think it should be. For it is my settled opinion that Spring Snipe shooting and Simmer Cock shooting are both abominations; and that both humanity and policy forbid the slaughter of these birds of passage, until they have finished rearing their young, and until those young have attained their full growth. On this topic I shall enlarge hereafter, under the head of "Game Preservation;" though I have but slight hopes that any steps will be taken, which can avail to preserve all the winged gaine of America from speedy extermination. In like manner, I shall defer the observations, which I propose to make on the species, management, diseases, etc., of Sporting Dogs, and and on the qualities and management of the Fowlingpiece, and the art of shooting on the Wing, until I have got through what I have to say on Upland shooting generally.

And here I will remark, once for all, in reply to a question which has already been propounded to me several times, since it has transpired that I am engaged on this work-" Whether any portion of it will be set apart especially for the instruction of young sportsmen ?"-I am aware of nothing in the science of woodcraft more appropriate to be learned by the beginner, than another. There is no patent by which skill may be acquired, no formula to be learned, after which all is plain and easy sailing. So soon as any person has acquired the powes of bringing up his gun correctly on an object, and firing it at once without dwelling on his aim, he is fit to take the field; and after this, all the difference between the old and young, the good and had, sportsinan, natural qualifications which cannot be acquired alone excepted, is the amount of practice, and the extent of observation. He who most thoroughly understands the natural history, the instincts and the habits, both of the animals which he pursues and the animals which he uses as assistants in pursuit, will necessarily be the best sportsman; and all that the best sporting writer can accomplish is to give a small number of facts on which to work; and so to throw out many suggestions, which shall lead the sportsman into the habit of thinking for himself, 
and secing with his own eyes; and above all, cause him to avoid regarding the smallest peculiarity he may observe in the field of nature unworthy of consideration.

With regard to the art of shooting, a very few instructions only can be given, and they can do but little toward the formation of a shot. Practice alone can make a good shot, even of one endowed with the greatest natural aptitude; and, without the gift of natural aptitude, no one can ever hope to be a crack shot on the wing. No one, however, who desires it, need des pair of becoming, in something more than a moderate degree, a proficient in this beautiful art, since the introduction of the percussion system; which has so greatly simplified the art, and diminished the difficulty of shooting on the wing, that it is a current remark now-a-days that, "a bad shot in 1848 is a rarer thing to meet than a good one was in 1800."

The same thing is in a less degree the case with the management of $\operatorname{dog} s$ in the field; there are, it is true, general, aye, and particular rules, which may be laid down for the guidance of the hunter; which rules, if strenuously put in practice, shall be in themselves all sufficient. But to this end practice is essential-practice in learning when and how each rule is to be put in force; practice in controlling impatience, in combating temper, in acquiring perfect coolness and complete selfcommand. No man may hope, let him know how to do so never so well, to govern his dogs, until he has learned first to govern himself. If I were asked to state what were the three things most necessary to the formation of the perfect sportsman, I think I should parody the reply of the great Athenian rhetorician, and reply, " Practice! practice! practice!"

But of these things severally in their places: and now to the field for spring Snipe-shooting. 


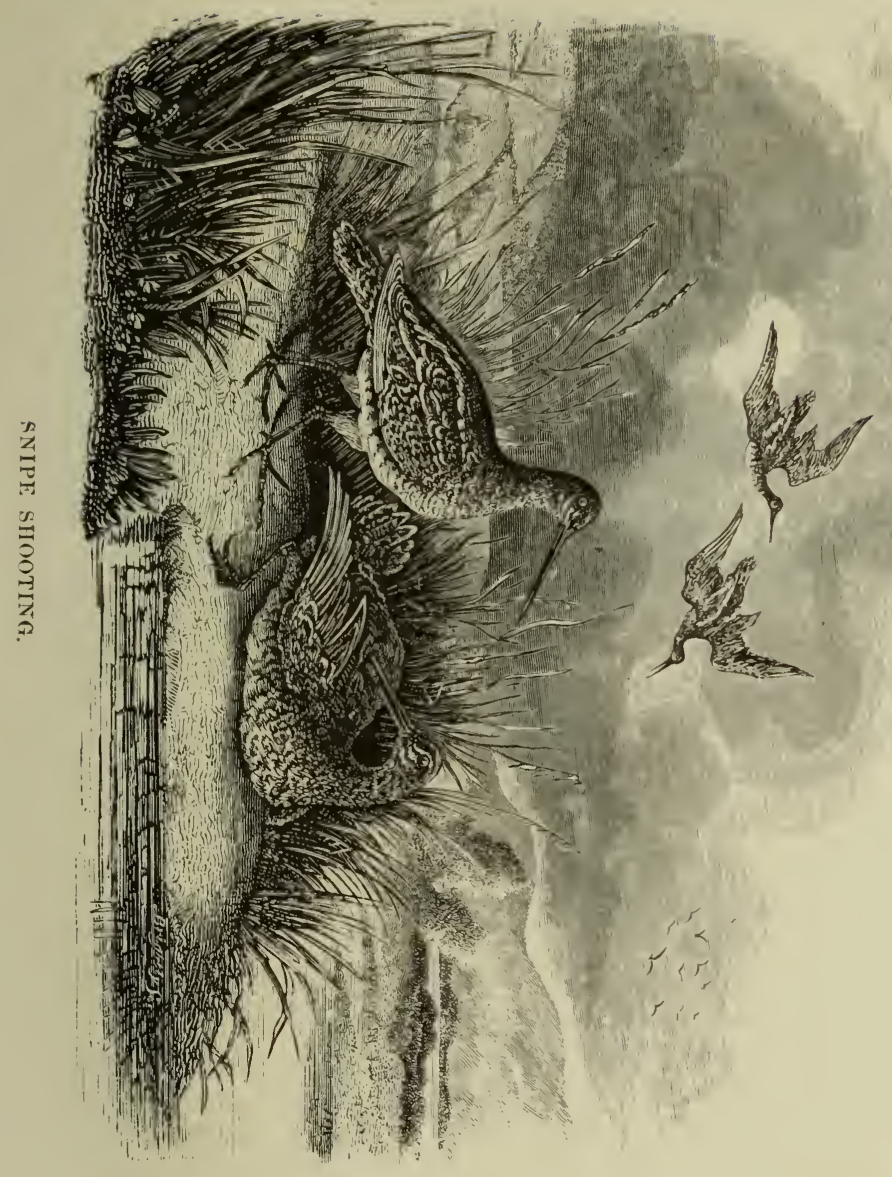





\section{SPRING SNIPE-SHOOTING.}

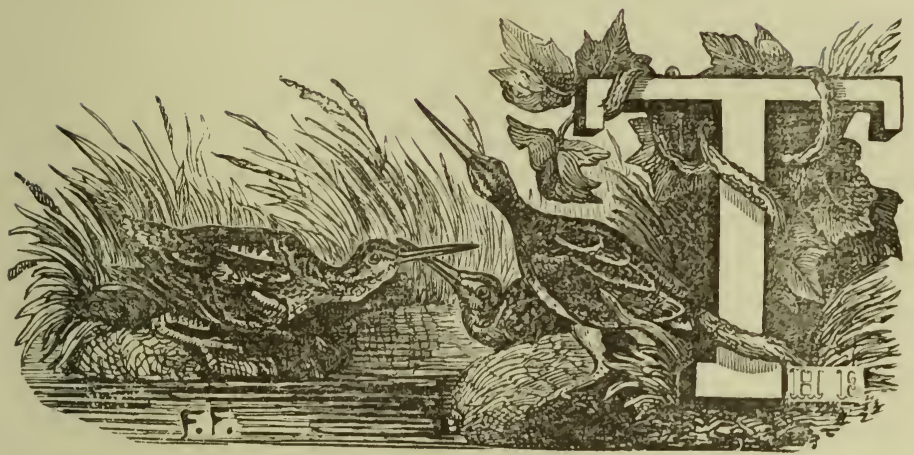

American Snipe,-Scolopax Wilsonii,-which is commonly known in this country as the English Snipe, but which is undoubtedly a distinct species, winters, as we have seen, in the Southern States, and yet southward of the most southern; being rarely found in the winter northward, or in the summer southward, of the Carolinas.

The great multitude breed far to the northward, not only of the United States, but of the British Provinces, in the vast marshy tracts which extend inland nearly to the Arctic Ocean. Many, however, make their nests and rear their young in the secluded morasses of Maine, Nova Scotia, and New Brunswick; and a few pairs, here and there throughout the Eastern and Middle States, becoming less frequent as they advance toward the South, so far probably as the north of Pennsylvania.

In Western Canada, in the neighborhood of Amherstberg, they are likewise found during the breeding seasun, and probably on the southern verge of the Great Lakes likewise.

They are, however, with us, from New Jersey eastward, essentially a spring and autumn passing visitant; and this is their character so far northward as Quebec. In New Brunswick and 
Nova Scotia they may perhaps be regarded as a summer resident; though I am persuaded that their numbers, even there, in the spring and autumn, will be found vastly to exceed the tale of those which remain and rear their young. Throughout the Southern and Western country they are, on the contrary, winter residents.

Now the shooting of these birds in spring, as they are either pairing here preparatory to breeding, or moving northward preparatory to pairing; or even actually breeding-as is the case when they are shot in May-is precisely what it would be to shoot Woodcock in February, March, and April, or Quail so late as to the middle of May; the destruction of the breeders, and consequent diminution of the number of the next year's young, being the same in both cases. The American Snipe lays four eggs; the death, therefore, of every Snipe during spring shooting is equivalent to the death of five of these beautiful and sporting little birds.

This, one would suppose, would be conclusive against the practice; but if he venture to break ground in favor of the abo lition by law of this unfair, and I must think, unsportsmanlike practice, he is met and silenced by some such exquisite reason as this-that if spring Snipe-shooting were prohibited, we should have no spring shooting at all; and the same exquisite reason is adduced against the only step which can save the Woodcock from extermination, I mean the abolition of summer cockshooting.

To return, however, to spring Snipe-shooting, as it is.

So soon as the spring is fairly broken, and the frost-to use a common phrase-entirely out of the ground, the Snipe begins to appear upon our meadows. This breaking of the spring, and disappearance of the subterranean frost is, as is well known, very uncertain as regards the time of its occurrence. Sometimes, particularly when the winter has been continuous and severe, spring comes upon us suddenly and remains permanentwith no cold squalls and nipping frosts intermediate-increasing still into perfect summer. At other times, nost frequently when 
the winter has been uncertain open and variable, and when the months of January and February have been, as was the case in 1843, unusually mild and genial, there is, as it were, no spring at all, winter lingering into the lap of June. In the year above mentioned, the ground was white with snow in Philadelphia on the first of that month.

In the former of these two kinds of spring, the Snipe compose themselves for a long sojourn, lie well to the dog, grow very fat and lazy, and defer their departure till the weather becomes so warm and dry as to render their migration a matter of necessity. As an example of this, in the spring of 1836 I drove from New York into Orange county, on the 10th of April, in a sleigh, over deep snow; and, within a week afterward, and thence up to the 10th of June, shot Snipe in abundance in New Jersey, both at Chatham and Pine Brook, on the Passaic.

In the latter there is sometimes no spring shooting at all; the birds merely alighting in whisps or small parties, from five to twenty in number, remaining a single day, and then off again Northward, with no tarrying.

For several years, latterly, spring Snipe-shooting has been so indifferent, that few sportsmen have followed it, and that the mar. kets have been badly supplied.

The arrival, however, of the Snipe in New Jersey-in Southern New York there is little good Snipe-ground-varies from the tenth of March, which is the earliest date at which $I$ have ever seen them plentiful on the Upland meadows, to the fifteenth of April. If they have not arrived at the latter of these dates, it may generally be taken for granted, that the year will have no pring Snipe-shooting.

It must be observed that obtaining great sport in spring snipeshooting must always, to those who do not reside immediately on the ground, be more or less a matter of good fortune; since it is not above once, in five or six years, that these birds come on and staj under such favorable circumstances, as cause them to settle, as it is termed, to the ground; and, when this is not the case, successive flights arriving, tarrying for a few days and passing onward, 
it is very possible that a stranger, coming from a distance to shoot, will find the meadows which were yesterday alive with Snipe, entirely deserted, and vice versa.

Still there are signs and tokens both of the weather and of the animal creation-temperatures of the former and coincidences of the latter-by which the observant sportsman may come at conclusions, even at a distance from his ground, and seldom erroneously, concerning the arrival and sojourn of Snipe.

And again, the birds have habits and haunts, during various aspects and sudden changes of weather, a thorough knowledge of which will enable one sportsman to fill his bag, while another on the same ground shall make up his mind in despair, that there are no Snipe on the meadows.

There is no bird whose habits I have studied more closely than those of the Snipe, more especially during his vernal visit to our part of the country, for which my residence, nearly adjoining the very finest Snipe-ground, as I believe it even yet to be, in the world, has given me great facilities; and I have it in my power to point out one or two peculiarities-tending, by the way, more completely to distinguish it from the European species-which have escaped the observation of our great American naturalists, Wilson and Audubon.

I have, moreover, shot them from Delaware southward, to Quebec, in the north; and from the Niagara River to the coun triy about the Penobscot; so that I have not been without oppor tunity of becoming acquainted in some degree with their habits, throughout the whole geographical area of their spring and autumn migration; and here I would state, though with much deference, as becomes one differing from so high an authority, that neither in this nor in any other of our migratory birds of Game is there so much difference with regard to the time of their arrival and departure within the limits I have named, as Mr. Audubon would make.

That eloquent writer and accurate observer, states the arrival of this bird to be a month later, varying with the season, in Maine than in Pennsylvania; and ten days later yet in Nova 
Scotia. Now I am satisfied that, unless when the winter is extremely short and spring unusually warm and early to the Westward, this discrepancy is greatly overrated.

The average commencement of Snipe-shooting, even in Delaware, is not earlier, I am convinced, than the first of April; and, except in uncommonly early seasons, they appear almost simultaneously in New Jersey and New York. Early in April, I have shot these birds in abundance close to the Falls of Niagara; early in April I have shot them in Maine; and at the end of that same month, I have shot them on the upland pastures around Quebec.

On average seasons, that is to say seasons in which the spring is everywhere late and backward, I have found by my own observation, that the arrival both of the Woodcock and of the Snipe is nearly simultaneous, from Pennsylvania to Maine, and I believe on enquiry such will prove to be the case.

This is, however, except as a inatter of curiosity, tending to throw light on the breeding seasons of our bird in various places, and so to enable us to legislate with most advantage for his preservation, a matter of small importance ; for, from the moment of his arrival in each several locality, until that of his departure, he is incessantly persecuted and pursued; and, as the causes of his arrival are the same in all places, so will, I apprehend, be the signs of his coming also.

The next observation that I would make in this place, is to guard the sportsman, in the United States and Canada, from placing the slightest reliance on the maxims, advice or opinims promulgated, even in the best sporting books published in Engand, concerning the Snipe, or its congener the Woodcock.

The birds are in every respect different from the European species, as to their habits, haunts and seasons; and one point of difference alone is sufficient to render all that is laid down with regard to the manner of hunting them there, entirely useless here. There they are winter, here more or less summer. birds of passage; so that the localities which they frequent in the two hemispheres are of course nearly opposite.

Not an English book but will tell you, and tell you truly, as 
regards the English Snipe, that the most favorable weather for the sport is dark, blowing, drizzling days-the very worst conceivable for our bird; which is apt to be as wild as a Hawk in windy weather, while it will sometimes lie till it is difficult to kick it up, on bright, warm, sunny days, with the wind southerly. But of this anon.

In the first place, observe, as regards the arrival of Snipe on the meadows, that it matters not how fair and mild and warm the weather may be, or may have been for many days, overhead, not a bird will be found until the subterranean fiost and ice have been entirely dissipated; which is rarely the case until after a three days' storm of rain, with a stiff easterly blow, succeeded by soft, spring-like weather.

It must here be remarked that, in morasses and bog meadows, whether fresh or salt, the underground frost lasts much longer unthawed than it does on the uplands. In one instance, I remember"finding all the meadows as hard as ice below some six inches of soft mud, when the frost had disappeared for many days on the uplands, and when the progress of spring was evident in the bursting buds and springing grass. Of course not a bird was to be found.

The first of the winged harbingers of spring is the beautiful little Blue-Bird; and so soon as he has taken up his residence with us, and commenced cleaning out his accustomed box, or preparing materials for his nest in the hole of a decayed apple-tree, we may be sure that the Snipe is not far distant. When the buds of the willow trees display their yellowish verdure, and the chirping croak of the frogs rises from every swampy pond, we may feel confident that he is to be found on the meadows; but not until the Shad is abundant at the mouths of our rivers, is the Snipe plentiful on the inland morasses.

On his first arrival, he generally hangs for two or three days in small whisps, or, oftener yet, scattered individually, along the salt meadows on the coast, especially in places where fresh springs boil up from the ground, or spring-brooks trickle down from the upland. 
At such times, a few straggling birds may be picked up on the south side of Long Island, where the trout-streams, below the pond-dams, overflow the salt meadows, before a solitary Snipe has appeared inland. Then the salt marshes about the mouths of the Raritan, the Hackensac, and the Passaic, attract them in turn for a few days; after which they gradually ascend the courses of those streams to the great tracts of morass and bog-meadow, which are spread out for leagues, the very Paradise of the Snipe-shooter, especially about the last-named river.

Here, if the weather is favorable and settled, they remain for many weeks; and may be pursued with much success and sport, by the skilful sportsman, whatever may be the nature of the day, unless it has been preceded by a very sharp frost.

The most favorable time is, undoubtedly, the first fine warm day after a long, easterly rain-storm; and, so thoroughly am I convinced of this fact, that for many seasons, while resident in New York, it was my habit to order my horses, and set out on the third day of a north-eastern storm, if the sky showed the slightest prospect of clearing, before the rain had in the least abated. It has more than once happened to me, thus setting off late in the evening, while it was yet raining, to see the sky gradially clear up, and to hear the shrill squeak of the Snipe travelling overhead faster than myself, though in the same direction, before reaching my shooting-ground, scarce twenty miles distant; and I have been amply rewarded for my trouble by an excellent and undisturbed day's sport, over meadows well stocked with birds, and as yet virgin of gunners.

In such cases, it will often, however, happen that the weather on the one or more days which can be spared for shooting, proves wild, windy and unfavorable; yet the sportsman who has travelled from a distance must take it as he finds it-if he reside on the spot he can, and of course will, pick his own days; which, if he be wise, will be those soft, moist, silvery mornings, which so often follow slight hoar-frosts, when the heaven is covered with the thinnest filmy haze, through which the sunbeams are poured down warm but mellow, and when there is just enough of low 
southerly wind abroad to dry the herbage and to give the dogs a chance of scenting their game.

As the stranger cannot thus choose, it is most important that he should know how to make the best of bad circumstances ; for even in the worst weather, if there be birds at all upon his range, knowing his ground and the habits of his bird, he will be able, nine times out of ten, to make a fair day's work.

I once shot three successive days over the Long Meadow, Lewises, the Troy and Parsippany Meadows, from Pine Brook, with a friend, in the very worst weather I ever saw for Snipeshooting-dry, keen, cutting north-easters, win the dust flying one half hour, and the sun shining clear but cold, and hailstones pelting down the next. The birds were, of csurse, as wild as can be imagined; drumming high up in the air, and performing all kinds of unusual antics; yet, by dint of good dogs, desperate fagging, and a perfect knowledge of our ground, we picked up sixty-two couple of Snipe, besides a few Duck, in the course of three days.

No great work, it is true, nor much to boast of ; but, mark me now-during those same three days, two other gentlemen, as good shots as ourselves, perhaps better, beat the same meadows, putting up at the rival tavern, and hunting so exactly the same line of country with ourselves, that we met and conversed with them more than once each day. These gentlemen bagged, in all, eleven Snipe and a Sandpiper; and that for the simplest reason imaginable-they did not know where to look for Snipe in wild weather, while we did.

It is, of course, unnecessary to tell any person acquainted with the first elements of Shooting, that the Snipe feeds, not on suction, but on small worms and other insects, which he collects by boring in moist earth with his long sensitive bill. His favorite feeding-grounds are, therefore, soft, sloppy tracts, where the soil is rich vegetable loam, or bog-earth, interspersed with springs, and sparsely covered with low, succulent grasses ;-earth, from the surface of which the waters have recently subsided, and on which a muddy, rust-colored scum has been deposited, on their 
subsidence or evaporation, abounds with food of the kind they most relish; and in such places they are often seen to feed. But in such, as the ground is either bare or but sparsely covered, they will rarely lie, so as to afford sport, until late in the season, when the young grass has acquired some height-when the sun has gained power, and repose and epicurean habits have rendered the Snipe tame and lazy.

If, however, we can find ground such as I have described, interspersed with tussocky bogs and tufts of long grass, affording shelter to the birds, into which they will run, and anong which they will skulk in ordinary weather, so soon as they discover the approach of intruders, the chance of sport will be very considerable.

In cold, dry winds, however, the birds will not even feed, much less lie to the dog, on such ground; and consequently we must in such weather look for them in very different places; places, indeed, in which no books of natural history, that I know, would lead us to seek them, and in some of which the authorities tell us they are never to be found.

But, to proceed in order; the Snipe when flushed never rises down wind, the resistance of the air appearing to be necessary to enable him to get under way. On his first rising, which he does for the most part about breast-high, he hangs on the air a little, before he gathers wing, and then darts away up wind, if possible, if not, across wind, tack and tack, with extreme rapidity, and with a zig-zag flight, which renders them puzzling objects to a beginner. I think, however, that to a person accustomed to their motions, they are as easy a bird to kill as any that flies. $\mathrm{Mr}$. Audubon states, in allusion to this supposed difficulty of killing Snipe, that he who can kill thirty in succession, without missing one, is a good hand at any kind of shooting. I suppose Mr. Audubon is speaking ironically; for if by can kill, he means habitually, or even frequently kills, he speaks of an impossibility. No man ever lived who could kill, in that sense, either thirty Snipe, or thirty of any other bird that flies, in succession. I have seen many crack shots in my life, both here and in England; but I never saw the man, and never expect to see him, 
who, shooting at every bird that rises in distance, can kill four out of five under the most favorable circumstances, day in and day out. He who bags three out of five, in covert and out of covert, trom March Snipe to December Quail, is a top-sawyer; and can hold his own anywhere, and against any one.

Some men may perhaps kill twenty shots in succession, picked out of fifty birds which ought to have been shot at; but my word for it, they will get easily beaten by the man who pretends to no such feat, but who pulls his trigger, whenever there is a chance of killing.

The real test of shooting, no less than of sportsmanship, is the finding and bagging the greatest number of birds within a given time, without the smallest reference to the number of shots fired.

The surest of all ways to ensure the never becoming a good shot, is to be afraid of missing. Shoot at everything that rises within distance, remembering always, as an old Yorkshire gamekeeper, by whose side I bagged my first Snipe some eight-andtwenty years ago, was wont to admonish me, that t' Snaipe was i' t' maist danger. If you miss, say with Jacob Faithful, "better luck next time," and endeavor to observe and remember how and why you missed him; whether you shot above, below, or to the right or left of him; this will give you steadiness and coolness at first; and, when you succeed in remembering, will have done much already toward preventing you from missing fair shots at least. For the rest, birds will dodge, at times, just when the trigger is drawn; boughs will be in the way; the sun will shine in the face of the best shots-moreover, the steadiest nerves will sometimes be shaken or unstrung, and the quickest finger will be a thumb on some days to the best sportsman.

I know a right good shot, and a good sportsman too, and a good friend of mine to boot, who does not pretend to kill quite three out of five, year in and year out ; but who is wont to say, which is very wrong of him, though I believe perfectly true, that he'll be $d-d$ if he can't beat any man, who can kill twenty shots in succession.

So much for thine encouragement, my young heginner. 
Good shots have killed twenty shots in succession; perhaps more, even in thick covert; but that is a very different thingr from saying can kill them. That, I am satisfied no man ever did, nor ever will do.

This, though applicable especially to Snipe, is true of all sorts of Game. After the observation, which has led me to this little digression, Mr Audubon remarks that he has found the I rst moment for pulling the trigger on a Snipe, to be that in which he utters his peculiar shrill squeak; and in this I perfectly agree with him; for the Snipe utters that cry as he rises, and before he gathers way; and I an convinced that the most killing way to shoot this bird, is to shoot at him during the instantaneous point of time in which he hangs on the wind-that is to say, to pull the trigger the very instant the butt of your gun touches your shoulder.

The old school method was to wait till the bird had done twisting, and was at some forty yards distance; but all that stuff, like taking a pinch of snuff after a bird rises and before raising the gun, was well enough for the days of long, singlebarrelled guns with flint locks. A gond shot of the present day would knnck over his dozen couple of right and left shots-not in succession, gentle reader-while one of those slow coaches was painfully picking up his half dozen. Cateris paribus, the quickest shot is the best shot.

Another maxim of the same age and the same school is, that the best dog over which to shoot Snipe is an old broken-down, slow Pointer-perhaps he is for a pot-hunter! Indeed, I believe, nine times out of ten, as many birds, perhaps more, could be bagged without a dog at all; or with a Newfoundland or Water Spaniel, kept entirely at heel, and only used to retrieve the dead or cripples; but where would be the sport of such slow gunning?

The best dogs for Snipe are the best dogs that can be got for money - the bravest, fastest, most industrious, and best brokenSetters, for my use, seeing that $J$ prefer them for all purposes but Pointers, if you will. 
If they be staunch, and have good noses, and back well, an 1 drop to shot, where they are, without stirring from the spot, ants without being shouted at, they cannot be too fust; and, if they will not do these things, it matters not whether they be fast or slow-they are worthless.

The most effective-sized shot for Snipe shooting is unquestionably No. 8. With coarser shot, the charge will be so much dispersed that so small a bird as the Snipe will constantly escape being hit, even when covered fairly; with smaller, birds will continually be wounded only, within point blank distance; and will frequently go away entirely unharmed. Farther than this, it is very rare to find a lever-topped belt or flask-which is by far the best implement for carrying shotthat will not suffer any shot smaller than No. 8 to escape, even when the spring is duwn.

Many English writers, I observe, recommend the use of two different sized kind of shot, one in either barrel; but this is, in my opinion, neither sportsmanlike nor effective. In all events, the barrels of a gun ought to be fired alternately; otherwise, as five single shots are fired for one double, one barrel will be worn out while the other is, comparatively speaking, new. My own experience has taught me that for all our Upland shooting, except that of the Pinnated Grouse, at all seasons of the year, No. 8 is the most effective shot. It will break the pinion of a Ruffed Grouse at fifty yards, and that is all that can be desired; .tnd when fired from a close-shooting gun, properly brought to bear, will riddle its target thoroughly at the same distance. All that is gained in weight and power by the use of larger shot, is lost in the condensation of a charge. This will be easily understood when the reader is informed that an ounce of No. 8 shot contains six hundred grains, or pellets, while No. 7 contains but three hundred and forty-one; so that at the same distance, with the same gun, the chances are nearly as two to one in favor of hitting a small mark with No. 8 over the larger shot; the greater the distance, the greater the advantage in this respect of the smaller pellets; inasmuch as all shot are propelled on 
diverging lines; and consequently, the longer the range the greater will be the interval between the grains.

When birds are very wild, however, I strongly recommend the use of Eley's wire cartridges, of the same No. 8 shot, which I consider an invention in gunnery second only to percussion. I will state here briefly, for the benefit of those who have not seen this missile, that the object of the contrivance is to propel the charge, like a single ball, for some fifteen or more yards from the gun's muzzle. After this distance the case bursts, and the shot diverges as in an ordinary charge. The gain, therefore, in distance, is precisely that to which the case is driven unbroken. This differs in the three different kinds of cartridges, blue, red, and green. The last of these must never be used, except in fowl-shooting on the bays, as the range is prodigious, and on Upland dangerous. The blue, which is the common kind, will increase the range of every gun, in closeness as in strength, from fifteen to twenty yards; and the red from twenty to forty. The more heavily you charge with nowder, the more closely will the cartridge carry; the converse of this proposition being true of loose shot.

It is useless, however, for any person to use Eley's cartridge, who is not cool enough to let a bird, which gets up under his feet, go away twenty yards before firing at him; and who cannot shoot well enough to kill at forty, with an exceedingly close carrying gun. I have shot Snipe, when very wild, and Quail in open ground, very late in the season, with blue cartridges in my first, and red in my second barrel, and that with great success. I would, however, prefer the use of loose shot and a blue cartridge.

With regard to dress, it may be well here to say a word or two; for Snipe shooting is a difficult and dirty business, as far as the walking is concerned, and requires an athletic frame, and a hardy constitution. For my own part, I have never found any contrivance succeed in keeping the feet dry; for a single fall, or heavy splash, things of common occurrence, will fill the tops of the longest and most secure water-proof hoots; 
Indian rubber is an abomination; as, if it excludes water, it also excludes air, prevents ventilation, and enclosing all the exudations and transpirations of the pores, is equally uncomfortable, unwholesome, and filthy. The moment boots are full of water, they are a dead weight, and of course a disadvantage ; I have, therefore, in all ordinary ground, long abandoned the attempt to keep dry; and invariably use laced ancle boots of heavy cowhide, for all sorts of sporting. These may be worn either with short gaiters and trousers; or, what I consider in every particular superior, and especially in the facility they give to movement in encumbered ground, or among brushwood and stumps, knee-breeches, and leathern leggins, buttoned on the outside. The breeches may be made of corduroy or fustian for spring and winter, of duck or drilling for summer shooting; and, if made long and loose from the hip to the knee, [ believe no walker who has once adopted them in this climate will ever return to heavy boots and trousers.

If, however, the Snipe-shooter is determined on endeavoring to keep himself dry, he had better provide himself with long boots from Canada, which he can procure, perfectly waterproof and of excellent quality, of any maker in Montreal or Quebec, for eight dollars a pair; whereas the same, not equally well-made, would cost him double the price, in New-York. I will here, farther state, that Mr. Cullen, No. 119 Broadway, New-York, is the only workman on this side the Atlantic, whom I know, that can turn out a real-working-shooting-boot or shoe.

If you adopt my plan, reader mine, you must make up your mind to get wet through in five minutes after going out, and to continue wet through, until your return home at night; but believe me, as in many other cases, ce n'est que le premier pas qui coute, the first shock is all that you have to dread; the water witrin the shoe immediately becomes warm, by contact with the foot, and you think no more about it, after five minutes; while in a long day's fag the absence of the heavy, dragging' 
water-logged jack-boots will make a difference in favor of your comforts, that words can hardly describe.

About a shooting-jacket, I have only to say that it caunot be too easy, or have too many pockets. For material, every man has his own fancy; I prefer strong corduroy for winter, and drilling or Russia duck for summer. Game-pockets filling the whole inside of both skirts will be found to carry a large bag with much less exertion to the sportsman, than the ordinary game-bag.

A low-crowned, broad-brimmed hat is as good for open shooting as any other head gear; but for covert work, a close skullcap, with a long peak, is the thing.

The best preparation for keeping boots, or leathern leggins, $s o f t$, is currier's dubbing, which can be procured of any tanner. The best water dressing is equal parts of tar, tallow, and Venice turpentine, melted together in an earthen pipkin, and brushed slowly and gradually into the leather, before a slow fire, with a painter's sash-tool. This should be repeated every time the boots are used; and it is well to observe that sun-heat is far superior to fire-heat for the drying of wet boots; and that it is scarcely possible to dry saturated leather too slowly.

These short memoranda, with regard to dress, will do once for all; they are equally applicable to all seasons and sports, and I am not aware that anything more of real advantage could be said in a volume on this subject.

Now fully equipped with all things necessary for our sport, we will take the field; and supposing the morning to be favorable, with a light breeze from the south-westward, the sky sunny, yet shadowed by floating clouds, the herbage underfoot $d r y$, but the soil moist and succulent, we may make sure of sport.

In the first place we will begin to beat, and persist in beating our ground down-wind, even if we have to make a large and tedious circuit in order to do so. The advantage of this, arising from the habit of the Snipe, before mentioned, of rising invariably up-wind, is that the wild birds will be compelled to cross us 
to the right or left, affording much closer and easier shots, than if we hunt them in the ordinary manner.

I am aware that there is an objection to this, in the fact that the dogs in some degree lose the favor of the wind; but dogs, properly broken to this sport, should quarter their ground regularly before you, working with their noses up-wind, and crossing and recrossing at every forty or fifty yards, and will find no difficulty in pointing such birds as will lie to them.

It is wonderful how easily dogs, which are always shot over by the same man-he being one who knows his business--will learn to cross and requarter their ground, turning to the slightest whistle, and following the least gesture of the hand. I have seen old dogs turn their heads to catch their master's eye, if they thought the whistle too long deferred; and I lately lost an old red Irish setter, which had been stone-deaf for his two last seasons, but which I found no more difficulty in turning than any other dog, so accurately did he know when to look for the signal.

When a dog has once learned that it is by his master's will, and not by his own, that he is to beat his ground, it is extraordinary how eagerly he will consult, and how readily he will soon come to perceive, his pleasure.

I have repeatedly tested the two modes of shooting Snipe, up and down wind ; and that with dogs of all kinds and conditions, and $I$ have no hesitation in declaring my conviction, that by working down-wind, especially in very wild and very windy weather, when birds lie the worst, one-third more shots may be got, and double the number of birds killed, than by giving your dogs, as it is called, the wind in their noses. In the latter mode, it is true, you will have your dogs continually drawing, and perhaps pointing, and will have the satisfaction of hearing the "scaipe, scaipe," of bird after bird, as he rises out of distance, and of seeing him zig-zagging it away up-wind, at a rate which sets even your blue cartridge at defiance.

Beating down-wind, on the contrary, the birds, headed by yourself and your dog, are likely enough to get confused and 
bothered, and to lie hard; and even if your setter or pointer do run in upon two or three, in a day's shooting, the odds are, as Snipe-shooting is always more or less snap shooting, that you will get a long cross shot at these, and perhaps bag them; and, at all events, for every bird you lose thus, you will lose four which will whistle away unshot at, dead in the wind's eye, if you beat up-wind.

I had once an actual trial of this kind accidentally, and on my part unconsciously, with a rather famous English dog-breaker and market shooter, on the Big Piece, a superb and very extensive tract of Snipe-meadow, just above the Little Falls, on the Passaic, the result of which $I$ will mention as tending to exemplify the fact I have been insisting on.

I did not at the time know this fellow, though subsequently I have known him to my cost ; though I afterwards heard that he was acquainted with my person, and had made some small bet, or other, on beating my bag ; which, but for his want of knowledge on this point, he would have done, for I believe he is a better shot, and he had decidedly better dogs than I on that day; the best of which became mine in consequence.

It was a very wild morning, indeed, early in April, the wind blowing almost a gale from the westward; and immediately orr entering the meadow, I perceived a man in a black velveteen jacket, with three very fine dogs, one the red setter I have named before, beating up-wind at some three hundred yards distant. I set to work after my own way, and so we persevered all day long, he beating up, and I down wind, often within a hundred yards' distance. There were a great many birds on the ground, and I had very fair shooting, getting at least three shots to his two, and those much fairer shots; in proof of which I may observe, that I killed three or four double shots during the day, while he did not fire one. At about four in the after noon we parted company, not having interchanged speech, and I thought no more about him until I returned to mine inn, when I learned that $\mathrm{D}$ _ had called to inquire how many birds I had killed, and expressed his wonder that a person who, as he was 
flattering enough to say, did know something about sl:ooting, should be such a flat as to shoot Snipe down-wind. In the evening he came into the bar-room, and there found, first of all, that I had beaten him by some half-dozen birds, which he said he expected ; and, secondly, that it was for a reason, and not for the want of one, that I shot Snipe down-wind. He admitted at once, that he saw throughout the day that I was getting more and better shots than he, whereat he marvelled, seeing he knew himself better dogged than I; but that he still marvelled why I should shoot down-wind. He was, however, open to conviction, and was, perhaps, not sorry at having a reason to give for being beaten.

Double shots at Snipe are by no means uncommon-commoner, I think, than at any other species of game-for although, as a general rule, the snipe is a solitary bird, both in his habits of flight and feeding, and acts independently of his neighbors, you will usually find numbers of them feeding nearly together, and rising nearly at the same time, because alarmed by the same sound. Under these circumstances, however, they do not usually fly off together, like a bevy of quail, or a plump of wild fowl, but scatter, each at his own will. Now as the wildest birds always spring first, it often happens that your discharge, at a long shot, flushes another much nearer by ; I therefore strongly urge it on beginners to be.a little patient, and not to blaze away both barrels in succession at the same bird, or even at two birds, nearly out of distance, since by doing so they will very often lose a good chance of bagging a bird close at hand.

It is, moreover, a very absurd and unsportsmanlike practice to fire at Snipe out of shot, yet it is a very common one. The Snipe is a very small bird, and offers, particularly when flying directly from the shooter, an inconceivably small target. It is not possible that one can be killed, with anything like certainty, at above fifty yards,--I name an extreme limit. Now, in ordinary weather, the odds are about three to one, that a bird flushed, and not uselessly shot at, at this distance, will alight again within three or four hundred yards, or upward, and perhaps afford 
a good chance, and lie to a point. But blaze at him, and perhaps sting him with a stray shot, and he shall fly you a mile at a stretch ; besides that, your shot has disturbed the meadow, and perhaps flushed half-a-dozen others. Let it not be supposed, however, that I would inculcate slow and poking shooting; on the contrary I abhor it.

The most unsportsmanlike thing that a man can do, in this line, is not to fire at a bird, when there is a reasonable chance of killing it ; the next, is to fire at a bird when there is not a reasonable chance of killing it.

Snipe-shooting being practised ninety-nine times out of a hundred in perfectly open ground, the birds can be marked by an experienced hand at the work, to a great distance, and to a great nicety. But there is a good deal of knack in it; and I hardly ever saw a countryman, who did not shoot, who did mark even decently. An ordinary observer, when he loses sight of a bird flying low, is apt to suppose he has stopped at the puint where he last saw him, a conclusion than which nothing can be more erroneous.

Every bird has his own fashion of alighting from the wing, and that of the Snipe and Woodcock is very peculiar; they both jerk themselves a little way up into the air, make a short turn, and pitch down backward. Once nuticed, this motion cannot be mistaken; and once made, you may be sure that the bird has dropped. All that remains to be done is to mark the place, so as to find it again, which in an expanse of open pasture or meadow-land, waving with even grass, or covered with tufts of rushes, each one precisely like its neighbor, is far from an easy matter. The better way is to raise the eye slowly from the spot toward the horizon-in case the ground is quite devoid of any near landmark of stump, bush, pool, or the like-where you w.ll be nearly sure to find some tree, building, hill-top, or other eminent object, which you may bring into one line with your bird. after which you will have no difficulty in finding him.

In marking dead birds within a near range, you should ever endeavor to fix the very leaf, or branch, or bunch of grass, on 
which it has fallen; and I have found it a good plan, on stepping up after loading to look for your game, to drop your hat, or handkerchief, on that which you conceive to be the cxact spot; otherwise, while looking round among the grass, it is not uncommon to lose the direction altogether. In covert shooting, in marking a bird, whether shot at or not, which flies behind a brake, impervious to the sight, cast your eye quickly forward to the next opening, a little above the line of the bird's flight, if he is rising, or below, if dropping on the wing, to make sure that he does not pass it. If a killed bird is hidden from you by the smoke of your own fire, and you perceive by the stream of feathers that he is dead, allow a little for the speed and direction of his flight, which, if he was going fast when struck, will often throw him many feet forward of the spot where the shot smote him. The shot itself, if close by and hard hit, will at times pitch him a yard or two out of his course.

A Snipe will sometimes, but not generally, carry away a good many shot; but when he does so, if marked down, he almost invariably rises again. Neither he nor his congener, the Woodcock, is in the habit--so common with the Quail, and sometimes with the Ruffed Grouse--of flying away with his death-wound and dying before he fal's. A Quail or Grouse, shot through the heart, or through the brain, will constantly tower, as it is termed, directly up into the mid-air, with a perpendicular flight, and quick beating of the wings, which are kept up till he vital spark leaves the bird literally in the air, when it turns over on its back, and falls like a stone. In windy weather many Quail are lost thus, drifting out of reach; but I never saw this occur with a Woorlcock, and never but once with a Snipe, which then only flirted up a few feet, with an expiring effort.

When, therefore, a Snipe goes away hard hit, mark him carefully, and approach the spot stealthily,--it is all a toss-up whether he lies like a stone, or whirls up at sixty paces, when he hears you coming. But however hard he may lie, never relax your watchfulness, or put your gun under your arm, or over your shoulder, till he is bagged. I have seen a crippled bird 
marked to a square yard, get away, owing to the conviction of the pursuers that lie was dead, after the ground had been beaten to and fro by a brace of capital dogs, and trampled all over by as many men ; and I should like to know what can be more provoking than such a consummation.

For Snipe shooting, the most effective party that I can conceive, will consist of two men, provided that they are sufficiently well acquainted each with the other's style of shooting and hunting dogs, to work well together,- - and two dogs, both belonging to and hunted by one man. In this case the sportsman can hunt their dogs alternate days, he whose turn it is not to hunt, carefully abstaining from uttering a word, or making a gesture to the dogs.

This, of course, can be only done by two old sportsmen, who know each the other's style of sporting, and will consent to give and take mutually something.

The advantage gained is this, that a brace of dogs, used to one another, knowing one another's ways, and accustomed to work and live together, will do twice as much, and five times as good work, as a pair of strangers, jealous, and very likely broken in to different styles of action.

No two men hunt their dogs precisely alike,-and, consequently, no two strange dogs, hunted by two different strange men, can or will work harmoniously together. If each man insists on hunting his own dog each day, the men will have better sport by hunting singly. But, in my opinion, one man wants a brace of dogs in the field,-and yet a brace of dogs are enough for two men. When the number exceeds two guns, for Snipe shooting, by far the better way is to divide into two parties, beating, if you please, in sight each of the other, and so driving the birds backward and forward,-but not sufficiently near to allow the dogs to mix, or become jealous.

The difficulty of getting dogs accustomed to different styles of sporting, to work well together, will be evident at once, if we consider that one sportsman trains his dog to drop to shot, where he is when the shot is fired; another, to come in before 
charging; that one insists on his dog pointing his dead birds before fetching them; another suffers his to go on and fetch as soon as he has loaded; and yet a third takes no heed at all, but suffers his brute to rush in as soon as the gun is discharged.

The last is, of course, a barbarism, to which no one worthy of being called a sportsman will resort; the others are still held to be mooted points; and there are sportsmen who hold to both I do not myself admit any doubt on the subject; nor do I esteem any dog broken, which does not drop to charge, at the report, without stirring from the place,-which does not lie at charge, until ordered to "hold up," and which does not point his dead game, until desired to "fetch." Still, so long as diversity of opinion exists on these points, and dogs are broken according to the good or bad judgment of owners and breakers, different animals cannot be expected to hunt harmoniously together; and so unfortunate is the propensity both of men and beasts to learn evil more easily than good knowledge, that two or three days' companionship with a rash, headstrong, rushing brute, will, it is likely, play the very deuce with your carefully broken dogs, and cause them to contract tricks, which it will cost you much pains and trouble to eradicate.

It is so very common an occurrence, while in pursuit of spring Snipe, to find different kinds of Wild Duck, particularly the two varieties of Teal, the Wood Duck, the Mallard, and the Pintail, that it is well worth the while to carry a few red cartridges of No. 1 or No. 2 shot,-Col. Hawker observing of these missiles, " that for a wild open country, or shooting by day at wild fowl, he cannot say too much in their favor in their present improved state."

It is scarcely necessary to state here, that when two persons are shooting in company, neither must on any account think of firing at a bird which, however fairly it may rise to himself, flies across his companion. Each sportsman should take the bird which flies outwardly from the common centre ; by doing which he will not only avoid the incivility of shooting across his friend's face, but will, in the long run, bring many more birds 
to bag ; for, without some such understanding, both charges will constantly be delivered into one bird, while others are going away unshot at.

It is a most uncourteous and clownish fashion, that of shooting across a companion's face, if committed fiom ignorance only, or carelessness,-if done from jealousy, and a grasping desire of making a larger bag, it is unpardonable and ungentlemanlike. A fellow who would do it, should be sent at once, nem. con., to Coventry.

The genuine sportsmen will always give, rather than take; and, even in the case of single birds flying forward in a direct line before two guns, the shot should always be yielded, especially by the person who hunts the dogs, and who may be in some sort regarded as at liome, and therefore bound to do the honors to his comrade.

Where two persons shoot much together, it is well to take such shots alternately; and there is another advantage gained by this, as there is by the practice of all punctilios in sporting, that it tends to promote equanimity and coolness, without which nothing great can be effected in this line.

So long as the weather holds fair, and the birds lie well to the dog, there remains, I believe, no more to be said on the subject. But it must be observed, that in wild, windy weather, early in the season, if we know that there are birds on the range, that they have been killed on the meadows in numbers, and for successive days, and that there have been no heavy frosts to banish them from the district, they will be found, as I have before hinted, in haunts altogether different from their usual feeding ground. So soon, therefore, as it is evident that they are not to be found at all, or in anything like adequate numbers, on the meadows, it is advisable to turn your attention instantly to the skirts of the nearest woodlands, under sheltered leesides of young plantations, among willow, alder, and briar brakes, and, in short, wherever there is good soft springy feeding ground, perfectly sheltered, and protected from the wind by trees or shrubbery.

VOL. 1 . 
I first observed this habit of the American Snipe, which is utterly at variance with the habit of its European congener, at the English Neighborhood, on the Hackensack River, where, by mere accident, I stumbled on a number of birds in the cowpaths, among thick brushwood, far above the salt meadows, toward the Upland. I next found them in similar ground on a very wild day, at the end of March, or the beginning of April, on the Long Meadow at Pine Brook. On that occasion the birds were all busily employed in drumming, - - a habit of the Snipe, as it is generally stated by naturalists, during the breeding season. I have myself, however, never witnessed it, except immediately on their arrival in this district, long before they had even begun to pair. The habit is, however, clearly connected with their nuptial and vernal propensities, and probably continues from the commencement of their sexual intercourse, to the end of their incubation. It is performed, I believe, solely by the male bird, which rises in the air till he is almost out of sight, where he disports him for hours in mid ether, sailing round and round in small circles, and at times letting himself fall, fifty feet or more, plumb down, before he again sails on his wing. It is during these perpendicular descents, that this strange, powerful, and musical hum is uttered,-it is comparable to no other sound that I can name, and must be heard to be conceived. It is very pleasing and sonorous, and may be distinguished at a great distance. Once heard, it can be mistaken for no other noise, made by either bird or beast,- - nor will the sportsman be apt to forget it, as it is to him strangely ill-omened ; for, while it is going on, birds will rarely or never suffer themselves to be approached within gunshot,--rising, as soon as flushed, spirally into the air, each seeming to call up another by the sound, and sporting together aloft, "whirling round each other," to borrow the eloquent language of Mr. Audubon, "with extreme velocity, and dancing as it were to their own music ; for at this juncture, and during the space of five or six minutes, you hear rolling notes mingling together, each more or less distinct, perhaps according to the state of the atmosphere." I was surprised to find that 
Mr. Audubon here states his doubts, whether this sound is produced by the feathers of the wing,-or rather almost asserts his conviction that it is ventriloqous. I have lain on the turf for hours, watching them when in this mood, and when all farther attempt at pursuit of them would have been useless, and have observed their motions with a good glass. I am myself satisfied that the sound is produced by the fact, that the bird, by some muscular action or other, turns the quill-feathers edgewise, as he drops plumb through the air; and that, while in this position, during his accelerated descent, the vibration of the feathers, and the passage of the air between them, gives utterance to this wild humming sound.

Such likewise is the account given by European naturalists of the same sound which is produced by the Snipe there at the same vernal period; they mention, moreover, a peculiar cry of the male bird at this season, different from his shrill squeak, on being flushed, which is precisely identical in the American and European species-this they describe as resembling the word "Pect," thrice repeated in a shrill whistle. This I never have noticed in the American birds; but, on two different occasions, when the birds were at the very wildest, drumming away for hours at a stretch, and not giving even a chance of a shot, I have observed another cry, which I cannot find recorded either by Wilson or Audubon, any more than the practice, by which it is accompanied, of alighting on fences, stumps, and even on tall tree-tops.

This cry is a sharp, reiterated chatter, consisting of a quick, jarring repetition of the syllables, kek-kek-kek-kek-kek, many times in succession, with a rising and falling inflection, like that of a hen which has just laid an egg. This singular sound is uttered as the bird is descending from its gyrations and musical performances; and, after having descended, while it is skimming low over the surface of the bog meadows, previous to alighting. While in this humor, I have never seen them alight directly into the grass, but have invariably observed them to settle first on the stump of a dead tree, or on a rail fence, and 
thereafter drop into the rushes. On both of these occasions, the birds lighted many times on the very topmost branches of the willows, and other trees, which lined the fences; and on one ocrasion, I saw a Snipe take flight from a branch, rise upward, and resume bis drumming, without first returning to the level ground.

On the day when I first witnessed these performances, which astonished me, I confess, little less than it would have done had they begun to sing "God save the King," or " Hail Columbia," which would perhaps have been more appropriate-I observed that when, at length, they ceased diumming, which they did as the day grew hotter, they all flew off in one direction, toward some meadows overrun with brakes, cat-briars, brambles and thorn bushes; and herein I had good sport with them for several hours, after having despaired, in the morning, of getting a shot at all.

Since that time, I have repeatedly found them in similar ground at Chatham, yet higher up on the course of the Passaic. where there is a great deal of covert of that particular naturelow stunted bushes, and briar patches, growing in boggy, springy ground. So notoriously is it the case that Snipe, on their first coming, there frequent such localities, whenever the weather is not more than commonly warm and genial, that it is the habit of many old sportsmen to beat for them regularly in such places, without trying the meadows at all, on their first arrival. I have killed hundreds of couples in such places; and have put up scores, at a small enumeration, of Woodcock, then sitting on their eggs, from the self-same coverts at the same time. Indeed, the same brakes, a little later in the season, afford the very best cock-shooting. Once, and once only, at the same place, Chatham, during a snow-squall, I shot several couple of Snipe in a very thick piece of swampy woodland, among tall timber-trees with heavy undercovert-precisely what one would call armirable summer Cock-ground-the Snipe flew in and out of the brakes, and thridded the branches, as rapidly as Quail or Cock would have done, in similar thickets. What has happened 
once, especially in the ways of animals, is like to occur again ; and 1 should not hesitate, when there was no tract of low springy underwood near at hand to Snipe meadows, to beat high wet woodlands for this bird, during the permanence of cold storms and violent winds, sufficient to drive them from the open fields. At all events, let the sportsman remember that in the Middle and Eastern States, bushy ground, briar-patches, alder and willow brakes, and the like, are as regular haunts of Snipe in spring, as bog tussocks or marshy meadows; and that there is no more propriety in his omitting to try such ground for them, than there would be in neglecting to leat thickets and dingles for Quail, because they ordinarily feed on stubbles.

While I am mentioning the peculiar habits of the American Snipe, such more particularly as it is not generally known to possess, I may observe that although not web-footed, or even semi-palmated, this little bird swims rapidly and boldly. I was previously aware that, on falling wing-tipped into the water, it was able to support itself, and even to struggle away from a dog; but I had no idea that it would take the water of its own accord, till I was a witness to the fact under rather singular circumstances. I was standing still, loading my gun, both barrels of which I had just discharged, on the brink of a broad spring-fed ditch which runs along the lower side of the Long Meadow, when a bird, flushed by a friend at some distance, flew over my head and dropped within ten feet of me, on a spot of bare black soil, between two or three large grassy tussocks, and the ditch. I had never, at that time, observed the natural motions of the Snipe, when unalarmed; and I stood watching him, for some time, as he walked gracefully to and fro, and stooped down once or twice and bored in the mud, vringing up each time a small red angle-worm in his bill, utterly unconscious of my presence. After a minute or two, he deliberately entered the ditch, and oared himself across it, as easily and far more gracefully than any water-fowl could have done. I have since regretted, that I did not show myself at this moment, in order that I might have ascertained whether it pos- 
sessed the power of taking wing from the surface of water, which I" am greatly inclined to doubt. I was well aware previously of the fact, that many of the Shore-birds and Sandpipers swim on emergency, but I little suspected the Snipe of possessing the like power.

I know not that the being acquainted with this habit of the Snipe can materially aid the sportsman; but, in case of dogs drawing on the trail of birds, which had run and fed, up to a brook-side, or on the foot of a wing-tipped bird, I should now certainly try forward, across the water, which I should not previously have done.

The peculiarities of cry, flight, and perching, which I have related above, are well known to many of our sportsmen here; and I can readily produce half-a-dozen witnesses to the various facts I have stated, within a dozen miles of the room in which I am now writing; as well as to the bird's occasional habit of resorting to the interior of woods, which Mr. Audubon positively asserts that he never does.

By the way, since penning the above, it just strikes me that in the Spring of 1840, when the snow was not entirely off the Uplands, in shooting with a friend from Quebec, we moved three Snipe from a little piece of white-birch woodland, one of which was shot by my companion, and retrieved by my setter in the bushes, and a second of which I killed over a point in the next field, not very far from Lorette.

I am inclined to believe all these habits to be purely local, as concerns the American bird. Not local, owing to any peculiar circumstance of the place, but of the seasons in which the bird visits or frequents the places. In other words, I suppose them all to be connected with the amorous and sexual intercourse of the birds, and to commence and terminate with the breeding season.

In the summer, when I have shot a few young birds during Cock-shooting, and in the autumn when I have killed five times as many as I have in spring, I never heard any cry from the Snipe except the regular "scaipe;" nor have I ever seen 
it inauifest the slightest inclination to alight on fence, rail, log or tree. I therefore, suppose these habits to be, like drumming, peculiar to the season, and analogous to the circling and strutting of Doves, the fan-tailing of Peacocks, and the like. I should be curious to learn, however, from my Southern friends, who kill them during the winter in far greater numbers on their Georgia and Carolina rice fields than we can pretend to do on our barren bog meadows, whether they are ever known there either to take to woodland coverts, or to tree.

The English Snipe, I am certain, never does either, both from my own experience, and from the observation of many older and better sportsmen than myself. I have shot the English bird constantly, and for several successive springs, in the fens of Cambridge and Norfolk; and I have heard him drum there more frequently than I have here, but I never heard him chatter, or saw him take the tree; and I am certain that he never does so.

While speaking on this subject I must observe, again respectfully differing from Mr. Audubon, who asserts that "there is as great a difference between the notes of the English and American species of Snipe, as there is between the American Crow and the Carrion Crow of Europe," that in my opinion the cry of the two Snipes is perfectly identical; and in this view I am corroborated by the judgment of several English sportsmen, with whom I have habitually shot for many seasons here, and who, like myself, had killed nundreds of couples of Snipe, before visiting America. The number of feathers in the tail of the European and American species differs; and I am nearly certain that the English bird is somewhat larger and heavier-Wilson, who first distinguished the two species, notices the difference in size-but otherwise in appearance, and in all their ordinary habits, they are identical. I lay, however, great stress on the difference of note, in the breeding seasoll, and in the other peculiarities alluded to, as setting the question of variety on a much broader and more distinct base, 
than the distinction between sixteen and fourteen tail-feathers, and an inch more or less in length.

Until I saw the American Snipe perch in tall trees, and heard them cackle like laying Pullets, I regarded the difference between the species as merely nominal. Every day since that time I have more clearly discerned its reality; and have in consequence learned to look for them, and find them too, where I should as soon have thought of hunting for an Ostrich as for a Snipe, in England.

With regard to the habits of the bird in summer, I know little; but that little is enough to enable me to say that they are in no wise different from his autumnal customs. The Snipe returns to Lower Canada, from the northward, with the young birds full fledged in July, and is at that time, and until driven away by the frost, shot in immense numbers on the marshes at Chateau Richer, at Goose Island, and hundreds of other places down the St. Lawrence. Along both sliores of the Great Northern Lakes they abound, at the same time, or a little later; and accordingly as the season sets in early or late, so do they regulate their arrival with, and departure from, us. The earliest period at which I have ever killed migratory Snipe, birds I mean not bred here, is the 12th of September; when, in 1842, I bagged fourteen couple and a-half in a deep bog-meadow at Chatham. The latest day, on which I have shot them is the 9th of November, at Pine Brook. I have been assured, however, by an excellent sportsman, on whose word I can fully rely, that he has killed them on a spring brook, in which the water never freezes in the hardest weather, daily, until the 19th of December. This was in Orange county, moreover, where the frost sets in at least a fortnight earlier than it does below the Highlands of the Hudson. The same gentleman, some years since, killed thirty-five Woodcock on the 13th day of December; a circumstance, so far as my knowledge goes, anparalleled in this region. There is, however, no possible doubt of the fact; as, being himself aware of its strangeness, he took unusual pains to verify it by sufficient evidence. There 
had been, if I do not err, a very early fall of snow, succeeded by hard frosts early in November, and after that, uncommonly mild and open weather.

In autumn Snipe-shooting there is nothing to be observed, except that the birds are more composed and less restless than in the spring; that, unless persecuted and driven from the ground by incessant shooting, they linger on the same meadows, until the coldness of the weather compels them to travel southward; that they lie much better to the dog, allowing themselves to be pointed steadily, and rarely flushing out of fair distance; and, to conclude, that they are much fatter, much larger, much easier to kill, and much better eating than in the spring season. I have never seen them in bushy ground, or even among briars, in the autumn, though I cannot state that they never take to such places.

Mr. Audubon states the weight of the American Snipe at 3 oz. The average weight of the English species is $4 \mathrm{oz}$. I never, but once, weighed any American birds. I was then struck by their apparently unusual size; when I weighed twenty-five together at the tavern at Pine Brook, and they averaged within a small fraction of $5 \mathrm{oz}$. each.

The Snipe is delicious eating, inferior to no bird that flies, save the Upland Plover, and the Canvass-Back Duck. Like all birds that feed on, or near the water, he must be eaten fresh. A true gastronomer abhors Woodcock, Snipe or wild fowl, in the slightest degree high. Gallinaceous game are the better for keeping, wild fowl and waders are ruined by it. If possible they should be eaten within twenty-four hours after being killed.

They should be carefully picked by hand, on no account drawn - that is a practice worthy of an Esquimaux, as is that of splitch-cocking and broiling them-the neck should be bent downward, and the bill run transversely through the body, immediately below the pinions; one leg thrust through the sinew of the other thigh-they should be roasted, at the outside, ten minutes before a very quick, brisk fire; with no condiment, or 
butter - a thin slice of crisp buttered toast should be laid under them while cooking, to catch the gravy and trail, if it chance to fall out; and this is to be served up under them, when dished for the table. Any made gravy or sauce is an abomination; and the practice of blanketing the birds while roasting in slips of fat bacon should be held the death-warrant of any cook, in a well regulated family. A little salt, and bread quantum suff. may be eaten with him; and a glass-or if you please bottle -of chambertin drank with him-but, as you live, eschew sauces, vegetables, or-small beer!

More people, I believe, know better how to kill a Snipe secundum artem, than how to cook him decently, or eat him gracefully, when slain. It becomes the sportsman to shine in both capacities; and, though myself I partake a little too much of the true Spaniel's quality to care much about eating game, I should at least have him eaten, if eaten he must be, as a dish for gods, not as a carcase for hounds. 



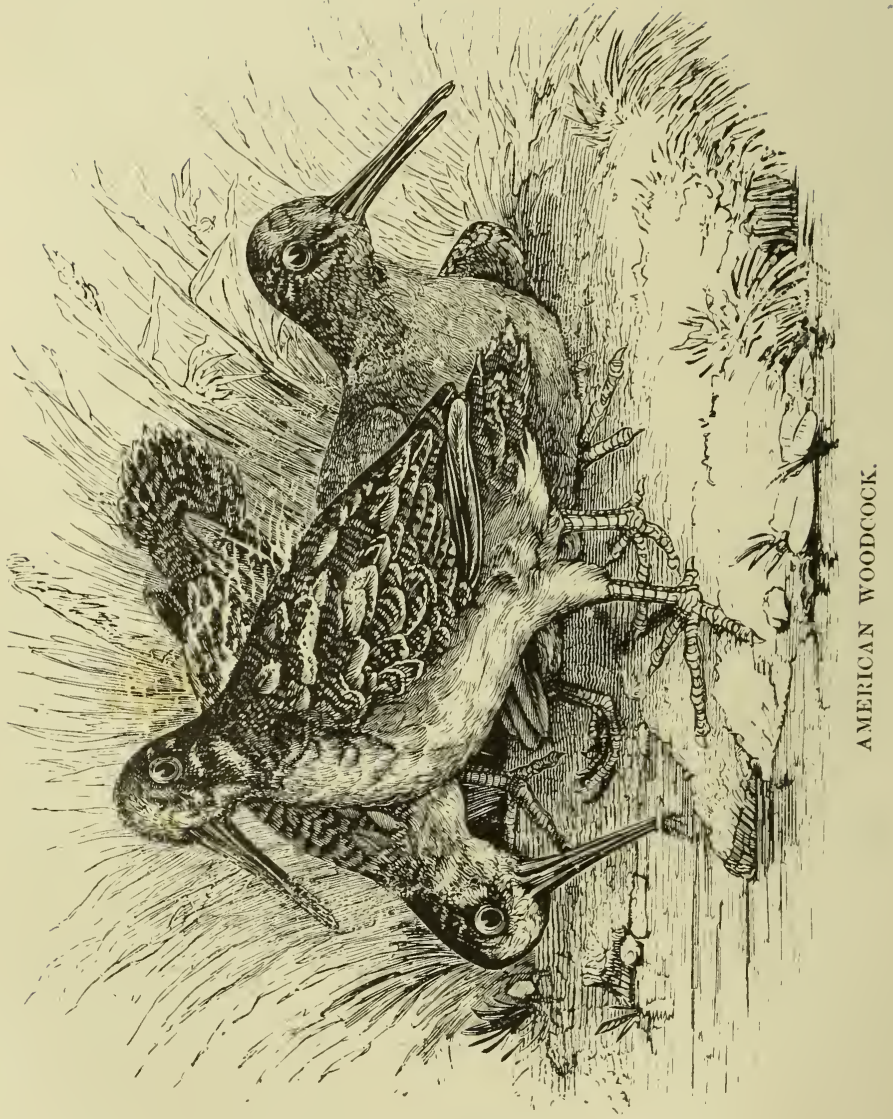




\section{SUMMER WOODCOCK SHOOTING.}

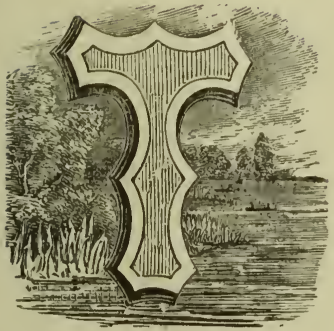

$\mathrm{HE}$ wisdom of our game laws has decided that Woodcock shall be killed and taken, by all and sundry, in the State of New-York, on and after the first, in the State of New Jersey on and after the fifth day of July; although in the latter State the practice of the sovereign people has determined that the fourth is the day intended by the enactment, and on the fourth, accordingly, the slaughter commences. In Pennsylvania, and Connecticut, practice at least, if not lawand until recently, if there be now, there was no statute on the subject-has prescribed the same, or nearly the same period, for the commencement of Cock-shooting; and even in those counties of New-York to which the enactment of these game laws, such as they are, does not extend, tacit agreement has prescribed the same regulation, at least among sportsmen.

So far, indeed, has this practice been carried, that by means of a convention of this sort, the shooting of Woodcock is tabooed, until the fourth of July, even in the islands of the Great Lakes and the Detroit River. The example was set by the officers, I believe, of the American and British garrisons at Detroit and Amherstberg, acting in concert, and the practice has almost become common law.

The fact is, therefore, that everywhere through the United States and the British Provinces, whether there is or is not any distinct law on the subject, the commencement of J lly is as 
regularly hailed the legitimate time for Woodcuck shooting, as the first of September in England for Partridge.

In New Jersey, which is in almost every respect a century behind all the neighboring States, there is a special proviso that on his own ground every man may kill all sorts of game whenever he pleases, without the slightest reference to common sense or humanity, and may give permission, to any one he pleases, to do likewise. A proviso, which not only abrogates the whole law, in point of fact, but in truth gives the poacher a clear advantage over the honorable sportsman.

There is, however, I imagine, no prospect of any alteration of this law, which is in perfect keeping with the pig-headed stupidity manifested throughout the legislation of that State. And why, in fact; should not a man be allowed to kill Woodcock whenever he likes on his own ground, in a State wherein a company is licensed to kill men and women, whenever they like, on their own rail-road; and charge them whatever they like for killing them into the bargain?

On the first of July, then, Woodcock shooting legitimately commences; although before that day hundreds, nay thousands, are killed along the sea-board, and notoriously offered for sale by almost all the restaurateurs and hotel-keepers in New-York, the utmost efforts of the Sportsman's Club to the contrary notwithstanding.

At this period, about four-fifths of the birds-the young birds, of course, I mean-are half grown or thereabout, some only being a few weeks old, and others, in late and adverse seasons, scarcely hatched.

The Woodcock commences laying as early as the beginning of February, and sometimes lays so late as to the end of June, or the beginning of July. The eggs are four, and sometimes five in number, - of no more than this does any naturalist inform us. Whether the old birds regularly breed a second, and third time, what becomes of the young birds of the first hatching in the meantime, and whether they are protected by the male hird, is all left dark. 
Now, although the length of time occupied by incubation, is not laid down in the books, it cannot exceed eighteen or twenty days,- - the young birds run the moment they clip the shell; and it is stated by Mr. Audubon, I doubt not, correctly, that at six weeks' old, they are strong and quick on the wing. According to this, there should be many birds well on the wing early in April ; and from all we know of the growth of these birds, no difference being manifest after the August moult between the old and young, these should be fully equal to the parents in size on the first of July.

I have myself no doubt, that the Woodcock regularly breeds twice, and sometimes thrice a season, although it is certain that young birds of two different sizes, and consequently different hatchings, are never found in July with the same parents.

It occurs to me, but I cannot be sure of the fact, as I only speak from vague recollection, that in the few cases where it is possible to be assured, that all the birds killed are of one brood, --as, for instance, in small hill-swales, and the like, containing one resting-place-I have never seen above one old bird with the brood. In adverse seasons-the worst of which are those which, after a favorable and early spring, become cold and wet in May and June,-when the first brood is destroyed by floods. the old birds do unquestionably breed a second time, and hatch a very late brood, so late as to the middle of July. And of this, I think, the following anecdote will be held sufficient proof and confirmation.

This anecdote was published by me some two or three years since, in the columns of a leading monthly magazine, in connection with a number of remarks concerning the habits of the Woodcock, on some of which I have since been led to alter my opinion. I was, at that time, inclined to believe that the parent birds retained several broods of young, of different sizes, about them ; but I am satisfied that this view of the case was erroneous, and was induced by the accident of two or more broods having come in contact, as is perpetually the case on well stocked ground, under the care of only one parent bird each. 
The only way to verify the facts satisfactorily, would be to mark down, in the daily return of game killed, the number of old birds in proportion to young, and to ascertain the sex of the former by dissection. The female bird, it is true, is somewhat the larger; but it is not safe to reckon on the eye, or even on the scales, for the determination of the sex. By the way, I conceive that there must be some error in the printing of Mr. Audubon's statement concerning this relative disproportion. He states the weight of the male bird at $6 \frac{1}{\ddagger} \mathrm{oz}$., which appears to me, beyond all question, inadequately low,--and that of the female, at $8 \frac{1}{2} \mathrm{oz}$.; while in length the female exceeds the male only by $\frac{7}{12}$ of an inch. This difference is inconceivable, not to say impossible. The understatement of the male Woodcock's weight struck me at first sight ; and I endeavored to account for it to myself, by supposing that Summer Cock had been assumed as the base of calculation. I presume now, that $6 \frac{1}{4} \mathrm{oz}$. is a typographical error for $8 \div$; which I should have stated, if asked suddenly, as about the average weight of a full-grown Woodcock. The bird from which the accompanying wood-cut was taken, shot by myself on the 23d of October, 1843, weighed $9 \frac{1}{4}$ oz., measured 13 inches from bill to claw, and 18 from wing to wing extended; but this was an uncommonly large bird. I have, however, heard of their being killed up to $11 \mathrm{oz}$. Once for all, it appears to me that Mr. Audubon understates the weight of his game birds generally. The coming season I will carry a small scale in my jacket pocket, and would earnestly urge it on every sportsman to do the same. They can be obtained at any tackle shop, and will weigh up to 10 or $12 \mathrm{lbs}$, being as portable as a common pencil-case.

A few years since-I think it was in 1841-there was a deep fall of snow, covering the greater part of the State of New York, near eighteen inches deep, so late as the 12th or 15th of May. It thawed, of course, immediately, and produced a complete inundation, the early spring having been rather uncommonly dry. From this I augured ill for the prospects of the shooting season. But fine weather followed, and by most persons the Spring snowstorm and fieshet were forgotten 
On the first of July I went with a friend, a good shot and eager sportsman, to a favorite shooting ground, in Orange county, $\mathrm{N}$. Y., on a part of which-for it had a very large range, and contained many varieties of lying-we had bagged on the previous year a hundred and twenty-five birds in a single day's shooting.

We shot the first day on the low meadows, and killed hardly any birds; not, to the best of my recollection, above ten or a dozen, in a severe day's walking. They were well grown birds, but not a single old one in the number. My companion, greatly annoyed, insisted that the ground had been hunted before that season, and all the birds killed off, except the handful that we had found. From this conclusion I dissented, arguing that if sucl had been the case, we should have found old birds, the young being the easier both to find and to kill, especially for cockney sportsmen, who alone may be presumed to hunt before, that season. My friend grew almost angry, and asked me, "Where, then, are the birds?" I answered, "Wait till to-morrow evening, when we shall have beat our other ground, and I will tell you."

The next day we did beat the other ground; wet swales, and sloping woods of small extent in valleys watered by little streamlets from the hills. The result was the same, a wretched day's sport, and no old birds, or at least hardly any.

As usual, each held his own position; my friend again asked, "How do you account for this?" I replied, "All the young broods have been destroyed by the freshet, except the very few which got off before the May flood. This accounts for the fewness of the birds, and for the uncommon size of those few. The old birds are now hatching their second broods on the ridges and hill sides. I will show you that I am right, to-morrow." And to-morrow I did show him that the ridges and sapling covertssprouts, as the country people call them-were full of old birds, hovering, and no young ones.

Still my companion was incredulous as to the second broods, until in the afternoon, as I was passing through a little clump of 
alders, not above two or three yards square, I flushed a bird which flew out to him. He fired. I called out to enquire whether he had killed, and as he answered "yes," I heard the bird flapping its wings on the ground, in the death-struggle, as I imagined. Knowing that he could recover the bird, in the open ground, I beat out the thicket thoroughly, and left it, satisfied that it contained no other bird, though I had some difficulty in getting one of my Setters away from what I supposed to be a field mouse. On joining my friend, he told me that the bird had flapped up, when he was in the act of laying his hand upon it, and had staggered away, seeming every moment on the point of falling, so that he did not care to fire at it again, until it got out of shot; but that he had marked it down to a yard, in a thick brush fence, three or four hundred yards away. On going to the place, the dogs took the scent readily; but, while they were trailing it, the bird rose, a hundred yards off, flapping and staggering about, as if severely hurt; and flew some three or four hundred yards farther from the thicket in which we first started it, and dropped again in a piece of thick hill-side coppice. I marked the bird accurately by the top of a pine tree, and off we set in pursuit, I more than half suspecting that the bird was unwounded. Scarce had we entered the covert, when up whizzed the identical bird fresh and sound, from the very brake in which I had marked him, and away like a bullet through the tree tops. So thoroughly convinced was I, that, though I could have killed the bird with ease, I would not fire at it; but to convince my still doubting friend, we walked back to the little tuft in which we first sprung the cock; he promising not to fire if we should again flush her. My dogs were not well in the alders before the bird rose again, and was going away at her best pace, when my friend's shot stopped her, to my infinite disgust. He is a very quick shot, and in the excitement of the moment forgot everything except the game and the fury of pursuit.

Almost at the same moment, old Chance-he was the best retriever I ever saw in any country-picked up from the spot where I had supposed he was snuffing after a field-moise 
a young downy, unfledged Woodcock, less than two inches long.

Clance would carry a hurt bird by the tip of his wing, without ruffling a feather; and though it will hardly be believed, I took the little fledgling from his mouth unharmed, and had the satisfaction of seeing him run away briskly, and hide himself behind a dock-leaf.

That day we shot no more, nor indeed that summer; but before we left Orange county, I went again to the same brake with the old dog, but without a gun, and flushed what I presume to have been the male bird, which, by its simulated crippled flight, again drawing me away from the spot, convinced me that he was watching over his motherless little ones.

Had I needed anything to convince me that Woodcock ought not to be shot in July, that scene would have convinced me; and since that day I have never ceased to advocate a change and simplification of our game laws, which should prohibit the killing of Woodcock until the first day of October; and make that one day the end of close time for all game whatever.

For the present, however, until the game laws shall be altered, and established on a more reasonable and more perma. nent footing, of which I flatter myself there is still a remote hope left to the true sportsman, there is nothing left but to make the best of it,-to take the field ourselves, with the $i i \pi_{0} i \lambda_{01}$, and do our best at the slaughter; nor will I deny that there is much sport in it, though sport which, if men could be induced to forego it, would lead to such results in autumn, as we can now hardly imagine.

This interesting little bird, being properly nocturnal in his habits, is rarely or never seen by day, unless by those who are especially in pursuit of him, and even by them he is found witl, difficulty, unless when hunted with well broke dogs.

At nightfall, however, he may often be seen on the wing, darting athwart the gloom from the dry upland coverts, in: which at many seasons he loves to lie, toward his wet feeding grounds. During the hours of darkness he is on the alert con- 
stantly; by night he seeks his food; by night he makes his long and direct migrations, choosing for this latter purpose foggy weather, at or about the full of the moon.

By day he lies snugly ensconced in some lonely brake, among long grass and fern, under the shade of the dark alder or the silvery willow, and near to some marshy level, or muddy streamlet's brink during the summer; but, in the autumn, on some dry westering hill-side, clothed with dense second-growth and saplings.

In very quiet spots, especially where the covert overhead is dense and shadowy, he sometimes feeds by day; and it has been my fortune once or twice to come upon him unsuspected when so engaged, and to watch him for many minutes probing the soft loam, which he loves the best, with his long bill, and drawing forth his succulent food, from the smallest red wireworm to the largest lob-worm, suitable for the angler's bait when fishing for Perch or the Yellow Bass of the Lakes.

It is by the abundance of this food that his selection of haunts is dictated, and his choice of seasons, in some considerable degree, controlled. On sandy and hungry soils, as of Long Island, for example, he is found rarely in comparison, and never in the large congregations which so rejoice the heart of the sportsman in more favored localities. Still more does he eschew sour marsh land and peat bogs, wherein, by the way, the worm he most affects hardly exists; while on fat loamy bottom lands, whether the color of the soil be red or black, rich with decomposed vegetable matter, he may be found in swarms.

It must be understood, however, that after the young brood have left the parent birds, which departure occurs after the first moult, the Woodcock is a solitary bird, acting and moving for himself alone, although the same causes may draw hundreds of them to one neighborhood, and never flving in flocks or assriciating in anywise with his fellows, until the commencement of the breeding season.

At this period of the year, from July I mean, to the begin uning of the moult, when the bird disappears from among us for 
a while, the young broods are found on the ground in which they are bred.

And there is scarcely any sort of ground, in which the soil consists of black vegetable mould, or rich loam of any kind, and in which there is a sufficiency of water, that is not congenial to him as a breeding place-I except always the depths of the primeval forests, in which he never is found.

The narrowest ravines, down which the merest thread of water trickles among bare gray rocks, provided there is a bed of rich succulent soil in the bottom of the swale, even at the height of 800 feet above tide-water will hold a brood or two; so will the swampy bogs and morasses on the tops of the highest hills; but the favorite breeding ground of the bird is undoubtedly level marsh meadows, interspersed with clumps and thickets of willow and alder, maple groves, growing on swampy land, and warm sequestered vallies.

In South-West Jersey, they are found in the greatest abundance on perfectly open meadows, among bog grass and rushes, in exactly what would usually be called admirable Snipeground; and I have killed them in the neighborlıod of Salem, in considerable numbers, where there was not a tree or bush within half a mile. This approximation of habits between the two kindred species, of Snipe and Woodcock, is very curious and interesting-the former bird, as we have seen above, under certain circumstances and in peculiar districts, betaking himself to the wooded haunts of his nearest blood relation, and the latter, when in a treeless country, making himself at home among marshy levels better adapted to the general habits of his cousin.

On no ground, however, have I ever seen, or shall I, I much fear, ever again see this bird in such multitudes, as on what are called the "Drowned Lands" in Orange county, N. Y. These are a vast tract of level country, surrounding the various branches and tributary streams of the Walkill-it extends many miles in length, and contains every sort of lying-tall open groves, impenetrable fastnesses of brake and thicket, wide reaches of perfectly open bog-meadow, and as wide expanses of open 
plain, covered with rich, tender grass, and interspersed at every few paces with brakes of alders, and willow bushes. The numbers I have seen, on that ground, are incredible. In 1839 I shot over it, accompanied by my friend, Mr. Ward, of Warwick, who then weighed above three hundred pounds, and shot with a single-barrelled Westley Richard's gun; and, in three successive days, we bagged fifty-seven, seventy-nine and ninety-eight Cock, over a single brace of dogs, not beginning to shoot unti] it was late in the morning. On the following year, with a friend from New-York, I shot on the same ground all day the first, and until noon on the second; bagging, on the first, one hundred and twenty-five birds, and, on the second morning, seventy. The first of these days was intensely hot; and the ground became so much foiled by running of the innumerable birds, that, although we had excellent retrievers, we lost, beyond doubt, forty or fifty birds; and at four in the afternoon we were entirely out of ammunition.

I am perfectly satisfied that, if we had been provided with a brace of fresh dogs, at noon, with clean guns, and a proper supply of powder and copper caps, both of which gave out, it would have been perfectly easy, on that day to have bagged from one hundred, to one hundred and fifty couple of Wood cock.

The shooting on that ground is now ended. The Erie railroad passes within ten miles of it, and it is now overrun with city poachers and pot-hunters; besides being shot incessantly by the farmers' boys and village idlers of the neighborhood who have begun to compete with the New York vagabonds ir supplying the markets with game.

I confess that I have often wondered that the owners of these tracts have not had the shrewdness to discover that by enforcing the laws, and prohibiting trespassers, they might annually let the shooting of these ranges for very considerable sums. "The Drowned Lands" are in general held in large farms, and the best shooting is all owned, comparatively speaking, by a very few individuals. I have not the slightest hesitation in saying that 
if some half-dozen or eight farmers, whose land I know, would resolutely put an end to all shooting on their premises, they could readily let the right of shooting to an association of gentlemen, at a price which would put a hundred dollars annually into each of their pockets.

I could find the gentlemen who would give it, and be but too glad of the opportunity; and who, looking forward to enjoyment of the same sport in future years, would neither wantonly annihilate the stock, nor do the mischief to the grass crops, and fences, which continually results from the incursions of the loafers and vagabonds, who compose the great bulk of rural sportsmen. I really should greatly rejoice at seeing something of this sort attempted. Its effect would be most beneficial on the preservation of game generally throughout the United States.

At the beginning of the Woodcock season, to revert to things as they now are, it is an easy matter to find birds, if you are in a good country; and in truth, except in the immediate vicinity of the large cities, there is no difficulty in finding broods enough to amuse a few leisure hours; although it is daily becoming more and more questionable whether it is worth the while of dwellers in the Atlantic cities, to keep dogs for the purpose of Cock-shooting, and to make excursions some fifty or sixty miles inland for sport during the season. A due regard to truth compels me to say that such excursions have ceased to be what they were, "consule Flanco," when General Jackson was first President; yet farther inland there are doubtless still places to be found abounding with the tribe of Scolopax; although from the "Big Piece," and the "Little Piece," from Chatham and the "Drowned Lands," the glory of his house has, for the most part, departed.

In July, then, there is ordinarily but little skill to be displayed in the mere act of finding the birds, for there is nothing to be done but to beat the ground carefully, thoroughly and slowly, wherever there is water and covert. Unless the brood of the season has been annihilated already, or the ground so 
persecuted in past seasons as to have been entirely descrted by the breeders, here they must be found. In this country Woodcock are shot altogether over Setters or Pointers-during the whole sixteen years, which I have passed in the States, 1 have known but two sportsmen who used the Cocking Spaniel, though that is unquestionably the proper dog over which to shoot the bird-and it is obvious that there are many objections to be made to these, in their places, noble animals, as used for covert-shooting. The proper sphere for both Pointer and Setter is the open-the wide, waving, heathery moors, the grassy Snipe-bog, the rich russet stubbles, from which the harvests have been garnered to the farmer's heart-content. To range as wide, as highly, and as dashingly as they can, is their proper vocation, and their highest merit. To work fairly and in full view of their master and of one another, giving plentiful note of the vicinity of game by their actions to the eye, but none to the ear, is the province for which nature destined them, as all their qualities demonstrate.

In order to suit them for wood-shooting at all, one of these qualities has necessarily to be drilled out of them, by early and incessant rating, watching and admonition-I mean their speed, range and dash.

The highest merit a thorough-bred and thoroughly-broke Setter or Pointer can possess in Europe, on his proper ground, and in pursuit of his proper game, is never, unless he be at a dead point, or down to charge, to be within five hundred yards of his master, always beating his ground, head up and stern down, at full gallop. Here in covert at least, where nine-tenths of his work is done, his highest merit is never to be twenty yards distant from him.

He must unlearn his own nature, and acquire that of the Spaniel; in so far, at least, as to substitute unwearied industry, short, continually-succeeding turns, and the closest possible quartering of the ground, for his natural rating gallop. His eye must be constantly on his master, his ear ever alive to bis slightest whistle, which he must obey with the speed of 
light. He must be prepared to back his fellow, oftener at the word "Toho!" than at sight of his point ; for so difficult is the covert in which his duty is done, that I lave more than once seen three several dogs standing within a square of six yards, on one bird, not one of which suspected his comrade's presence. Again, he must be broke to drop where he is when the shot is discharged, instantaneously, and to lie there until commanded to "Seek dead;" when he must draw up to the killed bird, point it, and at the word "Fetch," perform the duty of a retriever.

This it is, which makes a really fine, and thoroughly broke, Woodcock dog so nearly invaluable.

Shooting as we do in this country in thickets overrun with vines, creepers, and cat-briars, to which the densest coppice or covert I ever have seen in England, was open-work, and that too, when every tree, plant and shrub is covered with its most luxuriant summer foliage, it is evident that a dog cannot be visible half the time at a distance of ten paces; and that it is only by his keeping in constant motion to and fro, close before us, that we can in the least make out his whereabout. As it is, with the best broke dogs, it is a common thing to lose them altogether, though perhaps but fifteen yards off; when pointing steadily, and to be compelled either to call them off, or to waste half the day in looking for them.

Another great difficulty in summer Cock-shonting, over Setters, is this, that when the bird is pointed, as he almost universally is, from the outside of a brake inward, it is almost impossible to get a fair shot at him, unless you do so unspurtsmanlike a thing as to hie your dog on, and make him flush his own bird. This cannot be done with impunity for any length of time, even with the best and steadiest dogs; for when once they have become used to this irregular mode of proceeding, although they may stand stock still, and shew as staunchly as possible, under their master's eye, until desired to "hie on!" no sooner will they find themselves pointing out of sight, than they will follow what is surely the bent of their natural instinct, 
kept down by painful instruction, and will dash in and fush their game.

When shooting in company, as one always should do, if possible, especially in July, I have always made it a point, when the dogs were standing, so as to render it likely that the shot would be a ticklish one, to call up my comrade,--birds lie hard in summer, and a word or two, more or less, will not flush them,to place him in the most commanding position, and then plunge into the brake, taking my chance for a snap shot, and up with the bird myself. Having always kept dogs, and having shot principally with friends who did not, it has always been my luck to have the gamekeeper's work, and to be forced to drive through the thick of the tangle, while the others could pick their way along the outskirts, and get open shots. Somehow or other, however, I have generally managed to get about as many shots, and perhaps to bag about as many birds as my neighbors; and, in process of time, I have got into the way of liking the roughand-tumble inside-of-the-covert work. You see more of the dogs' working, and get more, if harder, shots ; and, above all, you acquire what is the knack of covert-shooting, the knack of tossing up your gun instinctively to your shoulder, and stopping your bird in the most tangled thicket, without knowing how you shot him, or whether you saw him at all when you fired, the instant you hear a flap of his wing.

Even when alone, I invariably flush my own bird, never order-ing my dog to go on, even at the risk of losing a shot; though the chances are, that you can generally mark the bird down tolerably well. In this matter I never vary, and I do most strenuously urge it upon all sportsmen, who would have good dogs, and good sport, to neglect and sacrifice all individual shots, all individual, crippled, or killed birds, rather than do a wrong thing themselves before their dogs, or allow them to do a wrong thing uncorrected.

By running in to catch one wing-tipped bird, racing away from your dogs, or by encouraging them to run in and fetch, before you have loaded, you will lose, in all probability, fifty 
birds,-by your setter getting into the way of dashing into the midst of scattered bevies, and flushing them all, one by one, while you are standing with your unloaded gun in your hand, roaring down-charge, and uttering, if you are a little quicktempered, all sorts of imprecations against your poor dog, which, if at all just, you would fulminate against yourself. Nothing is more annoying to me, than to be joined by some country gunner in the field, who, utterly unconscious of wrong, persists in doing things which make your own hair stand on end, and compels you to flog the unliappy quadrupeds for the faults of the stupid biped.

While speaking on this subject, I will quote an observation which I met with the other day, in a capital book, by a right good sportsman, entitled-the book, not the man- "The Moor and the Loch." The truth and force of the remark struck me the moment I read it ; and, although it is not new to the accomplished sportsman, or old dog-breaker, I think I have never seen it in print before ; and I am sure I have seen the fault it reprehends committed a hundred times.

The writer is speaking of "the inveterate.habit, contracted through bad breaking, of running in when the bird drops. This trick is acquired from the breaker's carelessness, in not always making the dog fall down when birds rise, a rule which should never be neglected, on any pretence." Mr. Colquhoun here means, that the dog should be taught to charge, on the bird rising, whether shot at, or not; and unquestionably he is right in the matter. "The steadiness of a dog," he proceeds, "whether old or young, depends cntirely upon its being rigidly observed. I have seen dogs most unmercifully flogged, and yet bolt with the same eagerness every shot. It is easy to see the reason; the dog was followed by the keeper endeavoring to make him 'down'; there was thus a race between them, which should first reach the fallen bird. The plan to adopt with a dog of this description, is when the Grouse," or other game, "drops, and the dog rushes forward, never to stir,-coolly allow him to tear away at the game until you have loaded; by which time be 
will most probably have become ashamed of himself. You will then walk up most deliberately, and without noticing the bird, take the dog by the ear, and pull him back to where you fired, all the time giving him hearty shakes" $-I$ should say, cuts with the whip,- " and crying 'down,' when you get to the spot where you shot from, take out your whip, and between the stripes call ' down,' in a loud voice ; continue this at intervals for some time; and, even when you have finished your discipline, don't allow the dog to rise for ten minutes at least; then, after speaking a few words expressive of caution, take him slowly up to the bird, and lift it before his nose. If this plan is rigidly followed for several shots, I never saw the dog that would continue to run in."

The writer, it will be observed, is here speaking of running in to eat or tear, not to "fetch" his bird ; that being a practice never taught, or allowed, to Pointers and Setters in. England, simply because, being used altogether in the open field, it is as needless there, as it is necessary here. When I first came to this country, I imported a fine young Setter pup, which I had broke by Mr. SANDFoRD, of Newark, whom I consider, in all respects, the best and most intelligent dog-breaker I ever saw, and, on conversing with him on the mode of breaking, I was equally surprised at learning two things, - that Setters, or Pointers, were invariably broke to "fetch," or retrieve dead birds; and that they were always taught to "come in" before charging. I was exceedingly incredulous on the first point; and it was only with reluctance, and after seeing the steadiness with which his dogs first charged, then pointed dead, and then fetched, that I consented to allow "Chance" to be broke to retrieve. On the other point I was firm; and Mr. Sandford haring broken that dog for me, to drop to shot, on the spot, without coming in, was so thoroughly convinced of its advantage, in giving steadi. ness, in avoiding unnecessary words and orders, and in rendering the dog promptly obedient, that he at once adopted the method, and has never broken a dog otherwise since that time.

I must add, that I am equally well satisfied, that to retrieve 
is a necessary accomplishment for a Setter or Pointer in this country; that it would be an advantage everywhere; and that a dog can be precisely as steady fetching every bird, as he can if incapable of so doing.

But he must invariably be made, not only to down-charge, but to point dead, before he is allowed to fetch. If the second duty is neglected, it will be a very little while before the animal begins to rush in at every shot, without charging.

One great difficulty here is, that no one in America having gamekeepers, the hunting of the dog, so soon as he is turned out of the breaker's hands, falls directly on the master-who is very generally, eve if himself a very passably good shot, unacquainted with the methods of dog-breaking, and unqualified by his habits of life, for taking the trouble of going systematically to work with the animal, so as to keep him up to all that he knows, and to prevent him from either acquiring new bad tricks, or neglecting his old teachings. It is scarcely too much to say, that one half of the dogs in the United States, which go out of the breaker's into the master's hands valuable brutes, are, at the end of twelve months, worthless.

I should strongly recommend young sportsmen, when purchasing new dogs, to take an opportunity, if possible, of seeing them hunted several times by the breaker, and of endeavoring to observe his peculiar modes of speech and action with the dog ; and at all events to learn those points of education, on which he insists, in order that they may guide themselves in their own conduct toward the animal thereby, and insist on the animal acting in all respects up to his previous teaching. Old sportsmen, of course, have their own ways of having their dogs trained, and on these they are so trained before buying them. Another thing is worthy of observation-a dog never ought to be lent. I would not lend my dog to a better sportsman than myself-because no two sportsmen hunt their dogs, as I have observed, exactly alike, and I wish my dog to hunt as I want him to hunt, not better than he does, nor worse. It is impossible to imagine the difference of the intelligence of two dogs, 
equally good by nature, the one of which has never been hunted but by one master, and the other by every one whom he has been pleased to follow.

I have taken the opportunity of making these observations on dog-breaking, and dog-hunting, in this place, because in summer Woodcock shooting, above any other phase of the sport, an implicit obedience, great steadiness, and perfect staunchness is required in the dog. In Quail, or Snipe-shooting, you can see your dog the greater part of the time; you can observe his every motion; and can usually, if you are quicksighted and ready-witted, foresee when he is about to commit a fault in time to check him. In summer shooting, woe betide you, if you entertain so wild a hope. You hunt darkling, catching sight of your four-footed companion oniy by snatches, often judging him to be on the point, because you have ceased to hear the rustle of his sinuous movement through the bushes; or because you have not seen his form gliding among the waterflags or fern, so recently as you should have done, had he turned at his regular distance, and quartered his ground without finding game. It is not once in ten, nay! in twenty times, that you see him strike his trail, draw on it, become surer, and stand stiff. You lose him for a moment, look for him, where he ought to $b e$, and find him because he is there, pointing as you expected. A step or two forward, with your thumb on the hammer, and the nail of your forefinger touching the inside of your triggerguard. Still he stands steady as a rock; and you know by the glare of his fixed eye, and the frown of his steadfast brow, and the slaver on his lip, that the skulking Cock is within ten feet of his nose, perhaps within ten inches. You kick the skunkcabbages with your foot, or tap the bunch of cat-briars with your gun-muzzle, and flip-flap! up he jumps, glances, half-seen for a second, between the stems of the alder bushes, and is lost to sight among the thick foliage of their dark green heads, before your gun-butt has touched your shoulder. But your eye has taken in his line-the trigger is drawn, the charge splinters the stems and brings down a shower of green leaves, and 
among them you fancy that you have seen an indistinct something falling helplessly earthward-that you have heard the thud of his tumble on the moist ground. Nevertheless, anxious although you be, and doubtful of your own success, you stir not from the spot. At the report of the gun, your dog couched instantly; you can scarcely see him, so closely has he charged among the water-grass, with his nose pressed into the very earth between his paws.

You drop your butt upon the toe of your boot, if the ground be very wet, and begin to load, rapidly, yet coolly and deliberately. Yes! you have killed him; you may see the feathers floating yonder, in the still murky air of the windless swamp. You half-cock your locks, and apply the caps; and, expectant of the coming order, "Don" lifts his nose wistfully. "Hold up, seek dead !" and carefully, gingerly, as if he were treading upon eggs, knowing as well as you do that the bird is dead, and knowing pretty well where he is, at a slow trot, moving his nose from this side to that, snuffing the tainted air, and whipping his flanks with his feathered stern, he draws onward at a slow trot. Now he has caught the scent, he straiglitens his neck, quickens his pace a little, decidedly and boldly, and stands firm. "Good dog: Fetch." He stoops, picks up the dead bird, by the tip of the wing only, and brings him to you without ruffling a feather. How conscious, how happy, how perfectly aware that he has merited your approbation, that you have both played your parts handsomely, as he hands you the trophy.

Let him snuffle at it, for a moment, if he likes it; he would not touch it with a tooth, for a dog kingdom; but the scent is to him what the aroma of a glass of Lynch's Chateau Margaux of ' 25 is to you,-let him enjoy it, he shall not serve you the worse, for that he looks for his reward.

Here, gentle reader, is what thou art expected to do on occasion. Do it thus, always, and thou art a good sportsman, and a crack shot, not a doubt of it. Do it thus, very often in one day, and thou art having a right good day's sport of it ; 
such as I trust I may have many, before this year has donned the sear of the leaf, which is not as yet green.

Jesting apart, this is the way to do it, both as regards the flushing and shooting the bird, and the management of the dog; and, with respect to the last, I have only to add, that while it is impossible to be too resolute, too firm, and almost impossible to be too strict, if not severe, it is also impossible to be too patient, too deliberate, or too quiet, with a delinquent dog. The least outbreak of temper prostrates its own object. All punishment aims at preveution. If you distract the dog's comprehension of your meaning, the object of the punishment is lost. Remember, too, that the brute knows as well, whether he is punished justly or unjustly, as you do.

A quiet rating, and a gentle pull of the ear, is better than an intemperate and noisy flogging; but when you do flog, let it be no child's play, teasing and irritating without punishing,-when you do flog, flog in earnest.

And this is a day's summer Cock-shooting,-a repetition of this that I have described, varied by those thousand little unforeseen incidents, which render field sports so charming to every sensitive and enthusiastic spirit. First of all, it is pursued in the very loveliest summer weather, when the whole atmosphere is alive with all sounds of merriment and glee,-it is followed among the wildest and most romartic combinations of rural scenery-in the deep, dim, secluded groves, far from the ordinary tread of man, by the reedy and willow-girdled margins of calm inland waters, by the springy shores of musical mountain brooks, in long-retiring valleys high up among the hills, whence we look forth at unexpected turns over wide tracts of woodland scenery-in places where the shyest and most timid of warblers wake their wild music all day long, screened by impervious umbrage from the hot noon-tide of July, where every form of animal life and beauty abounds, unbeheld of ordinary mortals.

And are not all these things a source of pleasure to the true woodsman? Is he not necessarily a lover not of sport only, and 
of excitement-those are the ruder and less genial attributes of his profession-but a lover of nature? To his mere success as a sportsman, I have already shown that a knowledge of the habits and instincts of auimals is necessary; and let a man once set limself to study these, and he has turned already the first page of natural history; and so enticing is the study, that he perforce must persevere. And none can study natural history, without loving nature. The true sportsman, the gentle sportsman, must be in some sort a poet-not a jingler of rhymes, or a cramper of English words into strange and uncongenial measures, a meter of syllables, and a counter of fingers, but a lover of all things beautiful and wild-a meditator, a muser! $\mathrm{He}$ must be, as the old pastorals were, nympharum fugientum amator; and to the very farthest flight of their coy footsteps must he follow them. Were it not for this, the sportsman were but a mere skilful butcher,-out upon it ! there be better things than this in our philosophy!

This it is, with the sense of freedom, the sense of power, of manhood, of unchained and absolute volition, which we feel when our foot is on the mountain sod, our lungs expanded by the mountain air, that makes, in some sort, every man a sportsman.

And then the noonday repose beneath the canopy of some dark hemlock, or tall pine, still vocal with the same fitful murmur which pleasured in Arcadia the ears of old Theocritus-the dainty morsel, rendered a thousand times more savory than your city banquets, by the true Spartan sauce of hunger, the cool draught tempered by waters cooller and clearer, though perchance less full of inspiration, than the lymph of Hippocrene ; the pleasant converse on subjects manifold, over the mild fumes of the composing cigar,-or, if need be, the camping out in the wild woods, the plying of the axe to form the temporary shanty, the kindling of the merry blaze, the rude yet appetizing cookery, the buoyancy of soul caught from all these things, the untutored jest, the untaught laughter; and, last not least, comnosed on the fragrant hemlock tips, which strew the woodman's 
couch, lulled by the murmur of the wind in the never-silent tree tops, by the far plash of falling waters, by the plaintive wailing of the whip-ponr-will, and the joyous revehry of the dewdrinking katydids-the sleep, under the blue vault of the skies, guarded by the winking eyes of the watchful planets only,sweeter and sounder, lighter and more luxurious, than princes catch on beds of eider-down and velvet.

Lo! you now, reader, have not we too caught the inspiration, and ere we knew it, waxed poetical !

One thing alone is wanting to the perfection of summer shooting as a sport-I speak not now of the unfitness of the season for hard exercise, - no season is, in truth, unfit for the display of manhood! - nor of the unfitness of the half-grown broods for slaughter!-and that one thing is, the want of variety in the species of game In autumn, hearty, jocund, brown autumn, the woodman's sport is indeed manifold. Even when his dog has pointed, though he may guess shrewdly from the nature of his movements and the style of his point, the sportsman knows not what may be the game which shall present itself to his skill. It may be the magnificent Ruffed Grouse, whirring up with a flutter and an impetus that shall shake the nerves of a novice; it may be a bevy of quail eighteen or twenty strong, crowding and jostling one another in their anxiety to aroid the danger, and ilistracting his aim by the multiplicity of objects; it may be a full-grown white-fronted Woodcock, soaring away with its sharp whistle high above the tree tops ; it may be the skulking Hare, bouncing among the kalmias and rhododendrons, vulgarly generalized as laurels-they might as well be called cabbages! -it may be Teal or Wood-duck, or if we are in the open, it mav be Snipe, skirring away zig-zag over the rushy level.

This it is which gives so strange a zest to the field sports of an American autumn day, and which renders the autumn shooting of this country the wildest and most interesting of any it has ever been my luck to encounter-of any, I presume, in the world, unless it be that of Northern India, on the lower slopes, and in the plains at the foot of the Himalayah Mountains. 
And with this ends all that is to be said on summer Wood. cock shooting; for the period during which the sport can be followed is of itself brief, not lasting - at the utmost not above a month from its commencement to its termination, by the disappearance of the birds from their usual haunts in this section of the country.

This disappearance of the bird is one of the most mysterious and inexplicable features in the natural history of the Woodcock; and what is very remarkable, it is not in any wise noticed or alluded to by any naturalist with whose works I am acquainted. Neither Audubon nor Wilson appear cognizant of the fact, both speaking of the Woodcock, as if it tarried with us regularly from its arrival early in February, until its departure on the setting in of severe frost.

That this is not the case, is perfectly well known to every sportsman in the country, although very few of these have troubled their heads to consider the circumstances of this short migration, much less to record it. The fact is, that so soon as the young birds of the last brood are full-grown, the Woodcock withdraws for the purpose of moulting, and returns no more until the autumnal frosts have set fairly in, until the meadow grass is crisp, and the leaves sear. A few scattered birds indeed linger in the old places, just enough to prove that there is an absolute change of place on the part of the others of the family, and these only, it is probable, in consequence of some accidental circumstance which has detained them, such as the late ness of their last brood, or perhaps an unduly early moult on their own part, compelling them to remain tranquil, while their congeners are moving.

At all events, the disappearance of the main body is sudden, total, and simultaneous. So much so, that for the five or six earliest years of my residence in America, when matters of business prevented me from absenting myself from the city until the first of August, I was utterly unaware that the " Drowned Lands" of Orange county ever held many Woodcock, although I was in the habit of passing my summers in that immediate

VOL. I. 
vicinity, and had beat the very ground on which I have subsequently killed hundreds, without getting above half-a-dozen shots.

It is in the last week of July, or the first of August, that this disappearance of the Cock, whether from the hill-swales, the larger valleys, or the level meadows, takes place; and after this until the first week in October, it is useless to hunt for them. A few birds can, it is true, at all times be procured, enough to furnish a dainty for a sick friend, or perhaps at a hard pinch to try a dog; but certainly not enough to render it agreeable, or worth the while to go out in pursuit of them. Another fact, going to prove that there is an absolute disappearance or emigration of the bird, at this season, is that on their return, they come in successive flights, tarrying each a longer or shorter time, according to the circumstances of the weather, and then passing onward. This is, I think, conclusive.

When first I began to sport in this country, sume sixteen years ago, there were two theories current among sportsmen, whereby to account for the fact, that in woods, where the birds swarmed in July, they were hardly to be found in August. Both theories, as I have proved to my own satisfaction, are untenable and groundless.

The first was this- " That the bird did not in truth, disappear at all, but remained on his old ground; though, owing to the fact of his being in moult, he gave out no scent whereby the dog could detect him; and from sickness, or inability to fly with his wonted velocity, refused to rise before the tread of his intruding enemy, the man."

This theory is answered in a word. The Woodcock, while in moult, does give out as much scent, is pointed as readily by dogs, does rise as willingly before the point, and is as good upon the table as at any other season. Facts, which are easily proved; since, although the great mass of birds withdraw during August, and do not return before October, a few do still tarry in their old swamps, and may be found and shot, though sn few in number, and at so great an expense of time and 
labor, as to render the pursuit of them toilsome, and productive only of weariness and disappointment.

I have, however, killed them repeatedly, while endeavoring to satisfy myself of the facts which I now assert, so deep in the moult that their bodies have been almost naked, and that they have fluttered up feebly, and with a heavy whirring, on wings divested of one-half the quill feathers; and, in that state, I have observed that the dogs stood as staunchly, and at as great a distance from their game, as usual; and that the birds took wing as freely, though, in truth, half impotent to fly.

Beyond this, it is scarce necessary to point out to an intelligent reader, that if the birds still lay in swarms on their old ground, however scentless, they must, when that ground is hunted closely by true-beating and industrious dogs, be either run up, or turned out of the grass, and caught in the mouth sometimes; which I have never known to happen in all my experience of the field.

The other theory was this, which I have heard insisted on as strenuously as the former, "That the Woodcock, on beginning to moult, betakes himself to the maize or Indian corn fields, and remains there unsuspected until the crops have been lioused, and the cold weather has set in." That a few scattered Woodcock may be found in wet, low maize-fields, along the edge of woods, is true; and it is true, also, that they feed in such situations in great numbers, during the night, previous to their removal; but that they are ever to be found generally, or for any number of consecutive days or weeks in such ground, is an utterly incorrect surmise, disproved by long experience.

I have applied myself carefully to the investigation of this circumstance; and in the last ten years, have certainly beaten a thousand maize-fields thoroughly, with a brace of as good Setters as any private gentleman possessed, at the very period when farmers would tell me "they were as thick as fowls in the corn-fields;" and I have not on any occasion flushed more than three birds, in any one field; nor have I killed twenty-five on such ground altogether. 
Somewhat, I must confess, to my surprise, I have observed within the last few weeks, a long and somewhat elaborate article, in the columns of that admirable journal, the New-York Spirit of the Times, the writer of which apparently quite unconscious of all that has been written on the subject, and seeming to believe that he has made a discovery, brings out anew the old corn-field story. The matter is really not worth talking about. Every school-boy knows that late in July and August a few birds occasionally resort to wet, woodside maize-fields, and every one who has shot fifty summer Cock in his life ought to know, that no number are ever to be found in them, and that he must have immense luck who bags a dozen Cock in all the maize-fields he can beat in a hard day's walk. I would like nothing better than to bet season in and out, against one bird to the square acre-or square five acres, for that matter.

I think the reader will admit that the two theories, alluded to above, are by these facts indisputably controverted.

And now I must expect that it will be enquired of me, "whither, then, do they go? What does become of them ?" To which sage questions it is, I grieve to say, my fate to be unable to make satisfactory reply.

I was formerly inclined to believe, that when the moult is at hand, the Woodcock withdraws to the small upland runnels, and boggy streamlets, which are to be found everywhere among our highest hills or mountains. That the moulting season is the signal for dispersion, and the termination of all family ties between the young and old birds, is certain. From this time forth, until the next February brings round the pairing time, the Woodcock, whether found singly in a solitary place, or among scores of his kind, is still a lonely and ungregarious bird, coming and going at his own pleasure, without reference - undemocratic rascal-to the will of the majority.

In corroboration of this view of the absence of our bird during the early autumn, I was once informed by a gentleman whose word I have no reasnn to disbelieve, that on ascending once to the summit of Bull Hil!, one of the loftiest of the High. 
lands of the Hudson, with the intent of showing the fine view thence to a city friend, he found the brushwood on the barren and rocky ledges, and even on the crown of the hill, literally alive with Woodcock. This occurred, according to his statement, in the beginning of September, when no birds were to be found in the level and wet woods below. He farther stated, that he at first intended to revisi: the hill the next day, with dog and gun, in order to profit by his discovery, but was prevented doing so by casual circumstances, until the frost had set in keenly in the woods. He then climbed the hill, and beat it carefully with dogs, without obtaining one point to reward his labor; and on the next day found the swamps below full of birds.

Not vouching for the truth of this tale, I tell it as 'twas told to me; the teller was a sportsman, and a man of average veracity-that is to say, I should have been inclined to believe any fact he stated, where I could see no interest, on his part, which should lead him to attempt deception. In this case there was no such reason; not even the desire of prevailing in argument, for we were not arguing. I cannot, therefore, well doubt the correctness of his information.

If truly stated, as I believe it to have been, this fact makes somewhat for my former opinion. I have, also, myself, frequently found scattered birds on such hill-tops, and in such mountain-swales, wlile deer-stalking, in August and September, though not in numbers which would justify the belief in a general migration en masse to such localities.

If, however, my half-formed opinion-for it is no more-be correct, the birds are dispersed at this period of the year, and are only to be found, casually, in knots of three or four, and never in greater numbers.

The other, and, on the whole, perhaps more probable suggestion is this: that, after rearing their young, driven by the heat of the weather-or, it may be, by the temporary exhaustion of food on their favorite grounds, they move farther northward as does the English Snipe, yet earlier in the season, not to 
return until the premature cold of northern Canada drives them back, to tarry with us a few months on their way southward.

Should this prove to be the case, the Woodcock, instead of being termed with us a summer bird of passage, must be regarded as a spring and autumnal visitant, like his congener, the Snipe-with this difference, that the Snipe rarely breeds with us, going northward to nidificate, while his fellow-emigrant, our Scolopax, invariably rears his young before going farther toward the frosts of the northern pole.

Of these suggestions my readers must judge whether is the better of the two; one of the two I believe to be the only way for accounting for the Woodcock's short disappearance at this season. For the rest, as I leaned at first to the former, so do I now rather incline toward the latter belief, facts not bearing out the former tu my satisfaction, although I do not think the question has been, as yet, fully tested by experiment.

It is to be regretted here, that this question is yearly becoming, in these districts, more difficult of solution; and I am the more strenuous in noting this emigration, because things may come, ere long, to such a pass, that it will become wholly undistinguishable.

When I first shot in New-Jersey, and in the river counties of New-York, the disappearance of the birds was evident enough; because, up to a certain day, they abounded, and after that, were not. Now, long before the second week of July, the Woodcock are exterminated in their summer haunts for miles and miles around our large cities; too many of them, alas! slaughtered before the season, when scarcely able to fly -when nearly unfit for the table-when a game despicable to the loyal sportsman, and a victim easy to the pot-hunting knave who goes gunning with a half-bred, half-broken cur, and a German fowling-piece, dear at a dollar's purchase.

$\mathrm{Oh}$ ! gentlemen legislators-gentlemen sportsmen,

" Reform it altogether!"

Ob! ye choice spirits, who stood forth, ifter the long, hard 
winter and deep snow-drifts Quail-destroying of 1836, to rescue that delightful little fowl from total extinction, stand forth in likewise now, in protection of the Woodcock. Sufficient for the day is the evil thereof. Railroads are ruining the hopesthe pleasures of the sportsman; our best shooting grounds now swarm, on the first of July, with guns more numerous than birds; the Warwick woodlands, once inaccessible to the pothunter and the poacher, may now be reached for fifty cents; may now be swept clear in a single day; nay, are swept clear of half-fledged younglings, by men, boys, and bunglers, and ruthlessly devoured before the season has set in, by ignorant voracious cockneys.

' Reform it altogether!'

Enact that the Woodcock shall not be slain-shall not be possessed-as Mr. Blunt possessed him-on plate or in stomach, until the first day of October. Every true sportsman-every sportsman whatsoever, will go hand and heart with the lawwill watch and prevent the illegal sale of the bird; and then, ye gods of woodcraft! Sylvans and Fauns! and thou, friend of the hunter, Pan! what sport shall we have in brown October, when the sere underbrush is bare of leaves to mar the sportsman's aim; when the cool dewy earth sends up the odor of the game in fresh steams to the Setter's keen and sagacious nose; when the pure air braces the nerves and fans the brow, delicious; when the full-grown, white-fronted, pink-legged Cock springs up-not fluttering feebly now, and staggering stupidly into the muzzle of the gun, to drop again within twenty yards, but on a vigorous and whistling pinion, wi h sharp-piping alarm note, swift as a rifle-bullet, soaring away through the tree-tops, or daring, devious with abrupt zig-zags, among the thick-set saplings.

Him, no boy can blaze at, his twenty times in half an hour, and slaughter after all with one chance pellet, or happily wearied down without one! Him can no German gun achieve, of cast-iron, scattering its shot over an area of twenty feet, harm- 
less at twenty yards! Him can no cur-dog flush in gun-shot of pot-hunting poucher.

No! gentle reader, him, whether he lies in the tufted fern and wintergreens, or the dry slope of some warm, westering hillside, among second-growth of brown oak and chestnut; whether he wades among the shallow mud-pools, sheltered by fern, dock-leaves, and dark colt's-foot, of some deep maple swamp, it needs the stealthy pace, the slow, cat-like, guarded motion, the instinctive knowledge of the ground, the perfect nose, and absolute docility, which belong only to the thorough dog of the thorough sportsman, to find certainly, and stand staunchly! Him, whether he flap up, seen for one second only, among the leafless stems, and lost the next among the tufted tops of the yet verdant alders; wherher he soar away, with his sharp whistle, far, far above the red and yellow tree tops; whether he pitch now here, now there, sharply and suddenly, among the close saplings, it needs the eye of faith, the finger of instinct, the steady nerve, the deliberate celerity, the marking glance, which characterise the sportsman-the crack shot, who-as poor Cypress averred truly-is born like the poet, not made like the orator-to cut down at his speed; not wing-tipped or leg-broken, but riddled by the concentrated charge, turned over and over in mid air, arrested mercifully by quick and unerring death, and falling with a heavy thud, which tells good things of ten ounces' weight, on the brown leaves of gorgeous autumn.

My words are weak to describe the full charm of this noble pastime-noble, when followed as it should be, in the true animus and ardor of the chase-but most ignoble when perverted to base, culinary, carnal, gluttonous, self-seeking purposesweak are they, when compared with the vivid and heart-thrilling reality-yet even thus, they will have done their duty if they succeed in arousing the attention of the true friends of sportsmanship throughout the land, to this most interesting subject. Certain it is that the Woodcock returns, whether old or young, to the same place where he was bred and where he has reared his 
young, if unmolested. If persecuted and shot off, year after year, on his very breeding ground, and while he was in the very act of breeding, he will desert that ground altogether. Of this, $I$ have seen proof positive. In the immediate vicinity of Warwick, in Orange county, within two miles of the village, there are twenty little woods and swamps, each of which used ten ol twelve years ago to be a certain find in July for two, three or more broods of birds. It was easy shooting and easy marking ground, and year after year I and my party-at that time no one else shot in that region-killed off the whole summer stock, clean. The consequence was, that long before the general shooting of the district was affected by the march of intellect and the growth of railroads, and while birds yet abounded a mile or two farther off, those swamps ceased even to hold a summer brood. Twenty birds killed in a wood, twenty days in succession, injure that wood less as a home for Woodcock than ten killed once in July. Hence, as for fifty other reasons, I say, if we would have Woodcock shooting at all, away with summer shooting-away with all upland shooting, antecedent to the first of October, unless you choose to except Snipe, although for the exception I can see no reason, unless it is that the evil produced by killing them in spring is as yet something less crying, and the diminution of thei: numbers less palpable.

I had the honor to lay a draft of a petition to the New-York legislature on this sulject, before the New-York Sportsman's Club in the course of last winter-1846-7-which was taken up, and the draft printed. I regret to say that, from prudential motives, as it was thought by many good sportsmen, and apprehension of difficulty in getting a sufficiency of signatures, action on it has been pos poned for the present

I am still myself satisfied, that the measure therein proposed, or some other nearly akin to it, is the last and only hope left to sportsmen of preserving any kind of game, but especially Woodcock, among us.

The domestic habits of the Quail, his haunting homesteads, and becoming to some degree a pet of the farmer, and yet 
more, his indigenousness to the land, acts in a considerable: degree as a protection to him. But the Woodcock, who is a mere emigrant, here to-day and away to-morrow, has no domestic friend, no landlord to protect him, and men forget that if spared, he will as surely return to breed in the same wood again, bringing all his progeny with him to increase and multiply, as the tepid winds and warm showers of April and May will succeed to the easterly gales and snow drifts of March, and the leaves be green in summer from the buds which burst in spring.

My game law, such as it is, will be found in the appendix to Upland Shooting. I believe it would be useful as it is, but should any sportsman or any society of sportsmen be able to concoct one better either in practice, or in the probability of success, I and all my friends, and those who think with me on the subject, are prepared to support it. Unity of action is the one thing needful; and that cannot be attained if every man holds out resolutely for his own crotchet.

Let the principle once be affirmed and made good, and the details are of infinitely minor importance. They will follow. For the rest, what is to be done, must be done quickly, or we shall be liable to the ridicule which falls on the tardy faineant who locks his stable door after the horse is stolen.

Three or four more seasons like the two last, and the question will be settled to our hands, and if we do not bestir ourselves now, we shall find ere long that we shall have neither summer nor autumn Cock-shooting within a hundred miles of the scaboard. 


\section{UPLAND PLOVER SHOOTING.}

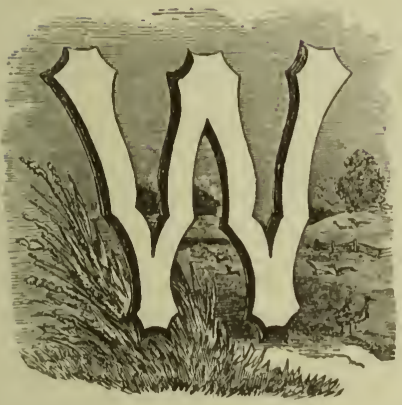

ITH the end of July, all that can properly be called shooting, as a genuine sport, is at an end. The Woodcock, as I have already stated, is no longer to be found, whether he be lying perdu on the mountain tops, or off on a wilder wing for the far north. The Snipe has not yet begun to return from his aretic breeding places; the Quail is still busy with her eggs, or her fledging cheepers; and the Ruffed Grouse, although her young are already two-thirds grown, is protected by the game-laws until the first day of November.

This last protecti n by the way, is as absurd in point of fact, as everything connected with the game laws of the States.

All the varieties of Grouse are early breeders; their young come rapidly to maturity; when full-grown they are as wild as hawks; and at all times, from their own habits, and the peculiarity of the ground on which they reside, they take better care of themselves, than any other species of winged game. The breeding season of these birds commences in May; early in June the young birds can fly; and by the middle of September they are full-grown. There is this peculiarity about them, moreover, that they do not, as all other birds of this rrder, rasores, with which I am acquainted, keep together in broods or coveys until the commencement of the next breeding season; but separate altogether, and ramble about either as single individuals, or in small parties, during the autumn and winter. 
After this separation has once taken place, the birds, buth young and old, are so wild that they will rarely or never lie to be pointed by a dog, unless they are found by chance in some very dense brake or grass-grown thicket, in which they cannot run; and consequently there is no chance of having any sport with them, after they have once ceased to keep company. This, I think, they invariably do, before the law permits that they should be shot. Consequently, although I have often been in regions where they abound, I have never found it worth the while to go out to hunt for them especially. They are a bird of a very rambling disposition, here to-day and miles off tomorrow, frequenting the roughest and most inaccessible mountain-sides, evergreen thickets, and woods of hemlock, pine or red cedar; and I have never seen, and never expect to see the place where a sportsman can be sure of getting a dozen shots over points, or even half that number, in a day's hard walking. Add to this, that if the Ruffed Grouse be the particular object of pursuit, there is no chance of finding any other species of game, unless it be a few Hares; for the haunts of this solitary and mountain-loving misanthrope are too wild and rude for the domestic Quail, and too arid for the Woodcock.

In autumn shooting, stragglers are often met on Quail ground, in low thickets, bog-meadow edges, and the like, and then they afford good sport, and often make a great addition to the bag; but the only way is to take them as you find them, and if you find them, be thankful; but never deviate from your regular line of beat in order to find, or to follow them; if you do, sure disappointment awaits you. The best day I ever had with Ruffed Grouse, was in the low, dense thickets on the edge of the Big Piece, in New-Jersey, in the winter of 1837; when there were a vast quantity of Quail in that region; but I had not the least expectation of finding more than a chance straggler or two of the Grouse. With a friend, however, I bagged eight brace of these birds, fairly pointed, which I consider great sport, as I have never before or since seen an opportunity of doing a quarter of the work, though I have taken long journeys 
for the especial purpose of getting this sport in perfection. If the law authorized the shooting them in September, or at the latest on the first of October, there are many districts of the country, where the Ruffed Grouse would afford great sport to those, who would take the trouble to pursue them into their fastnesses, which requires considerable strength and activity.

In the meantime, however, while there is no legitimate upland shooting to be had-by legitimate, I mean that, which is followed with dogs, whether Setter, Pointer or Spaniel, in a legitimate and scientific manner-there comes into play, at the very critical moment, the "Bartramian Sandpiper," better known as the "Upland Plover"-_ "Grass Plover"_- "Field Plover," or "Frost Bird"- which as far as a bonne bouche for the epicure goes, is inferior in my judgment to no bird that flies, unless it be the Canvass-Back; and there, with the Chancellor, I doubt! As a game-bird, and object of pursuit, I do not myself care about him, the modus operandi does not suit my book, or entertain me ; nevertheless, there is much skill displayed in circumventing, or as Major Docherty would say, surrounding this wily bird, and as frequently a very large number may be brought to the bag, it is with some persons a very favorite sport.

This bird, which by the way is not a Plover, though very nearly allied to that species, is stated by Mr. Aububon to arrive in the Middle States, early in May, to reach Maine by the middle of that month, to breed from Maryland northward to the Sashatchewan, and to winter in Texas and Mexico.

It is shot, in the Eastern and Middle States, from Massachusetts to Pennsylvania, during the months of August and September, and in fact, until it is driven southward by the frosts; although it is worthy of remark, that it is also killed abundantly so far south as the neighborhood of Charleston, S. C., as early as the middle of July. The great majority of the birds shot in these districts is certainly not composed of those only which are bred here; but is continually swelled by flocks coming down successively from the north-eastward, where I 
imagine they breed, in far greater quantities than within the confines of the States.

On their arrival here they frequent, wherever such exist, wide, upland downs or moors, covered with short, close turf; and are found in greater numbers in Rhode Island, in the vicinity of Newport, than in any other district with which $I$ am acquainted; although from the aspect of the country, the nature of the soil, and the quality of the grass lands, I cannot doubt but that they must exist abundantly along the Atlantic coasts of the State of Maine. Comparatively speaking, there are few sportsmen in that region, as is the case in all new countries, where men hunt for profit or for provision, not for sport, and where the pursuit of the larger animals is so common and so well rewarded, as to render the shooting of birds on the wing rare, and in the eyes of the community rather ridiculous. The consequence of this is, that the capabilities of the country in a sporting view, are unknown; and the species of game, to be found in it, almost certainly lost to the sporting world.

In June, 1840, I saw several of these birds, with young, in the immediate vicinity of the city of Bangor ; and I have little or no doubt that, were proper means taken, great numbers might be procured at the proper season in that region.

'The Field Plover is abundant in the Boston markets during the season; and I believe they are sufficiently common to afford amusement to the sportsmen of that country, though I am not aware in what parts of the State they are most frequent.

On the plains in the vicinity of Hempstead, Long Island, they used to abound; and they still frequent that country, although not nearly so numerous as they were some years since. In New Jersey they are very rare, owing to the nature, I imagine, of the soil, and the face of the country; for these birds are the least maritime of their race, and never, I think, frequent salt marshes, or water meadows of any kind; of which most of the low lands in New Jersey consist, while its hills are not open sheep-walks, but rocky and wooded fastnesses, equally unfit for. this Sandpiper's abode. 
Where vast unenclosed plains are not to be found, this bird loves to haunt large hill pastures, fallow-fields, and newly ploughed grounds, where it finds the various kinds of insect food to which it is so partial,- - grasshoppers, beetles, and all the small coleopterous flies common to such localities, in the grass lands-and worms, small snails, and the like, on the fallows.

The Upland Plover is a shy and timid bird ; and, on foot, it is, for the most part, nearly impossible to approach it. It feeds on ground such as I have described, in small companies-they cannot be called flocks, for they do not usually act in concert, or fly together, rising, if they are startled, one by one, and each taking its own course, without heeding its companions-this, by the way, I have noticed as a peculiarity of all the upland scolopacida, none of which fly, so far as I have ever observed, in large bodies, wheeling and turning simultaneously, at a signal, as is the practice, more or less, of all the maritime Sandpipers, Tattlers, Plovers, and Phalaropes. While running swiftly over the surface of the ground, they utter a very peculiar and plaintive whistle, exceedingly mellow and musical, which has the remarkable quality of appearing to be sounded close at hand, when it is in reality uttered at a very considerable distance. It is this note which frequently gives the first notice to the sportsman, that he is in the vicinity of the bird; and it also gives him notice that the bird is aware of him, and out of his reach; for no sooner is it uttered, than the Sandpiper either takes wing at once, or runs very rapidly to some distance, and then rising, swerps round and round in aërial circles, and alights again out of distance. If wing-tipped, or slightly wounded, it runs so rapidly as to set pursuit at defiance, and then squats behind some clod of earth, or tuft of grass, to the colors of which its beautifully mottled plumage so nearly assimilates it, that it cannot be distinguished, without great difficulty, among the leaves and herbage.

I have only shot this Sandpiper myself, on a tract of upland pasture and ploughed land, near to Bristol, in Pennsylvania, known as "Livingston Manor," where I found the birds very 
plentiful, and in excellent condition, during the inonth of August, in the year 1844. The country being closely enclosed with stout timber fences, it is impracticable either to drive up to them in a two-wheeled carriage, which is by far the preferable mode of pursuing them, or to stalk them on lorsehack; although I am of opinion that great sport might be had there with a pony that could fence well, and stand fire steadily. The men who shoot them for the market there, build bough-houses, in which to lie hid, or conceal themselves in the corners of maize-fields, or behind any casual hiding-places the country may offer, while their companions scatter about the ficlds, driving the birds to and fro, and rendering them, of course, exceedingly wild; yet a considerable number are shot thus, as they fly over their concealed enemies. This mode of proceeding is, of course, unendurable to the sportsman. By the aid of Eley's wire cartridges, red and blue, of No. 6 shot, however, I contrived to get moderately good sport, walking about in pursuit of them, and taking my chance at those driven over me by other parties. I, one day, bagged sixteen birds thus; but it would have been a hundred to one against getting a single Sandpiper, with loose shot; as I am certain that not one bird fell within fifty yards of me.

This Sandpiper flies very swiftly, and when on the wing shews like a very large bird, owing to the great length of its sharp-pointed wings. At first siglit, you would suppose it to be as large as a pigeon, altllough its body is not, in truth, very much larger than that of the common Snipe, or intermediate between that and the Woodcock, while the extent of its wings from tip to tip exceed either of these, by nearly one-fourth. Like many other species of wild birds, this Sandpiper is extremely cunning, and appears to be able to calculate the range of a fowling-piece with great nicety; and you will constantly find them sitting perfectly at their ease, until a few paces more would bring you within shot of them, and then rising, with their provoking whistle, just when you believe yourself sure of getting a crack at them. In the same manner they will circle 
round you, or fly past you, just out of gunshot, tempting you all the time with hopes that will still prove false, unless you have some such device as Eley's cartridges, by which to turn the shrewdness of this cunning little schemer to its own destruction.

In Rhode Island, where alone the sport is now pursued systematically, the mode adopted is this, - the shooter, accompanied by a skilful driver, on whom, by the way, the whole onus of the business rests, and to whom all the merit of success, if attained, is attributable, is mounted in what is termed in New England a chaise, that is to say, an old-fashioned gig with a top. In this convenience, he kneels down, with his left leg out of the carriage, and his foot firmly planted on the step, holding his gun ready to shoot at an instant's notice. The driver, perceiving the birds, as they are ruming and feeding on the open surface, selects one, according to his judgment, and drives round it rapidly in concentric circles, until he gets within gunshot of it, and perceives by its motions that it will not permit a nearer approach. He then makes a short half turn from it, pulling the horse short up, at the same instant; and at that very same instant, for the Sandpiper rises invariably at the moment in which the chaise stops, the shooter steps out lightly to the ground, and kills his bird, before it has got well upon the wing. In the timing of all this various work, on the part of the driver and the gunner, there is a good deal of skill requisite, and, of course, a good deal of excitement. But the real sport, and the real skill, are both on the part of the driver, whose duty it is to deliver his marksman as nearly as possible to the game, yet never to run the thing so close, as to allow the Sandpiper to take wing before he has pulled up. The difference in the judgment and skill of drivers is immense; and there is one gentleman in New York, a well-known, and old friend of the public, who is said to be so infinitely superior to all others, that the gun in his chaise, even if it be handled by the inferior shot, is sure to cume off the winner. It is not unusual, I am told, to bag from twenty to twenty-five couple of these delicious birds in a day's sport, 
in this manner, and I have heard of infinitely greater quantities being brought to bag.

The record of some almost incredible number, killed by three guns, was published last year in the Spirit of the Times, and by well-known sportsmen; but I have never tried the sport myself, and cannot therefore speak to it. I am told, it is vastly exciting and amusing,-but I have been told the same thing about lying flat on your back in a battery, off Fire-isłand Inletand I can only say, judging from analogy, that it may be very well for once or twice, or to kill a few hours when there is no other sport to be had, but that it must be awfully slow work, as compared with any sort of field shooting, on which the instinct and intelligence of dogs can be brought to bear. To see them work is, I think, more than half the battle.

After all, any shooting-except shooting sitting-is better than no shooting; and I have no doubt, if I were at Rhode Island, in the proper season, I should be found chaising it, as eagerly as any body else. I am sure I do not know why I should not, since older, and I dare say, better sportsmen than myself swear by it.

This, then, is the connecting link between the autumn and spring shooting of the Uplands. For those who like them, Bay shooting, at all the varieties of Plovers, Sandpipers, Tattlers, Phalaropes, and Curlews, known along shore as "Bay Snipe," is to be had, in full force, everywhere from Cape Cod, or further eastward, to Cape May, during the months of July, August, and September; and, in the end of August, Rail shooting commences on the Delaware and adjacent rivers; but of these I shall treat in their places,-since the former must be regarded as Coast shooting, and the latter cannot be classed with Upland sport, although it is only pursued inland.

With Plover shooting, therefore, the sports of the summer months end; and, with the month of October, the jolliest, hearriest month of the whole year, despite of what Mr. Bryant says of "the melancholy days" of autumn, the real season has its commencement; and thereafter the woodlands, the stubbles, and the mountain's-brow, are the true sportsinan's Paradise 


\section{A U T UMN COCK SHOOTING.}

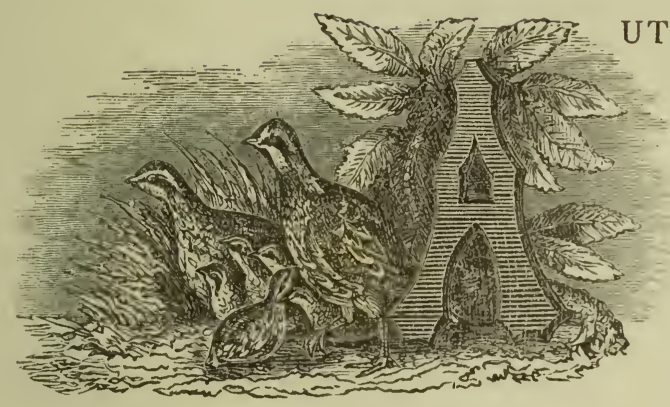

particular month of the season.

Its commencement is regulated by the return of the $W$ oodcock, after its brief August migration; and, the period of that return being uncertain, and dependant on the state of the weather, and other influences, with which we are not fully acquainted, the sportsman has only to bide his time, and take the season as he finds it.

In truth, the variation of the autumnal season is in this respect very great, as regards both the Woodcock and the Snipe. I have shot both of these birds together, in considerable numbers, on the same ground, so early as the 12th or 15th of September; and again, in other seasons, neither the one nor the other bird have made their appearance until so late as the middle of October.

As a general rule; however, I should say that Woodcock begin to return to the Atlantic States, in ordinary seasons, about the middle of September, and the Snipe about the first of Octi- 
ber,- - the latter bird being for the most part a few days behind his congener.

It is very well worthy of remark, both by the sportsman and the scientific ornithologist, that on their return in the autumn, neither the Woodcock nor the Snipe are found precisely on the same ground, which they use in spring; and I am inclined to believe, that a more thorough investigation of this fact, might lead to the acquisition of more knowledge than we possess at present, concerning the causes of the migration of our various birds of passage.

In my articles on spring Snipe, and summer Cock shooting, I have observed that at these seasons the two birds frequently appear to change their habits and haunts mutually ; the former being very often found in low brushwood, and among dense briar patches, and the latter, even more commonly, on open, rushy, water meadows, without a bush or particle of covert in the vicinity.

In no respect does this ever happen in the autumn. I have seen no instance myself, nor have I heard of any from the most constant and regular country sportsman, who have the best opportunity of noting such peculiarities, of the Snipe ever resorting even to the thinnest covert on wood-edges, much less to dense coppices and tall woodlands, in the autumn. Nor have I ever seen a Woodcock on open meadow in that season.

In Salem county, in New Jersey, this latter fact is very strongly demonstrated; inasmuch as during the summer the birds are hunted entirely, and four-fifths of them killed, on what would elsewhere be called regular Snipe ground, or in small brakes along the dykes and river margins; and there is no finer summer Cock ground than this county, in the whole State.

In the autumn, on the contrary, when the bird seeks other localities, there is little or no covert, such as he loves, to be found in Salem, and of consequence, there is little or no autumn Cock shooting to be had in the southern district of New Jersey.

The Snipe, on his arrival, betakes himself at once to the same ranges of country, and the same meadows, as in the spring; 
and, with the sole exception that it is entirely useless to look for him in coppices, or along springy woodsides, as I have re-. commended in wild weather in spring, his haunts and habits are precisely the same.

He is more settled, not being now hurried in point of time, or busied about the pleasures of courtship, or the cares of nidification. He lies harder before the dog, does not fly so far when flushed, and feels little or no inclination to ramble about, but adheres steadily to one feeding ground, unless driven away from it by persecution, until the hard frosts of winter compel him to betake himself to the rice-fields of Genrgia, and the muddy margins of the warm savannah.

Moreover, the weather itself being at this time steadier, and less mutable, the birds are much less often forced to move from one part of the country to another, by the fitness or unfitness of the ground. In spring one year the meadows are too wet, and another perhaps too dry,-both conditions being at times carried to such an excess, as to drive the birds off altogether, from the impossibility of feeding or lying comfortably. In the autumn this is rarely, if ever, the case ; and although autumn shooting is, of course, in some degree variable-Snipe being more abundant one year than another-it never has occurred, within my observation, that the flight passes on altogether without pausing, or giving some chance of sport, more or less, as is not very unusually the consequence of a series of droughts or rains in the spring.

The Woodcock, on his return from the northward, or his descent from the mountain-tops, never, as a general rule, returns precisely to the same feeding grounds which he prefers in summer, during the extreme heats, but appears to prefer dry hillsides, sloping to the sun, southerly or westward, and to choose woods of young saplings, or sprouts, as they are commonly called in this country, tall, wet maple groves, and second growth of oak, adjacent to brook or meadow feeding grounds, rather than the dense coppice, and that variety of brakes and intervales, or glades, whirh he loves the best in July. This pecu- 
liarity renders him a more agreeable object of pursuit at this - period of the year, the rather that he is now found often in company with bevies of Quail, and that almost invariably the latter bird, when flushed in the stubbles where he feeds, flies for shelter to the very covert most haunted by the Woodcock.

All this will, however, vary more or less, according to the nature and face of the country; for where there is excellent feeding and breeding ground, not interspersed with the ferny hill-sides, overgrown with young, thrifty, thickset woodland, Cock do not desert the region, but are found almost in the same haunts as in summer.

And where that is the case, the sportsman may note this distinction, that whereas in summer, when he has once killed off clean the whole of the one, two, or three broods, which frequent a small piece of corpice, or swamp thicket, it will be utterly useless for him to beat it again, he may now, day after day, kill every bird on a piece of gond feeding ground, and will still each succeeding morning find it supplied with its usual complement.

I first learned this fact in Orange county, where, within half a mile of the tavern at which I put up, there is a small, dry, thorny brake, with a few tall trees on it, lying on a sort of island, surrounded by a very wet bog meadow, and half encircled by a muddy streamlet, overhung with thick alders, the whole affair, brake, meadow, and all, not exceeding three or four acres.

I knew the place of old as a certain summer-find for a single brood of Cock. In October, on the first day of my visit to the country, I beat this brake, at throwing off in the morning, and bagged eleven fine fall birds-being four or five more than I expected-two birds went away wild without being shot at, and could not be found again. On the following day, having finished my beat early, and it not being above a mile out of my way home, I thought I would try to get the two survivors, and was much and most agreeably surprised at bagging nine birds, all that were flushed, on the spot. 
Boing quite certain that these were new coiners, and the brake being a very pretty and easy place in which to get shots, and mark birds, I beat it regularly, either going out, or coming home, every day during my stay in the country, and bagged upon it, in all, sixty-three birds in six successive days.

This is now very many years ago, but I noted the fact frum its singularity at the time; and I have since observed, that in certain highly favored places, this may be regularly looked for; and I would never recommend a sportsman, shooting late in the autuinn, particularly after the nights have begun to be frosty, to decline trying a likely piece of ground, a second, or even a third or fourth time, because he has already swept it clear of Woodcock. It does not, of course, follow of all ground whatsoever; but of all that ground which is the most beloved by the bird, it is unquestionably true that it will be filled, and refilled, many times in succession.

This is certainly a curious fact, and one for which it is difficult to account, by any reasonable mode of explanation. The succession of so many birds, is in itself singular, it not being at all apparent where is the reservoir from which the current is supplied. It was not, in the case I have named, from other woods in the neighborhood, of slightly inferior excellence, as feeding ground, for these were not deserted; and, if we suppose that the fresh supplies came in consecutively from the northward by long flights, how should they have been able to time themselves so exactly, as to come on the very nights when the haunt was vacant, and at their service?

On the other hand, if we adopt the idea that the descent is only from the neighboring mountain tops, why should these wait patiently until the others were killed off to their hands, instead of pouring down into the place in a body, and there remaining uutil the supply of food, which renders it so favorite a haunt, should be exhausted?

Such, however, is invariably the case in such localities, and I never but once in my life observed anything like a flock of these birds. That once, in a very wet place, on the edge of a heavy 
swamp, where a large spring, which never freezes, bursts out and percolates through the vegetable soil for a distance of a hundred yards, or a little more, before gathering itself into a single channel, I saw at least a hundred birds rise within three minutes. It was very late in the season, the 6th or 8th of November, and sharp frost had already set in, and it was so late in the afternoon that it was almost dark. I was shooting with a friend, who had a young dog which could not be controlled from running in; and all the birds were flushed at two rises, each of us getting two double shots. The Woodcock settled down all over the large swamp, but it was too dark to follow them; and the next morning, it having been an intensely hard black frost at night, not a bird was to be found in the country.

Had we come upon that flight earlier in the day, and with old, steady dogs, the sport might have been incalculable.

I have always believed, however, that to be an instance of actual migration; and I am well satisfied all those birds had dropped in, from a long flight from the north, whence they had been expelled by the severe cold, with no intention of stopping longer than to recruit themselves by a single day's repose. After that night no more birds were seen in that part of the country, until the breaking of the ensuing winter.

One other point appears to be worthy of remark, with regard to the autumnal migration of Cock, on their way southward, namely, that sometimes, particularly when the winter sets in unusually early and severe on the sea-board, and south of the mountains, the flight of Cock come down all nearly at once, and in one direction, avoiding whole ranges of country, and absolutely swarming in other regions. A few seasons since, when the northern and river counties, so far down as Rockland, were covered with snow, which lay two or three days, in the first week of October, no more Woodcock were found that autumn in that district, or in Eastern New Jersey, quite down to the sea, while they literally abounded on the eastern side of the Hudson, and were killed in profusion throughout Westchester, and even within a few miles of New York city. 
The cause of this, I suppose to be explicable thus, - that there is, in fact, always a two-fold migration of Woodcock in the autumn, that of the birds bred in these districts, which, liaving absented themselves during the moult, return immediately, that over, to the vicinity of their resting-places, and remain throughout the autumn, - and that of the birds bred very far north of us, which tarry at the north so long as the weather will permit, and then visit us for a few days, more or less, according to the state of the country and the temperature, but never make any protracted sojourn with us.

In such a case as that which I have mentioned, the home-bred birds are probably driven southward at once by the temporary local snow-storm, while the northern flights, not liaving been forced to move, tarry till the last, and then hurry off, pitching only for a single day to rest themselves, and resuming their progress every nighit.

Woodcock and Snipe both, it is hardly necessary to observe, are in a great measure nocturnal birds, and almost invariably make all their long voyages, and usually even their casual trips from one feeding ground to another, between sunset and sunrise. I have occasionally seen Snipe travelling high in the air, in small whisps, during the day time in dark foggy weather with small rain falling: but I have never known Woodcock to move their quarters, unless violently aroused, until it is almost too dark to distinguish them on the wing.

The weather, in which both these swift passengers love best to roam, is dull, hazy, and sometimes even rainy, and that commonly on the breaking of a north-easterly storm. This is particularly the case with the Snipe, and in the spring. In fact, I have never known them abundant on the meadows until after two or three days cold heary rain, and to there having been no such storm this present year, I attribute, in a great measure, the extreme scarcity of Snipe.

It is a little singular, however, that, while these birds prefer thick and hazy weather, they almost always choose moonlight nights, and fly most when the moon is near the fill. When 
the sportsman is so fortunate as to find himself favored wits that must delicious to the senses, and most luvely to the eye, of all weather, which we know as Indian Summer, at the full of the Octoler moon, he may count himself almost certain of finding the coverts well stocked with Woodcock. I have frequently acted on this indication myself, and, in spite of being warned by letters from the country that Cock had not come on, have set out from the city, relying on the combination of the purple haze with the full October moon, veiled in soft silver for the nonce, and have rarely been disappointed of good sport.

In all other respects, the pursuit of Woodcock, the mode of hunting them, and the style of killing them, difier in nothing now from the methods to be used in summer. The birds are, of course, far stronger on the wing, as they are now full grown, and instead of dodging about in the bushes and dropping within twenty yards of the muzzle of a gun just discharged, will soar away over the tree tops, and sometimes fly half a mile at a stretch.

The difficulty of killing them, is therefore increased, although the absence of the green leaf affords a fairer view of them, and the man who makes a large bag must depend more on snap shots than on fair chances over steady points.

In this place it will not be improper to insert a slight notice and description of the mode generally adopted for the killing of Woodcock in Louisiana, Mississippi and the other Southwestern States, by what is termed "Fire-hunting."

This practice is resorted to, in some degree, as a matter of necessity, owing to the fact that, in these regions which are the favorite winter home of the bird in question, he frequents during the day only the most impracticable cane-brakes and morasses, from which it is only by dint of the severest labor that he can be dislodged.

Until very recently no other mode of shooting Woodcock was practised at all in these states, as it was regarded as impossible to pursue them with any success during the day time in their gloomy and difficult fastnesses. Of late years, however, 
as might have been expected, it has been demonstrated by good sportsmen, that Cock can be killed over Setters-Spaniels would doubtless be yet preferable-in those states as elsewhere, and the correct, legitimate and : portsmanlike method of hunting them witl dogs is, of consequence, coming into vogue, soon, I doubt not, entirely to supersede the "Fire-hunting" system, which although it may be good fun enough, for once o: twice, can only be regarded as a species of poaching, or pothunting; palliated or perhaps in some sort legitimatized by the necessities of the case.

Throughout this region, as I have said, during the day this more than half nocturnal bird is not to be seen at all without the confines of the dense and tangled brakes on the edges of the deep bayous and morasses, never flying abroad into the open, and contenting itself with nibbling the mud, and picking up a little chance food in its lurking places.

No sooner is it dark, however, than out the Woodcocks come by thousands from their fastnesses, and, pitching down on all sides in the old fields and maize-stubbles, apply themselves to nibbling and boring in the soft, rich loam for their succulent worm-çiet.

Hereupon the fire-hunt commences-with gun and game-bag, powder-flask and sliot-pouch, and all appliances and means sccundum artem, the sportsman sallies forth; but no silky-haired, high-strung, sagacious Setter, no satin-skinned, rat-tailed, obedient Pointer follows his master's heel. In lieu of Don or Sancho, an old, crafty, grizzle-pated, merry negro, comes forth, equipped with the brazen vessel of a warming-pan, or the like instrument, set erect on a pole of some ten or twelve feet in length, filled with light wood, pine knots, or such like bright, burning combustibles.

Arrived on the feeding ground, a light is applied; the quick fuel sends out a broad, ruddy glare; and, as the bearer slowly circumambulates the field, a circle of intense lustre is shed for ten yards around him, rendering every object more clearly visible than at noon-day. The shooter walks close to the fire- 
bearer, on his right hand, and ever and anon as the circular glare passes along over the surface of the ground, his eye detects the Woodcock, crouching close to the earth, and gazing with its full, fascinated eye upon the strange illumination. The next instant up it springs, dizzy and confused and soarirg upward toward the light. It is seen for a second, and then is lost in the surrounding darkness; but of that one quick second the sportsman takes advantage; and by a snap shot cuts him down, with a light charge; never killing a bird at above ten paces distant, and often bagging his hundred in a single even.ng's work.

This mode of Cock-shocting, arises, as it is evident, ex necessitate rei, and may for a while be sufficiently exciting. It must, however, lack all that variety, which is the great charm of our northern shooting; variety, which arises from the working of the emulous, obedient, and well-trained dogs, in observing whose exquisite instinct, fine attitudes and beautiful docility, me judice, lies half the pleasure of field sports; and which, together with the lovely scenery, the brisk, breezy air, and the exulting sense of pers nal independence, and personal power, springing from these and from the glow of cheerful exercise, renders them to active, energetic and enthusiastic minds the first of pleasures, and almost a necessary relief from the dull monotony of every-day existence.

This brings us to Quail shooting, and to what is the climax of all our field sports, that mixed, wild, autumn shooting, in one day of which, the laborious woodman may kill on one range, Quail, Woodcock, Ruffed Grouse, Hare, Snipe, and some two or three varieties of Wild Duck.

I have had many a good day's sport in many countries, but above everything that I have ever seen, or expect to see again, give me a day of rough and tumble autumn shooting, such as it was ten years ago in Orange county, and such as it may perhaps be again, for a short time, when the Erie railroad shall first give us access to the southern tier of counties. Me judice, there is nothing like it in the wild world. 


\section{QUAIL SHOOTING.}

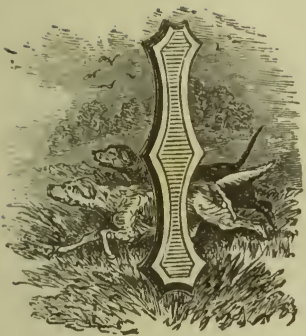

HAVE already, under my list of Upland Game, given a full description of this lovely little bird from the pages of Audubon and Wilson.

Both of these authors lean to the southern fashion of calling this bird a Partridge. Now the truth of the matter is simply this, that the bird in question is properly and accurately neither one nor the other, but a distinct species, possessing no English name whatever. The ornithological name of the Partridge is Perdix, of the Quail Coturnix, of the American bird, distinct from either, Ortyx. 'The latter name being the Greek word, as Coturnix is the Latin word, meaning Quail. It is, of course, impossible to talk about killing Ortyxes, or more correctly Ortyges, we must therefore, perforce call these birds either Quail or Partridge.

Now as both the European Partridges are considerably more than double the size of the American bird, as they are never in any country migratory, and as they differ from the Ortyx in not having the same woodland habits, in cry and in plumage; while in size, and in being a bird of passage, the European Quail exactly resembles that of America; resembling it in all other respects far more closely than the Partridge proper-I canno for a moment hesitate in saying that American Qualu is the correct and proper English name for the Ortyx Virginiana, and I conceive that the naturalists who first distinguished him from the Quail with which he was originally classed, sanction this 
English nomenclature by giving him a scientific title directly analogous to Quail, and not to Partridge.

I should as son think myself of calling the bird a Turkey as a Partridge, and I shall ever hold that the question is entirely set at rest, and that the true name of this dear little bird in the vernacular is American QuaIL ; and his country has better reason to be proud of him, than she has of many of her sons who make much more noise in the world than our favorite BobWhite.

While on this subject, I may observe-for the benefit of our northern sportsmen, many of whom I have heard positively assert that the Quail is not migratory-that every where west of the Delaware he is as distinctly a bird of migration as the Woodcock, and the farther west the more palpably so. Why he loses these habits wịth us of the Middle States I cannot guess, nor has any naturalist so much as alluded to the fact, which is nevertheless indisputable.

It will be seen at once, from the foregoing description, that our American Quail is a most beautiful little bird; but his beauties do not consist merely in his plumage, but in his gait, his pretty pert movements, his great vivacity, his joyous attitudes, his constant and cheerful activity.

$\mathrm{He}$ is in all respects the most social, the merriest, and most amiable of his tribe. During the breeding season, he alone, of the gallinaceous tribe, makes wood and mead resound with his shrill, merry whistle, whence our country folk have framed to him a name Bob-White, from some fancied similarity of sound, cheering his faithful partner during the toils of incubation.

Afterward, when the bevies are collected, as he runs from the huddle in which he has passed the night, he salutes his brethren, perhaps thanks his Creator, for the pleasant dawn, with the most cheerful noise that can be fancied, a short, quick, happy cheeping, "and seems to be," to borrow the words of the inimitable Audubon, I quote from memory alone, "the happiest little creature in the universe." 
The Quail is not only the most sociable of his tribe in reference to his fellows, but is by far the most tameable and friendly in his disposition as regards the general enemy and universal tyrant, man.

In the winter season, when the ground is so deeply covered with snow as to render it impossible for them to obtain their customary food, the seeds namely of the various grasses, which they love the most, or the grains which lie scattered in the stubbles, they come naturally into the vicinity of man's dwellings; and it is by no means an unusual sight to perceive them running about among the domestic fowls in the barn-yard, and flying up, if suddenly disturbed, to perch under the rafters of some barn or out-house, seemingly fearless, and confident, in such seasons, of protection.

During the whole of last winter, I had a bevy of thirteen birds, lying within three or four hundred yards of the room in which I sit writing, under the shelter of a rough, wooded bank, whereon I fed them with buckwheat after the heavy snows had fallen; and they became so tame, that they would allow me to approach within twenty paces of the spot where they were fer, rumning about and picking up the triangular seeds, perfectly unconcerned at my presence. As soon, however, as the spring commenced, and the bevy separated themselves into pairs, their wild habits returned upon them; and I have seen no more of my little friends.

The Quail pairs in the montl of March, or even earlier, if the winter has been a mild one, and the ground at that period is free from its snowy winter covering; if, on the contrary, the spring is very late and backward, his courtship is deferred until April.

As soon as he has chosen to himself a mate, the happy pair retreat to wide, open, rushy meadows, where the conformation of the country affords them such retirement, among the tussocks of which they love to bask in the spring sunshine. Where the land lies higher, and is broken into knolls and gulleys, you will find them at this season on the grassy banks beside some shel- 
tered hedge-row, or along the green and shrubby margin of some sequestered streamlet; but never in thick woodlands, and rarely in open fields.

Most birds, so soon as they have paired, proceed at nnce to the duties of nidification and the rearing of their young; it scems to me, however, that the Quail spend some time in pairs before proceeding to this task; for I have frequently seen them in pairs so early as the twentieth of March, yet I have never found the Hen sitting, or a nest with eggs in it, during spring Snipe shooting, though I have often flushed the paired birds on the same ground with the long-billed emigrants.

I have never, indeed, seen a Quail's nest earlier than the middle of May, and have often found them sitting as late as the end of July.

Their nest is inartificial, made of grasses, and situate for the most part under the shelter of a stump or tussock in some wild meadows, or near the bushy margin of some clover field or orchard. The Hen lays from ten to two-and-twenty eggs, and is relieved at times, in hatching them, by the male bird; who constantly keeps guard around her, now sitting on the bough of the nearest tree, now perched on the top rail of a snake fence, making the woods and hills resound with his loud and cheery whistle.

The period of the Quails' incubation, I do not know correctly ; the young birds run the moment they burst from the egg; and it is not uncommon to see them tripping about with pieces of the shell adhering to their backs.

The first brood hatched, and fairly on foot, the hen proceeds at once to the preparation of a second nest; and committing the care of the early younglings to her mate, or rather dividing with him the duties of rearing the first, and hatching the second bevy, she devotes herself incessantly to her maternal duties.

So far as I can ascertain, the Quail almost invariably raises a second, and sometimes, I believe, even a third brood in a single season. Hence, if unmolested, they increase with extraordinary rapidity, when the seasons are propitious. It is, however, 
equally certain that, under other circumstances, they suffer more severely in this region of country, than any other bird of game; and that in unfavorable seasons they run great danger of being altogether annihilated. The fear of this result has led to what I consider hasty and inconsiderate legislation on the subject.

Long severe snows, when the country is buried many feet deep, and he can procure no sustenance, save from the precarious charity of man, famishes him outright-heavy drifts, especially when succeeded by a partial thaw, and a frost following the thaw, stifles him, in whole bevies encased in icy prisonhouses.

It is the peculiar habit of this bird to lie still, squatted in concentric huddles, as they are technically called, composed of the whole bevy, seated like the radii of a circle, with their tails inward, so long as snow, sleet, or rain continues to fall. So soon as it clears off, and the sun shines out, with a simultaneous effort, probably at a preconcerted signal, they all spring up at once with an impetus and rush, so powerful, as carries them clear through a snow-drift many feet in depth; unless it be skinned over by a frozon crust, which is not to be penetrated by their utmost efforts. In this latter case, where the storm has been general over a large extent of country, the Quail are not unfrequently so near to extinction, that but a bevy or two will be seen for years, on ground where previously they nave been found in abundance; and at such times, if they be not spared and cherished, as they will be by all true sportsmen, they may be destroyed entirely throughout a whole region.

This was the case especially, through all this section of the country, in the tremendous winter of 1835-'36, when these birds, which had been previously very abundant, were almost annihilated; and would have been so, doubtless, but for the anxiety which was felt generally, and the energetic means which were taken to preserve them.

Another peril, which at times decimates the breed for a season, is a sudden and violent land-flood in June and July, which drowns the young broods; or a continuance of cold, showery, 
weather, in those and the preceding months, which addles the eggs, and destroys the early bevy. This is, however, but a partial evil,-as the Quail rears a second brood, and, as I have before observed, sometimes a third; so that in this case the number of birds for the season is diminished, without the tribe being endangered.

The open winters, which have prevailed latterly, have been exceedingly favorable to the increase of this beautiful and prolific little bird. Never, perhaps, have they been more abundant than they were last autumn; and as the winter has been in all respects the most propitious ever known, there having been scarcely a single fall of snow of any magnitude, and no crust in any instance to molest them, there is every likelihood of a fine stock next autumn being raised throughout the Middle States.

A little judicious legislation-a little energy combined with careful consideration of the subject, and mutual concession on the part of true sportsmen, might possibly now preserve this very interesting native American from the total extinction that threatens him.

It is quite clear, that neither idle good wishes, nor fuineant despair, will do so. One bad winter, and the present state of things, will settle the question for us,-but the wrong way!

Unlike the young broods of the Woodcock, which are mute, save the twitter with which they rise, the bevies of Quail appear to be attached to each other by tender affection. If dispersed by accidental causes, either in pursuit of their food, or from being flushed by some casual intruder, so soon as their first alarm has passed over, they begin calling to each other with a small plaintive note, quite different from the amorous whistle of the male bird, and from their merry daybreak cheeping; and, each one running toward the sound, and repeating it at intervals, they soon collect themse ves together into one happy little family, the circle of which rumains unbroken, until the next spring, with the genia! weather, brings matrimonial ardors, pairing and courtship, and the hope of future bevies.

If, however, the ruthless sportsman has been among them, 
with his well-trained Setter and unerring gun, so that death has sorely thinned their numbers, they will protract their little call for their lost comrades, even to night-fall; and in such casesI know not if it be a fancy on my part-there has often seemed to me to be an unusual degree of melancholy in their wailing whistle.

Once this struck me especially. I had found a small bevy of thirteen birds in an orchard, close to the house in which I was passing a portion of the autumn, and in a very few minutes killed twelve of them, for they lay hard in the tedded clover, and it was perfectly open shooting. The thirteenth and last bird, rising with two others, which I killed right and left, flew but a short distance, and dropped among some sumachs in the corner of a rail fence. I could have shot lim certainly enough, but some undefined feeling induced me to call my dogs to heel, and spare his little life; yet afterward I almost regretted what I certainly intended at the time to be mercy ; for day after day, so long as I remained in the country, I heard his sad call, from morn till dewy eve, crying for his departed friends, and full apparently of memory, which is, alas! but too often another name for sorrow.

It is a singular proof how strong is the passion for the chase, and the love of pursuit, implanted by nature in the heart of man, that however much, when not influenced by the direct heat of sport, we deprecate the killing of these little birds, and pity the individual sufferers,-the moment the dog points, and the bevy springs, or the propitious morning promises good sport, all the compunction is forgotten in the eagerness and emulation which are natural to our race.

It is also worthy of remark, that in spite of his apparent tameness at peculiar seasons, and his willingness to be half naturalized, the Quail has hitherto defied all attempts at perfect domestication, and has, I believe, never been known to breed in confinement,- - this peculiarity going, perhaps, some way to render him fair game.

Of all birds, in this or any other country, so far as I know 
from personal experience, or have heard from others more competent to pronounce on the sulject, the Quail is the most difficult both to find and to kill with certainty.

Bred in the open fields, and feeding early in the morning, and late in the afternoon, on buckwheat and other grain stub. bles, during all the rest of the day, the bevies lie huddled up together in little knots, either in some small thorny brake, or under the covert of the grassy tussocks in some bog meadow.

The small compass that each bevy occupies, while thus indolently digesting their morning meal, renders it very easy for the best dogs to pass within six yards of them, without discovering their whereabout; and, consequently, even where the country is well stocked with bevies, it is not an uncommon thing to toil a whole day through, without raising one-half the birds which have fed in the morning on your range.

Again, when flushed in the open, these birds irnmediately fly to the thickest and most impenetrable covert they can find; and in some sections of the country in which I have shot, Maryland especially, that covert is of such a nature, so interwoven with parasitic creepers, cat briars, and wild vines, and so thickly set with knotted and thorny brushwood, that they can run with impunity before the noses of your Pointers or Setters, and that, without the aid of cocking Spaniels, which are little used in the United States, they cannot be forced to take wing.

These birds have another singular quality, which renders them exceedingly difficult to find, even when they have been accurately marked down after being once flushed. It is, that for some considerable time after they have alighted, they give forth no scent whatsoever, and that the very best dogs will fail to give any sign of their presence.

Whether this reten: $:$ on of scent is voluntary on the part of the bird, it is very difficult to ascertain. It is a very strange power, if it be voluntary, yet not more strange than many others of the instincts possessed by wild animals.

There is one thing which would lead to the conclusion that it is voluntary, or at least that the bird is conscious of the fact. 
This is, that under these circumstances, the birds will not rise at all, until they are literally almost trodden upon. It was very long before I could bring myself to believe in the existence of this singular power of suppression; and very many times, after having marked down a bevy to a yard in favorable ground, and having failed to start them, I have left the place, concluding that they had taken to the trees, or risen again unseen by me, when I am satisfied, had I waited half an hour before proceeding to beat for them, I might have had good sport. I will here ohserve, that although Quail do, beyond doubt, occasionally take the tree, in certain localities, and in some kinds of weather, still so far as my experience goes, they do so rarely when pursued, and then rather in consequence of some particular habit of a single bevy, than of any natural instinct of the bird.

Once again-and I have done with the difficulties of findingparticular bevies, endowed with that singular craft, which approaches so very nearly to reason, that it hardly can be distinguished therefrom, will fly when flushed, invariably for many days and weeks in succession, to some one small out-of-the-way nook, or clump of briars, so long as that nook is undiscovered, thus baffling all attempts to find them.

In one instance, while shooting in the vale of Warwick, with an old comrade, when returning home late in the evening, and when within two hundred yards of his hospitable tavern, he said he thought he could start a bevy by the stream side, where he had observed that they often roosted.

Accordingly we went to the place, and had not gone ten yards into the bogs, before the Setters, of which we had three, all came to their point simultaneously, and a large bevy of sixteen or eighteen birds jumped up before them. We got in our four barrels, and killed four birds handsomely; and marked the birds over the corner of a neighboring wood, lowering their flight so rapidly, that we had no doubt of finding them on a buckwheat stubble, surrounded by thick sumach bushes, and briary hedges, which lay just beyond the grove.

We hunted till it was quite dark, however, without moving 
the birds. On going out the next morning, we drew the bogs blank, and it became evident that they had roosted in the place, wherever it was, to which they had flown, on being disturbed.

We set off, therefore, again in that direction, hoping to find them on their feeding ground, but spent the greater part of the morning trying for them in vain.

We then took our dogs in a different direction; and after a day's sport-whether good, bad, or indifferent, I do not now remember-again found our bevy in the same bogs,- -killed a brace of them only, in consequence of their rising wild, and the evening having grown dark, and again marked them over the same wood corner-the birds literally flying over the top of the very same crimson maple which they had crossed the previous evening.

It was too late to look farther after them that night, and I knew that they would not be in the bogs on the following morning,-we took, therefore, a different beat, and heard no more of my bevy.

On the third day, however, being piqued by the escape of these birds, I determined to spare no pains to find their hidingplaces. We proceeded accordingly to the bogs, the first thing in the morning, found them before they had quitted their roost, and drove them for the third time over the top of the same red maple.

These birds, be it observed, were on my old companion's own farm, every inch of which we knew thoroughly, and on which there was not a brake, or tuft of rushes, likely to harbor a single bird, much less a bevy, with which we were not acquainted.

We spent four hours beating for these birds again in vain, and left the ground in disgust and despair.

In returning home, however, that night, we recrossed the same fields; and expecting nothing less than to find game, I was walking down the side of a snake-fence, along which grew a few old apple-trees, with my dogs pretty well fagged at my heel, and my gun across my shoulder. Sud kenly out of the 
mouth of an old cellar, over which a cottage had stood in past days, up whirled a bevy of Quail, and away over the very same tree-top, but now in the opposite direction.

On examining the cellar, the inside of which was filled with briars and weeds, we found conclusive proof in the numerous droppings of the birds, that they had been in the constant habit of sitting therein, attracted thither probably, in the first instance, by the apples which had fallen into the hollow from the trees overhead.

It was as yet but early in the afternoon, and we were so near home that we got fresh dogs, and went to work at them again in the bogs, where we originally found them. Some time had elapsed, and they had run together into a single knot, rose again very wild, and flew directly back to the old hiding-place.

Thither we followed them at once, flushed them therein, proving most unequivocally that they had always lain perdu in the same small spot, and drove them out into the open.

It was too dark by this time to pursue them any longer; and afterward, though we found them constantly in different parts of the bog meadow, neither as a body, nor as single birds, did they ever betake themselves again to the cellar for refuge.

Had I not accidentally blundered on that place, when think ing of anything rather than of the birds, I might have hunted for a month over the ground without finding them. From the cavity, and the narrowness of the mouth, a dog might have gone within a yard of it without scenting them; and I have no doubt that mine had been more than once within that distance of them.

And here I have done with the difficulty of finding, which by the way is not the least step toward killing our bird.

It is, however, little less difficult to kill when found, than to find in the first instance. When first flushed the bevy rise with such a whirring and tumultuous noise that they are very apt to flutter the nerves of a young sportsman; and if they rise very close to the shooter, I have often seen even tolerably good shots discharge both their barrels fruitlessly, from doing so much too quickly. 
This is not, however, by any means the difficulty to which I allude, as an old and steady shot is of course presumed to be proof against such tremors; and in the open field, under ordinary circumstances, ought, generally, to kill his double shot out of every bevy that is pointed and flushed within fifteen or twenty paces.

The case becomes, however, altogether different after the birds have become scattered in coppice, or yet worse, in high saplings, the very thickest part of which they most affect, after being once disturbed.

There is no bird, which I have ever seen that can in the slightest degree compare with the Quail for the rapidity with which it takes wing, and the short space which it requires to get under full headway. It really is wonderful to observe the extraordinary speed and command of wing with which this bird will dart through the most intricate and tangled brake, yet I have never seen a single instance of their flying foul of a tree or getting entangled in a thicket, as will sometimes happen to ine Ruffed Grouse, and much more frequently to the European Pheasant.

The Quail flies, as I have said, with extreme rapidity in a direct line, rather ascending for the most part, but rarely or never dodging and pitching to and fro like a Snipe or Woodcock. It has a habit likewise if not pointed, of lying hard until you have passed it, and then flirting up behind your back; in which case your first intimation of its whereabout is the sharp whirr of its wing, and you must bestir yourself hastily indeed, yet coolly withal, and you must have the eye of instinct, and the nerve of steel, to cut him down handsomely under such circumstances.

It may be added to this catalogue of difficulties, that in flying from you, as the Quail does in a great majority of cases, he presents to the aim of the sportsman a vital centre little larger than a cent piece, with two radii formed by the slender pinions, in which small target four or five shot must be lodged to bring him down with any certainty; so that it will not appear 
runarkable if, with a gun that scatters its charge, even a grood shot miss this bird even at a short range; and that at thirty or forty paces the very best guns, aimed with perfect precision, fail frequently of killing clean.

The Quail is a very brave bird, moreover. He will carry off a great quantity of shot, if not lodged in a vital part, and will frequently, even when mortally wounded, particularly if shot through the brain or heart, and going before the wind, fly till life leaves him in mid air, and even after that will be propelled by the rapidity of his previous motion and the buoyancy of his still extended wings, for many yards farther in a descending line.

A singular instance of this occurred to myself while shooting in the Highlands of the Hudson, nearly opposite to West Point, with two friends, in November, 1839. We were beating a bare field on one of the lower hills of that chain, in which were several shallow ravines lying nearly parallel to each other, pointing transversely downward.

I was in the lowest of three gulleys with a brace of dogs, and perhaps a hundred yards in advance of my companions, each of whom, with one dog, was making good another parallel gorge.

The wind was blowing keenly and coldly on our backs, and before us lay a long range of open fields sloping steeply toward the river, with a piece of young woodland, bounded by a stone wall on the hither side, beyond them.

Finding no game myself, I was suddenly put on the alert by the quick shout, " mark! mark!" from behind, somewhat to my left; and in the next moment a large bevy of birds, which had been raised by my friends and circled round my back, passed me within twenty paces to the right.

It struck me at the time, that I never had seen birds fly so fast ; they had already traversed sufficient space to have gained the full momentum of their own velocity, and had in their favor all the impetus that the swift wind, directly before which they were flying, could give them. I was shooting with a gun that 
carries its shot very closely, and that loaded with Ely's patent. cartridge, which are propelled full one-third farther and more strongly than loose shot-and to conclude, I was perfectly cool, and making allowance for the distance and velocity of the birds, fired both barrels. To my infinite disgust neither bird fell, and I need not add, to the infinite mirth of my companions, who accused me of missing two perfectly fair shots in the open.

I replied, thereby greatly increasing their merriment, that I had not missed either bird, and that I had hit both in front of the wing, that is to say in the most vital part of the body; at which they laughed ineffably; but in the end it turned out as usual that the last laugher has the best of it.

For, to proceed, we marked the bulk of the bevy into the woodland I have mentioned, at least a quarter of a mile down wind, and followed them thither.

But on arriving at the stone wall which bounded it on the nearer side, both my dogs stood almost simultaneously, and immediately retrieved the two birds I had shot at, perfectly dead, but both warm, and both bleeding from the bill.

The shots I fired were the first shots fired that morning, consequently they must have been my birds, and they had flown after being mortally struck, above a quarter of a mile, and would probably have flown considerably farther, skimming close to the ground, had not the stone wall, against which, I have no doubt, they struck, brought them up at last. From curiosity I kept the two birds apart, and on picking them found in one five, in the other seven, No. 8 shot in the neck and breast in front of the wing.

The comparative size of No. 8 shot to a Quail, is about that of grape shot to a man, and to judge of the tenacity of life and muscular motion, we must imagine a man running half a mile at the top of his pace with seven grape shot, as big as a moderate sized plum, through his neck and the cavity of the sternum -a thing palpably impossible!

We will now proceed to the consideration of the means of overcoming these difficulties, and the best method of carrying 
on the pleasant and exciting pursuit of this beautiful little bird.

From the greater difficulty of finding and killing Quail, it follows of course that a greater combination of qualities in the dog with which we hunt them is required.

For Snipe or Woodcock shooting, the latter especially, which is pursued in very close covert for the most part, we require only a dog with good hunting qualities, under excellent command, broke to hunt extremely close to his master, and never to go beyond the range of his sight. Indeed if he do not hang upon the stale scents, and potter where birds have been but are not, a dog for Woodcock shooting can hardly be too slow or too steady.

Now all these qualities are essential likewise to the Quail $\mathrm{dog}$, and without these qualities the sportsman can have no success when he has attained the first object of his morning's work, the driving and scattering his birds from open grain or grass fields into covert wherein they will lie hard, and rise singly, which constitute the only circumstances under which, north of the Delaware and Potomac, it is possible to bag many Quail.

Yet this is far from all that we require in a Quail dog; for as we are compelled to seek for our birds in the open feeding grounds, while they are running in the early morning, and as our day's sport mainly depends on finding a considerable number of birds during that short time, which ends at the latest, by ten o'clock in the morning, and earlier in warm, sunny days, it follows that the more ground we can get over in a given time, the greater the chance of success.

We require therefore that our brace of dogs while beating open ground should have dash and speed enough to run almost like foxhounds on a breast-high scent, heads up and sterns down, quartering the field from fence to fence in opposite directions and crossing each other midway-that they should be so staunch and steady as to allow the shooter to come up to them from five or six hundred yards' distance, without breaking their poir t-and lastly that they should be under command so perfect 
that on getting int, covert they shall cross and re-cross their ground fifty times, never budging twenty yards from the feet of their master, and working as slowly as the slowest Cock-dog.

It will be seen at once that such a combination of opposite qualities must needs be very rare; and so rare is it, that for every hundred of good Woodcock-dogs which I have seen in this country, I have not seen ten equally good on Quail.

I shall not touch here on the comparative and much disputed excellence of the Pointer or the Setter, except to observe that personally I greatly prefer the latter; while I admit that for persons who shoot but rarely, and who do not like the trouble of constant supervision of their dogs, I had almost said constant dog-breaking, the Pointer is the more suitable companion.

I have, however, seen, indeed have owned Setters, which in all points of steadiness might have competed with the staunchest Pointers, and which were as careful and under as good command on the first, as on the last, day of the season.

I will now suppose that the sportsman has arrived at his shooting ground, and taken up his quarters in his snug country tavern for the night, previous to commencing operations in the early morning over a brace of good dogs, Pointers or Setters, at his own option.

First then, let him see his dogs, which we will suppose have run some part of their journey afoot, well suppered on mush, or suppawn of Indian-meal, or oatmeal, seasoned with a little salt, but no meat, which injures the nose; and well bedded on clean wheaten straw. Next let him sup lightly, limit his potations to the second glass, and eschew a second pipe or cigar. Let him to-bed early, that he may sleep well and rise refreshed and with steady nerves.

These are small matters doubtless-but it is the observance of small matters that makes great men in any line, and in our case, good sportsmen.

Lastly, let him assure himself before retiring to rest, that his sheets are dry and well aired, no inconsiderable matter to him who would avoid rheumatism. If he be the least in doubt, and 
be wise, he will discard the suspected linen, and turn in between the blankets.

On getting up in the morning, all ablutions duly performed, it will be necessary to provide for the needful operation of breaking fast; and this must neither be neglected, for no man can take exercise with impunity on an empty stomach; nor must it be done too luxuriously, for as certainly no man can walk well, or fast, or keep it up long, on an overloaded one.

Here is my method.

I have found it impossible to get out early enough to do execution from any country tavern, if one waits until a hot breakfast is prepared. My method, therefore, is to take with me a cold ham, or a cold hunters' round, and to have the table laid over night, in addition to that, with bread, butter, and cold milk, on which, for my part, I can breakfast very satisfactorily.

This done, if you know the country, go to the place where are the most and likeliest grain stubbles lying near to good woodland, or coppice covert, and beat them regularly, in such a manner that the woods shall be down-wind of your beat. I.et your dogs, however, beat every field up-wind, by which means they will scent their birds one-third farther than if you go downwind.

Look especially to the sides of the fields, particularly if they are bushy; Quail do not affect the middle even of the stubbles on which they feed.

If your dogs trail a running bevy, never run or hurry them. 'They are, if you do so, nearly sure to flush them wild. Be, on the contrary, very steady yourself, and cry "Steady! steady! Toho!" words to which dogs should be accustomed early. If they point firmly, and are so very staunch that you can depend on them, it is not a bad plan to make a wide circuit, and get a-head of the bery, which even if wild and running, will often squat on finding itself enclosed between the dog and the gun, and thus afford good shooting.

If you drive a bevy of Quail into good covert, be not in haste to follow it. It will stay there, be sure; and you will find them 
far more certainly after half an hour has elapsed. For myself, I have found it the best plan, where woods are small, and the covert thick, to go on beating the open fields, without following the bevies at all, in the first instance, marking them down carefully when they rise, until the feeding and running hour has passed,- - then to follow bevy after bevy, whither you have seen them alight; and knowing their whereabout, if not the exact spot where they lie, the dogs will soon find them.

Otherwise, if one wastes the morning in killing off one bevy, by the time he has done with it, the birds will have crept away into their hiding-places, and he may hunt the wood-skirts, and brush-holes, all day along, without finding another, even where they abound, unless he blunder upon one by chance.

During the heat of the day, if one have not found birds in the morning, although it is pretty much chance work, bog meadows, brown bushes on southerly and westerly hill-sides, old pastures with much bent and ragwort, and the skirts of coppices, are generally the best ground, though in some regions they will be found in large open woodlands.

In the afternoon, soon after four o'clock, the bevies again begin to run and feed, and in this part of the day they will frequently be met running along the grassy margins of streams which flow through pasture-fields, whither they resort to drink, or at least to crop the wet herbage.

So good is the chance of sport at this time, that I would urge it strongly on the sportsman who has failed of finding his bevies on the feeding ground in the morning-if he know that there is a fair show of birds in the district-not to persist in wearing out himself and his dogs, by fruitless toil in the heat of noon, but rather to await the cool afternoon, when he will very often make up for lost time, and make a heavy bag when circumstances have looked least auspiciously.

I have now set my sportsman fairly in the field, and shown him how best he may find his birds,-more is beyond my means.

A crack shot must in some sort be born; but most persons, 
with good eyesight, and steady nerves, may attain to respectahility, if not excellence, in this gentlemanlike and manly art.

To this end, practice and coolness are the great desiderata. Rules, I think, avail little, if anything. I have seen men shoot excellently, who closed one eye to take aim-excellently who shot with both open,-never, however, I must admit, decently, who shut both-not, by the way, a very uncommon occurrence with beginners. I have seen men again shoot excellently, carrying their guns at full cock,--excellently, who never cocked either barrel till in the act of firing.

There is, however, one thing to be observed,-no man can shoot well in covert, or at snap shots, who follows his bird with his gun, or dwells on his aim-the first sight is always the best; and it is deliberate promptitude in catching this first sight which alone constitutes-what my poor friend, J. Cypress, Junior, used to call the rarest work of nature-a truly cool, truly quick, crack shot.

With regard to hunting dogs on Quail, there is a great deal to be said; and in nothing is the true and thoroughbred sportsman more distinctly marked from the cockney pot-hunter, than by his skill, temper, and success, in managing his four-footed companions.

Quail shooting, as the most difficult of all shooting, and requiring the greatest natural qualifications, and most perfect training in the dog, demands also the greatest science in the person who hunts the dog.

The great desiderata here are, first, to know precisely what a dog ought to do,- - and, second, to make him do it.

In this country, far more sportsmen fail in the first-in England more in the second particular.

It were scarce too much to say, that four sportsmen, in their own opinion, here, out of five, know so little what are the requisite performances and capabilities of a dog, that within twelve months after buying a perfectly well-broke dog, they permit him to lose all he has ever known, merely from failing to exercise his abilities, and punish his eccentricities. 
$A_{s}$ in all rther tuition, reward and punishment must both be brought into play; but it is a great thing to remember that, while a dog should never be allowed to disobey an order, or to commit a fault unpunished, it is well neither to harass him by unnecessary commands, nor to tempt into faults by over exaction.

Moreover, a dog cannot be managed with too little shouting. He should be accustomed always to obey the whistle; and he will very soon learn to understand the meaning invariably attached to any combinations of that sound, turning his head to observe the gesture of your hand, by which he may be directed to beat this way or that, to back his fellow's point, or to downcharge-the signal for the two latter duties being the same,the hand held aloft, with an erect arm, open, with the palm facing the dog, the fingers closed, but the thumb extended. This motion ought to arrest a dog at the top of his speed, the instant his attention is called to it, as suddenly as if he were shot dead ; and the advantages gained from the strictest enforcement of the rule, are too palpable to demand further comment.

If, therefore, a Setter, or Pointer, is broke to lie down immediately to charge, on the firing of a shot, and to turn his head at every whistled call of his master, thereafter obeying one or two simple gestures, the necessity for roaring like a bull of Bashan, as is the practice of most dog-breakers, and all cockney sportsmen, will be entirely obviated. The advantages of which will be, that you will not flush four-fifths of all the game within hearing, nor drive your fellow sportsmen crazy, if they happen to be blessed with nerves; and not render yourself as hoarse as a waterman on a hackney-coach stand, by bellowing out orders, which your dog, nine times out of ten, cannot hear, being to windward of you.

A shrill ivory whistle should always be hung from the buttonhole of the jacket, and a heavy dog-whip invariably carried in the pocket; but, although neither of these, in their way highly useful implements, should be suffered to enjoy a sinecure, it is almost unnecessary to observe that of the last, even more than 
of the first, the real utility will be greatly diminished by too frequent application.

I shall have farther occasion to speak of the management of dogs, and indeed of the habits and mode of shooting Quail likewise, under the head of "General Autumn Shooting," which will follow the few remarks I shall proceed to make on Pinnated and Ruffed Grouse shooting, as practised apart from the pursuit of other game.

VOL. I. 


\section{RUFFED GROUSE SHOOTING,} VULGO, - PARTRIDGE SIIOOTING.

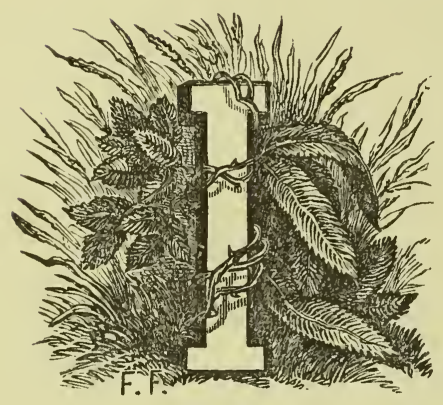

$\mathrm{T}$ was my misfortune onceonce only, gentle reader-in my life, to be seduced into undertaking an excursion very late in the season, a few days only before Christmas, into the interior of Connecticut, for the especial purpose of shooting the Ruffed

Grouse, or as it is there termed, Partridge.

I went on the representation of a friend, who while Cockshooting on that ground, early in the autumn, before the leaves were down, had moved an immense number of these birds, which were then in broods with the old hen. He assured me, as he fully expected would prove the case, that we should certainly get twenty or thirty fair shots each, daily; and in consequence I looked for great sport.

The result was, that, although we had two brace of as good Setters as any in the country, and fagged steadily and resolutely during four successive days, we bagged seven birds between us ; two only over points ; and certainly did not fire altogether,' at snap shots and long range, above ten or eleven shots. On other occasions, once or twice, I have been persuaded, contrary to my opinion, to go out of my way to beat for Ruffed Grouse, or to devote a day to their especial pursuit, but I never in any one case have been successful. 
The Ruffed Grouse, after the broods have separated and left the hens, are the wildest and most wary birds I have ever pursued, when the woody nature of the haunts which they affect is taken into consideration. They have also the most rambling habit of any American game-bird, except the Turkey; it not being an uncommon thing for the single birds, or the small companies into which they sometimes form themselves, to wander on the foot, without taking wing at all, ten or twelve miles, at a stretch, over rough hills and through deep woodlands. Add to this, that their favorite resorts are the steep ledgy s'des of rocky hills, covered with thick wood, and that generally of evergreens, as pine, hemlock, or red cedar, with an undergrowth of the great mountain rhododendron, commonly known as laurel. It is the characteristic of this sort of woodland, that, while the foliage is very thick and intricate above, on a level with the breast and eyes of the sportsman, it is for the most part perfectly open and clear below; so that while the hunter has the greatest difficulty in seeing his birds, the birds have none whatever in seeing him or his dogs. They consequently start on the full run-and he who has tried to secure one when wing-tipped or slightly wounded, without the aid of dog, knows what pace that is-the moment the sportsman enters the wood; and after keeping the dogs trailing and roading on their scent for a mile or two, either flap up unperceived into a tree, or take wing at a hundred yards' distance; and in either case get away unshot at. On this account, they are the most trying bird to the temper of a dog that possibly can be imagined, as it is comparatively speaking of very rare occurrence that they will lie to be pointed, and flushed over the point.

The exception to this rule is where they are found, which is rarely the case, in low, swampy thickets of heavy covert, in level country. In such places, if you have the luck to find them, you are almost certain of great sport; for, where the ground is thick and tangled at the bottom, they will squat, 
finding themselves unable to run, and will lie, on such occasions, till they are literally kicked up.

I have never, in all my experience of shooting in this country, seen this occur but twice; and in fact the bird is so seldom found in lowland country, that I consider it utterly useless to go out in pursuit of Ruffed Grouse, except as an adjunct with other birds of bolder and freer wing.

One of the instances I have alluded to above, is perhaps not unworthy of notice, as I believe it to be almost unique; for I have met no sportsman who has seen any thing of the sort occur with the Ruffed Grouse, though with the Prairie Hen it often happens. It occurred during early autumn shooting, on the second or third of November, immediately after the law of New-Jersey permits this bird and the Quail to be shot; and Woodcock had not as yet forsaken the country. I was beating for game in general, but rather with a view to Cock than any other bird, in a long, narrow swale, between a steep ridge and an open meadow, along the edge of which my companion was walking, while I myself made good the whole width of the alder coppice with my dogs. Suddenly both the Setters came to a dead point at a small patch of thick briars and brambles close to the meadow fence, and, on my walking up to them, finding that nothing moved, I took it for granted that it was a Hare, and called out to my friend to look out, as I would beat it out to him. On kicking the briars, however, to my great surprise a very fine Ruffed Grouse, a cock bird, rose within ten feet of me, and flew directly acruss me toward the hill Unfortunately, my friend fired at the bird across me, contrary to all rules of sport manship, so that two charges were wasted on this bird; for immediately, at the report, three more birds rose out of the same brake, two of which flew across him over the open meadow, both of which he must have killed had he reserved his fire, as he should have done, while the third follow ed the cock across the swale to the riage, till I stopped him.

Taking it for granted that all the birds must have gone now, four barrels having been fired directly over the thicket in which 
they lay, I made some observation to my companion abont his rashness in firing; when three more birds whirred out of the same bush in quick succession, and of course got away unshot at, all our barrels being empty. After I had loaded, yet an eighth bird got up a few yards ahead, having crept out, I imagine, while the dogs were at down charge, and I was fortunate enough to kill it also-thus bringing four Ruffed Grouse to bag, which were sprung one by one, or very nearly so, out of a thicket less than thirty feet in circumference. We ought certainly to have got one more bird, at least; and had we been as silent as we should, might possibly have bagged them all, for they all rose within four or five yards of our gun-muzzles, and the place was quite open and fair shooting ground.

I never saw a more evident proof of the great propriety, and great gain, of attending strictly to the most minute rules of sportsmanship and woodcraft; like laws of military tactics, they can never be violated with impunity; and though we observe them ninety-nine times, the violation on the hundredth will almost certainly prove disastrous.

I know an instance of a good sportsman in the city of NewYork, whose name I do not record, giving him the credit of a rernarkable feat; because, being in business, it might injure him among those gentry of the street, who think no hunting but dollar-hunting respectable! who actually brought to bag eight Pinnated Grouse, in succession, without limself moving from his ground, or his dog breaking its point. This occurred, some years since, on Martha's Vineyard; but, as I have observed before, I know no authentic instance of the Ruffed Grouse ever lying in the same manner, after the separation of the broods. Before that period, they of course lie to the dog as the Quail, the Prairie Hen, or the Grouse of the British Isles. Hence, I consider the day fixed by our legislature for the end of close time, as too late in regard to the Ruffed Grouse.

The constantly repeated tale, that the Ruffed Grouse when it alights in trees in companies, which it occasionally will do, in the spring, when eating the young buds, of which it is extremely 
fond, will allow the whole flock to be shot down, one by one, without stirring, provided the shooter takes the precaution of shooting that which sits the lowest on the tree, first, is as fabulous, as it is, on the face, ridiculous.

Mr. Audubon notes this fact, with his wonted accuracy; adding that during heavy snow storms he has sometimes killed three ur four. This is credible enough; starvation will make any bird or beast tame, and snow appears, while falling, to have a peculiar effect on birds of this order-unlike rain, which makes them wild-rendering them very unwilling to rise.Savages in this region of country-I can designate them by no other name-often shoot whole bevies of Quail while huddled together on the ground in their little circles, during snow sto $\mathrm{ms}$, in this manner, at a single shot. So far, however, are such foul practices from deserving to be recorded as modes of killing game, that I only speak of them here, in order to uphold them, and all who practice them, to the contempt and abhorrence of every one who would be termed a sportsman.

I have been told that these birds exist in such abundance on the Kaatskills, and in all that region of country, that it is well worth the while to go out in pursuit of them, without reference to, or rather with no chance of finding any other species of game. This I, at least, shall never attempt; nor shall I ever advise any person to do so. I know that they abounded in that district of Connecticut of which I have spoken above, as was proved by the fact that many scores were offered to me for purchase, which had been snared, yet it was impossible to get shots at them over dogs.

Again, throughout the semi-cultivated portions of all the Eastern States, and especially in Maine, the woods are literally full of them; yet such are their peculiarities of habit, that it is useless to attempt to have sport with them. A man, stealing along the old grassy wood roads, keeping absolute silence and a bright look out, may manage to pick up a brace or two in the course of a day, and this is probably more than the best sportsman living can effect with the best dogs, in that region of country; but that is not sport for sportsmen! 
The Ruffed Grouse is a singularly handsome bird, whether on the ground or on the wing; looking, from the looseness and downy habit of his feathers, considerably larger than he realiy is. He rises with a very loud whirring of his wings-which Mr. Audubon asserts so positively, that I must suppose so accurate an observer to be surely correct, to be uttered merely at moments of alarm and sudden trepidation, the bird when not forced to take wing, rising noiselessly-and gets under way with extreme rapidity. In general, this bird does not rise much higher than a man's head, and then flies very straight, and very swiftly, at an even elevation for several hundred yards; after which it will set both its wings, and sail dead before the wind with immense velocity. To kill the Ruffed Grouse, when thus skating down-wind, as it crosses you, having been flushed at a distance, it is necessary to allow a considerable space for the swiftness of its motion; and I should fire not less than two feet in front of one, at thirty-five or forty yards' distance.

Going directly away from the gun, the Ruffed Grouse, like the Quail, is an awkward bird to kill, from the fact, that they both fly with the body so nearly level, that the rump and hard bones of the back receive the shot; and in this part of the body they will have to be struck very heavily, before they will fall. It is a good plan in this position to shoot a little low, as you are far more apt to over than to under-shoot them.

A cross shot, if not too far off, is easily killed; as the bird affords a fair mark, and will not carry off nearly so much shot as the Quail, if struck well forward.

Beginners are apt to shoot behind all their cross shots, and perhaps especially so at this bird, his long tail and loose feathers tending to deceive them.

It is a matter of exceeding surprise to me, that this bird has not been naturalized in Great Britain. Its extreme hardihood would render its success certain ; and in every part of the country, but in the woodland and forest counties especially, Dorsetslire, Devonshire, parts of Essex, the New Forest, throughout Wales, and in many districts of the North Country, and Scot- 
land, it would very soon become abundant. Indeed, the hedge rows would be sufficient to hold it, everywhere; and from what I have seen, and stated above, of its habits in the low grounds here, I do not doubt that it would there afford sport equal to any English bird, except the Red Grouse. Its flesh is delicious, if dressed properly. It will bear to be kept hanging, in the autumn, two or three weeks with manifest advantage; it should be roasted quickly, before an extremely hot fire; and it should be exposed at once to the full heat, at a short distance, so as to sear the pores of the skin, and prevent the exudation of the juices; after a few minutes it may be withdrawn from the focus of heat, until it shall be cooked through. It should be eaten, as should the Grouse and Quail, with bread sauce and fried crumbs, - any sort of jelly, or sweet condiment, with any gallinaceous fowl, or any meat that is not immoderately fat and luscious, is an abomination. As a variety, either this bird, or the Quail, is delicious larded, boiled, and smothered in celery sauce; and the Quail, en passant be it said, is undeniable in a pie, with a fat rump steak at the bottom of the dish, a dozen hard-boiled eggs, and the slightest possible soupgon of garlic, and one cayenne pepper-pod.

If intended to be eaten cold, both birds are better boiled than roasted; as they will be found on trial much juicier, and less dry, than in the usual mode.

The plan resorted to by French cooks, who never know how to cook any sort of game, except in salmis, or the like, of blanketing these birds in pork fat, cut thin, before roasting them, is, of course, entirely wrong. It prevents the grand desideratum, namely, the searing of the skin, so as to make it contain the natural juices; and, instead of its own game gravy, saturates it with the essential oil of pig.

The epicure will prefer the back-bone and thighs of this delicious bird; and, by saving them for himself, he will also gain the credit of great disinterestedness from the ladies, and the snobs,-Heaven forbid that I should intend a comparison, in thus uniting them! but it is a fact that they both invariably 
prefer the bosom, as I believe it is the fashion of these modest days to term the white meat.

For the benefit of what the French are pleased to call amphitryons, the excellent men who are rich enough to gire good dinners, and of the happy men who are allowed to eat them, I will add, that red wine is the thing with game of all kinds. The right thing of all is Chambertin, or clos de Vougeot! but, in default of these, a sound Lafitte or Latour claret is excellently well in place. Champagne is not the thing in the least; and, for those who aspire to feed themselves or their friends creditably, without aiming at the expense of the costly French red wines, allow me to suggest, that a glass of good gold sherry is perfectly allowable with game. Except at a bali supper, no one, except counter-jumpers, ever think of champagne, beyond one tumbler with the roti.

'The next thing to killing your game handsomely, after finding it gnostically, is undoubtedly knowing how to set it on the table, for the benefit of your friends, in perfection, and with the proper accessories; and a hint or two on this subject may be pardoned, even in a work on field sports,-especially where such abominations are practiced, as eating Snipe and Woodcock high, drawing the trail, and broiling them; and eating currant, or plum jelly, with roast Grouse; or cranberries with venison.

Nothing in my eyes is more contemptible, than the man who cannot rough it upon occasion,-who cannot dine heartily, and with a relish, on a bit of cold salt pork, and a crust of bread, when he can get nothing better; but nothing is rnore stupidly, or hopelessly savage, than the man who does not care what he eats.

In the code of game-cookery, the gridiron is an article of the kitchen prohitited, unless in the case of a venison steak, a Bear chop, or a Wild Duck. To broil a Quail, or a Grouse, much more a Snipe, or a Woodcock, ought to be made-like frying a beefsteak-death without benefit of clergy. 


\section{GROUSE SHOOTING.}

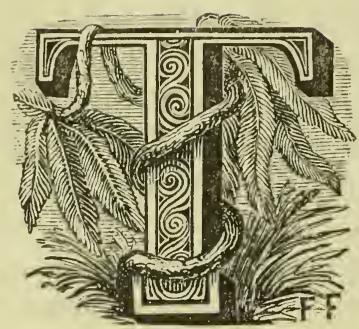

HIS noble sport I have never mysel. had an opportunity of enjoying, though I still live in the hope of finding myself on some fine autumnal morning, in the Western Prairies, with two or three brace of good dogs, a staunch companion, and all appurtenances suitable for a month's sport.

They are in all resperts the noblest bird, which is to be shot over Pointers in the United States; and the vast numbers in which they are still found in their own Prairie-land, the magnificent range of country which is spread out before the eye of the sportsman, the openness of the shooting, and the opportunity of observing all the motions of the dogs, must render this sport, like the Red Grouse shooting in Great Britain, the Queen of American field sports.

In the state of New Jersey a few packs of these fine birds still breed annually among the sandy pine barrens along the southern shore; the best of these shooting grounds are now exclusively occupied by three or four gentlemen resident in the vicinity of Burlington, Bordentown, and Trenton, who either rent or have purchased them for the purpose of sporting thereon, and on the pretence of wishing to preserve them. I say the pretence, for I grieve to say that no feeling of chivalrous sportsmanship deter these gentlemen, some of whom are excellent shots, from butchering these noble birds even in the month of July, when they are utterly unfit for killing; and for this outrage on sportsmanship and humanity, there is the less palliation-excuse or justification, there never can be any-in that occupying the grounds exclusively, they are safe from the apprehension of being anticipated by poachers or pot-hunters. Why, then, they should them- 


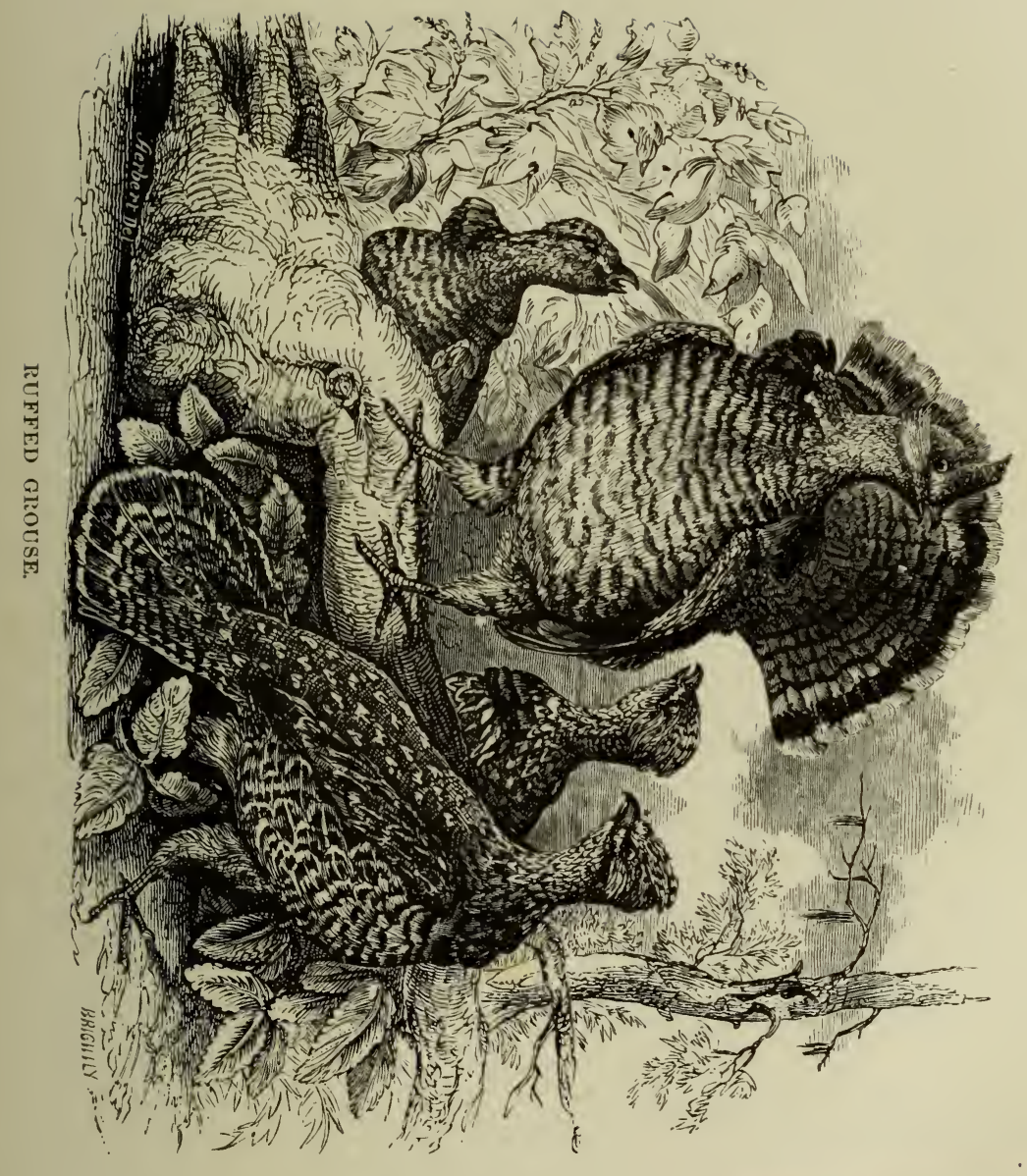



selves poach and pot-hunt, is absolutely inexplicable and inconceivable. I trust that this notice, from which I have purposely withheld the names of the offenders, in order to avoil personality, will deter them from the like criminality in future against the letter and spirit of the laws, which should rule all true sportsmen.

In Martha's Vineyard they are so strictly preserved, that $I$ have never taken the trouble of travelling thither on the chance of obtaining permission to shoot at them, although I am well aware that there are sportsmen from New York who resort thither yearly in pursuit of them.

On the barrens of Kentucky, where they formerly abounded, as in the Eastern States, they have become extinct ; and, in truth, unless the sportsman is prepared to travel so far as Chicago, St. Joseph's, or St. Louis, he has not much chance of obtaining anything to reward his pains, in the way of Grouse shooting; and it is, perhaps, worth observing, that in the present advanced state of internal communication with the Western Country, there is no real difficulty, and no great expense, in the way of the adventurer who would try his fortune on the Heath-Hen in its own wild haunts. The facilities of steamboat travel are particularly favorable to the transportation of dogs; and it would, doubtless, well repay a party to set off at any time after the first of September, with a strong kennel, for the prairies.

This Grouse breeds early, the nest being generally finished on the first of May; the eggs are rarely more than twelve in number, the hen sits eighteen or nineteen days, and the young run so soon as they are hatched. This species never raises a second brood, unless the first is destroyed. About the first of August the young are about equal in size to the Quail, and are, I regret to say, at that age, and a little older, butchered, and pronounced excellent eating by men who take the name of sportsmen.

A writer in the "Turf Register," under the title of "Tom Trigor," a fellow of infinite humor, and of so very correct opinions on a great variety of topics, that I marvel at his practice in regard to Grouse, discourses thus on the habits and modes of shonting this bird. as he understands them :- 
"Well then," says he, "these noble birds early in September, or even so soon as late in August, who have whooped, and strutted, and trumpeted the live-long spring and summer, the undisturbed possessors of the prairies, are now leading ahout their broods, some three-quarter parts grown, and they are at no time in better condition for broiling, the most delicate spring chickens yielding to them in flavor; and, at the same time, their behavior in the field is far more satisfactory, and accommodating, than at any other period of their lives. They now, when once they have scattered, stick to their concealment in the long grass, till you kick them up with your foot, and the amount you can then bag, need be limited only by your forbearance or your industry."

In my humble opinion, "Tom Trigor's" gastronomy and his sportsmanship are about on a par, both execrable. The man who would broil a Grouse at all, when he could possibly cook it otherwise, or who could compare it by way of praise with a spring chicken, must have about as much idea of the qualities of game on the table, as he who thinks they are in perfection for shooting, when they are too weak to rise on the wing. I should think their conduct would be more satisfactory yet, to such a gunner, before they could fly at all.

Seriously speaking, from all the really good sportsmen with whom I have spoken of Grouse shooting, I learn that the defect in the sport consists in the extraordinary tameness of the bird, and the infinite facility of knocking it down at the commencement of the season,-the killing, in fact, partaking almost the character of butchery.

To quote once more from the writer above cited:- Let the gnnstics preach about its being not 'sportsmanlike, and unhandsome, to knock down more birds than you can consume.' I'll make out, when I can, my twenty brace notwithstanding; and I have never seen Grouse yet at such a discount, at this season of the year, but what all that could be killed could be consumed; and, if I haply should a little overstock the market, there is no fear of thinning off the tribe, for their name is legion, and the 
farmers will not grieve when they reflect that there will be, at any rate, by so much the fewer depredators on their corn-fields next autumn and winter, when it may truly be said, they are fruges consumere nati. Moreover, we must make the most of them now, for in six weeks they will change their character and habits so entirely, that by no ingenuity can we possibly get near enough for a shot; and the devils, though they now tumb?e over on the reception of two or three No. 8 shot, will then carry off as much lead as a Galena steamboat. It is astonishing how difficult the full-grown birds are to kill,-I have known them, when riddled with No. 4 s'rot, to fly entirely out of sight and leave you bending forward your neck, in hopes that as you have knocked off feathers enough, as it would seem, to fill a bolster, that straight and rapid flight must soon falter; but no, on goes the bird in a 'bee line,' till his figure melts into thin air," \&c.

It is, indeed, sorry work, when a man who writes so very well, and who seems to possess very many of the genuine ideas and feelings of a sportsman, should condescend to promulgate such mischievous nonsense as the above. I note this the more willingly, because to such selfish sophistry, on the part of sportsmen, more than half the difficulty of preserving game is directly ascribable.

For who, if the sportsman shoots out of season, because it is easier to kill half-grown birds than full-grown ones, or because there are so many of them, that two or three score, or hundreds, more $01^{*}$ less, will not be missed, will abstain from doing likewise? Or how shall we, conscious of such a beam in our own eye, venture to extract the mote from our brother's ?

The arguments advanced-if arguments they can be calledin the above precious paper, are equally applicable to every other species of game that flies.

The Quail is a very hard bird to stop when full-grown, and well on the wing, especially in wild weather, and thick covertan infinitely harder bird, in proportion to its size, which makes it all the more difficult to hit, and precludes the pussibility of using large shot, than the Grouse-but I am happy to say, tha 
I never in my life heard a sportsman advocate shooting Quail in July, because it is easier to kill them then, than in November. Again, that it is not impossible to kill Grouse-Prairie Henin the autumn and winter, is rendered sufficiently evident by the quantity of these birds, killed with shot, which are exposed annually for sale in the New York and Philadelphia markets, over and above all those which are consumed in their native regions.

Lastly, the reasoning on the number of the birds, is precisely that which has led to their annihilation in the Eastern and Midland States, and even in Kentucky, and which is equally applicable to every species of game in every district whe re it is abundant.

I have heard the very same sort of talk held by countrymen, in defence of the vile practice of shooting Woodcock in spring, where there were then thousands of those birds. The consequence of that talk is, that there are now none in those regions.

The truth is, that until the middle of September, the young birds are not very strong on the wing,- after that period they become gradually wilder and stronger, and take longer flights, sometimes even to the distance of two or three miles in open country.

Their flight is less rapid than that of the Ruffed Grouse, though of the same character. It does not make so loud a whirring as it first rises, but once on the wing, uses the same straight even course, maintained for some distance by frequent beats of the wings, after which it will float for several hundred yards at a time on balanced pinions, with the velocity gathered from its previous course. It is said very rarely to pass over the person who flushes it, even by the most sudden surprise.

It feeds on stubbles and in maize-fields, and is to be hunted for in the vicinity of such grounds, where it will be found in the greatest abundance. On open prairie-grounds, the highest and speediest rangers are, of course, the best dogs over which to shoot the Grouse, as is the case with the Scottish red game, provided always that the animal has good nose enough to stand them at a long distance, and is staunch enough to allow the sportsman to come up from a distance, without moving on, or flushing his birds. 
I should presume that, for Grouse shooting in general, the Pointer would be preferable to the Setter, as this bird is notorious for its dislike to watery or marshy ground,- and it is the Pointer's preëminent merit that he can endure more hours of thirst, than any other of the dog kind. The Setter, on the contrary, very speedily loses his power of scenting, and soon afterwards his whole energy and strength, in hot weather, where water is not to be obtained. For this reason, to the Eastward, in New Jersey, and Pennsylvania, in all of which, brush plains, pines, and oak barrens, the soil is equally dry and sterile, the Pointer is as much preferred, as he is in the similarly dry Partridge shooting of England. The British moors, on which the Red and Black Grouse are found, abound with springs, wellheads, brooks, and morasses, and on these the greater speed, daring, and dash of the Setter, as well as the advantage he derives from his well-protected hairy feet, gives him the call decidedly over his smooth-haired rival.

Mr. Audubon observes on this point, "In the western country they rarely stand before the Pointer; and I think the Setter a more profitable dog there ;" but I must confess myself entirely at a loss to comprehend the meaning oi this passage.

In Europe, it is very true that the Setter naturally crouches close to the ground, falling flat on his belly when he comes on the scent of his game even at full speed, and flattening himself the nearer to the earth, the nearer he is to his game, while the Pointer invariably stands erect to point his game.

If this distinction held good in this country, the meaning of the above passage would be clear, but such is not the case. There is no difference whatsoever, of which I am aware, in the style of Pointers and Setters finding and pointing their game on this side the Atlantic. I have always shot over Setters, preferring them, by all odds, for general work, and have owned at least a dozen good ones myself since I have been in the country, hesides shooting over scores belonging to other persons, and I never in a single instance have seen a Setter set a bird in America. This is not a distinction of training but of natural 
habit in the races; and it is worthy of remark that the best dog 1 ever owned here was one which I imported from England when a small pup, and had broke in New Jersey. I never saw either his dam or his sire, over both which I shot in England, point a bird, and I never saw him set one. The first bird he ever scented was a Woodcock, on the fourth of July, and that he stood, with head and stern high in the air, as showily as I ever saw a Pointer stand.

Nothing has ever puzzled me more completely as regards field sports than this fact, and I cannot figure to myself any reason that is at all satisfactory for the difference of habit, in the two countries. I have sometimes fancied that it might arise from soil or climate rendering the scent colder here than in England-for it is certain that the hotter the scent, the closer the dog sets-but I cannot see that this holds good by analogy, as I think dogs find and point their game fully as far off here as in Europe.

This observation of Mr. Audubon's has brought the matter, at this moment strongly to my mind, and has almost raised a doubt within me, whether to the Westward the Setter may not possibly resume his natural inclination to set rather than stand his game.

In wooded regions it is to be remarked, that these birds are rarely if ever to be found among open groves and tall timber, such as are peculiarly loved by the Ruffed Grouse; they frequent tracts of low bushes and stunted underwood; and when on the wing will fly for miles rather than alight until they can find a clear place, such as an old road-way, or a new cutting, in which to settle. They generally run forward swiftly as soon as they strike the ground, and not unfrequently press themselves into thick covert, where they squat, and are compelled to lie hard by the difficulty which they experience in taking wing, from the opposition of the dense foliage.

They are a shy bird in covert; and are of course much wilder to the Eastward, where they are incessantly persecuted, than in the Western Country. 
The Grouse invariably makes a clucking noise when it takes wing before a dog, and if it rises within distance, is a very easy shot. No. 8 early in the season, and later No. 5, are the best sizes of shot. After that, I should prefer red Ely's cartridges, of No. 5 shot, which I will be bound to say will fetch them from a good twelve or fourteen guage gun of proper weiglit, held by a quick hand, and levelled by a true eye, at any perior of the season.

Mr. Audubon observes, contrary to the remarks cited above from W.lson and Dr. Mitchill, that the Grouse drinks when in a state of nature, like the common fowl, and farther, that it is exceedingly susceptible of domestication, even breeding freely in captivity.

The remarks with regard to beating with dogs for the Quail and Ruffed Grouse, and for shooting both these birds on the wing, except so far as they are here modified, are all applicable to the Prairie or Heath-Hen.

The flesh of this bird is not white, like that of the Ruffed Grouse, but red, like that of the Scottish Moor Fowl, which in many respects it resembles. It has more of the bitter taste than the Ruffed Grouse, and is, in my opinion, a decidedly superior bird. It will bear to be hung for some days, or even weeks in cold weather, and is to be cooked and eaten according to the direction given under the last head.

In conclusion, it is well to state here, that there is certainly no distinction whatsoever between the Heath-Hen of Long Island and Martha's Vineyard, the Grouse of the pines and scrub oaks of New Jersey and Pennsylvania, and the PrairieHen of the West.

They are all one and the same hird-the Pinnated Grouse, Tetrao Cupido, of the ornithologist, and emphatically THE Grouse of the sportsman.

Of the Canada, or Spotted Grouse, it is in vain to speak, for he is not as yet to be shot, and I apprehend never will be, in sporting style. The ground in which to find him is the deep larch and cedar woods, especially the former, of Maine, Nova vol. I. 
Scotia and New Brunswick, and if anywhere he exists in sufficient numbers to render the pursuit of him exciting as a sport, I have no doubt that the dogs over which to shoot him would be well broke Cocking Spaniels.

I believe that the flesh of this species is the most highly flavored of all the varieties of Grouse which we possess, though I but once had an opportunity of tasting it. It is said to be very bitter, which I presume to be that spicy, aromatic game flavor which gives the zest to the Grouse above all other birds, in the eyes of the true epicure.

Thus far, with some few exceptions, I had written in my first edition of this work-these exceptions are the correction of two or three positive and palpable errors in relation to the growth, size, and seasons of this admirable bird. I am still myself of opinion, that in the main the spirit and letter of what is above set down will be found correct; but having had the good fortune to receive a very interesting original communication from a gentleman of distinction and zealous sportsmanship in the South-West, I hasten, with sincere acknowledgments of his kindness, to insert his letter entire, certain that it will be read by all sportsmen with pleasure and profit, and that its statements and opinions may be received with perfect reliance on their correctness and fidelity.

I have only to add that the handsome present of game, to which reference is made below, arrived in perfect condition, and were dealt with in perfect accordance with the desire of the obliging donor. I cannot, however, coincide with his views, as I still think-though I admit that a broiled Grouse is good enough - that it is much inferior to one roasted before a very brisk coal or wood fire-I do not mean baked in an oven, which is very often called roasting-and served, slightly underdone, with bread sauce. All jelly or sweet sauce with Grouse are an abomination.

I have not yet had the good fortune of being able to comply with my friend's kind invitation to participate individually in the noble sport of the prairies, though I earnestly hope to do so ere many autumns have elapsed; nor had I the pleasure to see his 
friend, Mr. M., although I should have rejoiced to see and confer with him on the subject of the sports of the South-IVest, of which I have seen too little, while I desire so greatly personally to participate in them. I may also add that I have learned from good sportsmen of the West, that the objection against the use of pointers, lies in the inability of their thin-skinned legs and baresoled feet to endure the wear and tear of the prairie grass.

\section{St. Louis, Mo., January 29th, 1849.}

SrR :-Not only are an author's works the property of the public, but his readers beconie in some degree his acquaintances. $\mathrm{He}$ addresses his readers familiarly, sometimes almost affectionately, especially when, as in your case, the subject is such as to establish a kind of free-masonry between him and all true lovers of the dog and gun.

Having read both your original works and your translations, I feel as if I had some right to address you without the formality of an introduction. I wish to thank you for the additions you have made to our knowledgé in sporting matters, and to say how heartily $I$, in common with all who wish to perpetuate the manly and healthful sports of the field, concur with you in opinion of the desirableness of some measure of legislation which may arrest the rapid destruction of the noble birds which yet adorn our prairies and forests, and which will render it penal-it ought to be infamous-to kill game either in the breeding season or before the young birds have acquired full strength of wing.

I have been particularly struck with the article on Grouse shooting, in vol. 1, and seq., p. 248, of your "Field Sports." With the principles which actuate you I entirely concur. But, as I conceive, you are slightly inaccurate in several particulars of the natural history of the Pinnated Grouse : and this has led you into error-as I think-in fixing the time-middle of October-when Grouse shooting ought to begin.

Secondly, I think you are gastronomically wrong when you speak of the oniy mode in which the Grouse, when legitimately killed, should be cooked for the rational epicure. In my opinion 
you have not indicated the best mode of preparing him for the table; of which nore will be said presently. I will state the reasons for my dissent from your views; and you must bear with me if I am tedious.

You say, vol. 1, p. 249, "About the first of August the young are about equal in size to the Quail," \&c.

I speak for the West only in what follows. There may be a difference in the habits of the birds here and in the Atlantic States; I am inclined to think there is. I am of opinion that the months of April and May are warmer, and September and October are colder in Missouri and Illinois than in Maryland. My professional engagements-I am a lawyer-prevent my giving to the habits of the Grouse the study to which my tastes incline me. I cannot say, with accuracy, at what time their nests are finished, or their broods hatched. But the young birds are much larger than Quail on the first of July; and in this condition, scarcely able to flutter out of the grass, they are, to the disgrace of all participants in or encouragers of the atrocity, killed in great numbers, sold dearly, and eaten greedily. At this time the flesh is white, tender, and tasteless.

I do not desire you to hold your hand from smiting " Tom Trigor," and all who are like unto him, according to their deserts. But if he speaks of the Grouse in the States of Illinois and Missouri, he is as far wrong in his attempts to give their natural history as he is wanting in every feeling of the sportsman, in the article which you quote from him. My own experience is opposed to everything he says on the subject of Grouse shooting, as it exists in this neighborhood. I have shot Grouse in the first week of August,- - this was before I knew better, and I will never do it again,-in the middle of that month, at the close of it, in all of September, in October, and November. I condemn, as decidedly as any one, the shooting of any bird of game before it is strong on the wing. I consider the first of August too early for Grouse shooting, yet I can assure you there is good sport by the middle of that month. The birds are of full size, full fledged, 
strong on the wing, and hereabouts, at least, wild enough at times during that month to task the best gun that ever was fired. 'The sport is best, however, in September and October. During these montbs the killing heat of the summer weather, which sometimes proves fatal to men, and frequently to dogs and horses on the prairie, is moderated; the birds aequire an inerease of strength, but not of size, and get under way in a shorter time after rising than during the summer. They do not lie so well before the dog, but the seent of the Grouse seems so strong, that most pointers stand at the distanee of from ten to twenty yards from them, unless in very warm weather: and it is certainly mueh more satisfaetory to bag a wild, wary bird than to seeure a tame victim. After the cold weather we sometimes have on the prairies early in September, the Grouse will sometimes rise for days together entirely out of range. But in those days, either of September or Oetober, when the morning is ehill and frosty, and the middle of the day calm and warm, the best Grouse shooting of the whole year may be had. If they are driven from the corn and stubble fields at this time, just as they have completed their morning feed, marked down in the open prairie, and let alone for an hour or two, the sport is really magnifieent. It is not uneommon at sueh times, to find them scattered over a spaee ranging from 20 to 60 aeres. Not more than two or three will be found so near together as to be flushed at the same time, and very often they are pointed singly. They rise, to be sure, with a strong pinion, and get under way in an instant, but still they cannot be termed hard to kill, I think. I never shoot smaller shot at Grouse than No. 6, and after the tenth of September I shuot No. 5. When No. 8 or No. 7 will stop them, they are too young to be shot at all. The instanees are comparatively few of their flying off with their death wound, whereas nothing is more common than for the Quail to do this. There is little oecasion for shooting the birds at a greater distance than forty yards, and the bulk of the shots are at birds within thirty yards, during the month of September. In October it is sometimes otherwise, but 
the wildness of the bird at this time is greatly exaggerated. If men will go into the fields, rating their dogs loudly, and talking and laughing with each other, the birds will be wild of course. But throughout the three fall months, except on some few days, the Grouse are not too wild to be hunted with the dog in suitable weather.

There are some exceptions, however, and I have even known them to occur in August. After the 15th of that month it is difficult to distinguish the young birds from the old by their weight, or even their plumage; and it certainly is almost impossible to distinguish any but the most backward broods on the wing. The difference between the general size of the birds and that of a backward brood is very appreciable. It is a difference, not of one or two weeks, but of more than a month. No sportsman is excusable whc does not spare such a feeble prey. I was in the field on the 14th and 15th of last August, about 30 miles from St. Louis; and on the evenings of both days, and the morning of one of them, we were disappointed of our expected sport by reason of the wildness of the birds, although the weather was warm and cloudy. None of the birds we killed were too young-that is, we killed none which, either flying, or lying at our feet, or in our hands, could be distinguished from the old birds without a reference to marks, which would be as obvious in September or October as they then were. We used No. 5 shot, and made many shots outside of forty yards.

The number of these birds brought to St. Louis and consumed annually is almost incredible. From the month of October to the end of February thousands are brought to St. Louis every week. Many find their way to New Orleans, Louisville, and Cincinnati. At the present rate of destruction they cannot last long; and such is the antipathy to laws for the preserving of game, that I almost despair of any legislation in their favor. There is one ground of hope, and that is not very assured. It arises from the importance of this bird to the farmer. Within late years the numbers and depredations of grasshoppers in the 
prairie farms have greatly increased. It is necessary to see the clouds of this insect which sometimes infest our fields, to realize the stories that are told us of the ravages of the locust in other lands. Now the increase of the numbers of the grasshopper has been found to keep pace with the destruction of the Prairie Hen or Grouse; and, it inay be, that some step may be taken by the Legislature of Illinois, prolibiting the killing of these birds by a law which would equally benefit the farmer and tend to preserve one of our noblest game birds.

In July, the flesh of the Grouse is white, tender, and insipid. When the bird has attained his full size, his flesh is dark all over the body. I have heard some persons--of the class you mention as preferring the breast to the thighs and back bone of the rufffed Grouse-insist that the bird was better when in its half-grown state than at any later period. I am decidedly of opinion, that until the Grouse arrives at its full size, its flavor is not perfect, and that the bird is finer and fatter, communibus annis, in January, than any other month. I have been told by two of the best and keenest sportsmen of my acquaintance, that in the prairies remote not only from the cities, but farms, where the chief food of the Grouse consists of grasshoppers, prairie grass and grass seeds, the flesh has a peculiar and very fine flavor. This may be so, but I have never had any opportunity of testing it.

I now proceed to my second point. I am unalterably of opinion that you are wrong about the mode of conking the Grouse. I have fairly tried all your recipes, with a wish to be convinced of their excellence, and I am free to say that roast Grouse with bread sauce is not unsavory. But it hides its diminished head before Grouse properly broiled, served up very hot, and eaten from hot plates. I fear you are rather bigoted on this subject. Much theorising has hardened your heart. With the purpose of inducing you to review your-hasty-opinions on this vital point, and correct the errors of speculation by the lessons of experimental philosophy, I take the liberty of sending you six brace of Grouse, the freshest and finest I could select on this occasion. I 
have caused them to be packed in a basket, which is the bost means I am aware of-except hanging them outside of the vehicle which carries them, and that is unsafe-of preserving them from becoming $h i g h$. I hope they will reach you safely and in good order. Have one of these birds broiled quickly, rather underdone, as a canvass-back duck should be roasted; let it be peppered and salted to your taste, and as it is removed from the gridiron to the hot dish, let it be just tcuched with a little butter. Eschew all sweet sauces-jelly, \&c., and eat it with nothing but good bread, 48 hours out of the oven. Should this experiment not please you, try another one of the birds on the gridiron; but if that too is a failure in your estimation, e'en have the rest cooked selon votre-mauvais?-gout.

I conclude this very long letter with the expression of a hope that you will be induced to try for yourself what Grouse shooting on our prairies is good for. The journey is nothing. Any one who has the time can enjoy it pleasantly here if he is fond of field sports. St. Louis is the best headquarters for a sportsman in the whole country, I verily believe. You will find here a cordial welcome, and I should be very much pleased to receive you as my guest. My professional engagements are so confining that I can but seldom enjoy the pleasure of shooting; for our courts are in constant session during the whole of the hunting season, after the $3 \mathrm{~d}$ Monday of September; but before that time I am comparatively at liberty, and there are others here, of greater leisure to indulge in field sports, but not more keen in their pursuit, who will rejoice to contribute to render pleasant the visit to the West of a sportsman whom every other one in America knows by reputation at least.

$$
\begin{aligned}
& \text { I am, sir, very respectfully, } \\
& \text { Your obedient servant, } \\
& \text { T. T. } \mathrm{G}^{* * * *} \text {. }
\end{aligned}
$$

Henry William Herbert, Esq., at the Cedars, New Jersey. 


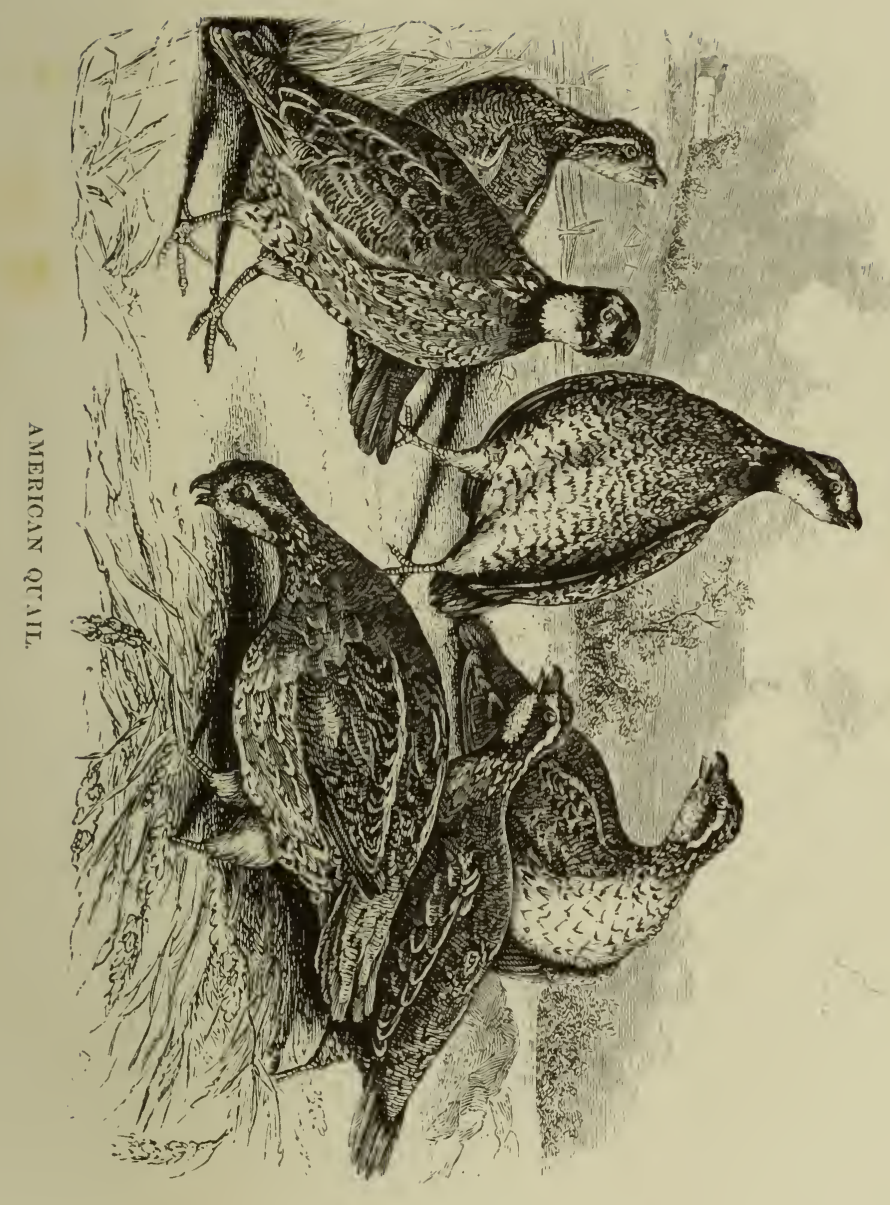





\section{A UTUMN SHOOTING.}

IT is brilliant Autumn time, the most brilliant time of all,

When the gorgeous woods are gleaming ere the leaves begin to fall;

When the inaple boughs are crimson, and the hickory shines like gold,

When the noons are sultry hot, and the nights are frosty cold;

When the country has no green but the sivord-grass by the rill,

And the willows in the valley, and the pine upon the hill;

When the pippin leaves the bough, and the sumach's fruit is red,

And the Quail is piping loud from the buckwheat where he fed ;

When the sky is blue as steel, and the river clear as glass,

When the mist is on the mountain, and the netivork on the grass;

When the harvests all are housed and the furmer's work is done,

And the ivoodland is resounding with the spaniels and the gun;

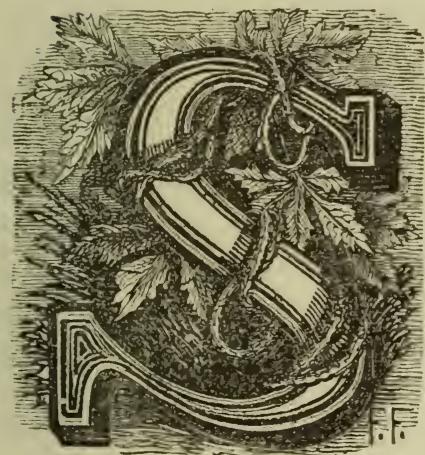

$\mathrm{UCH}$ is the season of the sportsman's adoration; to him, the lover of boon nature in her loveliest mood, these days are not, as Mr. Bryant in his beautiful poem has described them, to him at least, "the melancholy days," "the saddest of the year," nor, with all deference to that sweet bard and moralist of the woods and waters, ('an I agree with him as to the tone of sentiment and feeling excited by the contemplation of the scenery of an American autumn.

It is true that we know ourselves to be looking upon, as it were, a hectic loveliness, which, like the glow on the cheek of consumptive beauty, is the precursor of decay and death. Still, so exquisite is that beauty, so delicious the temperature, the atmosphere, the aspect of the skies; so gorgeous the hues of forest-mantled mountain and deep woodland, that to me the 
promise of spring and the fullness of summer are both inferior to the serene and calm decline of the woodland year. It leads to death indeed; but it seems to me rather to resemble the tranquil and gentle close of a well-spent life, beautified by the consciousness of good deeds done during the heat of youth, and in the heyday of manhood, and enriched by the hope of glor:es to shine forth after the winter of the grave, than the termination of an existence to be dreaded or deplored.

Every land has its own season of peculiar loveliness; and if the sweet spring-tide of soft and dewy England, with its May smiles and its April tears and its rich breath of flowery fragrance, has awakened the fond sympathies of her landscapeloving poets, the many-colored, purple-hazed, and silvery-skied autumn of America has neither been unhonored nor unsung of lyres worthy to hang aloft in high niches of the temple consecrate to the noblest tongue of the modern universe.

The true sportsman must ever be a lover of the charms of rural scenery, and for this among other things $I$ love and honor sportsmanship. I do not believe that any genuine forester, be his exterior as rough as the shell of the prickly chestnut, but must have within his heart, though he may lack words to define the sentiment, something of the painter's spirit, and the poet's fire. The very nature of his pursuits must needs awaken contemplation and induce thought, and I have often observed that the spots to which he will conduct you, apparently without a thought, except in reference to their convenience, wherein to take your noonday meal, or your afternoon siesta, will be the very places to charm the poet's fancy, or fix the painter's eye.

I think no lover of nature can be an unkindly, or, at the bottom, an evil-minded or bad man.

And so-and so? Instead of pausing longer thus, or solidly and solemnly discussing the theory of sporting matters, we will at once walk into the practice.

We will suppose the time of the year such as our poor balladmonger above quoted has, perhaps, labored to depict,- - the time 
of the morning, rot the peep of day, but eight, or by'r lady ! nine of the Shrewsbury clock, when the autumnal sun has lifted his broad, jovial, ruddy face, from his dewy pillow, and raised it, looming large and blood-red through the thin haze, above the mountain's brow. There has been a touch of frost during the night, and its silver fretwork is still white over the deep after-grass, and yet unaltered fern leaves. The air is clear and brisk, yet balmy, and its every breath seems to exhilarate the mind, as if it were champagne inspited by the nostrils.

The scene is a broad and gentle valley, bordered on either side by hills, cultivated to their mid height, and crowned aloft with the unshorn primeval woodlands. The meadows in the bottom, along the clear brimful stream-in Europe it would aspire to be called a river-are green and soft as velvet; but the woods and swamps in the vale, are rich with every color that the painter's pallet can afford; the blood-red fuliage of the maples, the gold of the hickories, the chrome yellow of the poplars, the red russet of the oaks, the dull purple of the dogwoods, mixed with the sable green of the late alder tops, the everlasting verdure of the rhododendrons, and the lightsome greenery of the willow, forming a marvellous succession of contrasts and accidents of light and shade, all blended into one harmonious whole, such as no other scene or season, no other clime or country, can exhibit.

And at this time of year, at this hour of the morning, and into such a landscape, we will imagine a brace of sportsmen emerging from the doorway of the country tavern in which they have spent the niglit, with their canine companions, and a stout rustic follower, loaded with supernumerary shot-belts and gamebags, carrying in his dexter claw a stiff hickory cleaningr-rod, and leading with his sinister a leash of large, bony, red-andwhite Cocking Spaniels.

Our sportsmen, for the nonce, adopting old Izaac Walton's quaint nomenclature, which figureth forth something of the character from the name, we will call Agilis and Peritus. The former youthful, and somewhat rash, yet neither altogether ver- 
dant nor mexpert in the mysteries of the fowlingpiece,- the latter deliberate, though ardent, perfect with the gun, steady with the dogs, and a master of those noble sciences, hight, venerie, and woodcraft.

They are both aptly habited for the field, in russet shootingjackets, of stout corduroy, or fustian, long-waisted waistcoats, low-crowned hats, and ankle-bnots of cowlide. The younger man, however, sports a pair of loose, fashionably-cut trousers, while the elder has donned knee breeches, and tight russet leathern leggins. Each lias a double-barrelled gun under his arm, and the other appliances of flask and pouch, hidden in his roomy pockets. Neither wears any game-bag, but an ivory whistle is suspended from the upper button-hole of both jackets,

The dogs which are following, docile at the heel, are a brace of Setters of the highest breed, one a red dog, with a black nose, and without a speck of white, except a snip on his breast, and a tag to his fine, feathery stern,the perfection each, this of the Irish, that of the English strain, and indicating in some sort that perfection by their colors.

"And so, Peritus," said the younger and slighter man, as they took their way through the outskirts of the village, "you augur well of our chance of sport to-day ?"

"I do not think, Agilis," replied his friend, "that there is any chance about it. It has been a good breeding year for Quail, and they say that they are abundant; then the autumn has been seasonable, and the nights have not been sharp enough to banish the Woodcock. There is a bit of pretty Snipe ground on our beat too, and we shall get a few couple, without doubt. Those, with a brace or two of Ruffed Grouse, which, I dare say, we shall manage to pick up among the cedar knolls, and along the wood-edges, a few Hares, and, perhaps, some Wood-duck, or Teal, or even a Mallard, by chance, will make up something in the way of a bag."

"Do you expect to find all these varieties of game? I have never shot above three kinds in a day."

"Ah! you have not shot before in autumn in America. For 
this very reason it is the prettiest and most exciting sport in the world; that you can never even form a conjecture what is going to get up before you, until you see it on the wing. Now, my good friend Rusticus, will you take yourself and the Spaniels to the tall oak tree on the brow of the hill yonder, and do your best to mark down every bevy we flush, to a yard. When we rejoin you, we will couple up the Setters, and beat the swales and thickets with the little dogs. Now, hold up, lads! look sharp, Agilis, they are drawing already. There has been a bevy running here since the sun was up. See how gingerly they crawl over the tainted grass. Now they are standing both of them. Is not that a picture?"

And they stepped up to the dogs, which held their point as stiff and staunch as if they had been cast in bronze, or carved in marble.

"Hold! Agilis! Don't head them, my dear fellow. I want to let them go, if they will, into those sprouts on the hill side. They are close under the red dog's nose. There! they are up! Steady!"

Bang! bang!

"Bravo! a brace, Agilis! very neatly done, I assure you ; you let them go far enough then, yet not too far, before firing. You never killed a Quail before, hey ?"

"Never on this side the water, Peritus. In France and Spain I have shot a good many."

"A different bird altogether, though of the same order. Not half so bold, or strong, or swift on the wing, as this, which some writers call the American Partridge."

"Is it a Partridge or a Quail, Peritus, after all ?"

"Neither one nor the other, Agilis, an intermediate link between the two, but approximating nearer to the Quail. See, the red dog has retrieved one-good dog, Sancho! A pretty bird, is it not?"

"Very. But what did you do? I was busy trying to mark the bevy, and did not see your shots."

"Oh! I killed two, of course. It was quite op?n. Did you nark them?" 
" No. I could not, with certainty. But I think they dropped in that bog-meadow, near yon pine tree."

"No, Agilis, you did not cast your eye forward sufficiently in watching them, as they skimmed low over the ground before the wind. They went four hundred yards farther, and are down in that thicket, with the willows at this end."

"Aye! you have a keen eye, Peritus. Well, let us follow them at once."

"Practice is more than keenness of sight, in marking. But we will by no means follow them at once. We must find several other bevies, and drive them, if possible, the same way."

"Must we,-that seems strange."

"Yes. I will tell you about it at luncheon time; but now come on. The dogs are roading another bevy. Look forward beyond the crag there, by the cedars."

But Peritus was in error; it was not another bevy, but a Ruffed Grouse, which rose a moment afterward with a loud whirring, out of a brake, and was cut down handsomely by the older sportsman, after being missed by Agilis ; who, fluttered by the noise, shot a little too quickly at him.

Five minutes afterward the black Setter stood suddenly and dead, in a dry maize-stubble, before Agilis, and a moment later Sancho drew, and came to a doubtful point in an opposite direction, without seeing his companion.

"Look alive, Agilis; that is either a Cock or a Hare before you, and Sancho is upon a running bevy."

It was, sure enough, a Hare; which bounced up instantly out of its form, among some long grass and weeds in the maizestubble, and was tumbled over before it had run many yards, by Agilis. At the report the bevy of Quail rose wild, and at a long distance ; which did not, however, hinder Peritus from dropping one, killed clean at fifty yards, or upward.

"A long shot, and a good one !" said Agilis.

"It was an Eley's cartridge. Loose shot would scarce have stopped him. Those birds have gone into the saplings on the hill-side, and they, I doubt not, are full of Woodcock. We are sure of sport now." 
"Shall we go after this bevy ?"

"Not yet, I had rather wait till they begin to run, we may very likely miss them otherwise."

On they went, therefore, and perfectly right were they to go, on ; for Peritus' mode of beating for Quail is the true one. This cunning little bird, having either the power, or the peculiarity, of retaining its scent for some short time after alighting, when it is alarmed, so that the best dogs in the world shall fail to find it. This may be an accidental provision of nature, possibly owing to some contraction of the pores, and consequent check of the odoriferous effluvium, owing to alarm; but I am rather inclined to believe that it is an absolute power of the bird, and arising from an exertion of will, - since I have invariably observed, during the period in which the Quail gives forth no scent, it cannot be forced to rise even in the openest and most easy ground, unless actually almost trodden on.

I have repeatedly marked Quail, literally to a yard, both in open bog-meadows, and in woods of tall timber, clear of underbrush, and have beat unsuccessfully with good dogs, immediately after marking them, until almost convinced that I was mistaken in the fact of their having dropped where I imagined. Yet, on returning afterward, when they had begun to move about, and call a little, I have found my first opinion to be correct.

On one occasion, I distinctly remember marking three Quail into a little briar patch, on a dry tussocky meadow, and seven more of the same bevy some fifty or sixty yards farther, into long grass and rushes, by the margin of a boggy stream, under willows.

At this time I was perfectly aware of the peculiarity of which I am speaking; but, owing to the lay of the ground, and the direction of my beat, I had no option but to try it at once. I beat the briar patch, which could not have exceeded twenty yards in diameter, carefully to and fro, with a brace of Setters, crossing and recrossing it, and myself kicking and trampling the bushes. but in vain. 
On coming under the wi!lows, both dogs stood instantaneous Iy on two different birds, which proved, however, to be Wood. cock. Eight or nine of these latter birds we flushed and bagged, without moving any Quail except one which I almost trod upon, a second a'ter my best dog had gone within a foot of it, taking no notice of its presence. My companions laughed at me, for expressing an opinion that the Quail were still there, within a few yards of us; but it proved that I was not in error.

A Woodcock went away unshot at, or at least unwounded, and led us a long stretch off the direction of our intended beat; while hunting for it we found another bevy of Quail scattered, and had some sport with it, by which we were amused and occupied during half an hour. Returning across the first ground, we got six points at six single birds, Quail, under the willows; and in consequence went back into the briar patch, scarcely entering it before the Setters stood on the first three.

The fact is difficult to explain, but a fact it is; and it occurs only with the unwounded birds. I have never known Setters to have the smallest difficulty in footing crippled Quail, which always run or tumble about as soon as they alight, or in pointing dead Quail. I have even seen dogs find one dead Quail among a whole bevy of live ones, which they could not scent at that time, but which they did subsequently hunt up in good style.

Therefore, I say Peritus was in the right of it, in drawing his distinction as he did on that day; for he not only improved his chance of finding more bevies by pursuing them while they were on the run in the early morning, and so scattering them into good shooting covert, where he was sure to find them again during the basking hours, when, unless flushed and marked down before, they can scarcely be raised, but increased the likelihood of finding his birds in good style. And all this he explained, in many more words than I have space to use, and with many an apt illustration, while he and Agilis were lying down under a sunny bank by a clear springhead, regaling themselves an hour or two after noon, with the cold chicken and 
the sherry which Peritus had recommended as the best form of luncheon.

"I have no doubt you are perfectly right about this, Peritus," said his friend. "Indeed, the practice has proved the principle, for we have got forty-five or forty-six Quail between us, out of those first four bevies, besides thirty Cock. It is glorious sport, indeed."

"Not very bad, certainly, Agilis; and you have shot well tno, which inclines you to think of the sport, perhaps, with more than ordinary complacency. But mark me, if we had followed up that first bevy we should not have flushed or marked the other five, all of which, you remember, the dogs trailed as they were rambling about on the feed, before the day got warm. It would have occupied us till eleven o'clock to pick up that one bevy, had we been able to move it, which is doubtful; and by that time all the others would have huddled themselves away into some little dry sunny nook or o:her, where it would have been ten to one against our stumbling upon them. As it is, before that same hour we had stirred six bevies, four of which we have used up, while I hear the other two calling even now in that great swamp, where we will give a good account of them likewise, when we have finished these cigars.

"Aye! I observe all this, and see the sportsmanship of it, Peritus; what noble birds, moreover, these autumn Woodcock are. All full grown birds, with fine gray foreheads, and pink legs. They must weigh one-third more each than the younglings we slaughtered in July."

"True, O king! at least one-third more. Now, don't you think we ought to give up summer Cock shooting?"

"I never thought otherwise. What between the thermometer at ninety in the shade, and the myriads of mosquitoes, I do not look upon summer shooting as fit sport for any man who is not as thick-shelled as a lobster, and him it would be likely to boil."

"What autumn shooting we should have, if they would but abolish summer Cock shooting, and enforce their own laws !" 
"Aye! indeed, but let us on. My cigar is finished. Hush! hush! What are those?"

"Wood-duck, by Jupiter! eight of them; and they have dropped in the bed of the brook, just under the big white oak tree ; they are after the acorns. Keep the dogs close, good Rusticus; now, Agilis, cram down an Ely's cartridge in each barrel and let us steal down upon them. Try to get a sitting shot on the water first, and then give them the second barrel as they rise."

"Excellent! excellent, Peritus. I see your words are about to be made good. I have bagged a Mallard already, and you two green-winged Teal-"

"And a Pin-tail," answered Peritus, " besides Grouse, Quail, Hare and Woodcock. And now we will have four or five Wood-duck; and there are the Snipe bogs. Off with you, but keep your head down and crawl low; the Wood-duck is not, however, a wild Duck."

Within ten minutes four barrels sent forth their contents, and five Ducks came to bag, and thence the friends went forward to the Snipe ground, where some eighteen or twenty long bills were picked up, fat, large and lazy; and thence again into the wide deep swampy woodlands, where the yelping of the Spaniels, the flip-flap of the rising Woodcock, the whirr of the startled Quail, and the louder hurtling of the Ruffed Grouse, succeeded rapidly by the loud ringing gunshots, gave note of glorious sport until sundown, when the increasing darkness put a stop to the joyous labors of the unwearied sportsmen. The tale of that day's bag, and it was a real day, and a real bag, was as follows :

Seven Ruffed Grouse, sixty-two Quail, forty Cock, nineteen Snipe, nine Hares, five Wood-duck, two green-winged Teal, a Mallard, and a Pin-tail, brought to bag by two guns, in about eight hours' shooting-one hundred and sixty-six head of game, of nine different varieties.

That is the best day's sport I ever saw; I fear I never shall see such another, certainly I shall not in the same region.

Nothing in the way of sport can, I think, be better, and such 
was twelve years since within fifty miles off New-York, such is in the interior of the southern tier of counties of that State, and such is in hundreds and hundreds of places in the West, the autumn shooting of America.

And that, mine English readers, without a game-keeper or a preserve in all the length and breadth of the land; and, I might almost say without a game-law,* so limited is the sphere of operation of these latter, so narrow and perverse their enactments, and-above all-so little are they regarded. But this alas! will soon, if not amended, abolish altogether the Field Sports of America.

P.S. The above note, when published, was subsequently discovered to be premature, and, as concerns Rockland County, is still unfortunately incorrect. With regard to Orange County, it exists now as above stated, having been passed by the Supervisors of that County, to whom the de. partment of Game Laws has recently been entrusted by an act of the State Legislature.

March, 1851. 


\section{RAIL; AND RAIL SHOOTING.}

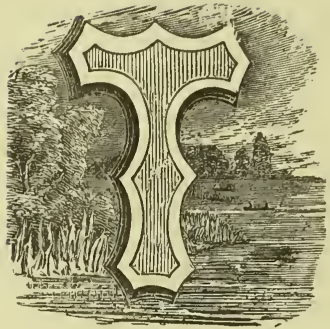

HIS singular and delicious little bird is so peculiar in its character and habits, although of an order which affords several species of our most esteemed game, viz.: Grallatores, and the mode of pursuing and shooting it is so distinct from any other kinds of sport, that I have judged it best to keep it under a head entirely separate from other field sports, with no one of which, in truth, has it the smallest connexion or alliance.

"Rallus Carolinus-Ortygometra Carolinus-the Carolina Railthe Sora Rail-vulgo, the Rail.

"Male 93.14 .

"Passes across the United States, both by the interior and along the coast. Some breed in New Jersey. Rarely seen east of Massachusetts. Extremely abundant in autumn on the Delaware and other streams furnished with wild oats. A few reside in Florida and Louisiana in winter.

"Adult male.

"Bill shorter than the head, rather stout, deep, compressed, tapering. Upper mandible with the dorsal outline nearly straight, being slightly convex toward the end, the ridge flattish for a very short space at the base, very slightly extended on the forehead, narrow in the rest of its extent; the sides convex toward the end, the edges sharp, inflected, with a slight sinus 
close to the tip. Nasal groove broad, and extending to twothirds of the length of the bill. Nostrils linear, lateral, submedial, pervious. Isower mandible with the angle long and narrow, the sides erect, the dorsal line sloping upward, the edges inflected, the tip narrowed, the gap line straight.

"Head rather small, oblong, compressed. Neck of moderate length. Body rather slender, much compressed. Feet of moderate length, rather stout; tibia bare a short way above the joint; tarsus of ordinary length, compressed, anteriorly covered with broad scutella, posteriorly with smaller, and on the sides reticulated. Hind toe very short and slender, middle toe longest, and longer than the tarsus, fourth considerably shorter than the third, and a little longer than the second; toes free, scutellate above, much compressed, with an inferior sharp margin. Claws rather long, exceedingly compressed, slightly arched, tapering to a fine point, flat, and marginate beneath.

"Plumage rather stiff, but blended, slightly glossed above. Feathers of the forehead with the shaft enlarged and slightly extended beyond the tip. Wings short and broad. Alula large ; primaries curved, broad, tapering, but rounded, second longest, third scarcely shorter, first equal to sixth; secondaries broad and rounded. Tail extremely short, much rounded, of twelve feeble rounded feathers; the upper and lower tail coverts nearly as long as the tail feathers.

"Bill, yellow at the base, dusky toward the end. Iris bright chestnut. Feet yellowish-green; claws light-brown. A broad band surrounding the base of the bill, the central part of the crown, the chin, and the fore-neck in its whole length, brownish-black. Ear coverts olive-brown; a band over the eye, the cheeks and the sides of the neck ash-grey. Sides of the crown, the hind-neck, and the rest of the upper parts olive-brown. The feathers brownish-black in the centre, those on the back with two marginal lines of white. Smaller wing coverts of a lighter brown; secondary coverts margined with black and white markings; quills dusky olive-brown, as is the tail. Middle of breast and abdomen greyish-white; sides barred with brownish- 
black and greyish-white, as are the lateral feathers of the rurnp; those of the abdomen reddish-yellow.

"Length to end of tail, $9 \frac{3}{12}$ inches; to end of wings, $8 \frac{3}{4}$; to end of claws, 12 ; extent of wings, 14 ; wing from flexure, $4 \frac{8}{12}$; tail, 2; bill along the ridge, $\frac{10}{12}$; along the edge of the lower mandible, $\frac{10}{12}$; tarsus, $1 \frac{3}{12}$; its middle toe, $1 \frac{7}{12}$; its claw, $4 \frac{1}{24}$. Weight, $7 \mathrm{oz}$.

"Adult female.

"The female differs considerably from the male in coloring. The naked parts and iris are similar, as are the upper parts generally; but the black around the base of the bill, on the head and fore-neck, is wanting, the fore parts of the head being light-brown, the chin whitish, the sides of the neck light greyish-brown. The white lines of the back are duller, and the dark bands of the sides of a lighter tint.

"Young male.

"The young male, after its first moult, is intermediate in color between the adult male and the female, but more like the latter, the black on the head and fore-neck appearing in spots, and the sides of the neck being nearly as in the female." Audubon's Birds of America.

"Of all our land or water fowl, perhaps none afford the sportsman more agreeable amusement or a more delicious repast than the little bird now before us. This amusement is indeed temporary, lasting only two or three hours in the day, for four or five weeks in each year, but as it occurs in the most agreeable and temperate of our seasons, is attended with little or no fatigue to the gunner, and is frequently successful, it attracts numerous followers, and is pursued in such places as the birds frequent, with great eagerness and enthusiasm.

"The natural history of the Rail, or as it is called in Virginia the Sora, and in South Carolina the Coot, is to the most of our sportsmen involved in profound and inexplicable mystery. It comes they know not whence, and goes they know not where. No one can detect their first moment of arrival; yet all at once 
the reedy shores and grassy marshes of our large rivers swarm with them, thousands being sometimes found within the space of a few acres. These, when they do venture on wing, seem to fly so feebly, and in such short fluttering flights among the reeds, as to render it highly improbable to most people that they could possibly make their way over an extensive tract of country. Yet on the first smart frost that occurs, the whole suddenly disappear, as they had never been.

"To account for these extraordinary phenomena, it has been supposed by some that they bury themselves in the mud, but as this is every year dug up into ditches, by people repairing the banks, without any of these sleepers being found, where but a few weeks before these birds were innumerable, this theory has been abandoned. And here their researches into this mysterious matter, generally end in the common exclamation of, What can become of them? Some profound inquirers, however, not discouraged with these difficulties, have prosecuted their researches with more success, and one of these being a few years ago near the mouth of James River, in Virginia, where the Rail, or Sora, are extremely numerous, has, as I was informed on the spot, lately discovered that they change into Frogs, having himself found in his meadows an animal of an extraordinary kind, that appeared to be neither a Sora nor a Frog, but, as he expressed it, something between the two. He carried it to his negroes, and afterwards took it home, where it lived three days, and in his own, and in his negroes' opinion, it looked like nothing in this world but a real Sora changed into a Frog! What farther confirms this grand discovery, is the wellknown circumstance of the Frogs ceasing to halloo as soon as the Sora comes in the fall.

"This sagacious discovery, however, like many others renowned in history, has found but few supporters, and except his own negroes, has not, as far as I can learn, made a single convert to his opinion.

"Matters being so circumstanced, and some explanation necessary, I shall endeavor to throw a little more light on the 
subject by a simple detail of facts, leaving the reader to form his own theory as he pleases.

"The Rail, or Sora, belongs to a genus of birds of which about thirty different species are enumerated by naturalists, and these are distributed on almost every region of the habitable parts of the earth. The general character of these is every where the same. They run swiftly, fly slowly and usually with the legs hanging down, become extremely fat, are fond of concealment, and whenever it is practicable, prefer running to flying. Most of them are migratory, and abound during the summer in certain countries, the inhabitants of which have very rarely an opportunity of seeing them. Of this last, the Land Rail of Britain is a striking example. This bird, which during the summer months may be heard in almost every grass and clover field in the kingdom, uttering its common note, 'crek, crek,' from sunset to a late hour in the night, is yet unknown by sight to more than nine-tenths of the inhabitants.

"Its well-known cry, says Bewick, is first heard as soon as the grass becomes long enough to shelter it, and continues till the grass is cut, but the bird is seldom seen, for it constantly skulks among the thickest part of the herbage, and runs so nimbly through it, winding and doubling in every direction, that it is difficult to come near it. When hard pushed by the dog, it sometimes stops short and squats down, by which means its too eager pursuer overshoots the spot and loses the trace.

" It seldom springs, but when driven to extremity, and generally flies with its legs hanging down, but never to a great distance ; as soon as it alights it runs off, and before the fowler has reached the spot the bird is at a considerable distance.

"The Water-crake, or Spotted Rail of the same country, which in its plumage approaches nearer to our Rail, is another notable example of the same general habit of the genus. Its common abode, says the same writer, is in low, swampy grounds, in which are pools or streamlets overgrown with willows, reeds and rushes, where it lurks and hides itself with great circumspection. It is wild, solitary and sly, and will 
swim, dive and skulk under any cover, and sometimes suffer itself to be knocked on the head, rather than rise before the sjortsman and his dog. The Water Rail of the same country is noted for the like habits. In short, the whole genus possess this strange family character in a very remarkable degree.

"These three species are well known to migrate into Britain early in the spring, and to leave it for the more southern parts of Europe in autumn. Yet they are rarely or never seen in their passage to or from the countries, where they are regularly found at different seasons of the year, and this for the very same reasons, that they are so rarely seen even in the places they inhabit. It is not, therefore, at all surprising, that the regular migrations of the American Rail, or Sora, should in like manner have escaped notice in a country like this, whose population bears so small a proportion to its extent, and where the study of natural history is so little attended to. But that these migrations do actually take place, from north to south, and vice vers $\hat{A}$, may be fairly inferred from the common practice of thousands of other species of birds, less solicitous of concealment, and also from the following facts :-

"On the 22d day of February, I killed two of these birds in the neighborhood of Savannah, in Georgia, where they have never been observed during the summer. On the second day of the May following, I shot another in a watery thicket, below Philadelphia, between the rivers Schuylkill and Delaware, in what is usually called the Neck. This last was a male in full plumage. We are also informed that they arrive at Hudson's Bay early in June, and again leave that settlement for the South early in autumn.

"That many of them also remain here to breed, is proved by the testimony of persons of credit and intelligence, with whom I have conversed, both here and on James River, in Virginia, who have seen their nests, eggs, and young. In the extensive meadows that border the Schuylkill and Delaware, it was for- . merly common, before the country was so thickly settled, to find young Rail in the first mowing time, among the grass 
Mr. James Bartram, brother to the botanist, a venerable and still active man, of eighty-three, and well acquainted with this bird, says, that he has often seen and caught young Rail in his own meadows, in the month of June; he has also seen the nest, which, he says, is usually in a tussock of grass, is formed of a little dry grass, and had four or five eggs of dirty whitish color, with brown, or blackish spots. The young run off as soon as they break the shell, are then quite black, and run about among the grass, like mice. The old ones he has very rarely observed at that time, Lut the young often. Almost every old settler along these meadows, with whom I have conversed, has occasionally seen young Rail in mowing time, and all agree in describing them as covered with blackish down. There can, therefore, be no reasonable doubt as to the residence of many of those birds, both here and to the northward, during the summer.

"That there can be as little doubt as to their winter retreat, will appear more particularly towards the sequel of the present account.

" During their residence here in summer, their manners exactly correspond with those of the Water-crake of Britain, already quoted, so that though actually a different species, their particular habits, common places of resort, and eagerness for concealment, are as nearly the same as the nature of the climates will admit.

"Early in August, when the reeds along the shores of the Delaware have attained their full growth, the Rail resort to them in great numbers, to feed on the seeds of this plant, of which they, as well as the Rice-birds, and several others, are immoderately fond. These reeds, which appear to be the Zizania panicula effusa of Linnæus, and the Zizania clavulosa of Willinden, grow up from the soft muddy shores of the tide-water, which are, alternately, dry, and covered with four or five feet of water. They rise with an erect tapering stem, to the height of eight or ten feet, being nearly as thick below as a man's wrist, and cover tracts along the river for many acres. The cattle feed on their long, green leaves, with avidity, and wade in aftes 
them as far as they dare safely venture. They grow up so close together, that except at or near high water, a boat can with difficulty make its way through among them. The seeds are produced at the top of the plant, the blossoms, or male parts, occupying the lower branches of the pannicle, and the seeds the higher. The seeds are nearly as long as a common-sized pin, somewhat more slender, white, sweet to the taste, and very nutritive, as appears by their effects on the various birds that feed on them at this season. When the reeds are in this state, and even while in blossom, the Rail are found to have taken possession of them in great numbers. These are generally numerous, in proportion to the full and promising crop of the former. As you walk along the embankment of the river, at this season, you hear them squeaking in every direction, like young puppies. If a stone be thrown among the reeds, there is a general outcry, and a reiterated $k u k, k u k, k u k$, - something like that of a Guinea-fowl. Any sudden noise, or discharge of a gun, produces the same effect. In the meantime, none are to be seen, unless it be at or near high water,-for when the tide is low, they universally secrete themselves among the interstices of the reeds; and you may walk past, and even over them, where there are hundreds, without seeing a single individual. On their first arrival, they are generally lean and unfit for the table, but as the seeds ripen, they rapidly fatten, and from the 20th September to the middle of October, are excellent, and eagerly sought after. The usual method of shooting them in this quarter of the country, is as follows.

"The sportsman furnishes himself with a light batteau, and a stout, experienced boatman, with a pole of twelve or fifteen feet long, thickened at the lower end, to prevent it from sinking too deep in the mud. About two hours or so before high water, they enter the reeds, and each takes his post,- the sportsman standing in the bow, ready for action, the boatman on the sternseat, pushing her steadily through the reeds. The Rail generally spring singly as the boat advances, and at a short distance a-head, are instantly shot down, while the boatman, keeping 
his eye on the spot where the bird fell, directs the boat forward, and picks the bird up, while the gunner is loading. It is also the boatman's business to keep a sharp look-out, and give the word 'Mark,' when a Rail springs on either side, without being observed by the sportsman, and to note the exact spot where it falls, until he has picked it up ; for this once lost sight of, owing to the sameness in the appearance of the reeds, is seldom found again. In this manner the boat moves steadily through and over the reeds, the birds flushing and falling, the gunner loading and firing, while the boatman is pushing and picking np. The sport continues an hour or two after high water, when the shallowness of the water, and the strength and weight of the floating reeds, as also the backwardness of the game to spring, as the tide decreases, oblige them to return. Several boats are sometimes within a short distance of each other, and a perpetual cracking of musketry prevails above the whole reedy shores of the river. In these excursions, it is not uncommon for an active and expert marksman to kill ten or twelve dozen in a tide. They are usually shot singly, though I have known five killed at one discharge of a double-barrelled piece. These instances, however, are rare. The flight of these birds among the reeds, is usually low, and shelter being abundant, is rarely extended to more than fifty or one hundred yards. When winged, and uninjured in their legs, they swim and dive with great rapidity, and are seldom seen to rise again. I have several times, on such occasions, discovered them clinging with their feet to the reeds under the water, and at other times skulking under the floating reeds, with their bills just above the surface; sometimes, when wounded, they dive, and rising under the gun wale of the boat, secrete themselves there, moving round as the boat moves, until they have an opportunity of escaping unnoticed. They are feeble and delicate in everything except the legs, which seem to possess great vigor and energy; and their bodies being so remarkably thin, are compressed so as to be less than an inch and a quarter through transversely, they are enabled to pass between the reeds like rats. When seen, they are 
almost constantly jetting up the tail, yet though their flight among the reeds seem feeble and fluttering, every sportsman who is acquainted with them here, must have seen them occasionally rising to a considerable height, stretching out their legs behind them, and flying rapidly across the river, where it is more than a mile in width. Such is the rnode of Rail shooting in the neighborhood of Philadelphia.

"In Virginia, particularly along the shores of James River, within the tide water, where the Rail, or Sora, are in prodigious numbers, they are also shot on the wing, but more usually taken at night in the following manner:-

"A kind of iron grate is fixed on the top of a stout pole, which is placed like a mast in a light canoe, and filled with fire. The darker the night, the more successful is the sport The person who manages the canoe, is provided with a light paddle, ten or twelve feet in length; and about an hour before high water, proceeds through among the reeds, which lie broken and floating on the surface. The whole space, for a considerable way round the canoe, is completely enlightened,- - the birds start with astonishment, and, as they appear, are knocked over the head with a paddle, and thrown into the canoe. In this manner, from twenty to eighty dozen have been killed by three negroes in the short space of three hours.

"At the same season, or a little earlier, they are very numerous in the lagoons near Detroit, on our northern frontier, where another species of reed, of which they are equally fond, grows in shallows in great abundance. Gentlemen who have shot them there, and on whose judgment I can rely, assure me that they differ in nothing from those they have usually killed on the shores of the Delaware and Schuylkill; they are equally fat and exquisite eating.

"On the seacoast of New-Jersey, where these are not to be found, this bird is altogether unknown, though along the marshes of Maurice River, and other tributary streams of the Delaware, and where the reeds abound, the Rail are sure to be found also. Most of them leave Pennsylvania before the end of 
October, and the Southern States early in November, though numbers linger in the warm southern marshes the whole winter.

"A very worthy gentleman-Mr. Harrison-who lives in Kittiwan, near a creek of that name, on the borders of James River, informed me, in burning his meadows early in March, they generally raise and destroy several of these birds.

"That the great body of these Rail winter in countries beyond the United States, is rendered highly probable, from their being so frequently met with at sea, between our shores and the West India Islands.

"A Captain Douglas informed me, that on his voyage from St. Domingo to Philadelphia, and more than a hundred miles from the Capes of the Delaware, one night the man at the helm was alarmed by a sudden crash on deck, that broke the glass in the binnacle, and put out the light. On examining into the cause, three Rail were found on deck, two of which were killed on the spot, and the other died soon after.

"The late Bishop Madison, President of William and Mary College, Virginia, assured me that a Mr. Skipwith, for some time our Consul in Europe, on his return to the United States, when upwards of three hundred miles from the Capes of the Chesapeake, several Rail, or Soras, I think five or six, came on board, and were caught by the people. Mr. Skipwith being well acquainted with the bird, assured him that they were the very same with those usually killed on James River.

"I have received like assurances from several other gentlemen, and captains of vessels, who have met with those birds between the main land and the islands, so as to leave no doubt on my mind as to the fact. For why should it be considered incredible, that a bird which can both swim and dive well, and at pleasure fly with great rapidity, as I have myself frequently witnessed, should be incapable of migrating, like so many others, over extensive tracts of land or sea? Inhabiting as they do the remote regions of Hudson's Bay, where it is impossible they could subsist during the rigor of the winter, they must either emigrate from there, or perish; and as the same places in Penn- 
sylvania, which abound with them in October, are often laid under ice and snow during the winter, it is as impossible that they could exist here in that inclement season. Heaven has, therefore, given them, in common with many others, certain prescience of these circumstances, and judgment, as well as strength of flight, sufficient, to seek more genial climate, abounding with the suitable food.

"During the greater part of the months of September and October, the market of Philadelphia is abundantly supplied with Rail, which are sold from half a dollar to a dollar per dozen. Soon after the 20th of October, at which time our first smart frosts generally take place, these birds move off to the South. In Virginia they usually remain until the first week in November.

"Since the above was written, I have received from Mr. George Ord, of Philadelphia, some curious particulars relative to this bird, which, as they are new, and come from a gentleman of respectability, are worthy of being recorded, and merit further investigation.

“' My personal experience,' says Mr. Ord, 'has made me acquainted with a fact in the history of the Rail, which, perhaps, is not generally known,- and I shall as briefly as possible communicate it to you. Some time in the autumn of the year 1809, as I was walking in a yard, after a severe shower of rain, I perceived the feet of a bird projecting from a spout. I pulled it out, and discovered it to be a Rail, very vigorous, and in perfect health. The bird was placed in a small room, on a gun case, and I was amusing myself with it, when in the act of pointing my finger at it, it suddenly sprang forward, apparently Inuch irritated, fell to the floor, and stretching out its feet, and bending its neck, until the head nearly touched the back, became to all appearance lifeless. Thinking the fall had killed the bird, I took it up, and began to lament my rashness, in provoking it. In a few minutes it again breathed, and it was some time before it perfectly recovered from the fit into which it now appeared evident it had fallen. I placed the Rail in a room 
wherein Canary Birds were confined, and resolved that on the succeeding day, I would endeavor to discover whether or not the passion of anger had produced the fit. I entered the room at the appointed time, and approached the bird, which had retired on beholding me, in sullen humor, to a corner. On pointing my finger at it, its feathers were immediately ruffled, and in an instant it sprang forward, as in the first instance, and fell into a similar fit. The following day the experiment was repeated, with like effect.

" 'In the fall of 1811 , as I was shooting among the reeds, I perceived a Rail rise but a few feet before my batteau. The bird had risen about a yard, when it became entangled in the tops of a small bunch of reeds, and immediately fell. Its feet and neck were extended, as in the instances above mentioned, and before it had time to recover, I killed it. Some few days afterwards, as a friend and I were shooting in the same place, he killed a Rail, and as we approached the spot to pick it up, another was perched not a foot off, in a fit; I took up the latter and placed it in the crown of my hat; in a few moments it revived, and was as vigorous as ever.

" "These facts go to prove that the Rail is subject to gusts of passion, which operate to so violent a degree as to produce a disease similar in its effects to epilepsy. I leave the explanation of the phenomena to those pathologists who are competent and willing to investigate it. It may be worthy to remark that the birds affected as described, were all females, of the Gallinula Carolina, or common Rail'

"The Rail, though generally reputed a simple bird, will sometimes manifest symptoms of considerable intelligence. To those acquainted with Rail shooting, it is hardly necessary to mention that the tide in its flux is considered an almost indispensable auxiliary, for when the water is off the marsh, the lubricity of the mud, the height and compactness of the reed, and the swiftness of foot of the game tend to weary the sportsman and to frustrate his endeavors.

"Even should he succeed in a tolerable degree, the reward is 
not commensurate to the labor. I have entered the marsh in a batteau, at a common tide, and in a well-known haunt, have beheld but a few birds. The next better tide, on our resorting to the same spot, I perceived abundance of game. The fact is, the Rail dive and conceal themselves beneath the fallen reed, merely projecting their heads above the surface of the water for air, and remain in that situation until the sportsman has passed them, and it is well known that it is a common practice with wounded Rail to dive to the bottom, and holding on to some vegetable substance, support themselves in that situation until exhausted.

"During such times, the bird, in escaping from one enemy has often to encounter with another not less formidable. Eels and cat-fish swim in every direction seeking for prey, and it is ten to one if a wounded Rail escaie them. I myself have beheld a large eel make off with a bird that I had shot, before I had time to pick it up ; and one of my boys, in bobbing for eels, caught one with a whole Rail in its belly. I have heard it observed that on the increase of the moon the Rail improves in fatness, and decreases in a considerable degree with that planet. Sometimes I have conceited that the remark was just. If it be a fact, I think it may be exp'ained on the supposition that the bird is enabled to feed at night as well as by day, while it has the benefit of the moon, and with less interruption than at other periods.

"I have had my doubts as to the propriety of classing this bird under the genus Rallus. Both Latham and Pennant call it a Gallinula, and when one considers the length and formation of its bill, the propriety of the nomenclature is obvious.

"As the article was commenced by our printers before I could make up my mind on the subject, the reader is requested to consider this species the Gallinula Carolina of Dr. Latham."Wilson's American Ornithology.

To set aside the possibility of continued doubt on the subject of the migration of the Rail, which really seems to be so perVOL. I. 
fectly a settled question, as to render it impossible that any sane man in America should persist in believing that this bird burrows and lies torpid in the mud-I have myself, however, met scores who do believe so-I shall quote Mr. Audubon's personal observations as to the migrations of this bird, which he has often seen with his own eyes, and no one, who has read his delightful animal biographies, will doubt how keen those eyes are, and how accurate.

"This bird," he says, "which I think might have been named the Pennsylvanian or Virginian Rail, enters the union from the shores of Mexico, early in March, when many are seen in the markets of New Orleans. Some reach their northern destination by ascending along the margin of our western streams, or by crossing the country directly, in the manner of the Woodcock; while those which proceed along the coast shorten their journey as much as possible by flying across the headlands of the numerous inlets or bays of our southern districts, returning or advancing more slowly, according to the state of the weather. Thus, those which cross the peninsula of Florida, through the marshes and lagoons which lead to the head waters of the St. John's River, instead of travelling round the shores of Georgia and South Carolina, fly directly across toward Cape Lookout. It is nevertheless true, that a certain number of these birds follow the sinuosities of the shores, for I found some in the markets of Charleston, in April, that had been killed in the immediate neighborhood of that city, and I obtained others in various parts; but the number of these is very small as compared with those that cross at once. When their passage takes place, either during calm weather, or with a favorable wind, the fortunate travellers pursue their journey by entering Pamlico Sound, and following the inner margins of the outward banks of this part of the coast until they reach Cape Henry Thence some ascend the Chesapeake, while others make for the mouth of the Delaware, and these, perhaps, again meet on the borders of Lake Ontario, or the waters of the St. Lawrence, 
after which they soon enter those portions of the country in which they breed, and spend a short but agreeable season.

"Every person acquainted with the general movements of birds, either during the spring, when they pass northward, or the autumnal months, when they are on their way to milder climes, is aware that at the former period their anxiety to reach the breeding place is much greater than that which they feel at any other period. Thus, in its movement southward, the Sora, like all other Rails, when returning with its progeny, which are yet feeble, and unable to undergo much fatigue, proceeds considerably slower than in spring; hence its appearance in autumn, in multitudes, in various places, where it is enticed, by an abundance of food and comparative security, to tarry for some time and recruit its strength. Thus in September and part of October, the Sora is found in great numbers on the borders of our great lakes, feeding on wild oats, and on the reedy margins of the rivers of our middle districts. Several natural causes prevent birds of this species from following the seacoast of the United States while migrating, either in spring or in autumn, the principal of which is the absence of their favorite Zizania marshes, which are but very rarely to be met with to the east of the State of New-York. This is probably the cause of the great rarity of this species in Massachusetts, while, so far as I know, none are ever found to the eastward of that State. These observations are corroborated by those of my friend, Thomas McCulloch, of Pictou, who never met with one of these birds during many years' residence in that part of Nova Scotia.

"Having seen flocks of Soras winging their way close over the waters of the gulf of Mexico, and between Cape Florida and the main shores of the Carolinas, in the month of April, when they were moving directly toward Cape Lookout, I have very little doirbt that many return in the same track, in the end of October, when the young, well-fed and strengthened, are able to follow their parents on wing, even across that wide expanse of water. I shall now dismiss this part of the sub:ect by add- 
ing in confirmation of their capability of protracted flight, that some of these birds, when accidentally separated from their flock, have supported themselves on wing until they have met with vessels several hundred miles from land; and facts of this kind have been announced by persons of well-known respectability.

"During the autumnal months, a goodly number of Soras are found in the rice fields and fresh water marshes of the Carolinas. Sometimes, also, they have been shot in salt water marshes, in spring, while on their northward migration. At this period they are silent until forced to fly. In those States, none are seen during summer, very few, it appea!s, remain in any part of the middle districts. My friend, John Bachman, however, was shown some eggs of this bird, that had been found in the meadows below Philadelphia; and whilst I was on a shooting expedition for Woodcock, in company with my friend, Edward Harris, Esq., my son shot some young birds, scarcely fledged, and shortly afterward, an adult female. John Bachman met with a nest on the shores of the Hudson, and I saw two in the marshes of Lake Champlain."-Audubon's American Ornithology.

I have judged it but proper to extend both my quotations on the habits, and my own observations on the shooting of this bird, to some length, as the first are very peculiar, and the latter affords a sport, which though I think it for my own part, rather a tame amusement, is still followed with much eagerness and zest by sportsmen, especially on the Delaware, and on the great Western Lakes, where the bird, as we have seen, abounds.

The United States contain many other species of Rail, most of which are at times shot by the sportsman, while in pursuit of one kind or another of aquatic fowl, but none of them are sufficiently abundant, in certain spots or at certain seasons, unless it be perhaps the bird commonly known as the Mud-Hen, to le made the object of especial pursuit. 
T'his bird which is, properly,

The Clapper Rail, or Salt Water Marsh Hen, RalLus Crepitans, is a constant resident at one period or other of the year, on some part of the Atlantic coasts from Long Island to the Gulf of Mexico. It is a large-sized bird, weighing 11 to $12 \mathrm{oz}$., and looking much larger than it really is. They are shot in the bays of Long Island, and still more abundantly in the vicinity of Charleston, much as the Sora Rail is on the Delaware; the boats are, however, in this sport, if it can be so called-for the birds are large, clumsy, slow-moving and cannot be missed-propelled by oars or paddled, not by the pole. On Long Island and generally in the Middle States, this bird is called the Mud, or Meadow-Hen.

The other species commonly met with by the sportsman are, The Great Red-Breasted Rail, or Fresh Water Marsh Hen-Rallus Elegans-commonly known in Pennsylvania and New-Jersey as the "King RaIL."

This is the largest and by far the handsomest of the tribe; its weight is about 11 to $13 \mathrm{oz}$.- -its length $20 \frac{1}{2}$ inches by an alar extent of 22 .

It is rarely found east of Pennsylvania, although I have occasionally killed it in New-Jersey. It is a constant resident of the Southern States.

The Virginia Rail-Rallus Virginianus. This bird greatly resembles the last species, though not much more than half its size. It is properly a Southern bird, but is found during the autumn, in small numbers along the atlantic coasts. It is killed both on fresh and salt water, but is nowhere exceedingly abundant.

In addition to these, I may name the common Coot of Ameri$\mathrm{ca}$, and the common Gallinule, both of this same family of RAI.LIDE. They are principally Southern birds, though stragglers are occasionally found in the Middle and Eastern States. They are of little worth for the sport which they afford, and still less for the quality of their flesh; but like many other water birds and waders, such as the Bitterns, Herons, Egrets, and the 
like, are usually killed by the sportsman, if encountered in pursuit of other game, though never made the object of especial chase.

None of these, however, can it be deemed unsportsmanlike or snobbish to shoot, while in the field, with dogs, as it is to kill Pigeons, Meadow Larks, Thrushes, or the like, since their haunts and habits are generally in some sort like game-like, and dogs will, for the most part, draw on them, if not stand them dead.

None of these, however, require any fuller notice than the above, and hence I proceed to shooting the Sora Rail on the Delaware. 


\section{RAIL SHOOTING.}

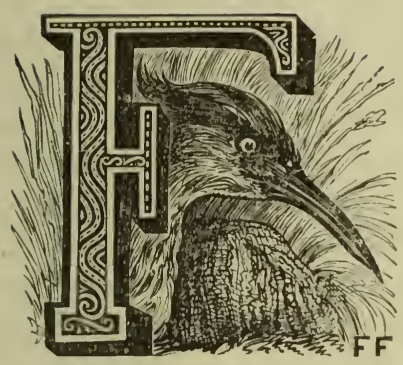

ROM the middle of August, until the setting in of wintry frosts, the pursuit of this curious, and excellent little bird, may be followed in the localities which he frequents, by those who care for the sport.

It is not by any means comparable to those kinds of shooting, which are followed with dogs in the field, among varied scenery and diverse accidents of sport ; nor is the bird very sporting in its habits, nor is much skill required to shoot him.

$\mathrm{He}$ is, however, delicious to eat; he literally abounds on the reedy mud-flats of those rivers which he affects; and his season is one at which there is little or no other occupation for the sportsman. So that, between the epicurean desire for his flesh, the absence of more agreeable and exciting sport, and the very easiness of the pursuit, which, to young hands and bad shots, is a recommendation, the Rail is very eagerly pursued; and during those periods of the tide, which permit his pursuit, a stranger might well believe, during the Rail season, almost anywhere on the Delaware, sixty miles below, or thirty above Philadelphia, that the outposts of two armies were engaged in a brisk skirmish, so incessant is the rattle of small arms.

It is the habit of this little bird to skulk and run among the reeds and water-oats of the flats which he inhabits; and, owing to the peculiar form of his long, flat-sided, wedge-like body, with the legs situated far behind, and the wings closely com 
pressed, he can pass with such ease and celerity among the close stalks of the water-plants, that the sharpest dogs cannot compel him to take wing; and so thoroughly is he aware of this advantage which he possesses, and of the peril he runs in rising before the gun, that it is utterly useless to attempt beating for him with dogs on foot, or to think of walking, or kicking him up from his lurking places, when the tide is down.

As soon, however, as it has risen high enough to allow a boat to be forced through the partially submerged, partially floating grass, unable to run, from want of a solid substructure on which to tread, or to swim, from the denseness of the vegetation, he has no choice but to rise, which he does reluctantly, and not until the bows of the boat are close upon him.

His flight is then slow and heavy, with the legs hanging down, and the wings heavily flapping, and it is rarely protracted to above thirty or forty yards of distance. It is exceedingly easy to kill him, therefore; so much so, that as soon as he mastered the slight difficulty of getting accustomed to the motion of the boat, and got what a sailor would call his sea legs on board, the merest tyro, who can cover a bird on the wing in the slowest conceivable motion, and pull an inexpert trigger, can scarce fail to bag many of these birds in succession.

The boat used is a long, light, flat-bottomed, sharp-built skiff, -flat to draw as little water as possible, sharp to force its way through the heavy tangled water-plants. In the bow of this the shooter stands erect, balancing himself in the ricketty rocking egg shell, for it is little more, while the pole-man stands behind him, propelling the vessel with his long punt-pole, the more rapidly the better, through the weeds and grass.

The pole-man's duty is to steer and urge the boat, both of which are done by the same instrument, to mark the dead birds, and collect them, and to get the advantage of all other boats for his shooter. This marking is by no means an easy task; as the vast expanse of level green herbage afiords no points, or marks, by which to identify the spot where the bird has fallen; and, moreover, the reeds and grass are so thick, and so similar in 
color to the plumage of the Rail, that unless it is marked with the most perfect accuracy, literally to a foot's space, it is almost useless to look for it. So many boats, moreover, are darting about in all directions, the rival pole-men driving their skiffs with all attainable velocity, and the emulous shooters banging away at the thick-rising birds, without much caring whether some other sportsman be or be not within the range, and in the line of shot, that in order to get good sport, not a moment must be lost in bagging the dead birds,-cripples it is impossible to bag, so quickly do they dive, and so cunningly do they skulk,and that at best it is a matter of some little risk.

Fortunately, the bird is so easily killed, and the range of his flight is so small, that very light charges, and very small shot, are in use. With the recklessness I have seen displayed in this sport, were large charges, and heavy shot used, it would be an affair of real danger to shoot at Dullman's Flats, at the mouth of the Neshaminy, or at Perkins' Flats, or Newbold's Islandthe best places above Philadelphia, on the Delaware, and the only places, with the exception of a small flat, of an acre or two in extent, before my own door on the Passaic, where I have ever shot Rail.

The great onus and excellence of the sport depends, as it will readily be seen, on the pole-man, or pusher, and with two equally good shots, it shall make a difference of nearly half the bag, which has the better assistant. The skill at marking dead birds, the rapidity of bagging them, and the adroitness at pushing, to which some of these men attain, is truly remarkable; and accustomed to the society of gentlemen, and provided with a good stock of sporting anecdote, and sporting information, they are generally very conversable, and discreet fellows, with whom a few hours can be spent, not only without tedium, but with some profit.

John Horn, of Bristol, in Pennsylvania, is the best hand of these hardy aquatics I have ever encountered, and many a good day's sport and fun have I enjoyed in his company, and under his guidance, on the brond and tranquil Delaware. 
The time for beginning this sport depends on the depth of water on the particular flat whereon you are about to try your fortune,- the moment the rising tide will permit your hoat to run over and through the reeds, you must commence; and your sport will continue so long as the birds will continue to rise before you, which will generally be until about the first quarter of the ebb; but as the water falls, the Rail become less and less willing to take wing,-and in similar positions of the rising and falling tide, you shall flush twice as many when it is making.

There is little more to be said, on the head of this sport, ex. cept to give a few hints as to accoutrements and equipage, on which, perhaps, next to the merits of your pole-man, the celerity of your shooting, and amount of your bag, will depend.

The best position, as I have observed, for the shooter, is to stand,-and the best way to do this in the tottering and fragile skiffs, is to plant the feet firmly a little way apart, with the left somewhat advanced; not to brace your legs, or stiffen your knees, but rather to let the latter be a little bent, and to humor the motion of the boat, by swaying your body slightly in accordance with it.

It does not much matter, however, except so far as you dread a ducking, reader mine, whether you chance to get overboard, or no, for the sport is pursued, invariably, in the shallowest of water, and drowning is out of the question, in the worst event.

As the weather is generally warm, a light shooting-jacket, and straw hat, are as appropriate a dress as any. Your shortest and your lightest gun, is the best tool for the sport; but a largish landing-net, on a long, light pole, will be found a very convenient appendage, and will save your pole-man much time in bringing your dead birds to bag.

Next, as regards loading, to do which very quickly-at all times a great point, is here a sine quâ non to good sport-use no shot-bag, and put the charger of your powder-horn down to its minimum of contents. Half the ordinary charge of powder, and three-quarters of an ounce of No. 9 shot, is an ample charge for Rail. But if you are looking out for flock shooting at Reed- 
birds at the same time, as is usual, it is well to carry a second heavier gun, with an ordinary load of No. 8. Sometimes Teal, or other wild duck, come across you, especially while going up or down the river to your ground, or returning from it; and for the chance of these, it is well to reserve a barrel, if not a gun, loaded with Eley's cartridges of No. 3 or 4.

For greater convenience of loading, as you are always stationary in one place, and have abundant space for conveniences, you will find it well to have a square wooden box, with two compartments, one capable of containing eight or ten pounds of shot, and the other a quantum suff. of wadding; a small tin scoop of the capacity named above, three-quarters of an ounce, lying on the shot, will save much trouble, and half the time in load. ing. This box, and your powder-horn, will lie on the bench or thwart before you,-your copper caps you will keep in your waistcoat-pocket; and by the precaution of being thus provided aforehand, you will get three shots for two with a rival, who lugs his flask out of his pocket, and charges with a belt or pouch after every shot.

No farther rules are needed, except the old one, which cannot be too often repeated,-take your time, and be deliberate. Nay ! with the Rail you can afford to be slow, for he shall rise within ten feet of you, ninety-nine times of a hundred, and you shall miss him only by getting flurried, or by tumbling overboard.

For the rest, though it really scarce deserves to be rated as a sport, or honored with a place among the nobler kinds of woodcraft, Rail shooting is a pretty pastime enough ; and when birds are abundant, and rise well, the rapid succession of shots, and the necessary rapidity of motion, creates an excitement, io which is often added the emulation of surpassing rival boats and gunners,- to which may again be superadded the stimulating apprehension of being peppered soundly by a stray charge of mustard-seed, together with the agreeable variations of vituperation and recrimination, to which the said peppering may be expected to give rise. 
The Rail is, as I observed before, capital eating. He is to be cooked and served exactly as the Snipe, with no sauce or condiment whatever, but his own gravy caught upon a slice of crisp buttered toast, and a sprinkle of salt. Like all water-birds, he is to be eaten fiesh, the sooner after killing the better ! Twentyfour hours dead, he is not only ancient, but fish-like. Red wine is the liquor wherein he should be laid at rest within the inner man, as unquiet ghosts in a red sea! Peace to him! He shall sit lightly on your stomach, even if partaken at a rere supper.

A lew words, hereafter, concerning wild-fowl shooting in upland brooks, or stalking them on inland lakes, or pools, and [ have finished my task, in so much as relates to Upland shooting. 
UPLAND SHOOTING.

\section{DUCK SHOOTING, ON INLAND WATERS.}

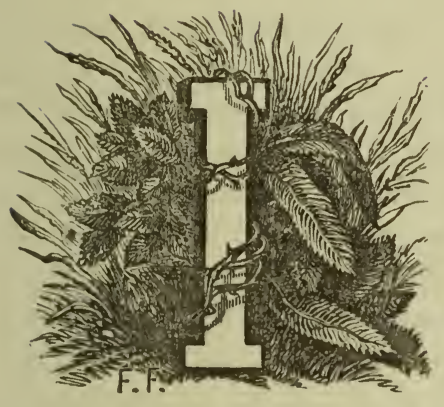

$\mathrm{N}$ the Eastern and Midland States, unless on the borders of the great lakes, this sport of late years can hardly be said to exist at all. The birds are becoming rare and wild, and, although still shot in sufficient numbers by the local gunners, on the streains of New-Jersey, to supply the demand of the markets, they are not found numerous enough to justify the pursuit of the sportsman.

Formerly on the drowned lands of Orange county, on the meadows of Chatham and Pine Brook, on the Passaic and its tributaries, before the modern system of draining and embank ing, hundreds, nay! thousands of acres were annually covered with shallow water, at the breaking up of winter, and the inun dated flats were literally blackened with all the varieties of Duck which I have heretofore enumerated, affording rare sport to the gunner, and alluring gentlemen from the larger cities to follow them with the canoe ; in a day's paddling of which, among the inundated groves, and over the floated meadows, it was no unusual event, nor regarded in any wise as extraordinary good fortune, to kill a hundred fowl and upward of the different varieties, all of which, however, are alike in one respect, that they are all delicious eating. I have myself been in the habit of considering the Summer Duck as the most delicate and succulent 
food of the inland, as distinguished from the ocean Ducks; but this is, I believe, owing greatly, if not entirely, to its being the best fed of its genus in the regions wherein I have been wont to eat it; for I understand that on the great lakes, and in the Western country generally, the Blue-winged Teal is regarded as its superior in epicurean qualifications.

All that kind of shooting is now at an end in this district of country; and although they still abound on the great lakes, along the Canada frontier, and eastward in the British provinces, the vast extent of those inland seas which they there frequent, renders it impossible, or at least so difficult as to become irksome, to take them, except by lying at ambush on points over which they fly, and on the woody margins of the forest streams and inlets, which they frequent for the purpose of feeding and roosting. In such localities, where streams, debouching into the great lakes, flow through submerged and swampy woodlands, the Ducks of all kinds are wont to fly regularly landward, in large plumps, or small scattered parties, for an hour or two preceding sundown,-and a good shot well concealed in such a place, with a good double-gun, loaded with No. 4 up to $\mathrm{BB}$, as may be the nature of his ground, and the species of his game, will frequently return from a single evening's expedition, loaded with twenty or thirty couple of wild-fowl.

For this sport, however, little or no advice is needed,- a good covert, a heavy gun, and a sufficient charge, are all that can be deemed requisite to success. The sport may, however, be rendered both more rapid and more exciting, by the introduction of the large Water Spaniel, well broken to fetch, to aid as a retriever. Every true sportsman knows how much zest and enjoyment is added to every kind of field sports, by the adaptation to it, and the observation during its continuance, of the instinct and sagacity of trained animals; and that of the water retriever is inferior to none. He must be trained to absolute muteness, and the most implicit obedience; he must never stir from the spot in which he is ordered by a quiet gesture of his master's hand to crouch-close-nay! he must not prick his ear. 
or wag his tail, lest the quick eye of the watchful Duck, or their almost infallible sense of hearing, detect either by sound or sight the impatient movement. Once ordered to recover the dead, or, what is worse, the cripples, neither the cold of the freezing lake, nor the rough billows of the stormy frith, must deter him. In his perfection he is, and needs must be, the most intelligent, and so far as endurance goes, the bravest of dogs ; and so far as the fowler's particular sport unquestionably lacks that variety and excitement, both of incident and pursuit, which gives the great charm to every kind of shooting or hunting, it will certainly be well to add to it the increased pleasure afforded by the use of the retriever.

I used to suppose that the best species of dog for the Upland retriever, is the large Water Spaniel, as, undoubtedly, for seafowl shooting the small, sharpish-eared, St. John's Newfoundland dog is preferable to all other races. In a work which has lately come before me, however, of which I think very highly, I find the following observations, the correctness of which I believe to be indisputable; and I little doubt that the sort of dog here described, would be of general utility to the sportsman. The book to which I allude is "The Moor and the Loch," by Colquhoun, of Luss, who, in the sphere of wild sports, to which he has paid attention, is not, I think, inferior to Col. Hawker, when mounted on his hobby of British sea-fowling.

From this book, while on the present topic, I shall again quote; and, without farther apology or explanation, proceed to extract his views as to the dog most fitting as the Duck-shooter's assistant.

"Next in importance to the gun," says Mr. Colquhoun, " is a proper retriever. The Newfoundland is not quite the thing: first, his black color is against him"-white, of course, is out of the question- "brown is much to be preferred; then, I should wish my dog occasionally to assist me in this inland shooting, by beating rushes, or thick cover, up creeks, where you may often plant yourself in an open situation for a shot, and your dog put up the fowl, which are almost certain to fly down past you. 
If you accustomed a Newfoundland dog to this, he might, from his strength and vivacity, learn the trick of breaking away when you did not wish him. The best and most efficient kind of dog for this work, is a cross between a water-dog and large terrier; the terrier gives him nose, the water dog coolness and stcadiness. I should say, that before you can procure one which, upon trial, may prove worth the great trouble of thoroughly training, you may have to destroy half-a-dozen. You should begin your training when the dog is very young, and if you find out he is not turning out as you wish, seal his fate at once. The dog you want must be as mute as a badger, and cunning as a fox. He must be of a most docile and biddable disposition-the generality of this breed are so. They are also slow and heavy in their movements, and phlegmatic in their temper-great requisites; but when fowl are to be secured, you will find no want either of will or activity, on land or water." Our Highland sportsman then proceeds, in allusion to the subject of a wood-cut illustrating his work, which he states to be the best he ever saw, "he never gives a whimper, if ever so keen, and obeys every signa! I make with my hand. He will watch my motions at a distance, when crawling after wild-fowl, ready to rush forward the moment $I$ have fired; and never in one instance has he spoiled my shot. I may mention a proof of his sagacity. Having a couple of long shots across a pretty broad strean, I stopped a Mallard with each barrel, but both were only wounded. I sent him across for the birds; he attempted at first to bring them both, but one always struggled out of his mouth; he then laid down one, intending to bring the other; but whenever he attempted to cross to me, the bird left fluttered into the water; he immediately returned again, laid down the first on the shore, and recovered the other; the first now fluttered away, but he instantly secured it, and standing over them both, seemed to cogitate for a moment; then, although on any other occasion he never ruffles a feather, he deliberately killed one, brought over the other, and then returned for the dead bird." 
After proceeding to give some further information with respect $t$ () accoutrements, among others of which he expatiates on the absolute necessity of a small pocket telescope as part of the wild-fowl shooter's equipage, he gives an account in extenso of the best method to be adopted for getting within shot of wildfowl, when seen feeding on, or within shot, of the shores of an inland loch or pond. These, as they are of the utmost value and interest in themselves, as there are thousands of localities exactly such as he describes, in every region of the United States, from the rock-girdled, pine-embosomed lakelets of Maine and the Eastern States, to the limestone pools of the Pennsylva nian Alleghanies, to the limpid basins set in the oak openings of Michigan and Illinois, to the gleaming waters that lie unsheltered from the sun's brightest beams in the centre of boundless prairies, all of which, in their proper seasons are absolutely alive with wild-fowl of every description, and as to all of these, my author's views are distinctly and directly applicable-I shall extract without alteration or abridgment; observing only, in addition to what I have already stated, that the species of fowl to which he has reference, are nearly in all respects identical with our own.

"Having now equipped our wild-fowl shooter, we will," he says, "again bring him to the shore. His first object should be to see his game without being seen himself, even if they are at too great a distance to show signs of alarm. To effect this he must creep cautiously forward to the first point that will command a view of the shore for some distance; then, taking out his glass, he must reconnoitre it by inches, noticing every tuft of grass or stone, to which wild-fowl asleep often bear so close a resemblance that, except to a very quick eye, assisted by a glass, the difference is not perceptible. If the loch be well frequented, he will most likely first discover a flock of divers, but must not be in a hurry to pocket his glass, until he has thoroughly inspected the shore, in case some more desirable fowl may be feeding or asleep upon it. I will suppose that he sees some objects that may be wild-fowl. Let him then immevoL. 1. 
diately direct his glass to the very margin of the loch, to see if anything is moving there; should he find it so, he may conclude that it is a flock of either Ducks, ${ }^{*}$ Widgeon, $\dagger$ or Teal; those first perceived resting on the shore, and the others feeding at the water's edge, of course not nearly so conspicuous.t If there is no motion at the margin of the loch, he must keep his glass fixed, and narrowly watch for some time, when, if what arrested his attention be wild-fowl asleep, they will, in all probability, betray themselves by raising a head or flapping a wing.

" He must now take one or two large marks, that he will be sure to know again; and also another, about two or three hundred yards, immediately above, farther inland. Having done this, let him take a very wide circle and come round upon his inland mark. He must now walk as if treading upon glass : the least rustle of a bough, or crack of a piece of rotten wood under his feet, may spoil all, especially if the weather be calm. Having got to about one hundred yards from where he supposes the birds to be, he will tell his retriever to lie down; the dog, if well trained, will at once do so, and never move. His master will then crawl forward, until he gets the advantage of a bush or tuft of reeds, and then raise his head by inches to look through it for his other marks. Having seen them, he has got an idea where the birds are, and will, with the utmost caution,

* When the word "Duck" is used in English works without qualification, the Mallard and Duck known, in this country generally, as the "Green-head," are intended.

†The English Widgeon differs essentially from the American bird, but like it, is rather a shore bird than an inland fowl, though it is often shot up the country.

$\ddagger$ "Duck-shooting on rivers and streams is generally unsatisfactory, there are so many turnings and windings which prevent you from seeing the fowl until they are close at hand, also so many tiny bays and creeks, where they conceal themselves beyond the possibility of detection, until the whirr of their wings and the croak of the Mallard betray their hiding-place. Unless the river be large and broad, even the most expert wild-fowl shooter must expect few heavy sitting shots, and content himself with the greater number being distant flying ones." 
endeavor to catch sight of them. I will suppose him fortunate enough to do so, and that they are perfectly unconscious of his near approach. He must lower his head in the same cautious manner, and look for some refuge at a fair distance from the birds, through which he may fire the deadly sitting shot. After crawling serpent-like to this, he will again raise his head by hair-breadths, and peeping through the bush or tuft, select the greatest number of birds in line; then drawing back a little, in order that his gun may be just clear of the bush for the second barrel, after having fired the first through it, will take sure aim at his selected victims. Should he unfortunately not find an opening to fire through, the only other alternative is by almost imperceptible degrees to raise his gun to the right of the bush, and close to it; but in doing this the birds are much more likely to see him and take wing. Never fire orer the bush, as you are almost certain to be perceived whenever you raise your head; more good shots are lost to an experienced hand by a rapid jerk, not keeping a sufficient watch for stragglers, and over-anxiety to fire, that by any other way. Having succeeded in getting the sitting shot, the fowl, especially if they have not seen from whence it comes, will rise perpendicularly in the air, and you are not unlikely to have a chance of knocking down a couple more with your second barrel; but if they rise wide, you must select the finest old Mallard among them, or whatever suits your fancy. Directly upon hearing the report, your retriever will rush to your assistance, and having secured your cripples, you will re-load, and taking out your glass, reconnoitre again; for though Ducks, Widgeon, \&c., would fly out upon the loch at the report of your gun, yet the diver tribe, ${ }^{*}$ if there are only one or two together, are perhaps more likely to be under water than above when you fire; but more of them anon.

* The divers most common to us are the Buffel-headed Duck, or ButterBall; and the two varieties of Merganser, more commonly known as Sheldrakes--to which fowl, it does not, in truth, offer even a remote resemblance. The true Sheldrake Anas Tadorna, being a perfect Duck, and not a diver. 
"Another invariable rule in crawling upon Ducks is always, if possible, to get to the leeward of them ;* for although I am firmly of opinion that they do not wind you like deer, as some suppose, yet their hearing is most acute. I have seen instances of this that I could hardly otherwise have credited. One day I got within about sixty yards of three Ducks asleep upon the shore; the wind was blowing very strong, direct from me to them, a thick hedge forming my ambuscade. The ground was quite bare beyond this hedge, so I was obliged to take the distant shot through it: in making the attempt, I rustled one of the twigs-up went three heads to the full stretch, but when I had remained quiet for about five minutes, they again placed their bills under their wings; upon a second trial, the slight noise was unfortunately repeated : again the birds raised their heads; but this time they were much longer upon the stretch, and seemed more uneasy. Nothing now remained but to try again; my utmost caution, however, was unavailing, the birds rose like rockets. I never hesitate concealing myself to windward of the spot, where I expect Ducks to pitch, feeling confident that, unless I move, they will not find me out. I have often had them swimming within twenty-five yards of me, when

* "If you have also a bright sun at your back, and in their eyes, your advantage is great; but should the sun and wind favor opposite directions, let the nature of the ground decide your advance.

"I was last winter shooting wild-fowl with a gamekeeper who firmly held the common notion of their keen noses. We saw a flock of about twenty pitched upon a long point, and no possibility of approaching them except directly to windward. "Now, sir," says the keeper, " if you'll stalk these Ducks so as to get a good shot, I'll never care for their noses again!" They had the full benefit of the wind as it blew pretty strong, but there was some soft snow on the ground, which I knew would prevent their hearing; so I took him at his word, killed three with my first barrel, and had they not been intercepted by the trees and bushes, would have knocked down at least one more with my second. The keeper has said ever since that their noses are not worth a straw: iny decided advice, however, is not to stalk wild-fowl to windward, if it can be avoided; for should the snow be at all crisp with frost, or if there are many twigs and bushes to crawl through, their noses become acute enough !!!" 
I was waiting for three or four in line, the wind blowing direct from me to them, without perceiving by any signs their consciousness of an enemy's vicinity.*

"When the weather is very hard, and Ducks are driven to the springy drains, a simple way of getting fair shots, but seldom practised, is, to make your man keep close to the drain, and take your own place fifteen yards from it, and about forty in advance of him. The Ducks will then rise nearly opposite to you. To walk along the drain is not a very good plan, as they will generally rise either out of distance or very long shots: and, if you keep a little way off, they may not rise at all. $\dagger$ When the loch is low, the sportsman may often get a capital shot at Ducks, the first warm sunny days in March, $\ddagger$ as they collect on the grassy places at the margin to feed upon the insects brought into life by the genial heat.

"But to return to our wild-fowl shooter, whom we left glass in hand looking out for divers. He sees a couple plying their vocation fifteen or twenty yards from the shore, about half a quarter of a mile from where he stands. He selects his vantage

* "Perhaps the sportsman may ask what it signifies whether wild-fowl are aware of your approach by hearing or winding? My answer is, that although it is of little consequence when crawling upon Ducks, yet when lying concealed, expecting them to pitch, it is a considerable advantage to know that you will not be detected by their sense of smell; otherwise the best refuge for a shot must often be abandoned for a much worse."

+ This plan will be found to answer admirably in this country, not when the weather is very hard, at which times the drains and small streams are frozen hard, but at all seasons when wild-fowl of any kind are marked down into any brook, stream or water-course whatever. If the stream be very tortuous, the shooter should walk parallel to it, just far enough distant not to strike any of its courses, but keeping as nearly as possible a perfectly direct course. The beater should follow every curve accurately. I have have had sport thus with Woodduck, in many districts of the United States ; and once-the best day's inland fowl-shooting, I ever had-killed sixteen young birds, and two fine Drakes in a single morning.

$\ddagger$ For March we must substitute, as regards American shooting, the corresponding season, according to the latitude. The period he means is the first breaking up of winter, and the commencement of mild weather. 
ground as near as possible, for a last look before commencing his attack. Having gained this, he makes his dog lie down, and peeps cautiously until he sees the birds-waits till they both dive together, then rushing forward whilst they are under water, again conceals himself, expecting their re-appearance. The great difficulty is always to keep in view the exact spot where the birds come up : once lose sight of it, your progress is stopped, and, in recovering your advantage, the birds are almost certain to see you and fly. When within one race of the divers, cock both barrels, and as soon as they together disappear, rush to the nearest point on the shore for a shot. If the day be calm, the rising bubbles will show where they are; you can then clap your gun to your shoulder, ready to fire. Always in such cases, shoot on wing, and be sure to fire well forward: should a diver only be winged, it is useless to tire your retriever in pursuit; but if he is at all struck about the legs also, a good dog should be able to secure him.

"So much for the small Morillon.* The Golden-eyet is a still more artful bird, and requires more caution. If, without seeing an enemy, he is at all alarmed while diving near the shore, he will probably swim out to a considerable distance; reconnoitering all the time, and making a noise something like a single note of the hurdy-gurdy. You may perhaps expect his return, and wait for him; but although he may remain about the same place, making these calls, and apparently careless, he is all the time very suspicious; and I only once or twice, in my whole experience, knew him to return to the spot where he was first discovered. Should he get sight of you, there is no hope, even if he does not take wing, which he most likely will. The little Morillon may return if you think him worth waiting for; but he is so hard and coarse on the table, that it would be paying him too great a compliment. The Golden-eye, on the contrary, is a great delicacy-a sufficient proof, I think, were there no

* The small Morillon is a bird very closely resembling our Buffel-headed Duck, though not identical with it.

t'The Golden-eye of England is the same as our own. Anas Clangula. 
other, that Morillons are not young Golden-eyes, as many suppose. This supposition, I hare little doubt, arises from the color of the female Golden-eye being pretty much like that of the Morillon. The shape, however, is different, and the size of the female Golden-eye nearly equal to that of the male. I have shot them, right and left when diving together, the female being the most wary of the two. The Morillon may be in the same flock, as different kinds of divers often are; but there is not half the caution required to get a shot at him, and, when compared, he is much rounder in shape and one-third smaller in size. It may be said, ' and why should not this be the young of the same species?' I answer, 'that the young males of all the Duck tribe that breed in this country, from the Mallard to the Teal, gain their bright feathers the first moulting, after which the young males are at least equal in size to the females; but my chief reason I have already given, if the Morillon is the young bird, why should he reverse the usual order of things, and be less tender and delicate than his parents?'

"When several are diving together, you must get as near as possible without alarming them; and, selecting a couple who dive at the same moment, hoot away the others, who will be far out of reach before their companions come up. They will probably never miss them until they have taken two or three dives, thus giving you an opportunity of getting the shot; of which you would have had a much worse chance while they were together.

"In recommending this, be it observed, I am supposing the ground of difficult access; when favorable, even a novice should be able to get within a run of any number of fowl, without being seen by the most wary of the flock, and can then make his selection. For my own part, I hardly ever adopt this plan, but where the ground is bare and open, an unpractised wildfowl shooter would stand no chance otherwise.

"When the flock is large, it always puzzles a beginner to ascertain the length of time they are under water, in order to know what time he may safely allow for his last run, which in 
such a case must generally be a long one. The fowl are continually coming up and disappearing again, which confuses him, and unless he knows the depth of the water, the only way to find out how long they are under, is to watch the most marked or detached of the flock, and then choose his devoted pair. If the water is very shallow, those below are sure to perceive the flurry made by their friends at the top, as soon as you commence your last run, and instantly join them in their retreat. In such cases it is always best to try for a distant sitting shot, from the nearest refuge you can safely reach, among as many as you can get in line. But by attempting this, there is always a risk of losing the chance altogether, and it should never be resorted to except under such circumstances, or with Dun-birds, * who keep more close together, and thus present a better opportunity for a heavy sitting shot than any other divers.

"Of all wild-fowl, a flock of Dun-birds is the most agreeable to the sportsman's eye. They are the most stupid $\dagger$ of all the diver race. I have even seen them, after having been driven from their feeding ground, return.in the face of the shooter, who had only lain down without any covering or concealment whatever; they have begun diving again within thirty yards, and of course given him a capital shot. I never wish for assistance in manœuvring any other kind of water-fowl, but these may be herded like sheep; and, if feeding on one side of

* The Dun-bird, or Pochard of England, is the same as our Red-head, Fuligula Ferina, which is with us a sea Duck, only frequenting the bays and estuaries of large rivers ; although, like the Canvass-back, it is found westward far inland, on the upper waters of the Ohio, Mississippi, and Missouri.

+ This agrees well with what we know of the facility with which they are toled, as it is called, by the most simple artifice, even the waving of a handkerchief, into gun-shot, on the waters of the Chesapeake Bay. I do not see but that this hint may be found available in Bay-shooting. I know that Brant Geese may be driven by a man rowing, at such a distance from them as not to alarm them into taking wing, up to the very muzzle of a concealed sportsman's gun. This is, I think, a recently discovered habit of the Brant; but is now regularly acted upon, on the south side of Long Island. On the first opportunity I will certainly try it with Red-heads. 
a bay, you have only to conceal yourself at the other, and send your man round to where they are diving. They will most likely come straight towards you, and, again beginning to feed, will probably every five or ten minutes draw all together with their heads up. Now is your time to fire, if you have the good fortune to be within shot; but should you prefer two birds in the hand to waiting for their knitting together, you may have a capital right and left when they come up from diving: I however, should be loath to lose the opportunity of the sitting shot. " There are many other divers that frequent our lochs, such as the tufted* and scaupt Ducks, \&c., but they may all be approached in the same way as the Golden-eye and the Morillon; none are so shy as the former. $\neq$ Those that feed on fish, such

* The Ring-necked Duck of America. Fuligula Rufitorques.

t The Scaup-duck-in the West, Flocking Fowl-on the Chesapeake, Black-head-commonly Blue-bill, or Broad-bill, Fuligula Marila. All these are properly Sea Ducks; but all are found to the Westward, as in Great Britain, more or less inland.

$\ddagger$ "Last winter I had a good opportunity of contrasting the artful and suspicious nature of the Golden-eye with that of the more confiding Morillon. When shooting wild-fowl on the banks of the Teith, I discovered, with my glass, a Golden-eye feeding at the top of a long creek, and a couple of Morillons at the bottom where it joined the river. As they were at some distance from each other, it was impossible to keep an eye upon both. So, knowing that if the Golden-eye got a glimpse of me, he would not stay to take another, I was obliged to trust to the simplicity of the more social Morillons. I got within a fair distance for my last run, when the Morillons, who had caught a transient glance at my manœuvres, paid the compliment of giving me their undivided attention ; but, as they did not leave the ground, nor show any other sign of alarm, I was congratulating myself that all was safe. The moment, however, that the Golden-eye came up from the dive, he perceived that the Morillons were resting on their oars, and instantly was on his guard. It was most curious to see the cunning and tact of the creature, which I had every advantage for observing, as I was well concealed. He kept cruising about, with outstretched neck, peering first on one side of the creek, then on the other, always selecting the best points of sight to halt, and make his observations. Nor would he recommence his repast until the Morillons had set him the example. And, had I not known his usual precaution of making the first dive or two, after being scared, very short, he might even then have escaped." 
as the Goosander, Speckled Diver, Sheldrake, \&c., require rather different tactics. To get a shot at any of these, you must watch which way they are feeding, and, taking your station somewhat in advance, wait until they pass you; they will not keep you long, as they are very rapid in their movements. Take care that the water is pretty deep where you place yourself, or they may dive at too great a distance from the shore for a shot; but, after all, they are good for nothing but to be stuffed for a collection.

"The only other bird that requires a separate notice is the mighty Hooper,* monarch of the flood. To get a shot at the Wild Swan is the great object of the sportsman's desire: he is not naturally so shy a bird as the Wild-duck, but still his long neck, and acute sense of hearing, render great caution necessary. If, as often happens, he is feeding along the shore, you have only to plant yourself in an advantageous situation a good way a-head, and it will not be long hefore he makes his appearance; but if he is feeding at the mouth of some brook or stream, you must crawl in the same way as when after Wild-ducks. Should you get within a distant shot of a Hooper, and are not close to the water side, instead of firing from where you are, rush down to the edge of the loch, and before the Swan can take wing, you will have gained ten yards upon him. When the thaw begins after very hard weather, they are almost sure to be feeding at the mouths of any mountain burns that run into the loch. Should you see Hoopers feeding greedily, nearly oui of rargo of your gun, in place of taking the random shot, try to prevent their being disturbed, and return at dusk of evening, or grey of morning, when they will most likely have come pretty close to the shore, especially if any little rivulets run into the loch near : this rule applies to most water-fowl. If a Swan be

* This is a different bird from the Swan of the Chesapeake, Cycnus Americanus, though closely cognate. Our bird never, I fancy, betakes himself to lakes, or the like, within the limits of the United States, though he is said to do so in the far West, beyond the Mississippi and Rocky Mountains. 
alarmed by an enemy on shore, his wont is not to fly, but to swim majestically away.

"Widgeon* and Teal are approached in the same way as Wild-ducks, only the Widgeon are less shy than the Ducks, and the Teal than the Widgeon. You may sometimes, in calm weather, see Widgeon in a large flock purring and whistling a couple of hundred yards from the shore; you need give yourself no trouble about them, as they will probably not leave their resting-place until they feed in the evening. Always try to get a heavy shot at Widgeon, which, with a little patience, you may generally accomplish. Teal are usually in small flocks; so that, if you can get two or three in line, you had better fire, for fear of losing the sitting chance altogether. I once killed six at a shot; but, except when they collect in small ponds and drains about the loch-side, so good an opportunity seldom occurs. I have occasionally seen Shovellers on our lochs; but only in the hardest winters. They resemble Wild-ducks in their habits : the only one I ever shot was among a flock of Ducks.

"Good sport need never be expected when the loch is large, as many of the fowl swim up creeks, and among the morasses in shore, where it is difficult even to get a flying shot; while those that remain on the margin of the loch are so concealed by the bushes, \&c., that it is quite impossible to see them. The lower the loch the better; at all events, the shore should be clearly defined. At such times wild-fowl have always favorite haunts tor feeding and resting.

"There is a common saying, that specimens of all the different kinds of water fowl which frequent the loch in winter, present themselves during the harvest moon. This is erroneous; for even the Morillon, earliest of the diver tribe, seldom appears so soon, and the Tufted and Scaup Ducks, Dun-birds, \&c., never

* A different bird, though not unlike our Widgeon, Anas Americana, the Bald-pate. It is worthy of notice, that the Widgeon of the Chesapeake is considered the shyest and most difficult to tole, of all the Ducks which frequent those waters. 
until the winter sets in.* Multitudes of Wild-ducks do como down from the moors, during harvest, to feed upon the comfields on the banks of some of the larger lochs, and, when the stubble becomes bare, return to the moor-lochs until these are frozen over, which again drives them back. This is the only foundation for the vulgar error. A day or two is generally sufficient to freeze over these little lochs, and their occupants then come down to the larger ones, the greater parts of which remain open long after the storm has set in. Now is the time for the wild-fowl shooter : if the ground is covered with snow, so much the better. The fowl are then in groups close to the shore, pinched with cold and hunger, seeking shelter and a scanty morsel. If at the same time it is windy, with drifts of snow, no weather can be more propitious for Ducks, Widgeon, Teal, and all wild-fowl that feed at the margin. When the snow is falling thick and fast, a capital sitting shot may sometimes be obtained, though the ground be so bare as to offer no concealment. In most cases, however, it is best not to take the cover off your gun till the shower moderates a little, as snow is so apt to penetrate, and make it miss fire.

"If the weather be open, the higher the wind the better, as it drives to the shore whatever fowl are upon the loch, although until the frost sets in they will be comparatively few.

"The most auspicious weather for divers is one of those frosty days, accompanied by mist, when the loch is perfectly calm, and looks like a mirror dimmed by one's breath. You may then hear their plash in the water-sometimes even before they call be seen-and, if care is taken to make no rustling among the bushes, when they are above the water, you have every pros-

* These observations on the seasons of these birds in Great Britain, might. perhaps, have been omitted; but I consider the whole of this extract so very able and correct, that, taking into consideration the vast extent and variety of latitude corered by the shooting grounds of America, in some of which the climate closely resembles that of England, I have not been able to prevail on myself to omit it ; as I doubt not there are places at which the cap will bo found to fit, and the hints of consequence to be useful. 
pect of a good chance. The smoothness of the surface and the mist makes each bird appear twice as large as it is, which enables you much more easily to catch sight of them coming up from the dive. The mist is also an excellent shroud, if the ground is open, without a bush or tuft of reeds to hide behind, when the birds are above water.

"The wild-fowl shooter must never forget, that true proof of his skill consists in obtaining sitting shots, and stopping a numbe1 of fowl at one discharge; and, unless with divers, must not think of a flying right and left.

"As an instance of what may be done by patience and caution, I may conclude this paper by mentioning, that the gamekeeper of a relation, having seen a flock of Ducks pitched upon the shore, and no way of getting near them but over a bare field, crawled flat upon his face a distance of three hundred yards, pushing his gun before him, not daring even to raise his head, and at last got within such fair distance, that he stopped four with his first barrel, and one with the other, securing them all. His gun was only a small fowling-piece. I should add that he had been trained to deer-stalking, under his father, from a boy."

It may, perhaps, be thought worthy of remark, that this is the single quotation which I shall offer to my readers from any English author, as regards the mode of beating for, pursuing, or killing any kind of game. When I come to treat of gunnery, the breeds, breaking, diseases, and treatment of dogs, and the like topics, it is on British sporting authors especially, almost exclusively, that I shall rely; but, in fact, the game of America is so different, the places and modes of taking it so much at variance, and the habits of the few animals of chase, which are nearly allied in the two countries, are so completely distinct from those of England, that the precepts of the best English sporting writers are useless here. Of Col. Hawker's great work, above half-which half was very properly rejected by its able American editor-relates to fowl shooting, and fowling 
apparatus, as practiced and adopted on the coast of England, all which would be of no more use to a sportsman here, than a treatise on archery of the fourteenth century to a Kentucky rifleman.

The above extracts are practical, and applicable to any and every country, and cannot fail to be found generally useful.

The only other observations to be made on Upland fow] shooting, relate to the quality of gun most adapted to the sport, and the size of shot, grain of powder, and the like, which are, of course, all more or less different from those used in Upland shooting for ordinary game.

To a person living in a country where this sport can be readily and often pursued, and who is an amateur in it, a gun especially made for the purpose is indispensable. It must be a double-barrel, and as heavy as can conveniently be carried; the more metal, the less recoil, and the greater force of propulsion ; extreme length is utterly useless-nay, detrimental!-for a gun of four feet barrel must either be unmanageably ponderous, or must be so light at the breech as to become top-heavy. All that-is requisite is a gun that will throw from two to three ounces of No. 3 or 4 shot, very strong, and very regularly distributed. For any ordinary purpose, two ounces of shot is sufficient; and in my opinion the gun which will do that as effectively as any that can be made, is one of 12-guage, 36 inches barrel, and 9 to $10 \mathrm{lbs}$. weight. A gun of this kind can be furnished by Mr. Mullin, of Barclay street, New-York, next door to the "Spirit of the Times" office, for a hundred dollars, of excellent quality; and I only give an opinion on which I have acted, and not been disappointed, when I say that I would rather have a gun of his workmanship made to my order, for any price not exceeding one hundred and fifty dollars, than any imported gun at the same rate.

The high qualities of English guns are not to be surpassed, but cannot be furnished by any first-rate maker short of-appurtenances included-£56. This, with 30 per ct. ad valorem duty added, shipping charges, \&c., will amount to a very large price. 
Nevertheless, I say, if any man be disposed to go to the trouble of importing an English gun at all, let him import a first-rate and first price London article. I never saw a Birmingham gun I would have cared to shoot with; and I do not consider that Westley Richards' merits at all equal his reputation. I consider Purdey, Lancaster, and Moore and Gray, the first three makers of the day; and were I offered the gift of a gun, with the choice of the maker, I should name the latter house as my makers.

No. 4 shot I consider quite large enough for any kind of fowl, unless Canada Geese, or Wild Swans; but I would always use a green Eley's cartridge in one barrel. The best powder, beyond all question or comparison, for fowling, and especially sea shooting, is what is called Hawker's Ducking Powder, prepared by Curtis and Harvey, as the diamond grain of the same house is by all odds the quickest, strongest, and cleanest powder in the world. The grain of the ducking powder is extremely coarse-coarser than cannon powder-and very hard; it is not, therefore, liable to become damp or liquefied, when exposed to a saline atmosphere. Notwithstanding the large size of its grain, it is readily ignited even in a small gun, by one of Starkey's central fire waterproof caps. One of these, for an experiment, I kept forty-eight hours in a tumbler full of water, and it exploded quickly and cleanly. There is nothing like them,--but, like all good things, they are dear. For the rest, a person who cares to keep but one gun, will find himself able to do good work with a general shooting piece of 14-guage, 32 inches barrel, and 8 lbs. weight, even at fowl, if he uses No. 4, Eley's wire cartridges. Verbum sap. And so adieu to Upland shooting. 


\section{SPOR T IN G D O GS.}

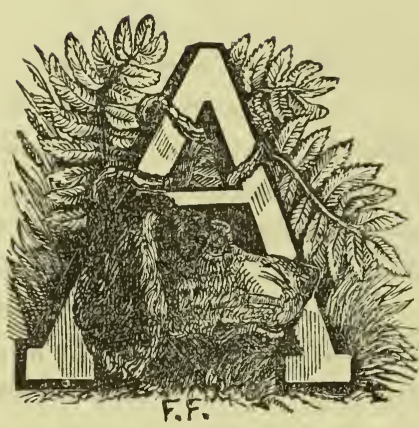

S without the aid of well bred and well broke dogs no game can be either successfully or scientificallly pursued, and as in the management of this noble animal both in the kennel and the field consists, perhaps, the greater part of the true science of woodcraft, no work on field sports can be esteemed in anywise complete, which does not treat of their breeds, characteristics and general treatment; whether in health, in sickness, in the house, or in the field. This portion of my subject, I therefore, now approach, without farther observation than this, that neither a complete history of canine pathology, nor a full treatise on dog-breaking must be looked for within the limits of such a book as this, and that a few general directions and hints only can be afforded on a topic which has itself occupied many volumes, devoted to it entirely by writers of competent talent and experience.

Two of these, more especially, should be found in every sportsman's library, I mean Youatt on the Dog, and Blaine's Canine Pathology. Of the first of these works a handsome edition has been recently published by Messrs. Lea \& Blan- 
chard of Philadelphia, under the editorial supervision of $\mathrm{E}$. J. I.ewis, M. D., of that city, a gentleman who has performed his part with creditable accuracy, diligence and research; and, whose fondness for the animal in question, and his long study of its peculiarities, entitle his observations to respectful attention; although to some of his views, especially in regard to breeding and races, I must enter my dissent. The latter book has never, I believe, been republished in America, but the English edition is not costly, and may be obtained from any considerable bookseller in the United States. With these two guides and text-books in his possession the sportsman will be little at a loss in regard either to the diagnosis or treatment of diseases, which he must perforce attend to personally in this country, as veterinary surgeons are neither numerous nor skilful, generally speaking, even in the larger cities, while in the country districts they are not; and even where they are, canine pathology is little understood or professed by them.

To proceed at once then in medias res, the races of sporting dogs used in upland shooting, are three in number, the Setter, the Puinter and the Spaniel, and of each race several varieties are in use, all being of the division known as sagaces, being distinguished by their qualities of instinct and powers of scenting, in contradistinction to speed or ferocity.

Of these the best known, and most generally used, and 1 must think with justice, as superior in beauty, endurance and aptitude to our climate and style of shooting, is

\section{THE SETTER.}

The origin of this beautiful and admirable species is beyond a doubt, the large land Spaniel improved by judicious breeding to his peculiar size and beauty, and taught, until teaching has become second habit, and the result of training grown into an hereditary instinct, to mark his game by setting or crouching. instead of flushing it on the instant. 
A great deal of absurd nonsense has been written about the breed and race of the Setter, from the mass of which I shall select the following passage for two reasons, first that it reaches the very climax of possible stupidity, and second, that it is from the pen of one who should know better, at least to merit the reputation he has acquired; being no other than the person who has gained very considerable celebrity as the author of "The Sportsman in France," "The Sportsman in Ireland and Scotland," and "The Sportsman in Canada."

After stating that the Setter is his favorite dog in the field, and decidedly the most useful for general shooting in France," Mr. Tolfrey actually proceeds to give the following receipt for making a breed of Setters, forgetful, apparently, that it is very unnecessary to set about making, what nature has already made in perfection to our hand, and quite ignorant, it should seem, that it is impossible to make a pure strain from any combination of crosses. There is no doubt whatever that the true Setter is a pure strain of unmixed Spaniel blood, the only improvement produced in the breed arising from its judicious cultivation, by the selection of the largest, healthiest and handsomest individuals of both sexes from which to rear a progeny, and by the careful development of their qualities, by scientific feeding, exercising, and bringing into condition. The following reccipt may therefore make a useful mongrel, but can no more make a Setter, than crossing a Quagga, a Zebra and a Canadian pony-all varieties of the horse breed-can make a thorough-bred.

"The preliminary step," he says, "is to put a fine bred and unexceptionable Pointer bitch to a noted Foxhound; you will then have laid the foundation of three essential qualities, speed, nose and courage. Docility and sagacity are also requisites, and to obtain them cross the offspring with the small and slender race of Newfoundland dog. The produce will be as near perfection as possible; they will take to the water, retrieve, and for general shooting will be found the very best and most useful animal the sportsman can desire." 
I quote the above as I have said, merely to caution the sportsman against giving the least heed to any such stuff, and to warn him to avoid any crossing or intermixture of breeds as he would the plague. If he prefer the Pointer, let him stick to Pointer, but let it be a Pointer pure. If Setter, let him do the same. Any mixture, even of those two kindred bloods is in nine cases out of ten, disadvantageous, and instead of combining the peculiar excellencies, the produce is very apt to unite the worst qualities of the several strains, superadded to a sullenness and badness of temper, which is in some sort, the characteristic of all mules.

$\mathrm{Mr}$. Lewis is under the impression, as I gather from his comments on Youatt, that it is the fashion in England, to intermix Setter and Pointer blood, by way of improving the former, and that the majority of English Setters has been so intermingled intentionally, with the idea that the qualities of the animal are improved thereby.

This idea is utterly erroneous; for, although doubtless much Setter blood has been thus vitiated, no persons priding themselves on their kennels, or fanciful, not to say scientific, about their breeds of dogs, would admit one of these mongrels into their establishment, much less breed from him. Such an intermixture is regarded as decidedly a taint, as a strain of cock-tail blood in the peligree of a thorough-bred horse. And very many noblemen and gentlemen pay as much attention to their breeding kennels, and their peculiar and private strains of Pointers and Setters, as others do to the breeding and rearing of the race horse.

The Pointer is a made dog, that is to say, he is not of an original or pure breed, traceable to any one variety, nor has he been known to the sporting world for any considerable length of time. The Spaniel is first mentioned, and that in lis improved form as a Setter, i. e. taught to couch, in a NS. work written by the grand huntsman to Edward the Second, so long ago as A. D. 1307, whereas the Pointer was not known in the sixteenth century, and probably has nct existed in his present 
improved form, for much above a hundred years. He was known originally as the Spanish Pointer, and was probably first reared in that country, to which his peculiar capacity for enduring heat and the want of water singularly adapts him.

It appears probable that he is an improved or altered forn of the Foxhound, bred and trained to stand instead of chasing his game, and to repress his cry; and it is generally supposed that this was effected and his present type obtained by crossing the Foxhound with the Spaniel. I cannot say that I believe this to be the case, as I cannot see by what analogy the crossing a feather-sterned dog, such as the Hound, with one entirely rough and silky-haired, like the Spaniel, should result in the production of a race, the characteristic of which is the closest and most satin-like of coats, and the whip-like tail of a rat. I am inclined myself to believe that the original stock is from the Foxhound, and smooth-haired Danish or Pomeranian dog, crossed perhaps again with Spaniel, but so slightly as to show few of its characteristic points. The Pointer being, as I have said, originally a cross-bred dog, sportsmen continued to mix his blood occasioually to obtain different qualities, to a late period, and even now Foxhound blood is occasionally added, in order to give dash and courage. I should not be surprised to find that a cross of the Bull-dog had been introduced, as it was advantageously into the Greyhound by Lord Orford, though I have found no mention of the fact-but the type of the animal is now firmly established, and the finest breed reproduces itself in its finest strain, if purely bred.

The cross breeding, which I have named, has never been allowed with regard to the Setter, however, except by some ignorant or prejudiced keeper, or some person desirous of preserving, by this unnatural union, some qualities of a favorite individual of either strain. In any well-kept kennels a chance litter from a Setter bitch by a Pointer dog, or vice versá, would undoubtedly be condemned to the horse-pond, and with Irish sportsmen, who are very choice of their Setters, a cross even with the English Setter would be regarded as a blemish. 
The Setter is too well known in this country to require a particular description, it may be well, however, to call the attention to some of those points, which peculiarly indicate purity of breed; the first of these is undoubtedly the nature of his coat, which, in the finest and purest strain, is long, sleek and wavy, but not curly, even upon the crest and ears-a tendency to curl indicating an admiyture of the Water Spaniel-it should be as soft, and almost as fine and glossy as floss silk, and on his stern and along the back of his legs should expand into a fringe known technically as the feathering, often of many inches in extent. The head should be broad between the eyes, with a high bony process or ridge at the linder extremity of the skull, between the ears, which is by many sportsmen thought to indicate the degree of the animal's olfactory powers. There should be rather a deep indenture between the eyes; the nose should be long rather than broad, and somewhat tapering, with soft, moist, well-expanded nostrils, and above all things, a black nose and palate, with a full, liquid, dark and singularly expressive eye. The best breed is not very tall or bulky, and the great, heavy-shouldered, coarse, square-headed, club-tailed, fleecy brutes which are generally called Setters, in this country, are probably the result of some such cross as that recommended by Mr. Tolfrey, on the original Setter stock.

The best and most useful dog is of medium height, very deepchested and high-withered, what we should call in a horse, well coupled, or closely ribbed up, and rery strong and broad across the loins. The legs should be straight, and the longer to the knee and hock joints, and the shorter thence to the pasterns the better. The feet should be hard, round, and cat-like, and well provided with ball and toe tufts, which are of great efficacy in protecting the feet from becoming sore, either from wet and ice, or from liard, stony, or stubby ground. Their action, when in movement, is very lithe and graceful, the stern is carried high, and constantly feathered, and it is a good sign if the head is likewise carried high, and if the dog snuff the air when scenting his game, rather than "stoop his nose to the ground, and 
puzzle for his scent, which habit is often the result of a dificiency in his olfactory power.

In my opinion, the Setter is infinitely preferable to the Pointer everywhere, unless in dry, barren plains, where water is not to he had; as in such places the Pointer can hunt well on an allowance of fluid, on which a Setter could not exist. The Pointer is more docile, it is true, and has, perhaps, a finer nose, though I think his extreme caution, rather than superior scenting qualities, has led to the idea of his superiority in this respect. These qualities are, however, counterbalanced by so many other points of superiority on the part of the Setter, that I must decidedly give him the palm over his rival, and especially for this country, in which I am perfectly satisfied that one brace of Setters will do as much work, and that work more satisfactorily, than two brace of Pointers, hunted steadily through the season, week in and week out. Individual Pointers may be, and have been, of rare excellence, but as a race they cannot compete with the Setter. For a mere tyro, who does not know how to control his dogs, or for one who lives in a city, and takes his dog out five or six times in a year only, a Pointer is undoubtedly preferable-for, without work, a Setter is apt to be headstrong and wild-but for the every-day shot, the all-daylong shot, the rough-and-tumble, eager, scientific, keen sportsman, rely upon it the Setter is the dog.

Of the Setter, there are three principal varie ies.

The English Setter, which is the animal commonly in use in this country, too well known to need peculiar description, of which the points described above are the principal characteristics. He is found of all colors-black, black and white, black and tan, pure white, liver, liver and white, orange or red, and yellow and white spotted; and of all these colors he is found good; indeed, as of the horse, it may be said, that a good dog cannot be of a bad color. Nevertheless, I am apt to think that liver color is apt to indicate a predominance of Pointer, or Water Spaniel blood, though take him altogether, the best dog I ever owned was liver and white, and so curly about the head that I 
sometimes suspected a Spaniel cross. A chocolate-colored nose [ look upon as very suspicious, and a flesh-colored, or white nose, I think indicative of softness of constitution.

The Irisi Setter is either pure red, or red and white, or yellow and white spotted. His nose, lips, and palate, are invariably black. His coat is somewhat more wiry, and his frame more bony and muscular than the English dog. He is the har diest and most dauntless of the race, and, though apt to be somewhat unmanageable and headstrong, if he is sufficiently worked, and managed with a tight hand, these faults can be kept down, while his indomitable pluck, his rapidity, his perseverance, and his dash, render him, in my opinion, for the real hard-working sportsman, preferable to his English brother.

The Scotci and Welsh Setrers are in no respect distinct varieties, and only differ from the English, as being inferior in purity of blood. The Irish dog is undoubtedly the original type of the Setter in Great Britain.

The Russian Setter is, however, clearly a distinct variety; and it is a little remarkable that this race has never been described in any American work, and that Mr. Youatt, and his editor, Dr. Lewis, seem to be alike unaware of its existence.

It is rather taller than the English dog, and is very muscular and bony. The head is very much shorter and rounder than that of any other Setter, and is covered with such a fleece of coarse woolly hair, that unless it is clipped away from the brows, the animal can scarcely see. The whole body is covered by a coat of long, thick, woolly fleece, hanging in elf-locks knotted together, of many inches in length, as curly, though six times as long, as those of the Water Poodle. Its olfactory powers are of the very highest order, its docility and sagacity unequalled, and its courage in facing briars or water, its endurance of cold and fatigue, are such as to entitle it, in my opinion, to the first place of the whole race. It makes an admirable retriever, and would, I think, suit this country beyond any dog with which I am acquainted, though I have never seen one in America. It is less handsome than the English and Irish breeds, but its qua- 
lities are first-rate. They are more common in the North than in the South of England, and are much used on the moors. The Duke of Devonshire had, when I was in England, and I believe keeps to this day, this fine variety in its purity ; and in my boyhood, my father, the late Dean of Manchester, had some excelJent dogs of the Russian breed, one of which, Charon, was the best $\mathrm{dog}$, far or near, over which I ever have drawn a trigger.

As the excellence of the Setter or Pointer is a mooted question, and one of great utility and importance to the sportsman, I am not willing to rely solely on my own judgment therein, and have, on this account, extracted from the American edition of Youat, Dr. Lewis' opinion of the merits of the SeTter, compared with those of the Pointer.

"It cannot for a moment be doubted," he says, "that the Setter has superior advantages to the Pointer, for hunting over our uncleared country, although the Pointer has many qualities that recommend him to the sportsman, that the Setter does not possess. In the first place, the extreme hardiness and swiftness of foot, natural to the Setter, enables him to get over much more ground than the Pointer, in the same space of time. Their feet also, being more hard and firm, are not so liable to become sore from contact with our frozen ground. The ball-pads being well protected by the Spaniel toe-tufts, are less likely to be wounded by the thorns and burs with which our woods are crowded during the winter season. His natural enthusiasm for hunting, coupled with his superior physical powers, enables him to stand much more work than the Pointer, and oftentimes he appears quite fiesh upon a long-continued hunt, when the other will be found drooping and inattentive.

"The long, thick fur of the Setter, enables him to wend his way through briary thickets without injury to hirnself, when a similar attempt on the part of a Pointer, would result in his ears, tail and body being lacerated and streaming with blood.

"On the other hand, the Pointer is superior tn the Setter in retainirg his acquired powers for hunting, and not being naturally enthusiastic in pursuit of game, he is more easily broken and kept in proper subjection. 
"The Setter frequently requires a partial rebreaking at the commencement of each season, in his younger days, owing to the natural eagerness with which he resumes the sport. The necessity of this, however, diminishes with age, as the character and habits of the dog become more settled, and then we may take them into the field, with a perfect assurance of their behaving quite as well on the first hunt of the season, as the siaunchest Pointer would.

" The extreme caution, and mechanical powers of the Pointer in the field, is a barrier to his flushing the birds, as is often witnessed in the precipitate running of the Setter, who winds the game, and frequently overruns it, in his great anxiety to come up with it. But this occasional fault on the part of the Setter, may be counterbalanced by the larger quantity of game that he usually finds in a day's hunt, owing to his enthusiasm and swiftness of foot. Setters require much more water while hunting than the Pointer, owing to their thick covering of fur, encouraging a greater amount of insensible perspiration to fly off than the thin and short dress of the Pointer. Consequently they are better calculated to hunt in the coldest seasons than early in our falls, which are frequently quite dry and warm.

"A striking instance of this fact came under our own immediate observation this fall, when shooting in a range of country thinly settled, and uncommonly dry. The day being warm, and the birds scarce, the dogs suffered greatly from thirst, insomuch that a very fine Setter, of uncommon bottom, was forced to give up entirely, completely prostrated, foaming at the mouth in the most alarming manner, breathing heavily, and vomiting from time to time a thick frothy mucus.

" His prostration of both muscular and nervous powers was so great, that he could neither smell nor take the slightest notice of a bird, although placed at his nose. He could barely manage to drag one leg after the other, stopping to rest every few moments, and we were fearful that we should be obliged to shoulder and carry him to a farm-house, a considerable distance off. However, he succeeded, with much difficulty, in reaching the 
well, where he greedily drank several pints of water, administered to him with caution.

"He recovered almost immediately, gave me a look of thanks, and was off to the fields in a few moments, where he soon found a fine covey of birds.

"The Pointer, his associate in the day's work, and a much less hardy dog, stood the hunt remarkably well, and seemed to suffer little or no inconvenience from the want of water. The Setter has natural claims upon the sportsman and man generally, in his affectionate disposition, and attachment to his master, and the many winning manners he exhibits towards those by whom he is caressed.

"The Pointer displays but little fondness for those by whom he is surrounded, and hunts equally as well for a stranger as his master."

In this testimony in behalf of the Setter, on the part of an American gentleman, of scientific, no less than sportsmanlike attainments, I shall add the following quotation from "Craven's Recreations in Shooting," a very clever English work-in which, by the way, I find myself quoted, without credit, as an American sportsman, concerning our field sports-in which the question is fully debated, and the excellence of the Russian Setter upheld by competent authority.

"Having now disposed," says Craven, "of that which by a slight license, may be termed the poetry of shooting, before entering upon its mere household stuff, allusion comes in aptly to its intellectual agents. Although as a principle, we have recommended the use of the Pointer in especial to the young disciple of the trigger, the first place, among shooting dogs, must be awarded to the Setter. In style and dash of ranging, in courage, and capacity of covering ground; in beauty of form, and grace of attitude; in variety of color, and elegance of clothing, no animal of his species will at all bear comparison with him. As the respective merits of the Pointer and the Setter, however, have long been a mooted question among sportsmen, 
we have much pleasure in laying before the reader the opinion on this subject of one of the most experienced authorities in England. We speak of Mr. Lang, the well-known gunmaker of the Haymarket, to whom we are indebted for the subjoined letter to that interesting inquiry :-

" "Having had considerable experience in breeding from some of the first kennels in England, Ireland, and Scotland-amongst them those of the late Duke of Gordon, Captain Ross, Mr. Osbaldeston, and other celebrated sportsmen; and having also spent many years, and much money, in the endeavor to produce a superior description of Pointers and Setters, an account of my progress may be useful. I begin with my opinions concerning Pointers, by stating where I consider them superior, and where inferior, to Setters.

" Pointers are better for Partridge* shooting, as they are milder in disposition, more tractable, and closer rangers; the latter a property of all others the most desirable, if you want to kill birds after the first fortnight in the season. They want also less water than Setters, who often suffer much in hot weather, in districts where it is not to be found. True, Pointers require more walking to, to beat their ground properly; but I am persuaded, that if, instead of racing through the middle of a field, as though they were walking for a wager, and thus giving their dogs no earthly chance, young sportsmen were to go slower than they generally do, they would do more justice to themselves, their dogs, and their preserves. Few Pointers can stand work on the moors-where the cream of all shooting is to be had-unless they have been bred, or have been regularly worked on them. I know many gentlemen who greatly prefer them, when so bred, to Setters; but Scotch Pointers are not so highly

* It must be remembered that this quotation is from an English book, and that the English Partridge is the bird spoken of above, there being no Partridge in America. The argument held above, would be perfectly applicable to Quail shooting, were Quail only found in the open, but as they betake themselves, as soon as flushed, to the densest covert, the Setter is here, more than anywhere, in the ascendant. 
bred as south-country dogs, and therefore more calculated for rough work. Many are crossed with the Foxhound, which gives them speed and courage as well as hardness of foot; but the produce of the first cross is generally too high-mettled to be managed with ease, being difficult to break from running Hares, or to down-charge; and, for the most part, very hard-mouthed. You may reckon on six days out of every twelve being rainy in the Highlands; the wet, and injuries from burnt heather, $\& c$, cause the Pointer soon to become foot-sore, particularly between the toes, as he has no hair to protect his feet, like the Setter. High-bred Pointers are also delicate in their appetites, and will not eat the Scotch meal at first. Gentlemen should have plenty of greaves sent to their shooting quarters to mix with it, as meat can seldom be had in the remote Grouse countries. They should give orders that their dogs should be fed immediately on their return from the hills, and their feet carefully washed with salt and water : indeed, if gentlemen saw to those things themselves, they would find their account in it, observing that such dogs as would not feed well were never taken out the following day. 'A stitch in time saves nine,' is a good wholesome maxim.

"“ 'I now proceed to speak of the Setter. The Irish Setters are very beautiful both in and out of the field; but so hot-headed, that unless always at work, and kept under very strict discipline, they constantly spoil sport for the first hour, frequently the best in the whole day. I have shot to many, and found them all pretty much alike. I had one, the history of whose bad and good qualities would fill half-a-dozen pages. As long as I kept him to regular hard work, a better never entered a field: I refused forty guineas for him, and shot him a month afterwards for his bad deeds. I bred from him, out of an English Setter bitch, and some of the produce turned out very good; one of them I shot to myself for eight seasons : my reasons for parting with him I will presently explain. Unless to throw more dash into my kennel, I should never be tempted again to become master of an Irish Setter. Frequently, Partridges are driven 
into gorse or low cover, in the midale of the day, which few Pointers will face. I know it is not the fashion to shoot to dogs in cover; but most true sportsmen prefer shooting five brace of pheasants to Setters or mute Spaniels, to fifty brace to beaters. In the latter case you stand sometimes an hour together without getting a shot; and then they rise a dozen at a time, like barndoor fowls, and as many are killed in a few hours as would serve for weeks of fair shooting.

" 'In the season of 1839 I was asked for a week's shooting into Somersetshire, by an old friend, whose science in everything connected with shooting is first-rate. Then, for the first time for many years, I had my dogs, English Setters, beaten hollow. His breed was from pure Russian Setters, crossed by an English Setter dog, which some years ago made a sensation in the sporting world, from his extraordinary performances; he belonged to the late Joseph Manton, and had been sold for a hundred guineas. Although I could not but remark the excellence of my friend's dogs, yet it struck me, as I had shot over my own old favorite Setter-who had himself beat many good ones, and never before been beaten-for eight years, that his nose could not have been right, for the Russians got three points to his one. I therefore resolved to try some others against them the next season; and having heard a gentleman, well known as an excellent judge, speak of a brace of extraordinary dogs he had seen in the neighborhood of his Yorkshire moors, with his recommendation I purchased them. I shot to them in August 1840, and their beauty and style of performance were spoken of in terms of praise by a correspondent to a sporting paper. In September I took them into Somersetshire, fully anticipating that I should give the Russians the go-by; but I was again disappointed. I found, from the wide ranging of my dogs, and the noise consequent upon their going so fast through stubbles and turnips-particularly in the middle of the day, when the sun was powerful, and there was but little scent-that they constantly put up their birds out of distance; or, if they did get a point, that the game would rarely lie till we could get 
to it. 'The Russians, on the contrary, being much closor rangers, quartering their ground steadily-heads and tails upand possessing perfection of nose, in extreme heat, wet, or cold, enabled us to bag double the head of game that mine did. Nor did they lose one solitary wounded bird; whereas, with my own dogs, I lost six brace the first two days' Partridge shooting, the most of them in standing corn.

" "My old friend and patron, having met with a severe accident while hunting, determined to go to Scotland for the next three years. Seeing that my dogs were well calculated for Grouse shooting, as they had been broken and shot to on the moors, and being aware of my anxiety to possess the breed of his Russians, he very kindly offered to exchange them for mine, with a promise I would preserve a brace of Russian puppies for him. Although I had refused fifty guineas for my brace, I most gladly closed with his offer. Since then I have hunted them in company with several dogs of high character, but nothing that I have yet seen could equal them. If not taken out for six months, they are perfectly steady, which is a quality rarely to be met with. Every sportsman must know, that the fewer dogs he can do his work with properly, the better; for if they are in condition, they cannot be too frequently hunted; and their tempers, style of working, \&c., become more familiar to him. On this the whole comfort of shooting depends. Upon these grounds I contend that, for all kinds of shooting therefore there is nothing equal to the Russian, or half-bred Russian Setter, in nose, sagacity, and every other qualification that a dog ought to possess. It may appear an exaggeration, but it is my opinion, in which I am supported by many of the first sportsmen in England, that there is not one keeper in fifty that knows how to manage and break a dog efficiently. It is a common practice for keepers to take their dogs out for an hour or two, twice or thrice a week, morning or evening, just before the commencement of the season-what would be thought of training a horse in that way, for a race over the flat, or a steeple-chase? Hard and constant work is as necessary for a dog, 
that has to hunt from morning to night, and frequently for several successive גауз, as for a race-horse. He should be taken out two or three hours daily, in the middle of the day, to use him to the heat, for three or four weeks before the season begins; and let me observe in conclusion; that if his master were to adopt a similar course, he would have good cause to rejoice in the precaution before the end of his first week's shooting.'

"Another gentleman, a large breeder of sporting dogs, thus answered our queries as to the kind of animal best suited to the general purpose of shooting :-

" ' I have tried all sorts, and, at last, fixed upon a well-bred Setter as the most useful. I say well-bred, for not many of the dogs with feathered sterns, which one sees now-a-days, are worthy the name of Setter. Pointer fanciers object to Setters on account of their requiring more water; but there are generally sufficient springs and peat-holes on the moors for them; and, even in the early part of September, a horse-pond or ditch is to be met with often enough. For cover, or Snipe-shooting, the Setter is far superior, facing the thorns in the cover, and the wet in the bogs, without coming to heel, shivering like a pig in the ague. I have always found, too, that Setters, when well broke, are finer tempered, and not so easily cowed as Pointers. Should they get an unlucky undeserved kick, Don, the Setter, wags his tail, and forgets it much sooner than Carlo, the Pointer. My shooting lying near the moors, takes in every description of country, and I always find that, after a good rough day, the Setter will out-tire the Pointer, though, perhaps, not start quite so fiash in the morning.

" 'I always teach one, at least, of my dogs to bring his game, which saves a world of trouble, both in and out of cover, but never allow him to stir for the bird until after loading. Should any of these remarks prove of service, I shall feel most happy in having assisted a brother sportsman." "

To this I will only add, that I have both seen and owned Setters, which on the first day of the season were as steady and 
as perfectly under command, as on the last; that I have seen them tried, day in and day out, for weeks together, with the most admirable imported Pointers, and that they proved always equal to them; in late Snipe-shooting, when the water is cold and skimmed with ice, or in autumn shooting in thorny and briary covert, they beat them out of sight.

I may mention here a brace which I possessed, and over which I shot eight seasons, never allowing any person to hunt them on a single occasion after their leaving the breaker's hands, except myself, and keeping them at steady work. One was a liver and white English dog, broke by Mr. Sandford, of NewJersey, whom I have mentioned before; the other a red Irish Setter, with a white ring and four white stockings, broke by Dilke. They were both undeniable dogs, but the liver and white was the best retriever I ever saw. The test of their excellence is in the fact that in 1836, the late Mr. Peter G. Barker, of New-York offered me, and I refused, eight hundred dollars for the brace. They had cost me two hundred, and I had shot over them four seasons afterward, when the price was bid. I have only farther to say that I never regretted the refusal, as I never saw in all respects a brace of dogs so perfect.

I shall now proceed to the Pointer.

\section{THE POIN TER.}

It is conceded that this animal is the offspring of the two ancient races known as sagaces, or intelligent, and pugnaces or bellicosi, or warlike, and I am inclined to think, myself, that his share of the latter blood, is even greater than is generally imagined. His intelligence, except so far as indicated by his power of scenting his game, is of rather a low order, and though docile and easily commanded, he is not generally sagacious, or affectionate. Neither his temper nor other qualities, except in the field, greatly recommend him; but for the steady pursuit of 
his game in the open plain, his great caution in not overrunning it, his great capacities of enduring heat and thirst, and his retentive memory of what he has been taught, unqualified by any headstrong or impetuous dash, render him, for the pursuit of some species of animals and for some localities, unrivalled. Of the latter there are few in this country. The sandy Grouse barrens of Long Island, Martha's Vineyard and the New-Jersey Pine-grounds, while there were Grouse on them, were well adapted to the display of his peculiar and characteristic excellencies. The Grouse mountains of Pennsylvania are so rocky and so much beset with stubs that his bare feet, unless protected with buckskin boots, through which the claws must be suffered to protrude, will not enable him to bear the wear and tear of daily work. Some of the western praries, which are $d r y$ and deficient of water, are well suited for him, as in Wisconsin and parts of Michigan; and there, he is prized, and deservedly.

Of this animal there are two breeds, separate and conspicuous, of which all the others are varieties, and none of the latter sufficiently peculiar or different either in appearance or qualifications to merit any especial description or notice.

These two breeds are the Old Spanish Pointer, which is the origin and type of the race, and the improved, or Evglish Pointer. Of the former, the Portuguese, and of the latter, the French Pointer, are coarser and inferior varieties,-all the points attributed to the last-named dog as characteristic, namely, large head, pendent ears, and thick tail, being common to every coarse, ill-bred English dog.

“The Spanish Pointer," says Mr. Youat,, "originally a native of Spain, was once considered to be a valuable dog. $\mathrm{He}$ stood higher on his legs, but was too large and heavy in his limbs, and had widely spread ugly feet, exposing him to frequent lameness. His muzzle and head were large, corresponding with the acuteness of his smell. His ears were large and pendent, and his body ill-formed. He was naturally an ill-tempered dog, growling at the hand that would caress him, even vol. I. 
although it were his master's. He stood steadily to his birảs but it was difficult to break him of chasing the Hare. He was deficient in speed. His redeeming quality was his excellent scent, unequalled in any other kind of dog.

"To convince our readers of the value of this particular breed, we may mention the very singular sale of Col. Thornton's dog Dash, who was purchased by Sir Richard Symons for one hundred and sixty pounds' worth of Champagne and Burgundy, a hogshead of Claret, and an elegant gun and another Pointer, with a stipulation that if any accident befell the dog, he was to be returned to his former owner for fifty guineas. Dash unfortunately broke his leg, and in accordance with the agreement of sale, was returned to the Colonel, who considered him a fortunate acquisition as a stallion to breed from. See Blain or Daniel."

This animal, which was once considered very valuable, is now entirely superseded by the improved, or English dogs. He was often what is vulgarly called double-nosed, having a deep furrow between the nostrils; and to this peculiarity, I have heard the excellence of their scenting powers attributed, of course absurdly. Mr. Youatt, on the contrary, I am surprised to see, attributes the deficiency of the same powers, in a certain French breed, having the like deformity, to the same cause. I quite agree with Dr. Lewis, in regarding any such reason, whether for good or evil qualities, as wholly visionary.

Ugliness, want of speed, and ill temper, are causes which have banished the Spanish Pointer from the kennel of the true sportsman. More of the blood is to be found in the Pointer commonly used in this country, than in the English breed, the points and characteristics of which are well laid down as follows, by Dr. Lewis.

“The English Pointer will now claim more particularly our attention. It is quite useless to go into a general description of an animal of whom we have already said much, and with whom we are all familiar; but we will endeavor to mention the most striking points of the species, which marks can be referred to as guides in the purchase of a dog. 
"It is a difficult matter to put on paper, in a manner satisfactory either to the reader or writer, the peculiarities of any animal, whereby he may judged pure or mixed. However, there are, generally, some few points in each species, that can be selected as proofs of their genuineness and ability to perform certain actions peculiar to the race.

"But, after all, more reliance must be placed upon the good faith of the seller, or the previous knowledge of the strain from which the purchaser selects-and what is better than either, from actual observation in the field; all of which precautions may, nevertheless, prove abortive, and our dog be worthless.

"As regards the size of the English Pointer, we may say, that he averages in length about three feet, from the tip of the muzzle to the base of the tail, and from twenty-t wo to twentysix inches high. His head not bulky, nor too narrow, the frontal sinuses largely developed.

"The muzzle long, and rather tapering, the nostrils large and well open, the ear slightly erect, not over long, and the tip triangular; if too pendent, large and rounded at the tip, there is too much of the hound present. The eyes lively, but not too prominent; the neck rather long, and not over thick, the chest broad, the limbs large and muscular; the paws strong, hard, and wide. The body and loins thin, rather than bulky, the hind quarters broad, and the limbs in the same proportion with the fore members ; the tail long and tapering."

To this there is very little to be added, except that the higher the breed, the shorter, the sleeker, and the more satiny the skin, and the thinner the ear. Any tendency to long hair about the stern or legs, hints loudly at a Setter cross, which improves neither the temper nor the qualities of the dog.

Like Setters, Pointers are of all colors, and I know not that any color has the preference; but as in the Setter I should distrust liver color, which I regard as properly a Pointer color, so in the Pointer I look with susp.cion on red or yellow, that being a Setter or Spaniel tint. There is a very pure and high strain of Pointers, principally white, with liver-colored ears and faces, 
having a light tan spot over each eye, and a tan shadowing round the muzzle, and a few liver spots on the body. No tint is preferable to this. Black and tan is an undeniable, though uncommon color for the Pointer, coming probably from Foxhound blood; and pure black dogs are frequent and good. I dislike a black and white spotted Pointer, it has a currish look, to say the least of it.

The more highly bred any animal is, the better he will be, I believe, in all respects. The Pointer's skin becomes infinitely tenderer, and his whole frame more delicate and finedrawn, by high breeding; but so much does he gain thereby, in pluck and courage, that I have seen pure-blooded dogs of this strain tearing their way through cat-briar brakes, literally bleeding at every pore, and whimpering with pain, while great, coarse-bred, hairy brutes, of six times their apparent power of frame, and capacities of endurance, slunk away like curs, as they were, unable to face the thorns.

In every animal, from the man, in whom I believe it tells the most, down to the bullock and the Berkshire hog, I am an implicit believer in the efficacy of blood and breeding to develop all qualities, especially courage to do, and courage to bear-as well as to produce the highest and most delicate nervous organization; and I would as willingly have a cur in my shooting lennel, as a mule in my racing stable, if I had one.

I will now proceed to notice briefly, as becomes the scantiness of his use in this country,

\section{THE COCKING SPANIEL.}

This beautiful, intelligent, and useful dog, which, like the Pointer, is, as his name indicates, probably of Spanish origin, is very little known or used in this country, except as a pet and plaything for ladies; and yet there is no country in the world for which, from the great prevalence of woodland over open 
shooting, the great thickness and severity of the covert, and the peculiar species of game, it would be more useful. There are many varieties of this beautiful, active, and industrious little dog, but the best and most adapted for this country is the large Cocking Spaniel, or Springer, which is found in the greatest perfection in Sussex.

This dog, which is probably the original stock of the Setter, cannot be better described than as resembling a Setter, in the same degree as a punchy, powerful, short-legged pony, resembles a well-bred horse. It is very strong and bony for its size, and has great industry, indefatigable spirit, and indomitable courage-nay! its faults partake of these latter qualities, as it is wont to be rash, impetuous, and headstrong. One of the greatest drawbacks to its excellence in England, would not exist in this country; I mean its propensity to chase Hares, which abound in many preserves there to such a degree, that they are bouncing up at every step, and the Spaniels are yelping and yaffing after them all the time. Here the Hare is comparatively a rare animal, and in this respect the temptation of the Spaniel to wildness, would be very greatly diminished in the United States, or in Canada.

The head of the Spaniel, and especially the nose, is proportionably much shorter than that of the Setter, the frontal sinuses more fully developed, the eye larger and more prominent, the ears much longer and more curly, some so long that they literally seem as if they were intended "to sweep away the morning dew."

Their coats are altogether longer, and more curly, the tails not merely feathered, but bushy, and the legs thickly fringed, even to the toes.

These dogs are of all colors, but I prefer the Blenheim color, rich orange and white, with a full moist eye, and coal-black nose and palate.

They require great steadiness, and constant attention, both in the breaking, and the hunting when broken; but firmness, coupled with general mildness, and constancy of temper, with occa- 
sional severity, will easily prevail, and render them nearly per fect.

As they flush their game immediately, without standing or crouching, it is absolutely necessary that they should be under perfect command; they must never be above ten or fifteen paces distant from the gun, and they must be trained, until it has become their second nature and instinct, to slacken their pace, instead of increasing it, when they strike the trail of game, which the sportsman will learn by their yelp, or, if they be of the mute kind, by the redoubled feathering and flourishing of his bushy tail, and by an occasional low, impatient whimper.

This, and to drop to shot, the instant the gun is discharged, is all they have necessarily to learn; although it is a great addition to their worth, if they are broke to retrieve their game, when ordered to go on, after having dropped to "charge." This dropping to charge, of infinite importance with all dogs, is even more important with the Springer, or Cocking Spanier, than with the Pointer, or Setter; for, whereas the latter are taught both by their instinct and their breaking, to stand or set their game, there is some chance that, if they do break in after shot, they will still point anything on which they may chance to blunder, while the Spaniel being broke to flush, if he stir at all, will indubitably run up everything that crosses his path.

For summer or autumn Cock shooting, for Quail shooting in heavy covert, and for Ruffed Grouse shooting, I am satisfied that these little beauties would be 'invaluable in this country; and that in many districts twice as many head of game might be killed over them, in the same space of time, as over any other kind of dog.

I have often wondered at the neglect of this variety by sportsmen of this country, never having met but three gentlemen, two in the States and one in Canada, who used them. I hope to succeed in importing a brace of highly-bred, and well-broke Springers, of the large breed, this autumn, and to establish the breed. Should I be fortunate in my endeavors, it will be a source of much pleasure to me to accommodate sportsinen de- 
sirous of trying the experiment with some of the progeny, and with my best advice and instructions as to their management and use.

Having thus disposed of the three species of dog used in Upland shooting, I shall proceed shortly to lay down a few plain and general rules, for their treatment in the kennel and the field, their condition, breaking, and some of their more ordinary and dangerous diseases, and then pass onward to fowl shooting . on the shores of the Atlantic.

\section{KEN NEL MANAGEMENT.}

The first point in kennel management is the kennel itself, and, for a person keeping several dogs, the best and most suitable to this country is an enclosure of pickets, sufficiently high to render it impossible for dogs even to attempt to leap over them, surrounding a space of ground the larger the better, as the dogs will then have room enough to run at speed, and to play together, which is undoubtedly conducive to health. This space sliould be gravelled, or strewed with fine sand, and if it could be so contrived as to have a channel of water running through it, that would be a great addition, both to the health and comfort of the dogs.

Along one side or end of this place should be a shed, closed at the back and ends, with a shingle roof, at least ten feet deep, so as to afford a complete shelter from snow, rain, and sunshine. This shed, which should be open in front, must be floored with plank, with a moderate inclination, so as to allow any moisture to drain off readily. The opening should face the south. Along the back of this shed should be ranged a row of ordinary dog-houses of pine plank, one for each dog. These should have no bottoms, that they may be removed, and the boards scoured beneath, from time to time. They should not be less than three feet in length, by two in breadth, and two feet high at the eaves, by three at the ridge. The smaller the aper- 
tuı ine better, provided it is big enough to allow the ingress and egress of the dog. The inside should be whitewashed, and the very best bed that can be devised is fine pine shavings, as it is as soft and warm as any, and the turpentine which it contains is the surest of all antidotes against vermin.

For persons living in towns, not having the command of space, or keeping but a single dog, the movable dog-house, such as I have described, placed on a plank platform, and having a post annexed, to which the dog may be chained, will answer the purpose, though if a dog is kept constantly chained up, he should have regular exercise. If such a kennel as I have mentioned be used, each dog should at first be chained to a staple adjoining his own house, to which he will soon become so perfectly accustomed, that he will never attempt to enter that of his neighbor; and if they are watched at first, and punished if they quarrel, they will live harmoniously enough; provided always, that no bones or scraps of food be ever suffered to remain in the kennel to breed contention, and that none of the fair sexto dogs, as to men, teterrima belli causa-be allowed to be at large among the males, in those seasons when they are most obnoxious to addresses. Setters are much less quarrelsome than Pointers, but steadiness and firmness will keep peace even among the latter.

It is unnecessary to say that the kennel, whether for one or many dogs, cannot be kept too scrupulously clean; as the least collection of dirt not only renders the animal uncomfortable to himself, and offensive to others, but promotes humors, and is a moving cause of some of the worst disorders.

Where it is not found practicable to have a channel of running water through the kennel, each dog should be provided at all times with his own large earthen pan of water, which should be kept continually fresh and renewed; and in each pan there should be at all seasons a piece of bar brimstone, but especially in summer. This, acting as an alterative and gentle purgative, will keep the bowels in good condition, cool the blood, and preserve the softness of the coat. 
It will be found an excellent plan to feed all the dogs, if several, at once, from one long common trough, into which the food should be poured, in regular order, and the dings then called out one by one, by name, from their houses, to which they should previously be compelled io retire, and none suffered to approach until so summoned. The feeder shou'd stand over them, while feeding, with a switch, and the firs: growl, or indication of an attempt to quarrel, should be punished with a smart cut; any voracity, in like manner, can be checked or moderated by a word; and if any dog eat so ravenously, as to get more than his share, he must be quietly, but firmly, called off, and ordered to his own kennel. By this method, order, regularity, and obedience, will be greatly increased in the kennel; and, what is of more importance, the general good humor and good understanding of the dogs will be greatly promoted, so that if, as may often become necessary, as, for instance, in travelling on board steamboats, or in other places where accommodation is difficult and scanty, you should be compelled to feed your dogs out of one vessel, they will eat together cheerfully and agreeably, and lie down to get their rest as good friends, instead of fighting a pitched battle over the plate, and growling at one another all night long, instead of going peaceably to sleep.

Attention to litt e matters of this kind is of great real importance. A fight between a brace of dogs, may deprive the owner of the services of one, or both, for half a dozen consecutive days ; and so destroy the sport of a week, on which he has counted, and for which he has, perhaps, incurred considerable trouble and expense. Even the loss of a night's rest will render dogs peevish, deprive them of their noses, and make them dull and listless during half a day. The subject of feeding is of great importance, and of it I shall treat somewhat at length, after observing that frequent washing and bathing is of exceeding benefit to dogs in fine weather, when they have suitable conveniences for drying themselves. After a swim, or a hard day's shooting in snow, or in marshes, a good wheaten straw bed is the 
best restorative; and that is the only time when I approve of straw for a bed, as it is heating, and has a strong tendency to harbor vermin. To curry a dog, or comb him with a horse's mane comb, and then brush him thoroughly, will be found to contribute to his cleanliness, comfort, and health, in a far higher degree, than the trouble of seeing it done will incommode the sportsman. A little method, and the regular observance of hours, will render all these things easy, and they will soon come to be regarded by the servant as matters of every day occurrence, and as such to be done, and the trouble disregarded.

With regard to feeding, a question on which very much of the condition, and not a little of the olfactory powers of the dog, Mr. Blaine in his great work on Canine Paihology, asks the following question, and proceeds forthwith to answer it.

"What is the best food for dogs? An examination of this animal must end in determining that he is neither wholly carnivorous, nor wholly herbivorous, but of a mixed kind; intended to take in as well vegetable as animal matter, and formed to receive nourishment from either. He is furnished with sharp cutting teeth for tearing flesh, and he has also tolerably broad surfaces on other of his teeth, capable of grinding farinaceous substances : his stomach and intestines likewise hold a middle place between those of the carnivorous and herbivorous tribes. At the same time, both his dental and his digestive organs appear rather more adapted to the mastication and assimilation of animal than vegetable matter; to which also his habits and partialities evidently tend. He is by nature predacious, and intended to live on other animals; the stronger he hunts in troops, the weaker he conquers singly. Yet still it is clear that his organs fit him, when necessary, for receiving nutriment from vegetable matter also, and we likewise see that he voluntarily seeks it, probably as a necessary mixture, to prevent that tendency to putridity, which too great a quantity of animal food begets. It is a received opinion among many sportsmen, that flesh-feeding injures the scent; but it cannot do it naturally: for the fox, one of the caninæ, which is known to be by choice wholly carnivo- 
rous, principally lives by the exquisite sensibility of his olfactory organs. If the eating of flesh really have such an effect on . sporting dogs, it can only do so, when it has been taken in such quantities as to vitiate the secretions of the body; and in this way the pituitary mucous secretion of the nasal sinuses may themselves become somewhat tainted.

" $A$ mixture of animal and vegetable substances is therefore the most proper general food for dogs, and that which best agrees with the analogies of their nature; but the proportions of each are best determined by the exertions of the body."

I do not, I confess, lay any stress whatever on the argument drawn from the natural state of the canince, or from the habits of the fox, since it is too notorious to require comment, that animals in a high state of cultivation, not only acquire new wants as well as new habits, but lose many of their natural qualities and instincts. And I am thoroughly convinced, that the habitual feeding of dogs on flesh has a tendency to injure their powers of scenting; and I believe the reason why it does so, is precisely because it does "vitiate the secretions of the body" generally, and therefore does affect " the nasal sinuses."

I have observed many times, that dogs fed largely, even on perfectly fresh animal food, particularly in a raw state, become intolerably offensive in odor; and when this is the case it is certain that the secretions of the body are vitiated, and probable, moreover, that the health of the animal is in some sort affected likewise.

That flesh is necessary to dogs, I will not, however, deny; and it is my opinion that, during the dead seasons of the year when there is no field work to be done, except exercise, flesh may be given not only without detriment, but with advantage. R.aw meat tends, unquestionably, to give a dog both strength and ferocity; and the latter is so nearly allied to endurance, and what is commonly called pluck, that we can scarcely encourage the one quality, apart from the other's.

I would therefore feed dogs, while getting them into condition, on flesh-and I would not even object to raw horse-flesh for that 
purpose-without stint, save that of their own appetites, having - care to give them a sufficiency of sulphur in their water to keep their bodies open.

Well-fed, nay even rendered fat, upon this strong and hearty food, and worked down into hard flesh and sound condition by constant, and, toward the commencement of season, sharp and fast exercise, Setters or Pointers will have raised such a stock of muscle, and will be so high in courage, that they may safely dispense with all solid animal food during the prevalence of the shooting season.

We have one advantage in this country over the residents of Great Britain, in regard to dog-feeding, that whereas both oat and barley meal are apt to heut the blood of the animal to such a degree as to produce cuticular eruptions and redness, not very dissimilar to mange, we possess in the meal of the maize, or Indian corn, a substance admirably adapted to the food of the dog; which moreover has a tendency to act on him as a slight and gentle alterative.

This I consider to be the perfection of dog-food, and the following is the best way of preparing it.

Take a caldron half full of water, set it over a small furnace, and when boiling cast in a handful of salt : then stir in the meal, keeping the water still boiling, until it has attained the consistency of very thick porridge. Remove it from the fire, and let it cool gradually, running the blade of a knife round the side of the pot, which will prevent its adherence to the metal. When cold, it will have hardened into the consistency of stiff batter pudding, and than this, either alone, or with milk, butter-milk, or pot liquor, no better food can be given to hunting dogs. Observe, however, that the pot liquor of ham, salt-pork, salt-beef, or the like, is objectionable; as is the fat, grease or scraps of such food; the excess of salt having a tendency to produce a very obstinate species of mange.

For a person who keeps several dogs, there is no better mode than to let the butcher regularly supply him with sheep heads, which will cost a mere trifle, at the rate of one for each dog 
every second day. These boiled completely to rags, and the residuum added to the meal, will leave no desideratum in the way of feeding.

It is well to observe that vegetables of almost any kind, as potatoes, carrots, parsnips, and even cabbages, may be added to this mess, and that to the dog's great advantage. The quantity may be gradually increased, beginning with so small a portion that the flavor of the mess shall not be altered, until the dog will eat the regetables almost alone. The best kennel huntsman I ever knew in England, was in the habit of feeding his dogs one day in six, during the hunting season, and twice a week during the rest of the year on vegetables and meal only, without flesh, and I never saw dogs stouter and finer in condition.

Dogs should be supplied freely, if kept chained up in cities, where they cannot procure their natural herbaceous emetic, with the common dog-grass, or queech-grass, triticum repens; and where this cannot be obtained, should occasionally, have an emetic given them, consisting of tartarized antimony-emetic tartar-firm one to three grains, in proportion to the size of the dog. It can be given most readily, mixed with lard or butter into a small ball; or between two slices of meat, when the log is hungry. Common salt, in doses varying from half a small teaspoonful to one and a-half, in proportion to size, may be administered as an emetic; but it is violent in its action, and should therefore be used only when no other can be readily obtained.

When dogs have been very fat previous to the commencement of the shooting season, and strong exercise has been brought into play to reduce and bring them into perfect condition, a few gentle doses of purgative medicine will be of great service to the animal, and will improve all his powers, both of speed, endurance and scent.

"The term condition," says Mr. Blaine, " as applied to dogs is correspondent with the same term as used among horses, and is intended to characterize a healthy external appearance, 
united with a capability, from full wind and perfect vigor, to go through all the exercises required of them. It is, therefore, evident that condition is of material consequence to sportsmen; indeed, it is of infinitely more importance than is generally imagined. What would be thought of that sporting character who should enter his horse for racing without any previous training? and how much chance would he be presumed to have, even to 'save his distance,' without this precaution? Is it not equally reasonable to suppose that Pointers, Setters, Spaniels, and more than all, Greyhounds, ${ }^{*}$ require training; or, in other words to be in full condition also? It is notorious, that Pointers, Setters, and Spaniels, if they are what is termed foul in their coats, never have their scent in perfection. It must be equally evident that, unless they are 'in wind,' they cannot range with speed and durability; and without some previous training, it is impossible they should be so. Those persons, therefore, who expect superior exertion from their dogs in the field, would do well to prepare them by a previous attention to their condition. In Greyhounds, intended either for matches or for simple coursing, it is evident that this is absolutely necessary to insure success. In simple coursing, they are pitted against an animal very nearly equal in speed to themselves, and always in condition by its habits. If, therefore, a dog of acknowledged goodness is beaten by a Hare, especially at the beginning of the season, it is ten to one but the condition of the $\log$ is at fault. It is selfevident that perfect condition must be more than equally important in coursing matches; where a dog has two competitors to beat, the Hare and the other dog.

"The manner of getting dogs into condition is very simple, and

* I was, at first, about to omit that part relating to Greyhounds, as in consequence of there existing no animal in the Eastern States fit for their pursuit, and consequently no field for their powers, they are useless, and only kept as pets. I am, however, so well assured that they must come into use to the Westward, and that the finest sport conceivable might be had with them on the prairies in pursuit of the Deer, the Antelope, and with the large Scotch, wiry breed of the Elk and Wolf also, that I have resolved to retain the whole passage. 
oither consists in reducing the animal from* too full and soft a state to one of firmness and less bulk; or it consists in raising a lean and reduced dog to lustiness, hardness, and vigor. Some sportsmen prefer the one state, and some the other to begin upon. If a dog be fat, his treatment must.be entered on by physic and sufficient exercise, but not by two great a privation of food; and it must be particularly observed, that his doses of physic be mild, but more in number. The exercise should be at first gradual and slow, but long continued; and at last it should be increased to nearly what he will be accustomed to when hunting. If there be the least foulness-i. $e$. if the secretions of the skin are impure-apparent in the habit, besides physic and exercise, alteratives should be given also: these medicines immediately follow the subject of condition. Some sportsmen regularly dress their dogs, before the hunting season, with sulphur, even though no breaking-out appears, and I by no means think the practice a bad one. Others curry or brush their dogs, whether any skin affection appears or not; and, to Greyhounds, it is a very proper means of keeping-up the equilibrium of the circulation, and of promoting muscular elasticity. When a lean dog is to be got into condition, less physic is necessary; but good flesh feeding, plenty of exercise, and a due administration of alteratives, are principally to be resorted to: nevertheless, one or two doses of very mild physic will here also promote the condition and even assist the accumulation of flesh."

\section{ALTERATIVES.}

"Various substances are used as alteratives; as antimonials, and the different preparations of mercury, irin, and tin. The nitrate of potash (nitre,) the supertartrate of potash (cream of tartar,) aloes, salines, \&c., \&c., \&c., are excellent alteratives. Tartarized antimony (emetic tartar) often proves a very useful

* This I conceive to be the true, and by far the easiest mode. It is easy to reduce fat into solid flesh, but very difficult to raise leanness into muscle, an preserve hardness at the same time. 
alterative in the chronic asthmatic cough to which dogs are subject, given as an emetic once or twice a week, in doses of one grain to three. Antimonial powder, or James's powder, may also be given with benefit as an alterative in similar cases. Crude antimony is often found useful in the diseases of the skin; but it is unfortunately very uncertain in its operation: that is, some dogs will bear a considerable quantity, while others cannot even take a small one without violent sickness; the usual dose is from half a scruple to half a drachm. Nitrate of potash (nitre) is a very useful alterative to dogs, for hot itching humors and redness of the skin, in doses of four grains to ten. The supertartrate of potash (cream of tartar) may be so given likewise with benefit in larger doses, in the same cases : all the preparations of mercury, though excellent alteratives, require great caution when frequently repeated, or regularly given; for dogs are easily salivated, and salivation produces very hurtful effects on them."

\section{LAXATIVES AND PURGATIVES.}

"These evacuants are both preventive and curative of disease : they are valuable alteratives, and active immediate agents in acute affections. By opening the bowels, we remove a frequent cause of irritation to the system; and a very considerable source of skin affections also; for whatever is taken up superfluously by the system is apt to find itself an outlet there. We thereby likewise prevent pulmonary congestion, and deposits of fat, which would obstruct the visceral functions. Laxatives are good preventives against that habitual costiveness common to dogs and all other carnivorous animals : such, therefore, as are flesh-fed should have this tendency obviated by laxatives; and the best which offers itself is a portion of vegetable matter with their flesh food: potatoes, or even greens, can always be procured, and will answer the purpose. This is the more necessary, for costiveness sometimes occasions fatal obstructions; and a costive habit brings on fistulæ, and also affords encouragement to the breeding of worms. Medicinal laxatives are nu- 
merous. Epsom salts-sulphate of magnesia-dose one drachm to two; castor oil, two drachms to four; syrup of buckthorn, the same quantity, will either of them answer this end, the quantities being increased if those mentioned are not found sufficient : but as these directions are intended to meet the tender pet of the drawing-room, as well as the strong inhabitant of the kennel, so it is prudent to specify the minor dose : more may be added, but it is too late to subtract when too much has been given.

"Purgatives may be made by increasing the doses of any of the laxatives. Jalap is not a bad purgative to dogs, but it is uncertain, some being little affected by it; rhubarb is equally so; senna I have no experience of; gamboge is very drastic; calomel is an excellent auxiliary to other purgatives on some occasions; but given alone it is apt to deceive, by proving more emetic than purgative; neither will the stomach or bowels bear a sufficient quantity without producing much derangement in the system, as violent vomiting, tenesmus, and sometimes sudden salivation. Aloes form the safest general purge to dogs; and such are the peculiarities of the canine bowels, that while a man can take with impunity as much calomel as would kill two large dogs, a moderate-sized dog will take a quantity of aloes sufficient to destroy two stout men. The smallest dog can take fifteen or twenty grains; half a drachm is seldom too much, but the smaller dose had better be tried first: medium-sized dogs usually require a drachm, and some large dogs have taken more than two drachms: I have given three to a strong Newfoundland dog without extreme catharsis; but as before observed, dogs differ much in their different habits, and it is therefore most prudent to begin with a dose too small than too large : hundreds of dogs are every year destroyed by temerity in this particular. Whenever a purgative is administered, let the dog have some vegetable food, if possible, a day or two previously; an active cathartic, given soon after a full meal of flesh or bones, might destroy by hurrying the undigested food into the intestines, where it might form such an impacted and 
obstructing mass as could not be overcome: it is prudent to place before the dog some broth, milk, \&c., to assist purgation. Let me warn sportsmen who are putting their dogs through a course of physic, for hunting o: coursing purposes, to be aware, that it is not the inordinate strength of the dose which does good; on the contrary, violent physic often defeats its own purpose : it is a mild and repeated emptying of the bowels which unloads the system at large, and at once strengthens the solids and purifies the fluids."

This, I believe, is all that need be said, in this place, with regard to general medical treatment, except in cases of specific disease, where the aid of a medical assistant of some kind would of course be called in; and directions for the treatment of which cannot be contained within the compass of such a work as this. In consequence, however, of the great prevalence of two or three maladies, as canine distemper, worms, mange, and the like, with some common injuries arising from local accidents, I shall here add a few short recipes for the treatment of these troublesome maladies, which will be, I think, sufficient. to guide the sportsman in any ordinary cases.

Occasional bleeding is of great benefit to dogs. It is most readily performed by holding the head of the animal up, passing a ligature round the lower part of the neck, which will cause the jugular vein to swell at about one inch from the windpipe, and then puncturing the vein with a common thumb lancet. The only care necessary is to avoid inserting the lancet so deeply as to sever the vein. If the hair is thick and long, it may be requisite to clip, or even shave the spot, before effecting the orifice. No pin or ligature is necessary to close the wound. In case of fits, or any sudden emergency, a clip in the ear, if no lincet is at hand, will answer the end.

The quantity of blood to be drawn from a dog will vary according to the size of the animal, from one or two oz. in a very small dog, to six, seven, or eight in a very large one, proportionably to the nature of disease, and the violence of the symptoms. 
The pulse of the dog may be felt at the heart, and at the inner side of the protuberance of the knee. The range of pulsation between a very large and a very small dog, is not less thian 20. Thus, if 100 be taken as the usual number for the former, and 120 for the latter, whatever is found much to exceed this may be ascribed to the inflammatory state.

The following brief rules for the treatment of a few of the most common diseases, and injuries to which dogs are liable, are from Messrs. Blaine and Youatt. They are all safe, and will, I think, be found sure.

\section{DISTEMPER, OR SPECIFIC CATARRHAL DISEASE.}

The term of distemper, though in itself a very absurd and indefinite term, has become so conventional that it cannot readily be dispensed with, as by this name and no other it is generally known.

Whatever it might have been in the first instance, it is now a constitutional canine endemic, from which few individuals . escape. It is at times epidemical also, and is then peculiarly fatal. It greatly varies in form, and, particularly when it assumes the shape of an epidemic, has some peculiar characteristic type, sometimes tending to diarrhœa, sometimes to epilepsy and spasms, and sometimes, the most fatal of all, to a putrid habit.

It is unquestionably contagious, but it is, as I have stated, endemical and epidemical also, and it is also self-generated. It affects dogs at all ages, from mere puppies of five or six weeks, to adults of as many years. It occurs also many times in the same individual, and dogs have been known to escape it thrice and perish by a fourth attack. This is, however, fortunately, uncommon. In the most highly-bred dogs it is the most fatal, and I have generally observed it to be especially dangerous to the smooth-haired races, as Greyhounds and Bull-terriers. With Newfoundland dogs, at times, it makes sad havoc. Its symptoms are so various, that it is not easy to set before the reader 
any distinct or strict diagnostic signs, yet it is not difficult, on the whole, of detection.

A dry, husky cough, followed by a loss of spirits and appetite, the staring of the coat, and a thin watery discharge from the nostrils and eyes, gradually instead of limpid becoming muco-purulent, are usually the earliest symptoms of the disease; though at times the discharge does not appear, or is quickly arrested, and followed by convulsions, which usually terminate the affair very quickly.

When the symptomatic epilepsy of distemper occurs, if the attack can be arrested with the occurrence of a single fit, the dog often recovers, but if one is followed by a second, the case is usually hopeless.

The virulent or putrid type of the disease marked by a bloody and fotid discharge from the nose, eyes, and sometimes even from the ears, and by bloody, mucous and bilious evacuations of the bowels, is, I think, so almost invariably fatal, that the most merciful method is at once to destroy the animal, as an act of kindness to himself, as well as a means of preventing extended ravages by contagion.

Again, distemper often leaves behind it a species of paralysis, with nervous twitchings of the limbs, similar to chorea or St. Vitus' dance, which continually increase, until it ends in convulsions and death, though it will at times slowly and entirely disappear.

The treatment of distemper must therefore necessarily vary greatly, and it is needless to add that although almost every sportsman and breeder has, what he believes, an infallible remedy-there is no such thing as a general specific for its cure or prevention.

The best plan generally is to commence operations with a mild purgative or emetic, such as have been prescribed under the head of General Treatment.

If there is very much cough, or the pulse be very greatly excited, bleed from three to six oz., according to the age and size of the dog. If bleeding is adopted, use a very mild purgative. 
The best emetic is

Calomel, . . $\frac{1}{2}$ gr. Tartarized antimony, . $\frac{1}{2}$ gr. This formula is for the smallest dog. The largest may require of each 2 grains.

After the bowels are cleansed and the body thus depleted, R. Antimonial powder, 2, 3 or 4 grs. Nitrate of Potash, 5, 10 or 15 grs. Powdered ipecacuanha, 2, 3 or $4 \mathrm{grs}$.

Make into a ball, according to size and age, and give twice or thrice a day, as the symptoms are more or less urgent, diminishing the dose if it produces sickness.

If the cough is very distressing, add to each dose

Foxglove digitalis, $\frac{1}{2}$ to $1 \mathrm{gr}$.

If no farther symptoms occur, repeat the emetic every third or fourth day, and keep the bowels open, but strenuously avoid any thing like active purgation.

In case of diarrhœa supervening,

B. No. 1.-Powdered opium, 5 grs. $\quad$ Powdered catechu, . 2 drs. Powdered Gum-Arabic, 2 drs. Prepaled chalk. . . 2 drs. Powdered ginger, $\frac{1}{2} \mathrm{dr}$.

Make into twelve, nine, or six balls, with conserve of roses, and give from once to four times a day, pro re nata.

If this does not suffice,

R. No. 3.-Magnesia, - 1 dr. Powdered alum, $\quad 2$ scr.

Powdered calumba, $\quad 1$ dr. $\quad$ Powdered Gum-Arabic, 2 drs.

Mix with six ounces of boiled starch, and give a desert or a tablespoonful every four, six or eight hours. $p . r . n$.

In case of epileptic fits being foreseen, by sudden restlessness, animation, brightness of the eyes, and convulsive twitchings of the face and jaws, give a brisk emetic, followed by a brisk purgative, and insert a seton in the neck, the tape smeared with blistering ointment. If repeated attacks succeed, give the following formula to a medium-sized dog, half the quantity to a small one, in a spoonful of ale every two hours.

B. Aither,
Camphor, $\quad$ - $\quad 6$ gr. $\quad \begin{aligned} & \text { Tincture of opium, } \\ & \text { Spirits of hartshorn, }\end{aligned} \quad \begin{aligned} & \frac{1}{2} \mathrm{dr} . \\ & 1 \mathrm{dr} .\end{aligned}$

Place the dog in a very warm bath for twenty minutes, and keep him warm and moist by wrapping in wet flannel before the 
fire, for several hours afterward. Give nourishing food, an $l$ keep quiet.

If chorea or paralysis follow distemper, use the seton as above, stimulate the spine by rubbing the whole course of it with tincture of cantharides, and as a tonic

B. Nitrate of silver, very fine, 3 grs. Carbonate of iron, powdered, 2 drs. Gentian, powdered, 3 drs.

Conserve of roses sufficient to make six, nine, or twelve balls, of which give one every night and morning, if the stomach will bear them.

Frictions, liberal feeding, strong soups, and cold baths, may aid in this stage of the disorder.

These directions are abridged from Blaine and Youatt, and contain, I believe, the best remedial course that can be used.

For the disease under its ordinary type, the practice above detailed will be found all-sufficient, and even when diarrhøa sets in, there is no occasion to despair.

I must say, however, that although I have thought it advisable to insert formulæ for the treatment of the epileptic fits, and of the chorea or paralysis of distemper, I have never seen the fits conquered where two or three have occurred, and the chorea never.

When paralysis or chorea follows, I would myself kill the animal as an act of mercy. For the putrid or malignant type of this disease, I have not thought it worth the while to prescribe any treatment, as it is all but incurable.

\section{WORMS.}

For worms, an ailment to which dogs are extremely liable, and which is very troublesome, and at times, even dangerous, the following formula is safe and unexceptionable.

R. Cowhage-Dolichos pruriens, half a drachm. Tin-filings, very fine, 4 drachms.

made into four, six, or eight balls, with lard, according to the size of the patient, exhibit one every morning, and afterwards administer a purgative, such as epsom salts, or castor oil, or a 
very slight mercurial dose, not exceeding 4 grs. of calomel in combination with aloes.

\section{POISONS.}

For any mercurial poisons, the best remedy is the white of eggs, beaten into a liquid, given in large quantities, and repeated as often as they have been ejected. Mild clysters may be thrown up, and when the stomach is appeased, give an opiate and castor oil. When eggs are not at hand, large doses of soap dissolved in water may be tried.

For arsenic, large doses of sugar dissolved in milk, until the stomach is supposed to be cleared, then as above.

For verdigris, as for mercurial poisons.

For lead, give a strong dose of epsom salts. If this be reject ed, a ball with calomel, aloes and a quarter of a grain of opium. After this the body to be kept open with castor oil.

For vegetable poisons, a strong emetic should be given as quickly as possible, followed by a large teaspoonful of mustard, or any other strong, spicy stimulant, such as pepper, or the like, mixed with vinegar.

MANGE.

For common Mange, the following formula for ointment will be found useful:

No. 1.-Powdered sulphur, $\quad 4 \mathrm{cz}$. Muriate of ammonia, powdered, $\frac{1}{2} \mathrm{oz}$. Aloes, powdered, . $1 \mathrm{dr}$. Venice turpentine, . $\quad \frac{1}{2}$ oz. Lard, 6 oz., mix.

No. 2.-Sulphate of zinc, $\quad 1 \mathrm{dr}$. Tobacco in powder, $\quad \frac{1}{2} \mathrm{oz}$. White Hellebore in powder, $\frac{1}{2} \mathrm{oz}$. Sulphur in powder, . $4 \mathrm{oz}$. Aloes in powder, . $2 \mathrm{dr}$. Lard, . . 6 oz., mix.

No. 3.-Powdered charcoal, 2 oz. $\quad$ Powdered sulphur, $4 \mathrm{oz}$. Potash, . . $1 \mathrm{dr}$. Lard, . . $6 \mathrm{oz}$. Venice turpentine, $\frac{1}{2}$ oz., mix.

No.4.-Sulphuric acid, . 1 dr. Lard, . . . 6 o7. Tar, . $2 \mathrm{oz} . \quad$ Powdered lime, $1 \mathrm{oz}$. No. 5.--Wash.-Decoction of tobacco, $3 \mathrm{oz}$. Decoction of white hellebore, $3 \mathrm{oz}$. Oxymuriate of quicksilver, 5 grs.

With all these applications a fine wire muzzle must be used to prevent the dog licking himself, as if he do so he will infalli- 
bly perish from the strong poisonous properties of the remedies. For red mange, to any of the formula, 1, 2, or 3 , to $6 \mathrm{oz}$. of the ointments prescribed, add $1 \mathrm{oz}$. mild mercurial ointment. Use the wire muzzle as above.

In addition to these outer applications, give mild doses of epsom salts twice or thrice a weck; and occasionally, but for red mange always, the following formula:

Black sulphuret of quicksilver, Ethiop's mineral, $1 \mathrm{oz}$.

Supertartarate of potash, $1 \mathrm{oz}$. Nitrate of Potash, . $2 \mathrm{drs}$.

Divide into sixteen, twenty, or twenty-four doses, according to the size of the dog, and give one morning and evening.

Keep the dog warm and dry, and feed on vegetable diet.

\section{OPHTHALMIA,}

Whether arising from cold, or external irritation, as scratches, thorn-wounds, or the like, may be treated successfully as follows :

Give gentle purgatives, feed low; if much inflammation, bleed. Apply the following wash several times a day, after fomenting, with an infusion of poppy-heads, or a weak infusion of opium in hot water.

Superacetate of lead, $\quad \frac{1}{2} \mathrm{dr}$. Rose-water, $\quad 6$ oz. When the inflammation is disappearing,

Sulphate of zinc, $\quad 1$ scrup. Weak infusion of elm bark, 6 oz. Brandy, one teaspoonful.

\section{SORE FEET.}

"When dog's feet become sore by travelling it is common to wash them with brine, but this is not altogether a good practice. It is better to bathe them with greasy pot liquor, milk or buttermilk, and afterwards to defend them from stones or dirt by wrapping them up."-Blaine.

My practice is always after shooting, to bathe a dog's feet when unwounded, with brine, which tends greatly to indurate and prevent them from becoming sore. If actually sore, I fo]low Mr. Blaine's course of treatment. 
The habit of worming dogs is, I believe, now entirely out of date, as it is entirely useless as a preventive for hydrophobia, of which it was ignorantly supposed to prevent the possible occurrence. It is an absurd, useless and cruel practice.

I do not approve of the practice of either cropping, rounding or tailing dogs; but if in compliance with an absurd fashion it must be done, and the animal disfigured, and often seriously injured-for deafness is a common consequence of croppingthe operation should be performed with a pair of sharp, strong scissors, and a ligature should be applied to the tail, in order to prevent excessive bleeding.

For the bites of poisonous reptiles, the best remedy is to rub the part bitten freely with volatile alcali, and to give to a large dog forty drops of spirits of hartshorn hourly in a teaspoonful of sweet oil.

When these cannot be obtained, rub the wound freely with olive oil, close to a wood fire, and give large doses of olive oil internally.

A poultice of the leaves of the broad-leaved plantain, bruised and nixed with common salt, I have found useful.

For sprains, bruises or thorn wounds, hot fomentations of infusion of camomile flowers, or vinegar and water, as hot as can be endured, and warm poultices, are the best practice. In the case of thorn wounds the laceration should be carefully searched that no portion of the thorn or splinter remain within it.

Large cuts or lacerations should be washed carefully with tepid water, the lips, if necessary, secured by a stitch or two, and the edges brought into contact by strips of adhesive plaster. It is a very false idea that the animal's tongue is the best dressing. Mr. Blaine observes on this point, "In some instances, I am certain, no application can be worse to a wounded dog than his own tongue. Whenever dogs are at all inclined to foulness, as a tendency to cuticular complaint is called, a sore so licked, is sure to become mangy, and to be aggravated by the licking."

I shall conclude this branch of my subject, as I commenced 
it, by recommending it strongly to every sportsman to have always at hand, as better than the best farriers, Blaine's Canine Pathology, and Youatt on the Dog: these, if he have ordinary intelligence, and ordinary care, aided by a small medicine-chest, and a lancet-without which latter article no sportsman should ever take the field—will enable him to guard against the occurrence of most disorders in his kennel, and to conquer such as do occur, unless extraordinarily obstinate or malignant.

\section{FIELD MANAGEMENT OF DOGS.}

It is not, of course, presumed that the sportsman is necessarily to become a dog-breaker, much less that a tyro at field sports can be made a dog-breaker by reading a few pages more or less of written or printed instructions.

On the contrary, it is notorious that scarce any science is more difficult of attainment, or requires more combinations of personal qualifications than that of subduing and breaking animals. Extreme patience, great steadiness of temper, sagacity, intelligence, quickness of comprehension, firmness and even severity, must be united to long experience, to personal strength, physical courage, the power of enduring fatigue, unwearied industry, indomitable energy, and constant perseverance. Even of professional dog-breakers, not one in fifty is really up to his business; how then shall the amateur hope to jump at the conclusion in a minute.

Again, it is presumed that every person who is not a most perfect and accomplished sportsman, will buy a well-broke dog; or if he breeds, which is troublesome, and very likely to lead to disappointment, will have his Pointer or Setter trained by a professional workman.

It is true that a dog will certainly work better for the person who has first trained, and continually practised him, without ever changing his master; but so few men have the ability, and so few of those who have, are willing to give the time or labor necessary to indoctrinate a dog thoroughly, that it is hardly ever 
done by the gentleman sportsman, and indeed I should hardly recommend the attempt.

For a novice to attempt it, would be an act of stark madness. Still, however, it is necessary to know something of the theory of the science, otherwise it will be impossible to keep the animal, after being thoroughly trained, perfect in his practice; and again, it is well that the rules should be laid down distinctly, as very many professed breakers fail in their art firom want not of perseverance, but of knowledge.

First of all, it must be remembered, that although to point was once a taught quality, it is now, in the pure ligh-bred Pointer and Setter an inherited, if not natural, instinct, and in the very purest caste of Pointers to back the point of their fellows, is also now hereditary. I have seen half-a-dozen Pointer puppies, not above six weeks old, crawling about the yard, pointing the Pigeons and fowls, and backing one another, as steadily as old dogs in the field; and I hardly consider any dog, Pointer or Setter, as worth the trouble and expense of breaking, unless he points the first game bird he ever scents, even if he have not seen it.

The first step I therefore would take with a young dog, is to find out whether he has got a nose or not, and whether he is worth breaking; this I should do by taking a walk with him, and without a gun, where game abounded, and observing his actions and movements. If he have a good nose, and be highly bred, he will undoubtedly point on the first occasion of his crossing the scent of Quail, Grouse, Snipe, or Woodcock.

This point once established, the sooner he is carried home the better, and he is, on no account whatever, to be taken out again, or to see game again, until he is perfectly house-broke.

It is to the vicious plan of attempting to break dogs in the field, and in the face of game, that the number of wild, worthless, irreclaimable brutes, is to be attributed.

The first step in breaking, is to teach the dog to "down," or "charge," wherever he is. He is taught to do this in the commencement, by means of a cord fastened to his collar, and by 
gentle force, and gentle punishment-at first, at the word " down," or " charge," then by the raised hand accompanying the word; then by the raised hand alone.

This done, the cord must be removed, and he must be accustomed to "charge" at any distance from his master, and to lie steadily at charge, even although the master walks away from him with his back turned, and goes out of sight of hiim, unless he is desired to " hold up."

Lastly, he must be taught to consider the sound of the gun as equivalent to the raised hand, or the word "charge," and to obey any one of these signals when at the top of his speed.

Next, he must learn to answer the sound of the whistle, according to his master's teaching. The best signal is to turn and look at one sharp whistle, to come in at a prolonged blast. On turning his head, he is to follow the wafture of his master's hand to the right or left, and he is then to be instructed in breaking and quartering his ground regularly and evenly at the whistle, and the waive of the hand. Gradually he will come to understand the object of this teaching, and will quarter his ground alone.

This is a very important part of breaking, for no dog can be regarded as at all perfect, which only runs about its ground irregularly, without settled and orderly method, leaving great spaces uncrossed, and, perhaps, crossing other spaces several times over, wasting time thus, and failing to find much of its game; and yet it is not unfair to say, that of fifty dogs turned out as broken dogs by American breakers, not one has ever been instructed in the rudiments of this branch.

As soon as the pup drops to shot perfectly, and steadily, and turns quickly to the whistle and call, having learned the necessity of prompt and implicit obedience, and the certainty of punishment in case of wilfulness, he may be taken out alone, without a gun, to find game. He must thus be accustomed to the word "Toho," as the signal of pointing, and that so thoroughly, that he shall obey the word "Toho," by pointing steadily when there is no game. 
This done, several young dogs may be taken out to exercise together, and taught all to drop at once at the word "charge," the raised hand, or the shot; and all to stop or point simultaneously at the word "Toho," and at the sight thereafter, by each of the other's point.

All that is requisite in order to enforce these lessons, is steadiness.

The dogs must now be broke to fetch, and this is the hardest lesson of all; but no dog is perfect until he has learned it; for it is, in the first place, almost indispensable to making large bags in our wild wooded country, that dogs should fetch; and, secondly, it tends, if properly done, to render dogs deliberate and steady beyond all means in the world.

This, like the "down-charge," must, in the first instance, be taught in the collar and cord, and under the whip.

Observe, above ali things in dog breaking, that a dog is never to be taught anything by coaxing, but always by the fear of punishment. A dog which is taught by coaxing, if he turn sulky, can never be controlled, as he does not know what punishment means.

A dog is taught to fetch by charging him, putting a ball or some soft substance into his mouth, closing his jaws on it, and replacing it, with gentle punishment, so often as he rejects it. This learned, he is forced by a repetition of the same process, to rise and carry it about-then to fetch it when dropped, or thrown, till he is perfect.

Thereafter, he is made to down-charge first of all, when it is thrown, and not to attempt to fetch it, unless desired to " fetch," to drop several times to the "charge," before reaching the ball, after being sent for it, and, lastly, to "charge" with his nose almost touching it. The final lesson of all is to deliver it quietly and willingly.

All this is to be enforced by the whip, rigorously, but temperately, -invariably, but never angrily, - with praise and caresses when he does well, and reproaches accompanying chastisement. All these things he must be accustomed to do, until they have 
become ahsolutely his second nature, without his conceiving to what the teaching is applicable. This accomplished, when he never fails of obeying these signals and orders-when he becomes thoroughly aware that the least infringement of commands is followed by sure infliction of the lash-when he performs the whole routine of his little instructions, with the mechanical steadiness and coolness of a circus horse, take him out with the gun alone, and you will have no difficulty in controlling him,- -he will rapidly come to apply his theory to practice-he will become passionately and devotedly fond of his sport,- - his enthusiasm and ardor will increase the more, the more game is killed over himi, while he will keep cool and obedient with little or no trouble.

He will not associate his ideas of punishment with the game or the gun, but with the infringement of the old teachings, and he will in a very short time become-what he never would be if taken out half broke, and allowed to contract bad habits, and to commit faults before he knows that they are faults-perfect. In this case the prevention comes before the commission of the fault, and the error itself is checked by a word before it is committed. In another word, the dog is not flogged for flushing his bird, or failing to back his comrade, but for refusing obedience to the word "toho"- not flogged for running in to bite a bird, but for disobeying the word "charge," the raised hand, or the sound of the shot.

If you wait till the temptation of eagerness and impetuosity in the field, is added to the natural difficulty of teaching, you will toil in vain. No dog can ever be made a perfect dog, who is not perfectly broke to " down-charge," to " toho," to " fetch," and to obey implicitly, before a bird is killed over him.

This is the shibboleth, the grand arcanum of dog breaking.

All the rest is mere practice and experience, which make perfect both the teacher and the taught.

Young dogs should always be hunted alone, or with other young dogs. But it is far better to hunt them quite alone, until such time as they come to understand their work thoroughly, and to feel confidence in themselves 
If hunted with knowing old dogs, puppies will soon come to depend on them entirely; will follow them, and watch their every motion, and never learning to beat their own ground, or find their own game, will content themselves with backing, instead of pointing, and will become timid, and ultimately useless.

Hunting puppies, on the contrary, together, will tend to make them all wild and rash, and to induce their mutually learning the faults of all.

On the whole, therefore, it is the better way to hunt young dogs singly during their first season, killing as many birds over them as possible; and, at the beginning of the second year, remembering that brace-hunting is the proper sphere of Pointers, or Setters, to introduce them to mates of their own ages, and thenceforth always to hunt, and, as much as you can, feed the same braces together. One brace of dogs, accustomed so to live and beat together, will do better work a-field, than three dogs of equal qualities, all working each " on his own hook."

So much for the rules of dog breaking !

With regard to practice and management in the field, there is little or nothing to be said, beyond what I have already laid down, passim, under the heads of the various kinds of Upland shooting.

Dogs should not be harassed by too many, and never by contrary, orders. No fault should ever be passed over in silence, and very few will be committed. Punishment should be inflicted as rarely as possible, but when it is inflicted, it should be done thoroughly and severely.

Never holloa at a dog-never run after a dog, but either make him come back to you, or bide your time till he becomes tired and returns of his own accord, then punish for the double event.

When you enter a field, or covert, which you propose to beat, bid your dogs " hold up," and waive them right and left. Turn them by a whistle, and waive them hither or thither. When they strike a bevy of Quail, or other game, never hurry after them, but make them go slow by the word "steady." If they are rash, be you deliberate. If you hurry on, you best encow 
rage their hurrying. Never mind if they flush one bevy, and you lose one shot. Be steady, and punish, so that they will not do so again.

When they point, flush your own bird, even if you get a worse shot at it than you would do by hieing on your dog. To do so will make him heedless and headstrong.

If you kill, stand still, cry "down-charge," and load your gun. If the dogs run in, don't run after them, it will only make them run the faster. Stand still, and cry " down," till you have done loading. Then go on deliberately, never heed the dead bird, which is probably half eaten by this time, but drag the offender back to the place whence he started, crying "downcharge," and lashing him all the way,-then hold him down, and flog him most severely. Make him lie still, without stirring, till you have brought the bird, and laid it close under his nose. Then make him pick it up, and give it you,- - he will not run in many times, if so dealt withal.

Break your dogs thus, or have them thus broken, and when they are broken, handle them thus in the kennel, and in the field, and my word on it, they will be, and continue good ones.

I am induced, by some experiments, to qualify my opinions, as expressed on page 340 , in relation to the use of Indian meal as dog food, so far as to observe that the meal must be old, since, if new, it is too laxative. Where oat-meal can be procured, I incline to the belief that the mixture of it with Indian meal, in equal proportions, will be found the best possible dog food.

END OF VOLUME ONE. 




UNIVERSITY OF ILLINOIS-URBANA 